\title{
INTERAÇÃO GENÓTIPOS X AMBIENTES EM TOPOCRUZAMENTOS DE SOJA TIPO ALIMENTO COM TIPO GRẼO
}

\section{GILBERTO KEN-ITI YOKOMIZO}

Engenheiro Agrônomo

Orientador: Prof. Dr. NATAL ANTONIO VELLO

Tese apresentada à Escola Superior de Agricultura "Luiz de Queiroz", Universidade de São Paulo, para obtenção do título de Doutor em Agronomia, Área de Concentração: Genética e Melhoramento de Plantas.

P I R A C I C A B A

Estado de São Paulo - Brasil

Março - 1999 
YOKOMIZO, G.K. Interação genótipos x ambientes em topocruzamentos de soja tipo alimento com tipo grão, 1999, 170p.

\section{ERRATA}

\begin{tabular}{|c|c|c|c|}
\hline Página & Linha & Onde se lê & Leia-se \\
\hline Índice & 17 & 2.7. Interação Genótipo x Ambiente... & 2.7. Interação Genótipos $x$ Ambientes... \\
\hline 59 & 14 & ...somas de quadrados das progênies e... & ...somas de quadrados das progênies... \\
\hline 95 & 15 & ...no grupo das;,.. & ...no grupo das testemunhas; $\ldots$ \\
\hline 102 & 25 & As Tabelas 27 e 28 .. & As Tabelas 29 e $30 \ldots$ \\
\hline 110 & 06 & $\begin{array}{l}\text {...as progênies } 10,16,17 \text { e } 22 \\
\text { consideradas... }\end{array}$ & ...várias progênies consideradas... \\
\hline 110 & 10 & $\begin{array}{l}\text {...Figura 1; porém estas progênies }(4 \text {, } \\
\quad 7 \text { e 12)... }\end{array}$ & $\begin{array}{l}\text {...Figura } 1 \text {. As progênies } 1,8 \text { e } 20 \text { para } \mathrm{PG} \text { e } \\
\text { a progênie } 5 \text { para VA... }\end{array}$ \\
\hline Página & \multicolumn{3}{|c|}{ Acrescenta-se } \\
\hline 119 & \multicolumn{3}{|c|}{$\begin{array}{l}\text { CHAUDARY, D. N. \& SINGH, B. B. Heterosis in Soybean. Indian Journal of Genetics } \\
\text { and Plant Breeding, v.34, n.1, p.69-74, } 1974 \text {. }\end{array}$} \\
\hline 120 & & \multicolumn{2}{|c|}{$\begin{array}{l}\text { DESTRO, D; SEDIYAMA, T.; SILVA, J. C.; SEDIYAMA, C. S.; THIÉBAUT, J. T. L. } \\
\text { Estimativas de herdabilidade de alguns caracteres em dois cruzamentos de soja. } \\
\text { Pesquisa Agropecuária Brasileira, v.22, n.3, p.291-304, } 1987 .\end{array}$} \\
\hline
\end{tabular}




\title{
Dados Internacionais de Catalogação na Publicação (CIP) DIVISÃo DE BIBLIOTECA E DOCUMENTAÇÃO - Campus "Luiz de Queiroz"/USP
}

\author{
Yokomizo, Gilberto Ken-Iti \\ Interação genótipos $\mathrm{x}$ ambientes em topocruzamentos de soja tipo alimento \\ com tipo grão / Gilberto Ken-lti Yokomizo. - - Piracicaba, 1999. \\ $170 \mathrm{p}$. \\ Tese (doutorado) - Escola Superior de Agricultura Luiz de Queiroz, 1999. \\ Bibliografia.
}

1. Alimento vegetal 2. Cruzamento vegetal 3. Genética e melhoramento vegetal 4 . Germoplasma vegetal 5 . Interação genótipo-ambiente 6 . Soja I. Título

CDD 633.34

Mermitida a copta total ou parcial deste focomento desde que eifada a fonte 0 antor 
À minha familia, representada pelos meus pais..

Que me ofereceu condições para crescer

\author{
Dedico...
}

À minha querida companheira, Eidy Simões de Souza, Que me estimulou nos momentos dificeis desta tese,

Ofereço 


\section{AGRADECIMENTOS}

-A Deus por ter me dado condições e força para atingir este objetivo.

-Ao Professor Dr. Natal Antonio Vello, pela orientação e amizade, oferecendo a possibilidade de efetivação dessa pesquisa.

-A EMBRAPA-CNPAF/AP por ter permitido o término desta tese.

-Ao Conselho Nacional de Desenvolvimento Científico e Tecnológico (CNPq), à Fundação de Amparo à Pesquisa do Estado de São Paulo (FAPESP), à EMBRAPA pelos apoios relevantes às pesquisas do Setor de Genética Aplicado às Espécies Autógamas, Departamento de Genética/ESALQ/USP, entre as quais se inclui este trabalho.

-À FAPESP pela bolsa de Iniciação Científica e ao CNPq pelas bolsas de mestrado e doutorado, que possibilitaram a realização dos cursos de pós-graduação pelo autor.

-Aos Professores do Departamento de Genética da ESALQ, pelos ensinamentos e atenção dispensada no decorrer do curso.

-Aos amigos, Luciana de Andrea Ribeiro e Claudio Yuji Tsutsumi, pela amizade e apoio fundamental nos trabalhos de laboratório.

-Aos amigos, Joaquim Adelino de Azevedo Filho, Nelson da Silva Fonseca Júnior e Júlio S. Bueno, pelas sugestões e correções do texto da tese.

-Ao amigo, Nelson da Silva Fonseca Júnior pela amizade e auxilio nas análises estatísticas, pelas informações prestadas e principalmente pela paciência manifestada.

-Ao amigo, Marcos Custódio Nekatschalow e família, pelo apoio, pela amizade e paciência. 
-Aos amigos, em especial, pela convivência em todos os momentos: Luciana de Andrea Ribeiro, Érica E. Baron, Solange R. M. Andrade, Chirlei Glienke, Ana Claudia C. Badan, Tamara C. Fonseca, Antonio Ismael I. Cardoso, Luis C. Prado, Leonardo N. Rosse, Rhainer G. Cardoso, Alvis H. Adames e José Raolindo Gardingo,

-A todos os demais colegas de curso, um especial agradecimento, pela amizade que jamais esquecerei, pelo convívio fantasticamente agradável e pelas práticas esportivas.

-Aos amigos, do grupo da soja: Ângela C. A. Lopes, Claudio Y. Tsutsumi, Dario M. Hiromoto, Diego O. Soldini, Edna R. Moresco, Fabio Pandini, Fernando T. S. Miranda, Jorge R. Laínez Mejía, Jose B. Pinheiro, Sandra Helena U. Trevisoli, Maurisrael M. Rocha, Leandro C. Teixeira, pelo convívio e amizade.

-Aos funcionários, Antônio Roberto Cogo, Claudinei Antônio Didoné, um agradecimento exclusivo pelos apoios nas etapas de campo e laboratório e pela amizade.

-A todos os funcionários do Departamento de Genética e do setor de Pós Graduação da ESALQ, pela amizade e atenção gentilmente cedida.

-Às bibliotecárias Silvana Marchizelli Gregório e Aparecida Elizabeth do Santos da Silva pelos seus gentis préstimos no decorrer do curso.

-A todos que de uma forma ou outra tenha contribuído para essa tese, e que por injustiça eu tenha esquecido de agradecer. 


\section{ÍNDICE}

1. INTRODUÇÃO

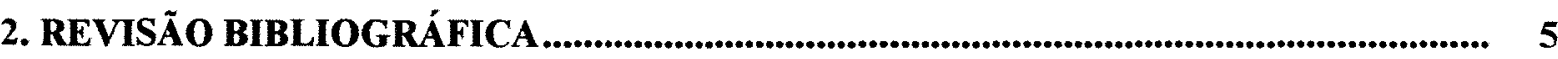

2.1. Soja na alimentação ..................................................................................................... 5

2.2. Problemas relacionados à soja para alimentação ........................................................ 8

2.3. Substâncias antinutricionais............................................................................................. 12

2.4 Composição química de sementes de soja .................................................................... 13

2.5. Herança de caracteres ........................................................................................................ 13

2.5.1. Período Juvenil e tolerância ao fotoperído ...................................................................... 13

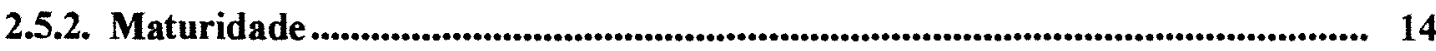

2.5.3. Produtividade, altura da planta e valor agronômico............................................. 15

2.5.4 Tamanho de semente e largura das vagens............................................................ 17

2.5.5. Comparação das estimativas de variabilidade ...................................................... 20

2.6. Correlação entre caracteres ........................................................................................... 20

2.6.1. Tamanho das sementes com tamanho das vagens ............................................... 21

2.6.2. Tamanho das sementes e outros caracteres ....................................................... 22

2.6.3. Outros caracteres ........................................................................................... 23

2.7. Interação Genótipo x Ambiente .................................................................................. 24

2.7.1. Categorias de efeitos ambientais ........................................................................ 25

2.7.2. Exemplos de caracteres que apresentam interação $G \times$ E................................... 26

2.7.3. Conhecimento fisiológico para a interação $\mathbf{G} \times$ E.................................................. 27

2.7.4. Análises estatísticas para avaliação da interação $\mathbf{G} \times \mathbf{E}$........................................ 28

2.7.5. Fatores ambientais atuando na interação G X E............................................. 32

2.7.5.1. Efeito da temperatura na interação ........................................................ 32

2.7.5.2. Efeito da época de semeadura na interação.......................................... 33

2.7.5.3. Efeito da altitude na interação ...................................................... 36

2.7.5.4. Efeito da irrigação na interação......................................................... 36

2.8. Teste de Wricke ................................................................................................................. 37

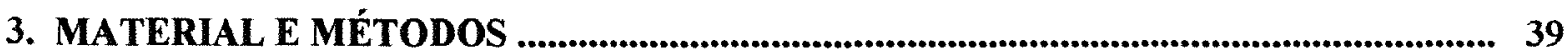

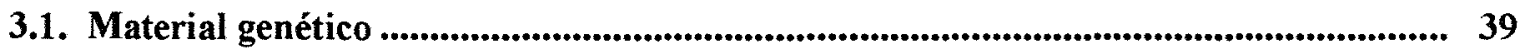

3.2. Ambiente experimental................................................................................................... 40

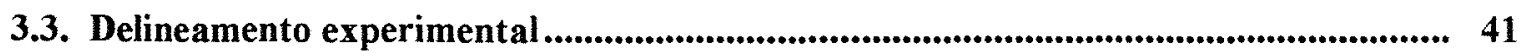

3.4. Croqui do experimento por local......................................................................................... 41

3.5. Caracteres avaliados............................................................................................. 42

3.5. Análises estatístico-genéticas .................................................................................... 43

3.5.1. Considerações iniciais......................................................................................... 43

3.5.2. Médias e variâncias .....................................................................................43

3.5.3. Análise de Variância................................................................................... 44 
3.5.4. Contribuição de cada fonte de variação na diversidade total dos dados para cada caráter

3.5.5. Desempenho médio das progênies.

3.5.6. Teste de SCOTT \& KNOTT e histograma para agrupamento dos genótipos . 47

3.5.7. Correlações genéticas e fenotípicas

3.5.8. Teste de Wricke para avaliação da contribuição de cada genótipo na interação G x E ............................................................................................ 50

3.5.9. Gráfico de caixa (Box Plot) ................................................................... 52

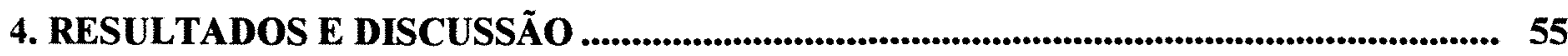

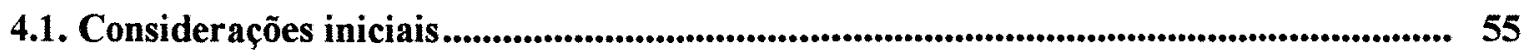

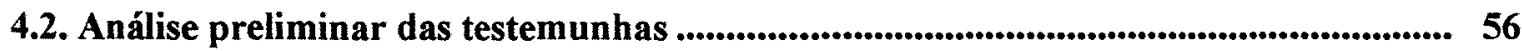

4.3. Análise de variância para os genótipos .............................................................. 57

4.3.1. Análise de variância para cada ambiente ................................................. 57

4.3.2. Análise de variância conjunta .................................................................. 58

4.4. Contribuição de cada fonte de variação na diversidade total dos dados.................... 59

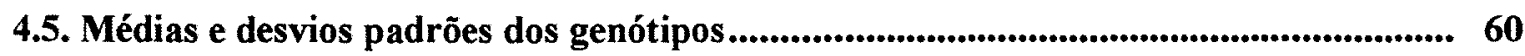

4.5.1. Largura visual das vagens................................................................................ 61

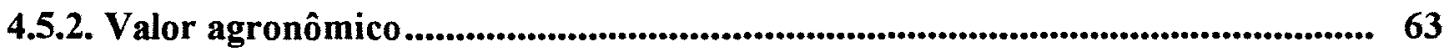

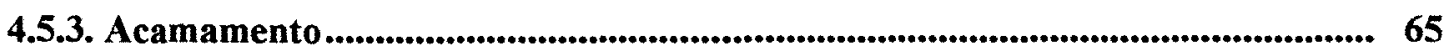

4.5.4. Número de dias para a maturidade ............................................................ 67

4.5.5. Altura da planta na maturidade ............................................................. 68

4.5.6. Produtividade de grãos ................................................................................. 71

4.5.7. Peso de cem sementes ...................................................................................... 74

4.6. Desempenho médio dos genótipos ..................................................................... 76

4.6.1. Análise individual por ambiente e em relação às médias de progênies e de testemunhas ............................................................................................. 76

4.6.2. Análise conjunta de ambientes e relações com as média de progênies e de testemunhas

4.7. Comparação de médias e agrupamento das progênies pelo teste de Scott-Knott ....... 85

4.8. Correlações fenotípicas de Pearson ........................................................................ 93

4.8.1. Para os grupos de progênies e de testemunhas ................................................ 93

4.8.2. Para as progênies individuais............................................................................. 96

4.9. Correlações genéticas .......................................................................................... 99

4.10. Avaliação da interação $G \times$ E pela ecovalência e pelo histograma ............................. 102

4.11. Interação $G \times \mathbf{E}$ pelo gráfico de caixa (Box Plot) ....................................................... 110

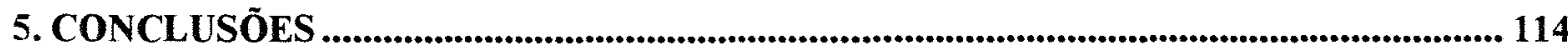

6. REFERÊNCIAS BIBLIOGRÁFICAS............................................................................... 116

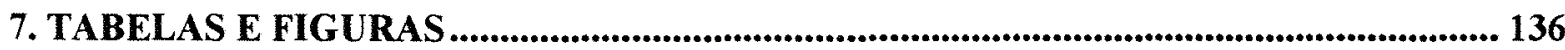

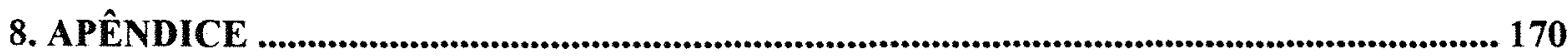




\title{
INTERAÇÃO GENÓTIPOS X AMBIENTES EM TOPOCRUZAMENTOS DE SOJA TIPO ALIMENTO COM TIPO GRÃO
}

\author{
Autor: GILBERTO KEN-ITI YOKOMIZO \\ Orientador: Prof. Dr. NATAL ANTONIO VELLO
}

\section{RESUMO}

Esta pesquisa teve como objetivo verificar o desempenho de progênies de soja (Glycine $\max (\mathrm{L}$.) Merrill) em três ambientes, avaliar o efeito da interação genótipos $\mathrm{x}$ ambientes ( $G \times \mathrm{E})$ e estimar as correlações entre caracteres visando-se facilitar etapas futuras de seleção e recomendação de novos genótipos de soja alimento com sementes grandes, para três tipos de usos: hortaliça (edamame, vagens imaturas largas, sem restrição de cor de tegumento e de hilo), doce (kuromame, sementes maduras com tegumento e hilo pretos) e salada (sementes maduras com tegumento e hilo de cor clara). Os três ambientes compreendem: a) Piracicaba-verão (PV), semeadura em 15/nov/1996; b) Piracicaba-outono (PU), semeadura em 07/mar/1997; c) Anhembi-verão (AV), semeadura em 17/nov/1996. O maior contraste entre os locais Piracicaba e Anhembi ocorre nas propriedades fisico-químicas do solo; Piracicaba tem solo tipo terra roxa estruturada; já Anhembi apresenta solo tipo aluvial distrófico arenoso semelhante aos encontrados nos cerrados brasileiros. Os materiais avaliados foram 24 progênies $F_{9: 4}$ provenientes de 15 topocruzamentos, sendo que dois topocruzamentos (Late Giant $\mathrm{x}$ Doko e Aliança Preta $x$ Doko) contribuíram com mais de uma progênie. Os três experimentos foram delineados em blocos ao acaso, com duas repetições estratificadas em conjuntos com testemunhas comuns. Cada repetição foi subdividida em dois conjuntos, contendo 12 progênies e quatro testemunhas (cultivares de soja alimento com sementes grandes). A parcela experimental foi representada por dez covas de plantas individuais espaçadas de $1,00 \mathrm{~m} \times 0,50 \mathrm{~m}$. Entre parcelas o espaçamento foi $1,00 \mathrm{~m}$. Os caracteres avaliados foram: número de dias para a maturidade (NDM); altura da planta na maturidade (APM); acamamento (AC); valor agronômico (VA); largura visual das vagens (LVV); peso de cem sementes (PCS) e produtividade de grãos (PG). Com os resultados obtidos concluiu-se que: a) Várias das progênies superiores em $F_{9: 4}$ já haviam se destacado em gerações anteriores $\left(F_{2}, F_{3: 2}\right.$ ou $\left.F_{5: 4}\right)$. b) Foram obtidas progênies 
precoces, com ciclo menor que 110 dias, mesmo em topocruzamentos com o parental tardio 'Doko'. c) Ao se realizar seleção para maior altura da planta na maturidade (APM) é obrigatório considerar junto o acamamento (AC). d) $\mathrm{O}$ ambiente favorável $\mathrm{PV}$ foi o que melhor permitiu diferenciar as progênies para os caracteres APM, LVV e PG. O ambiente estressante PU permitiu a diferenciação das progênies para todos os caracteres, exceto para $\mathrm{AC}$. $\mathrm{O}$ ambiente $\mathrm{AV}$ apresentou desempenho relativamente intermediário em discriminar as progênies. e) As correlações entre caracteres foram muito alteradas pelas variações ambientais. f) $\mathrm{O}$ gráfico de caixa evidenciou efeitos ambientais marcantes sobre os caracteres: VA, NDM, PG e APM. Já o tamanho das sementes, avaliado pelo PCS, foi pouco influenciado pelas variações ambientais. g) O método da ecovalência foi mais eficiente que o uso conjunto do teste de Scott-Knott e de histograma para medir a estabilidade das progênies. h) A seleção baseada na estabilidade medida pela ecovalência e nas médias dos caracteres relevantes para soja alimento com sementes grandes mostrou-se eficiente para obtenção de novos genótipos apropriados aos três tipos de usos: salada, doce, hortaliça. Para uso como salada, cinco progênies foram superiores: USP 98-06007, USP 98-0609, USP 98-06027, USP 98-06029 e USP 98-06031. Outras cinco progênies (USP 98-06013, USP 98-06014, USP 98-06017, USP 98-06018 e USP 98-06025) destacaram-se como soja doce. Finalmente, a seleção para soja hortaliça, além das dez progênies anteriores, incluiu mais quatro progênies (USP 98-06011, USP 98-06019, USP 98-06028 e USP 98-06032). 


\title{
GENOTYPE X ENVIRONMENT INTERACTION IN TOPCROSSES AMONG FOOD TYPE AND GRAIN TYPE SOYBEANS
}

\author{
Author: GILBERTO KEN-ITI YOKOMIZO \\ Adviser: NATAL ANTONIO VELLO
}

\section{SUMMARY}

This research aimed to verify the performance of soybean (Glycine max (L.) Merrill) progenies over three environments, to evaluate the genotype $x$ environment ( $\mathrm{G} \times \mathrm{E}$ ) interaction, and to estimate the correlation among characters. The estimates of these parameters can to facilitate the future selection steps, and the release of new food type, large-seeded genotypes for three kinds of use: vegetable soybean (edamame, imature, large-poded, without limitations on seed-coat and hilum-color); sweetmeat soybean (kuromame, mature seeds with black coat and hilum); salad soybean (mature seeds with light coat and hilum). The three environments were: a) Piracicaba-summer season (PV), sowing on November 15, 1996; b) Piracicaba-autumn season (PU), sowing on March 07, 1997; c) Anhembi-summer season (AV), sowing on November 17, 1996. The localities Piracicaba and Anhembi have as main contrast the physical-chemical properties of soils: Piracicaba has alfisol type; Anhembi presents a sandy soil, commonly found in the Brazilian savannas (cerrados) and with the acidity neutralized by using lime. There were evaluated 24 topcrossed progenies in $\mathrm{F}_{9: 4}$, derived from 15 different topcrosses; the following two topcrosses has contributed with more than one progeny: Late Giant $x$ Doko and Aliança Preta $x$ Doko. The three experiments were designed in randomized complete blocks, each one with two replications stratified in experimental sets with common checks. The replications were stratified in two sets, each one having 12 progenies and four checks (food type, large-seeded soybeans cultivars). The experimental plot was represented by ten hills of individual plant, spaced $1.00 \mathrm{~m} \times$ $0.50 \mathrm{~m}$. Between plots the space was $1.00 \mathrm{~m}$. The following characters were evaluated: number of days to maturity (NDM), plant height at maturity (APM), lodging (AC), agronomic value (VA), visual width pod (LVV), one hundred seed weight (PCS), and seed yield (PG). The results permitted the following conclusions: a) Various of the superior progenies in $F_{9: 4}$ had already exceeded in the previous generations $\left(F_{2}, F_{3: 2}\right.$ or 
$F_{5: 4}$ ). b) It was obtained early progenies having less than 110 days of cycle, despite they were originated from topcrosses with the late parental 'Doko'. c) In the selection for increase plant height at maturity (APM) it is obligatory to consider the lodging (AC) together. d) The favorable environment (PV) permitted the best differentiation among progenies for the characters APM, LVV, and PG. The stressing environment (PU) permitted the differentiation among progenies for all characters, except $\mathrm{AC}$. The Anhembi-summer environment was relatively intermediate in discriminating the progenies. e) The correlation coefficients among characters were much altered by the environmental variations. f) The "Box-plot" evidenced significative environmental effects on the characters: VA, NDM, PG and APM. However the seed size, evaluated by the one hundred seed weight (PCS), was not much influenced by the environmental variations. g) The ecovalence method was more efficient than the combined use of Scott-Knott method and histogram to measure the stability of the progenies across environments. h) The selection based on the ecovalence stability and on the means of important characters for large-seeded, food type soybeans was efficient in obtaining new genotypes for the three kinds of use: salad, sweetmeat, and vegetable. As salad soybeans were found five superior progenies: USP 98-06007, USP 98-0609, USP 98-06027, USP 98-06029, and USP 98-06031. Other five progenies (USP 98-06013, USP 98-06014, USP 98-06017, USP 98-06018, and USP 98-06025) exceeded as sweetmeat soybeans. Finally, the selection for vegetable soybeans, besides the previous mentioned ten progenies, included more four progenies (USP 98-06011, USP 98-06019, USP 9806028, and USP 98-06032). 


\section{INTRODUÇÃo}

A soja (Glycine max (L.) Merrill) pode ser didaticamente classificada em dois grupos principais: tipo grão e tipo alimento. A soja tipo grão apresenta sementes de tamanho médio, representado pelo peso de cem sementes (PCS) entre 10 e $19 \mathrm{~g}$, sendo cultivada principalmente para atender as indústrias brasileira e estrangeira de farelo e óleo. A soja tipo alimento apresenta duas categorias: a) sementes pequenas, com PCS menor que $10 \mathrm{~g}$, destinadas ao consumo em forma de brotos e de "nattô" (fermentado); b) sementes grandes, com PCS igual ou maior que $20 \mathrm{~g} / 100$ sementes. A soja com sementes grandes tem os seguintes usos principais: $b_{1}$ ) soja hortaliça (vegetable soybean, green soybean, ou edamame), utilizada para consumo humano direto na forma de vagens imaturas (fase $R_{6}$ de Fehr \& Caviness (1977)) fervidas em salmoura e os grãos consumidos como tira-gosto; $b_{2}$ ) soja doce (kuromame), compreendendo genótipos com sementes grandes, de tegumento preto e consumidos na forma de grãos maduros, geralmente cozidos no vapor e preparados como doces especiais; $b_{3}$ ) soja salada, para preparação de saladas mistas (soja misturada com hortaliças e legumes) com sementes maduras grandes e tegumento de coloração amarela, verde ou variegada.

A soja tipo alimento apresenta além do tamanho grande das sementes (PCS $\geq 20 \mathrm{~g}$ ), outras características peculiares: sabor adocicado semelhante ao de nozes, alto teor de carboidratos ausência ou menor produção de odores indesejáveis, ausência ou reduzido teor de um ou mais fatores antinutricionais (Carrão-Panizzi, 1989; Orf, 1989; Vello, 1992a). As cores do tegumento e do hilo não têm limitações para a soja tipo hortaliça, pois os grãos imaturos têm tegumentos de coloração sempre verde e a cor do hilo fica escondida dentro das vagens, não sendo visível, uma vez que a vagem é presa entre os dentes e puxada para fora, deixando os grãos no interior da boca do consumidor. 
Já para a fabricação de doces, deseja-se plantas que produzam grãos com tegumento e hilo pretos; e, para saladas, o ideal é representado pela planta que produz grãos com tegumento de cor amarela e hilo cor creme, aceitando-se em alguns locais (p.ex. na ilha principal do Japão: Honshu) grãos de cor verde ou variegada (tegumento verde ou amarelo e hilo tipo sela de cor creme ou marrom). Estas características são encontradas principalmente em genótipos originários da China e Japão; tais genótipos têm sido introduzidos no Brasil para o melhoramento da soja visando-se a alimentação humana, pois os cultivares brasileiros tipo grão têm sementes de tamanho médio (PCS entre $10 \mathrm{e}$ 19 g) e apresentam sabor amargo, adstringente, além da presença de alto teor de lipoxigenases e substâncias antinutricionais.

Um outro ponto importante a ser lembrado, refere-se aos nutrientes, à quantidade e ao custo da proteína da soja cozida. Sua proteína tem coeficiente de eficiência protéica (ganho de peso por proteína consumida) em torno de $62 \%$ em relação à carne bovina, $80 \%$ do leite e $52 \%$ do ovo. O custo para produzir a proteína de soja foi calculado em 0,35 dólares por quilograma, sendo que para se obter o mesmo quilograma para feijão o custo é de 3,50; para ovos de 5,69; leite "C" de 9,50 e carne bovina de 5,39 (Carrão-Panizzi, 1988).

Fatores como grande valor protéico ( $40 \%$ do grão inteiro), a riqueza das proteínas em aminoácidos essenciais (excetuando-se os sulfurados: metionina e cistina), as evidências recentes da capacidade da soja em prevenir e curar doenças crônicas dos seres vivos, e o seu custo de produção relativamente baixos, têm provocado um aumento no interesse de introduzir a soja como uma alternativa alimentar para suprir, ao menos parcialmente, as exigências nutricionais da população brasileira. Os alimentos derivados da soja têm surgido, sob as mais diversas formas: "in natura"; semi-cozida; extrato (tonyu, leite) de soja em líquido, ou em pó e aromatizados; proteína vegetal texturizada (PVT ou carne); processada junto a outros produtos, em embutidos, biscoitos, bolachas e sopas; queijo (tofu); molho (shoyu); grãos fermentados (nattô); pasta (missô); broto. A carência dos aminoácidos sulfurados pode ser facilmente 
contornada associando-se a soja com outros alimentos complementares, como cereais (arroz, milho e trigo como exemplos).

Apesar da grande produção brasileira (29 milhões de toneladas/ano; $2^{\mathrm{g}}$ produtor mundial, Agrianual, 1998), o mercado brasileiro consumidor de soja é bastante restrito, destinando-se a maior parte da produção às indústrias de extração de óleo e processamento de margarinas, que compõem mais de $70 \%$ do total de consumo de lipídeos dos brasileiros; já em relação ao farelo (fração protéica), destinado à alimentação animal, $30 \%$ permanece no Brasil e $70 \%$ é exportado.

Recentemente, vem surgindo no Brasil uma nova categoria de produtores de soja tipo alimento com sementes grandes para atender ao interesse brasileiro crescente de uso na alimentação humana direta e para exportação para países orientais e, também, para os Estados Unidos e a Austrália. Shanmungasundaram et al. (1989) afirma que o Japão consome 150.000 t/ano de vagens verdes tipo hortaliça, importando somente de Taiwan $50.000 \mathrm{t}$ de vagens imaturas de soja tipo hortaliça embaladas em sacos plásticos fechados a vácuo e congelados.

Devido ao fato da soja tipo alimento ter o seu cultivo restrito ao oriente (Gotoh, 1984), onde não tem participado de cruzamentos com soja tipo grão, ela é considerada como sendo genótipo exótico no ocidente. Um problema apresentado pelos genótipos exóticos é a sua inadaptabilidade às condições brasileiras, florescendo precocemente (Santos, 1988). Florescimento precoce associado com hábito de crescimento determinado, produzem plantas com porte muito baixo e, com isso, uma baixa produtividade de grãos. Outro problema dos genótipos de soja tipo alimento é a baixa qualidade fisiológica de suas sementes, causando um declínio rápido da capacidade de germinação das sementes e do vigor das plântulas. Uma possível solução é o cruzamento desses genótipos exóticos com genótipos adaptados tipo grão, tentando-se reunir em uma mesma planta os genes que conferem características favoráveis ao consumo humano direto, presentes nos genótipos exóticos, com os genes para tolerância ao fotoperíodo, alta produtividade e alta qualidade fisiológica das sementes dos genótipos adaptados. 
A avaliação da interação de genótipos com ambientes $(G \times E)$ é de grande importância, devido a possibilidade do melhor genótipo em um ambiente não apresentar o mesmo desempenho em outro. Este fato influencia o ganho com seleção, dificultando a escolha efetiva dos melhores cruzamentos, sendo necessário um método adequado de avaliação e seleção para se obter as melhores progênies (Brim, 1973). Os principais fatores ambientais que são amplamente pesquisados por sua influência no fenótipo da soja são: temperatura, época de semeadura, pluviosidade, fotoperíodo, fertilidade e toxidez do solo. Existem caracteres na soja que interagem mais fortemente com as variações ambientais, como por exemplo: produtividade de sementes, tamanho das sementes, ciclo (Gupta et al., 1982a); os conteúdos de óleo e de proteína (Xiagxun et al., 1991; Schnebly \& Fehr, 1993). Desse modo, não há como se prever o comportamento de um genótipo de soja em um ambiente desconhecido (novo). Para se contornar esse problema, realiza-se o maior número de experimentos possíveis (em função da disponibilidade de recursos, sementes, área e mão-de-obra) e emprega-se uma metodologia estatística apropriada para a análise.

A pesquisa proposta tem por objetivo principal a avaliação de progênies (geração $F_{9: 4}$ ) originadas de topocruzamentos entre parentais exóticos tipo alimento e parentais adaptados tipo grão, desenvolvidas e selecionadas pelo programa de ampliação da base genética do germoplasma e melhoramento da soja do Setor de Genética Aplicada às Espécies Autógamas, Departamento de Genética, ESALQ/USP. Pretende-se estimar o efeito da interação $\mathrm{G} \times \mathrm{E}$ sobre o desempenho destas progênies, além de parâmetros auxiliares (p. ex. correlação entre caracteres) que possam viabilizar as etapas futuras de seleção e a liberação de soja tipo alimento com sementes grandes para cultivo de novos genótipos. 


\section{REVISÃo BIBLIOGRÁFICA}

\subsection{Soja na alimentação}

A soja tem como centro de origem e domesticação a China, sendo introduzida posteriormente no Japão em tempos remotos, onde o tamanho reduzido das propriedades existentes permitiu o cultivo apenas em pequena escala. Existem grandes possibilidades da soja ter sido introduzida inicialmente apenas como uma importante erva medicinal e, posteriormente, como alimento (Gotoh, 1984).

Na China, a soja é destinada principalmente para a extração de óleo e de farelo (alimentação animal e fertilizante). Uma parte é processada para o consumo humano na forma de tofu (queijo ou coalho), molho de soja (shoyu), pasta de soja (missô), extrato (leite) de soja, ou consumida diretamente como hortaliça (Jian, 1984).

$\mathrm{Na}$ Coréia, a soja representa a terceira maior área de cultivo e de produção de grãos destinados à alimentação humana, atrás do arroz e da cevada. Produtos de soja como o missô, o shoyu, o tofu e os brotos dos grãos são alimentos básicos na dieta diária dos coreanos. Uma peculiaridade observada é o cultivo de soja com sementes grandes no Norte e os com sementes pequenas no Sul da Coréia (Hong et al., 1984).

Os cultivares de soja foram divididos por De \& Russell ${ }^{1}$ (1967) citados por Maga (1973) em três grupos básicos, baseando-se principalmente no sabor apresentado pelo grão: a) comerciais; b) forrageiras; c) hortaliças ou vegetais, sendo que os dois primeiros grupos apresentam aroma de feijão cru e o terceiro de leite ou castanha. No Brasil, Vello (1992a) classificou a soja em dois grupos de acordo com o tamanho das

\footnotetext{
${ }^{1}$ DE, S.S. \& RUSSELL, J.S. Soybean protein foods, USDA, ARS-71-35, 1967, 20p.
} 
sementes $($ Peso de Cem Sementes $=$ PCS $)$ e com o destino comercial. O primeiro grupo é denominado soja tipo grão com PCS entre 10 e $19 \mathrm{~g}$, sendo o tipo utilizado pelas industrias de óleo e farelo. O segundo grupo é o da soja tipo alimento, apresentando duas categorias: a) sementes pequenas com PCS menor que $10 \mathrm{~g}$, destinadas ao consumo em forma de brotos e de "nattô" (fermentado); b) sementes grandes com PCS igual ou maior que $20 \mathrm{~g} / 100$ sementes. A soja com sementes grandes tem os seguintes usos principais: $b_{1}$ ) soja tipo hortaliça (vegetable soybean, green soybean, ou edamame), utilizada para consumo humano direto na forma de vagens imaturas (fase $\mathrm{R}_{6}$ de Fehr \& Caviness (1977)) fervidas em salmoura e os grãos consumidos como tira-gosto; $b_{2}$ ) soja chamada "kuromame" ou tipo doce, compreendendo genótipos com sementes grandes, de tegumento preto e consumidos na forma de grãos maduros, geralmente cozidos no vapor e preparados como doces especiais; $b_{3}$ ) soja para uso em saladas mistas (soja misturada com hortaliças e legumes) com sementes maduras grandes e tegumento de coloração amarela, verde ou variegada. A soja tipo alimento possui também menores teores de lipoxigenase, ácido linolênico e saponinas.

Além do teor protéico outras características são importantes para o consumo humano, como o tamanho e a cor dos grãos. Para o processamento de missô é necessário grãos com tegumento e hilo claros, para não ocorrerem manchas no produto final; para nattô é necessário grãos pequenos, com alto teor de proteínas e tegumento e hilos claros; para consumo como hortaliça, os grãos devem ser grandes e levemente achatados. Taira (1990) cita também que o conteúdo e proporções de proteína e óleo no grão são importantes para a produção de tofu, enquanto que o sabor e a cor são importantes para a produção de missô e nattô

A soja tipo alimento apresenta algumas características peculiares, diferindo da soja tipo grão pelo maior teor de proteínas e de aminoácidos sulfurados (metionina, cistina); menor teor de óleo; sabor adocicado semelhante ao das nozes; cor clara e uniforme das sementes (cotilédones, tegumento e hilo), preferencialmente creme; menores teores de ácidos graxos insaturados como o linolênico e linoleico; menores 
teores de lipoxigenase. No ocidente, a soja tem entrado na dieta alimentar de uma forma indireta, como a proteína vegetal texturizada (PVT ou carne de soja), as farinhas integral e desengordurada, a lecitina e tocoferol (vitamina E) que entram na constituição de embutidos, hambúrgueres, leite em pó, pães, massas salgadas, biscoitos, chocolates, sorvetes (Vello, 1992a).

No trabalho de Watanabe et al. (1990), os resultados indicaram que $69,9 \%$ do germoplasma mundial apresenta sementes com PCS $>23$ g. O germoplasma japonês representa $65 \%$ de todo o germoplasma mundial e $82,9 \%$ deste apresenta PCS > $23 \mathrm{~g} / 100$ sementes. No germoplasma chinês $50 \%$ dos genótipos apresentam peso maior que $23 \mathrm{~g} / 100$ sementes. O tegumento amarelo ocorre em aproximadamente $74 \%$ do germoplasma mundial, $49 \%$ no chinês e de $20 \%$ no japonês.

Cozimento lento, sabor amargo ou adstringente ou semelhante ao de feijão cru de paladar ruim são características da soja tipo grão. Ao contrário, a soja tipo hortaliça tem sabor mais suave, com sementes maiores e cozimento mais rápido, podendo ocasionalmente ser mais rápido até que o feijão. A composição química nutricional entre os tipos de soja têm pequena variação, principalmente no teor de proteínas, todavia, alguns cultivares tipo alimento podem apresentar maiores quantidades de proteina (Carrão-Panizzi, 1987).

O edamame nos Estados Unidos apresenta várias denominações, o mais comum é de soja hortaliça; existem também as denominações de soja comestivel, soja verde, entre outras; nesse país, as pesquisas são realizadas há cerca de 50 anos e foram obtidos 49 cultivares de soja tipo hortaliça. Atualmente, apenas poucos pequenos horticultores cultivam a soja tipo hortaliça nos Estados Unidos; assim, a produção é pequena, ficando os consumidores dependentes de importados congelados, que são 
encontrados em supermercados especializados, segundo Konovsky \& Lumpkim ${ }^{1}$ citado por Pacova (1992).

Tem ocorrido um aumento mundial no interesse pela soja de sementes grandes, principalmente do tipo hortaliça, cujas produções têm sido incrementadas em escala comercial na Argentina, Austrália, Israel, Mongólia, Nova Zelândia, Taiwan e Tailândia; e em pequenas quantidades na Alemanha, Butão, Brasil, Grã-Bretanha, Chile, França, Filipinas, Índia, Indonésia, Malásia, Nepal, Singapura e Sri Lanka, porém com aumentos na produções (Konovsky \& Lumpkim citado por Pacova (1992)).

A proteína da soja é a única do reino vegetal, com possibilidade de substituir as proteínas animais sob o ponto de vista nutricional, pois contém todos os aminoácidos essenciais e em proporção adequada, sendo possível a sua produção em grande escala (Canto \& Turatti, 1989). O custo para se produzir a proteína da soja de acordo com Carrão-Panizzi (1988) é aproximadamente 15 vezes menor que o da carne bovina, 16 vezes menor que o dos ovos e 27 vezes menor que o do leite.

A constituição genética é responsável pelo conteúdo de proteína, de aminoácidos, de ácido linolênico, de rafinose e de estaquiose, enquanto que os carboidratos, o pinitol, a sacarose, as cinzas, o fósforo e o cálcio são influenciados principalmente pelo ambiente; tais informações são muito úteis para os programas de melhoramento (Taira, 1990).

\subsection{Problemas relacionados à soja para alimentação}

Um baixo consumo de soja tem sido observado no ocidente, sendo que muitas justificativas são usadas, como por exemplo o sabor não adequado aos padrões aceitos, o odor considerado muito ruim, altamente estável nos produtos; e, seus efeitos ao nivel fisiológico no ser humano.

${ }^{1}$ KONOVSKY, J. \& LUMPKIM, T.A. Edamame production and use: a global perspective. In: NA INTERNATIONAL CONFERENCE SOYBEAN PROCESSING AND UTILIZATION. Gongzhuling, Jilin Province, China, 1990. 12p. 
$\mathrm{Na}$ maturidade da planta é observado um aumento do sabor desagradável do grão da soja, sendo que dois componentes principais são os responsáveis: a) os que produzem o "beany flavor" ou sabor de feijão cru ou herbáceo, formados pelos compostos voláteis, sendo originados pela oxidação do ácido linolênico e outros lipídeos poliinsaturados sob a ação das lipoxigenases; b) os responsáveis pelo sabor amargo e adstringente, ou seja os compostos não-voláteis, formados pela degradação dos hidroperóxidos numa fase inicial, produzindo compostos como o nhexanal, além de vários outros (Rackis et al., 1972 e 1979).

Os principais compostos voláteis detectados na soja são: metanol, etanol, 2-pentanol, isopentanol, pentanol, hexanol e acetato pentanol, além de outras dezenas de substâncias, sendo que os mais importantes para a presença do beany flavor são o isopentanol, hexanol e heptanol (Arai et al., 1967, citado por Maga, 1973).

As lipoxigenases presentes nas sementes de soja são três isozimas denominadas lipoxigenases 1,2 e $3(\mathrm{Lx} 1, \mathrm{Lx} 2$ e $\mathrm{Lx} 3)$ que catalisam as reações de oxidação dos ácidos graxos insaturados (linolênico e linoleico) em compostos do tipo hexanal, responsáveis pelo sabor e odores indesejáveis (beany flavor). Como as lipoxigenases estão separadas dos ácidos graxos nas sementes, armazenadas em lisossomos, as reações só ocorrem quando as sementes sofrem danos mecânicos e em condições de umidade elevada. Vários tratamentos foram propostos para impedir a ação das lipoxigenases, baseados na inativação pela ação do calor ou pela extração com solventes, mas Barros et al. (1984) afirmam que todos esses métodos não atingem níveis satisfatórios, além de serem onerosos. Uma estratégia mais eficaz e de baixo custo, para contornar esse problema seria a incorporação de alelos recessivos em cultivares comerciais e com isso promover a ausência de lipoxigenase.

Existem pesquisas procurando selecionar linhagens com ausência do gene dominante para produção de lipoxigenase e seu emprego como parental visando a introgressão de alelos gênicos recessivos em cultivares comerciais, Davies et al. (1987), Carrão-Panizzi (1989) e Moreira et al. (1991). Paralelamente, tentativas vem sendo 
realizadas para a obtenção de cultivares com baixos teores de oligossacarideos (rafinose e estaquiose (Hymowitz et al., 1972) e de fatores antinutricionais (Orf, 1989).

Em cruzamentos recíprocos realizados, obteve-se que o modo de herança da lipoxigenase 1 é de dominância simples (Hildebrand \& Hymowitz, 1982); os resultados não indicaram presença de efeito materno ou citoplasmático. Estudos adicionais mostraram não haver ligação entre o loco que codifica a lipoxigenase 1 (Lx1) com os locos $w 1$ (flor púrpura), Le (presença de lecitina) e $s p l$ (atividade de $\beta$ amilase), sendo que estes componentes apresentam herança genética recessiva simples. Para os locos $\ln$ (folíolo estreito; quatro sementes/vagem), $p c$ (pubescência crespa), $f$ (haste ramificada), $i$ (controle da cor do hilo), $r$ (controle da cor do tegumento marrom), $d t 1$ (controle do hábito de crescimento determinado), lfl (folhas trifoliadas) e pl (pubescência presente), não foi observada ligação com a lipoxigenase 1 (Pfeiffer \& Hildebrand, 1991).

Foi observada forte ligação entre o loco Lx1 com o Lx2, ambos independentes de Lx3 (lipoxigenase 3). Um grande número de sementes foram abortadas na ausência dos locos Lx1 e Lx2 no estudo realizado por Davies \& Nielsen (1986). Taxas de segregação em $\mathrm{F}_{2}$ e $\mathrm{F}_{3}$ indicaram um controle gênico de dominância simples para o Lx3 e que os alelos para Lxl e Lx3 condicionam fenótipos diferentes, devido atuarem em substratos diferentes (Kitamura et al., 1983).

Confirmando os resultados anteriores, Hajika et al. (1992) relatam que a biossíntese de cada lipoxigenase é controlada por um gene dominante, existindo uma forte ligação entre os locos Lx1 e Lx2, ambos herdados independentemente do loco Lx3. Linhagens deficientes para as três lipoxigenases, obtidas através de radiação gama, não apresentaram nenhuma anormalidade fisiológica, descartando a suspeita de serem importantes para etapas de biossíntese da planta (Hajika et al., 1991). Num estudo comparativo entre dez isolinhas para as lipoxigenases e sua relação com o desenvolvimento da planta, senescência e resistência a pragas, obteve-se indicações de que os embriões com ou sem lipoxigenase apresentaram as mesmas resistências às 
doenças; adicionalmente existe hipótese de que em cada fase da planta há produção de lipoxigenases distintas (Pfeiffer et al., 1992). Isto indica que novas linhagens deficientes nas lipoxigenases poderão ser obtidas nos programas de melhoramento, tornando possível reunir sementes com sabor e odor agradáveis em plantas de desenvolvimento normal.

$\mathrm{Na}$ análise de atividade de $\mathrm{Lx} 1$ e Lx3, o cultivar Doko apresentou valores muito altos e para FT-2 foi de média a baixa, permitindo a formação de grupos estatisticamente diferentes (Barros et al., 1984). Variação possivelmente devida à presença de genes reguladores agindo na atividade das lipoxigenases, segundo Hamond et al. (1992) e Kitamura et al. (1983), ao contrário, não encontraram evidências da presença de genes modificadores ou interações epistáticas com relação às lipoxigenases Lx1 e Lx3 dos grãos de soja.

A produção de hexanal de odor indesejável nos grãos de soja, é catalisada em quantidades diferentes pelas três lipoxigenases; sendo que a Lx3, por sua vez, diminui a formação de hexanal por transformar o substrato em produtos preliminares que interrompem o processo final de formação (Hildebrand et al., 1990).

Em testes para 'flavor' realizados com isolinhas de 'Century', diferindo pela presença ou ausência de $\mathrm{Lx} 1, \mathrm{Lx} 2, \mathrm{Lx} 3, \mathrm{Lx} 1 \mathrm{Lx} 3$ ou $\mathrm{Lx} 2 \mathrm{Lx} 3$, a forma $\mathrm{Lx} 2$ foi a maior responsável pelo sabor indesejável, enquanto Lxl e Lx3 não o alteravam significativamente. Tal fato indica que a remoção do alelo que produz a isozima Lx2 é suficiente para a obtenção de uma soja com sabor mais agradável (Davies et al., 1987).

Uma alozima alterada da lipoxigenase 1 foi observada por Pfeiffer et al. (1993), sendo que linhagens que as possuem não apresentam a lipoxigenase 2. Denominando esta alozima com a simbologia genética $L \times 1^{b}$, e constituição genotípica $\mathrm{Lx} 1^{\mathrm{b}} \mathrm{Lx} 1^{\mathrm{b}} \mathrm{lx} 2 \mathrm{~lx} 2$, os materiais que apresentam esta constituição são importantes por melhorar o sabor da soja e reduzir o tempo para se eliminar esse alelo Lx2 indesejado em outros genótipos. 
Em cruzamentos realizados em soja foi observada uma segregação na geração $F_{2: 3}$ de 1:14:1, no conteúdo de ácido linolênico em óleo de soja que é associado com odor e outras características, levantando-se a hipótese de existir ação de genes principais em dois locos independentes (Fehr et al., 1992). A distribuição contínua indicou que os genes principais e o efeito ambiental são importantes na expressão do conteúdo de ácido linolênico, devendo ser tratado como um caráter quantitativo.

\subsection{Substâncias antinutricionais}

Existe um outro grupo de compostos químicos associados a problemas fisiológicos no organismo humano, são os fatores anti-nutricionais, sendo que o principal é a anti-tripsina Kunitz, que inibe as proteases existentes no organismo; sua presença encarece a soja para uso alimentar, pois se torna necessário o aquecimento para inativá-la

$\mathrm{O}$ alto teor de proteína e minerais e a baixa atividade do inibidor de tripsina (TI) são qualidades desejáveis para a soja tipo hortaliça, que apresenta melhor sabor, aroma, textura, cozimento e baixa atividade de TI do que o tipo grão (Mohamed et al., 1991). Poucos trabalhos foram realizados sobre a variação genética de TI entre genótipos (Mohamed \& Rangappa, 1992).

Na avaliação de genótipos mutantes de 'Century', Hildebrand \& Pfeiffer (1991) sugerem o seguinte processo de formação dos ácidos graxos:

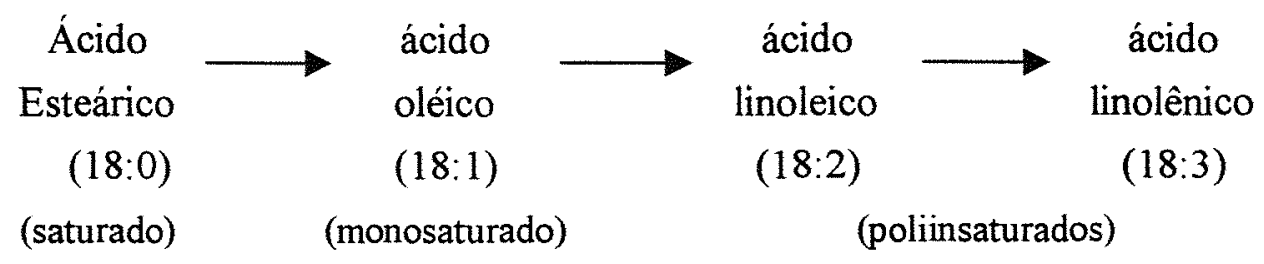

Caso o controle gênico proposto em cada etapa seja confirmado, a obtenção de cultivares com menor atividade de lipoxigenase 1 , possibilitará a produção de menores teores de substâncias indesejáveis, por impedir a formação das demais na 
cadeia. Hildebrand \& Pfeiffer (1991) observaram também um efeito materno para baixo conteúdo de ácido oléico e uma herança complexa para teor de ácido linolênico.

Os fitatos são também considerados como um fator antinutricional, devido aos seus efeitos negativos na disponibilidade de micronutrientes; em estudos de Mohamed \& Pearson (1997), foram observados efeitos de locais e da interação G x E, sobre a quantidade de fitatos em soja.

Finalmente, é necessário considerar que um cultivar melhorado para caracteres de soja tipo hortaliça também deve apresentar outras características para que seja aprovada a sua recomendação junto aos agricultores, produtores de sementes e consumidores rotineiros, ou seja, precisa ser competitivo comercialmente, em produtividade, além de apresentar as demais características desejáveis (tamanho de semente, cor, teor de proteína, sabor, etc.).

\subsection{Composição química de sementes de soja}

Os grãos de soja tipo alimento no estádio $R_{6}$, apresentaram uma média de $39 \%$ de proteína, $20 \%$ de óleo, $2 \%$ de açúcares redutores e não-redutores de um total de $21 \%$ de carboidratos, $5 \%$ de teor de cinzas e $4 \mathrm{mg} / 100 \mathrm{~g}$ de ácido ascórbico. Para a fração óleo sozinha, as seguintes porcentagens foram encontradas, em genótipos tipo alimento e tipo grão respectivamente: 11 e $10 \%$ de ácido palmítico, 3 e $2 \%$ de ácido esteárico, 41 e $46 \%$ de ácido oléico, 41 e $39 \%$ de ácido linoleico, 4 e 3\% de ácido linolênico (Deodhar et al., 1973).

\subsection{Herança de caracteres}

\subsubsection{Período juvenil e tolerância ao fotoperíodo}

O ciclo da soja pode ser dividido em dois períodos principais: vegetativo e reprodutivo. Por sua vez o período vegetativo é subdividido nos períodos juvenil e indutivo. $\mathrm{O}$ periodo juvenil compreende o número de dias entre a data de 
emergência da plântula até a data em que, mesmo recebendo condições fotoperiódicas adequadas para iniciar o processo de indução floral, a planta mantém-se neutra ou nãoresponsivel ao fotoperíodo. O período juvenil tem uma duração mínima de nove dias (Shanmugasundaram \& Tsou, 1978). Quanto maior o período juvenil maior será a tolerância da planta ao fotoperiodo. Já se dispõe de genótipos com mais de 30 dias de período juvenil: PI 159925, PI 240664 (Hinson, 1989; Kiihl \& Garcia, 1989, Sinclair \& Hinson, 1992) e PI 297550 (Buzzell \& Voldeng, 1981). O controle genético do período juvenil longo é feito por genes recessivos, havendo controvérsias se é por apenas um único gene (Toledo \& Kiihl, 1982b) ou mais que um gene de acordo com a comunicação pessoal de R.A.S., Kiihl mencionada por Destro (1991). Kiihl (1976) questionou se a associação entre período juvenil longo e tolerância ao fotoperíodo pode expressar-se tanto em semeaduras antecipadas quanto em semeaduras atrasadas. A soja tipo alimento com sementes grandes, têm sensibilidade fotoperiódica muito elevada, afetando negativamente a produtividade e outras características agronômicas importantes.

Estudos realizados para caracterizar de um modo mais completo as consequências fisiológicas do período juvenil longo; envolvendo enxertias recíprocas indicaram que o número relativo de enfolhamento estava associado com o atraso no florescimento; aparentemente, a expressão deveu-se a um material translocado, que diminui a quantidade ou a atividade de fotoreceptores presentes nas plantas (Sinclair \& Hinson, 1992).

\subsubsection{Maturidade}

A herança da maturidade ou ciclo em soja é considerada como sendo um caráter quantitativo. Contudo, existem resultados que indicam a presença de um controle também por genes principais.

Cinco pares de alelos (cinco locos) independentes, descritos como E1/e1, E2/e2, E3/e3, E4/e4 e E5/e5, são conhecidos no controle da maturidade em resposta às condições ambientais (McBlain \& Bernard, 1987; Buzzell, 1971). A presença 
de dois pares de alelos independentes afetando a maturidade, atuando como genes principais, sendo que os alelos dominantes determinam o florescimento e a maturidade tardios, foi observada por Bernard (1971). O alelo recessivo e3 confere uma insensibilidade à luz fluorescente e, desse modo, altera o tempo para que a planta atinja a maturidade nestas condições (Buzzell, 1971).

Quando as condições de fotoperíodo são alteradas de dias curtos para dias longos, fenômeno que ocorre em locais de altas latitudes, o tempo para florescimento e para maturidade se alteram, pois a planta retarda seu florescimento e consequentemente ocorre um atraso na maturidade (Hartwig \& Kïhl, 1979). Os alelos dominantes determinaram florescimento e maturidade precoces em quatro mutantes e seus respectivos cultivares originais na latitude de $20^{\circ} 45^{\prime}$ LS sob dois fotoperiodos diferentes (Gilioli et al., 1984); comportamento semelhante foi observado por Bonato (1989). Estes estudos confirmam as conclusões de Toledo \& Kiihl (1982a) da existência de um gene cujo alelo recessivo causava um aumento no ciclo da planta.

Não tem sido observada ligação entre genes condicionando caracteres quantitativos, no caso tempo para florescimento e para maturidade, mas entre genes controlando altura da planta e produtividade ocorreu ligação significativa (Gates et al., 1960).

\subsubsection{Produtividade, altura da planta e valor agronômico}

A produtividade de grãos e a altura da planta são caracteres considerados de herança quantitativa. $\mathrm{O}$ valor agronômico tem sido pouco estudado, pois é um caráter de avaliação subjetiva (notas visuais), combinando vários outros caracteres importantes, como produtividade, altura da planta, acamamento, sanidade.

$O$ controle gênico do período reprodutivo e da altura da planta no florescimento diferem do apresentado para altura da planta na maturidade, existindo um grande efeito ambiental; em ambientes sombreados há uma tendência das plantas crescerem mais em altura com um número menor de ramificações; já em ambientes 
ensolarados, há menor crescimento em altura e maior número de ramificações (Camacho, 1971).

Estimativas de herdabilidade dos caracteres variando de 75 a $95 \%$ para número de dias para maturidade, de 46 a $81 \%$ para período reprodutivo, de 66 a $90 \%$ para altura da planta, 3 a $58 \%$ para produtividade de grãos, foram obtidos por Brim (1973) e Burton (1987). Destro (1991) obteve 34\% e 66\% para período reprodutivo em topocruzamentos que envolveram o parental Doko e FT-2, respectivamente.

Os valores de herdabilidade no sentido amplo variaram entre os caracteres: número de dias para maturidade, $42 \%$ a $99 \%$ (Chauhan \& Singh, 1984; Freire Filho, 1988; Lin \& Nelson, 1988; Bonato, 1989; Destro, 1991); altura da planta na maturidade, 31\% a 92\% (Chauhan \& Singh, 1984; Freire Filho, 1988; Lin \& Nelson, 1988; Destro, 1991); produtividade de grãos, 50\% a 95\% (Chauhan \& Singh, 1984; Freire Filho, 1988), Destro (1991) encontrou valores próximos de 40\%, enquanto que Pacova (1992) obteve um valor médio de 37\%; para o valor agronômico, $80 \%$ (Freire Filho, 1988), 34\% para topocruzamentos envolvendo o parental Doko e $60 \%$ para os envolvendo o parental FT-2 (Destro, 1991) e 63\% (Pacova, 1992). Na estimativa do coeficiente de determinação genotípica, realizada por Yokomizo (1994) foi obtido $91 \%$ para número de dias para maturidade, $94 \%$ para altura da planta na maturidade e $73 \%$ para produtividade de grãos.

Também foi observada grande variação nos valores de herdabilidade no sentido restrito entre os caracteres: altura da planta na maturidade, de $0 \%$ a $94 \%$ (Caviness \& Prongsirivathana, 1968; Singh et al., 1974; Weaver \& Wilcox, 1982; Cecon et al., 1984a, 1984b; Pereira et al., 1984; Freire Filho, 1988; Bonato, 1989; produtividade de grãos, de 13\% a 58\% (Anand \& Torrie, 1963; Singh et al., 1974; Weaver \& Wilcox, 1982; Pereira et al., 1984; Freire Filho, 1988); valor agronômico, 29\% (Freire Filho, 1988), 17\% (em média; Pacova, 1992). Já Yokomizo (1994) encontrou o valor de $92 \%$ na estimativa do coeficiente de determinação genotípica para valor agronômico. 
A variância de dominância também apresenta importância para alguns caracteres: produtividade de grãos e altura da planta (Leffel \& Weiss, 1958), período reprodutivo e produtividade de grãos (Brim \& Cockerham, 1961); altura da planta (Croissant \& Torrie, 1971). Em alguns casos, pode ocorrer da variância dominante ser superior à variância aditiva, como foi observado por Chaudary \& Singh (1974) para produtividade de grãos; por Leffel \& Hanson (1961) para produtividade, maturidade e altura da planta; por Camacho (1971) para período reprodutivo e altura da planta no florescimento.

Efeitos de epistasia do tipo aditiva $\mathrm{x}$ aditiva tem contribuição significativa na altura da planta, maturidade e produtividade (Brim \& Cockerham, 1961); para a maturidade e produtividade de grãos este tipo de epistasia foi responsável por mais de $50 \%$ da variabilidade genética total e para a altura da planta foi de $20 \%$ (Hanson et al., 1967).

A epistasia aditiva $x$ aditiva representa uma porção maior da variabilidade genotípica do que a variância aditiva em soja; devido a isso, a seleção em gerações iniciais de endogamia tende a ser menos efetiva, ou seja, o teste de geração precoce pode ser o método menos adequado a ser utilizado para a seleção das progênies, em função da menor probabilidade de se obterem combinações gênicas favoráveis, conforme o número de genes envolvidos. $O$ progresso na seleção é mais lento na presença de epistasia aditiva $\mathrm{x}$ aditiva do que na predominância de variância aditiva nos caracteres avaliados, (Brim, 1973).

\subsubsection{Tamanho das sementes e largura das vagens}

Uma grande variação do tamanho das sementes de soja é relatada, podendo-se observar desde 4 até 55g / 100 sementes, conforme Hartwig (1973). A maior parte $(63 \%)$ do germoplasma mundial apresenta PCS entre 19 e $31 \mathrm{~g}$ (Watanabe \& Nagasawa, 1990). 
Para o consumo humano direto, cultivares com tamanho grande de semente ( $>20 \mathrm{~g} / 100$ sementes) são os preferidos, sendo que cruzamentos entre parentais de sementes grandes têm sido empregados para obtenção de cultivares tipo alimento; neste caso, pode-se ter o problema de menor produtividade destes em relação aos cultivares com sementes médias (PCS $=12$ a 19g); Bravo et al. (1981). Um estudo de segregação para tamanho das sementes ern cruzamentos, indicou que a média da população observada foi predita pela média aritmética ou geométrica dos parentais, refletindo a participação de ação gênica aditiva e ou epistasia aditiva $\mathrm{x}$ aditiva no controle do tamanho das sementes. Os dados demonstraram claramente a dificuldade de se obter uma frequência adequada de progênies com tamanho de sementes igual a do parental de sementes grandes, em cruzamentos que envolveram cultivares de sementes pequenas. Portanto, deve-se ter um cuidado especial na escolha dos parentais e no desenvolvimento da população segregante. Para aumentar o tamanho das sementes pode-se sugerir o retrocruzamento do $F_{1}$ (de um cruzamento biparental) com o parental de sementes grandes ou cruzar o $F_{1}$ com um outro parental também com sementes grandes.

O efeito das diferentes proporções de plantas introduzidas (PI) sobre a produtividade, altura da planta na maturidade e acamamento de cultivares adaptados, baseado em cinco diferentes porcentagens de PI em populações com base genética ampla, foi estudado por Vello et al. (1984); verificou-se que a população obtida com $25 \%$ de PI, ou seja, cruzamento $F_{1}$ (parental adaptado $\mathrm{x} P \mathrm{PI}$ ) retrocruzado para os parentais adaptados, apresenta a quantidade de genes exóticos introduzidos que maximiza a variabilidade genética sem causar reduções drásticas na produtividade média de grãos. Talvez, a contribuição de $25 \%$ de um parental com sementes pequenas ou uma PI seja adequada para elevar a produtividade de grãos de genótipos de sementes grandes. Além disso, devido ao efeito maternal sobre o tamanho das sementes é recomendável utilizar o parental de sementes grandes como fềmea, tanto no cruzamento inicial quanto em possíveis retrocruzamentos (Miranda et al., 1984). Um fato que pode dificultar é a presença de efeitos citoplasmáticos observada por Daydé et al. (1989) reduzindo a produtividade de sementes nesses parentais de sementes grandes. 
Em estudo para verificar a ligação entre genes controladores de caracteres quantitativos, não foi observada ligação entre tamanho das sementes com outros caracteres avaliados, mas houve predominância da variância aditiva para o caráter (Gates et al., 1960; Brim \& Cockerham; 1961; Destro, 1991). Quanto a herança do tamanho das sementes, além da variância aditiva tem sido observados outros componentes: epistasia aditiva x aditiva (Hanson \& Weber, 1961); de dominância (Croissant \& Torrie, 1971). Para produtividade de grãos foi observada variância aditiva e de dominância enquanto que para tamanho de sementes observou-se predominância de variância aditiva (Singh et al., 1974).

Estimativas de herdabilidade para o caráter tamanho das sementes em soja variando de $44 \%$ a $94 \%$, foram observadas em revisões realizadas por Brim (1973) e Burton (1987). Médias de 36\% a 77\% para a herdabilidade no sentido restrito foram obtidas por Anand \& Torrie (1963), de $95 \%$ por Pereira et al. (1984), de 15\% por Destro et al. (1987), de 19\% por Pacova (1992). Valores de $42 \%$ a $87 \%$ para herdabilidade no sentido amplo foram obtidos por Harrinson et al. (1981), Chauhan \& Singh (1984), Pereira et al. (1984) e Destro (1987).

Estudos entre gerações $F_{4}$ e $F_{5}$ de soja, permitiu a estimativa de herdabilidades no sentido amplo com base em componentes de variância ao nível de planta individual, de parcela e de média de familia, apresentando valores variando de $70 \%$ a $96 \%$ para comprimento, largura e área das vagens. Para o tamanho das sementes os valores variaram de $63 \%$ a $93 \%$ (Frank \& Fehr, 1981).

Foram observadas herdabilidades no sentido amplo para tamanho de sementes de $35 \%$ ao nível de planta, $52 \%$ ao nível de parcela e $89 \%$ ao nível de média de família; para largura das vagens, os resultados foram $35 \%$ ao nível de planta, $51 \%$ ao de parcela e $87 \%$ com média de família, (Leroy et al., 1991). Já Destro (1991) observou herdabilidades médias no sentido amplo na geração $F_{2}$, para tamanho de sementes de $34 \%$ para os topocruzamentos com 'Doko' e 36\% com 'FT-2' em estudo de 41 genótipos de soja tipo hortaliça topocruzados com aqueles dois cultivares; na geração $F_{3}$, foram 
obtidos valores de $62 \%$ para os topocruzamentos com 'Doko' e $31 \%$ para os com 'FT-2' (Pacova, 1992).

O coeficiente de determinação genotípica é calculado de modo semelhante à herdabilidade e é utilizado quando se trabalha com efeitos fixos de genótipos ou cultivares. Em 39 genótipos de soja próprias para o consumo humano, na maioria exóticos, foram estimados valores de coeficiente de determinação genotípica para a largura das vagens próximos de $90 \%$ na fase imatura e $80 \%$ na madura; para o tamanho das sementes maduras, os valores variaram entre $70 \%$ a $90 \%$, (Santos, 1988). Para a largura visual das vagens, foi obtido o valor de $91 \%$ e para o tamanho da sementes de 96\% (Yokomizo, 1994).

\subsubsection{Comparação das estimativas de variabilidade}

As diferenças genéticas entre as populações de plantas, a precisão e os padrões adotados para avaliação, as épocas, as condições experimentais, os métodos de estimação, podem levar a diferenças nos valores estimados dos parâmetros relacionados à variabilidade (p.ex. herdabilidade). Portanto, comparações de trabalhos devem ser realizadas de maneira muito cuidadosa; uma sugestão para se evitar esses problemas, seria a utilização de métodos de ponderação. Apesar desses problemas, tem se observado uma herdabilidade para o tamanho das sementes de soja de no mínimo $40 \%$. Alguns resultados têm mostrado que a herdabilidade para a largura das vagens é maior que a do tamanho das sementes, possibilitando a seleção via indireta para o tamanho das sementes em soja, uma vez que existe uma forte associação positiva entre esses dois caracteres (Bravo, 1980; Pacova, 1992, Yokomizo, 1994).

\subsection{Correlação entre caracteres}

Nos programas de melhoramento geralmente não se visa aprimorar um único caráter e, sim, um conjunto destes simultaneamente; deste modo, é muito importante o estudo da natureza e da magnitude das relações existentes entre os 
caracteres. $\mathrm{O}$ conhecimento de como uma característica pode causar alterações em outras torna-se muito importante (Vencovsky, 1992b).

Um fato importante a se destacar é que as correlações entre caracteres obtidas com base em parcelas (Johnson et al., 1955) e em médias de progênies (Bravo et al., 1980) geralmente são mais precisas em relação às obtidas com base em plantas individuais.

\subsubsection{Tamanho das sementes com tamanho das vagens}

Correlações fenotípicas entre largura visual das vagens e produtividade de grãos foram significativas, sendo de $55 \%$ com base em plantas individuais e $64 \% \mathrm{com}$ base em médias de famílias, em estudo conduzido por Bravo et al. (1980). Estes autores observaram também que o uso da largura das vagens para seleção indireta para aumentar o peso de sementes de soja foi mais eficiente do que o uso do peso de semente per se. É importante considerar que a correlação é maximizada quando o desenvolvimento das sementes ocorre sem restrição de nutrientes. Além disso 20 dias após a polinização as vagens atingem a sua largura máxima. As vagens de alguns genótipos cultivados em ambientes específicos atingem o máximo do desenvolvimento antes de cessar o florescimento, permitindo a seleção de materiais que poderão ser empregados em cruzamentos. Valores de correlações iguais a $-5 \%$ e $-34 \%$ para cruzamentos com Doko e $-7 \%$ e $-57 \%$ para os com FT-2 em análise de plantas individuais e para médias, respectivamente, foram obtidos por Yokomizo (1994), contrastando em relação aos obtidos por Bravo et al. (1980).

O número de sementes presentes nas vagens não tem importância prática na largura ou espessura das vagens (Frank \& Fehr, 1981); além disso, a seleção para comprimento ou largura das vagens em vagens cheias imaturas foi tão efetiva quanto nas maduras. A largura de vagem entre as outras dimensões avaliadas, foi considerada como o caráter mais eficiente para uso na seleção indireta, além de ser a mais fácil de se obter. As correlações fenotípicas entre a largura e o tamanho das sementes foram 
altamente significativas, com valores de $66 \%$ para vagens imaturas e $76 \%$ nas maduras. A correlação da largura das vagens com o tamanho final das sementes, apresentou valor igual a 96\% para Fraser et al. (1982); já para Shanmugasundaram \& Chung-Ruey (1982) os valores foram próximos de $60 \%$, os valores mais altos de correlação entre peso de cem sementes e largura das vagens foram obtidas por Santos (1988): $80 \%$ a $90 \%$ na fase imatura; $60 \%$ a $80 \%$ na fase madura.

As estimativas de correlações genotípicas maiores que $97 \%$ entre a largura das vagens medida por paquímetro e a largura visual das vagens (LVV), abriu a possibilidade de LVV substituir as medições com paquímetro, facilitando e agilizando a avaliação. A correlação obtida por Pacova (1992) entre LVV e peso de cem sementes foi no mínimo 81\%; Yokomizo (1994) obteve valores altos próximos a $90 \%$ de correlações fenotípicas entre largura visual das vagens e tamanho das sementes.

Pelo que se pode observar, existe uma correlação alta e positiva entre a largura das vagens e o tamanho das sementes, permitindo que se substitua o peso de cem sementes pela nota de vagem. Para a seleção é importante não permitir um déficit de nutrientes e nem de água na fase de granação, para evitar a obtenção de vagens chochas, fato que poderia invalidar os valores das correlações e, com isso, dificultar o processo de seleção.

\subsubsection{Tamanho das sementes e outros caracteres}

As correlações genotípicas entre o tamanho das sementes e a produtividade de grãos apresentam uma grande variação, sem uma definição exata de sua tendência, pois os valores obtidos variam de $-60 \%$ a $66 \%$ (Johnson et al., 1955; Anand \& Torrie, 1963; Kwon \& Torrie, 1964; Burris et al., 1973; Harrison et al., 1981; Santos, 1988). Em programa de pesquisa conduzido na ESALQ, Yokomizo (1994) obteve estimativas ao nível de parcelas de correlações fenotípicas iguais a $-49 \%$ e $-64 \%$ em cruzamentos com Doko e FT-2, respectivamente, estes valores de correlação também se alteram com o tipo (grão, broto/nattô e hortaliça) de soja avaliado (Pacova, 1992). No 
mesmo programa, Yokomizo (1994) observou tendências de estimativas negativas e altas para as correlações entre PCS e os seguintes caracteres, considerando respectivamente os topocruzamentos com 'Doko' e 'FT-2': $-55 \%$ e $-34 \%$ com acamamento; $-67 \%$ e $-68 \%$, com altura da planta na maturidade; $-52 \%$ e $-39 \%$, com número de dias para a maturidade.

No trabalho de Leroy et al. (1991), envolvendo cruzamentos de soja tipo broto ou nattô (PCS $<10 \mathrm{~g}$ ), as seguintes estimativas de correlações fenotípicas foram obtidas entre tamanho de sementes e os seguintes caracteres: número de dias para a maturidade, $-49,3 \%$; altura da planta na maturidade, $-34,75$; acamamento, $-57,3 \%$.

Os seguintes intervalos de variação foram observados para as correlações entre o tamanho das sementes com outros caracteres: número de dias para florescimento, 0,07 a $-0,4$; altura da planta na maturidade, 11 a $-0,47$; período reprodutivo, $-0,05$ a 0,29 ; acamamento, 0,03 a $-0,02$, conforme por Kwon \& Torrie (1964), Johnson et al. (1955), Pacova (1992).

\subsubsection{Outros caracteres}

As estimativas obtidas para as correlações genotípicas entre produtividade de grãos com número de dias para florescimento não apresentaram um padrão definido, havendo trabalhos com valores não-significativos até os significativos e positivos, variando de $-2 \%$ a $87 \%$ (Weber \& Moorty, 1952; Johnson et al., 1955; Kwon \& Torrie, 1964; Freire Filho, 1988). O mesmo comportamento tem sido observado para a correlação da produtividade de grãos com o periodo reprodutivo, variando $-3 \%$ a $71 \%$ (Weber \& Moorty, 1952; Johnson et al., 1955; Kwon \& Torrie, 1964).

Para a correlação da produtividade de grãos com o número de dias para maturidade com altura da planta, tem ocorrido a predominância de correlações positivas e altas (Weber \& Moorty, 1952; Johnson et al., 1955; Anand \& Torrie, 1963; Kwon \& Torrie, 1964; Byth et al., 1969; Harrison et al., 1981; Freire Filho, 1988). 
Entre o número de dias para a maturidade e altura da planta na maturidade, as correlações variaram de $30 \%$ a $90 \%$ (Weber \& Moorty, 1952; Johnson et al., 1955; Anand \& Torrie, 1963; Kwon \& Torrie, 1964; Byth et al., 1969; Freire Filho, 1988; Lin \& Nelson, 1988; Pacova, 1992). Entre produtividade de grãos e largura das vagens, Santos (1988) encontrou correlações não-significativas.

As correlações fenotípicas entre produtividade de grãos e valor agronômico da planta, apresentaram valores de $13 \%$ para os parentais e $52 \%$ na geração $\mathrm{F}_{2}$ (baseadas em plantas individuais) e de $-49 \%$ e $-0,02 \%$ (baseadas em médias de parcelas) no trabalho de Freire Filho (1988). Yokomizo (1994) obteve 75\% para topocruzamentos com Doko e $91 \%$ para os com FT-2.

A correlação entre o inibidor de tripsina (indesejável na soja alimento) com proteína total apresentou valor de $-53 \%$, altamente significativo, indicando facilidade para se selecionar materiais ricos em proteína com menor teor de inibidor de tripsina, (Mohamed et al., 1991). A estimativa da correlação entre presença de lipoxigenase com o conteúdo de ácido linoleico, de ácido oléico e de óleo total, apresentaram valores de $57 \%, 30 \%$ e $42 \%$, respectivamente (Hafez, 1983 ).

\subsection{Interação Genótipos x Ambientes}

Sabe-se que a manifestação fenotípica nos vegetais é o resultado da ação conjunta do genótipo com os efeitos ambientais, porém quando se considera uma série de ambientes, surge um efeito adicional de suma importância, proporcionado pela interação do genótipo com os fatores do meio ambiente em que se desenvolve o vegetal.

A avaliação da interação genótipos $\mathrm{x}$ ambientes $(\mathrm{G} \times \mathrm{E})$ torna-se de grande importância no melhoramento, pois no caso de sua existência, há possibilidades do melhor genótipo em um ambiente não apresentar o mesmo desempenho em outro, influenciando o ganho de seleção e dificultando a recomendação de cultivares com ampla adaptabilidade. Apesar de nos últimos 40 anos ter se produzido cultivares com maior produtividade, adaptados as práticas culturais modernas, com incorporação de resistência 
às pragas e doenças, aumento da qualidade das sementes, esses sucessos do passado não fornecem necessariamente provas conclusivas da eficiência dos procedimentos tradicionais empregados no melhoramento (Brim, 1973). Pesquisas devem continuar de modo a visualizar um caminho para aumentar a eficiência do método e a taxa do ganho genético, incluindo:

1. O desenvolvimento de populações melhoradas, levando em consideração a origem genética dos parentais, seu fenótipo geral e seu desempenho em diversos ambientes.

2. O desenvolvimento de um esquema de seleção para caracteres simples e múltiplos que incorpore um ciclo mais rápido de identificação de linhagens elite, seleção e recombinação.

3. A investigação da importância relativa da dominância e da epistasia, particularmente como elas afetam a heterose.

4. O desenvolvimento de caminhos para manipular as interações $\mathrm{G} \times \mathrm{E}$, aumentando desse modo a herdabilidade.

5. A alocação adequada de recursos com respeito a testes preliminares em relação aos avançados.

Para se satisfazer os itens acima mencionados é necessário um conhecimento de como os genótipos interagem com os ambientes.

Em soja, a interação $\mathrm{G} \times \mathrm{E}$ tem sido investigada sob vários aspectos, sendo que nessa revisão serão apresentados os estudos mais recentes, além de se citar os trabalhos mais clássicos considerados importantes para essa cultura.

\subsubsection{Categorias de efeitos ambientais}

Os diferentes efeitos ambientais contribuem para o comportamento observado nos genótipos e estes podem ser divididos em duas categorias, a que envolve fatores previsiveis e a dos fatores imprevisíveis (Allard \& Bradshaw, 1964),

Variação previsivel é devido àquelas condições em que o homem possui controle, ou seja, ambientes de casa-de-vegetação, câmaras de crescimento, efeito de 
irrigação, adubação, métodos de colheita ou outro em que se possa exercer controle. Os fatores que apresentam características permanentes durante o passar dos anos também são considerados previsiveis, por exemplo: o fotoperíodo, o tipo de solo, o relevo, presença de patógenos endêmicos em determinadas épocas do ano.

As variações imprevisiveis compreendem as condições relacionadas geralmente a fatores climáticos, como a pluviosidade atípica em alguns anos, oscilações de temperatura e qualquer outra que não se possa prever com segurança.

Se um ambiente em particular pode ser definido, então torna-se possível desenvolver cultivares adaptados especificamente para o local. Atualmente, cultivares resistentes são desenvolvidos para uso em áreas com doenças e pragas particulares; contudo, algumas vezes, estas podem ser classificadas como imprevisíveis. Para contornar essa dificuldade, a ênfase é dada para o desenvolvimento de cultivares que sejam estáveis, isto é, apresentam bom desempenho numa ampla faixa de ambientes. Muitos programas de melhoramento de soja realizam vários testes regionais para a avaliação de genótipos sobre as mais variadas condições e, para isso, diversas análises têm sido desenvolvidas para determinar a estabilidade relativa dos materiais em teste. Neste sentido, resistência a doenças e pragas podem ser entendidas como uma contribuição importante para a estabilidade de um cultivar e, portanto, causar menor interação $\mathrm{G} \times \mathrm{E}$.

\subsubsection{Exemplos de caracteres que apresentam interação $G \times E$}

Existem caracteres em soja que interagem mais fortemente com as variações do ambiente. Serão relatados a seguir alguns trabalhos com exemplos de interação $\mathrm{G} \times \mathrm{E}$.

Análises de regressão individual para vários caracteres em soja apresentaram interação com o ambiente para a produtividade de sementes por planta, vagens formadas por planta, sementes por vagem, peso de cem sementes, número de dias 
para atingir a maturidade e número de dias para o início do florescimento (Gupta et al., 1982a).

Para os componentes estruturais como altura da planta na maturidade, número de nós por planta, comprimento do internódio, comprimento do pecíolo e número de nós na haste principal, foram poucos os genótipos testados em que a interação $\mathrm{G} \times \mathrm{E}$ não foi significativa.

Realizando uma análise de regressão conjunta, para a produtividade de sementes e seus componentes, Gupta et al. (1982b) observaram a ocorrência de interação significativa também por este método para todos os caracteres estudados, excetuando-se apenas o comprimento das vagens e o número de sementes por vagem. $\mathrm{Na}$ divisão da interação $\mathrm{G}$ x E em componentes lineares e não-lineares os resultados indicaram somente a presença dos lineares ou seja os efeitos previsiveis do ambiente. Por esta técnica, apenas o comprimento do internódio não exibiu interação $G \times E$. Nos caracteres fenológicos, a análise conjunta indicou a presença de interação com importância semelhante entre os componentes lineares (previsiveis) e os não-lineares (imprevisiveis). Para os caracteres fisiológicos como número de folhas por nó e área foliar, a técnica não permitiu determinar o tipo da interação presente.

\subsubsection{Conhecimento fisiológico para a interação $G \times E$}

O conhecimento fisiológico no melhoramento de culturas tem sido utilizado para ajudar a interpretação da interação $\mathrm{G} \times \mathrm{E}$ em termos biológicos e, desse modo, identificar a chave fisiológica e os empecilhos que dificultam o melhoramento de culturas para a produtividade, estabelecendo estratégias para pesquisas agronômicas. Um objetivo frequente é a formulação de ideótipos "dinâmicos" de modo a adequar o ciclo da cultura aos recursos disponiveis, por exemplo, evitando-se a coincidência de fases críticas da planta com condições ambientais desfavoráveis; esse procedimento é possível quando as estações do ano são bem definidas. Uma outra estratégia seria a exploração de 
caracteres fisiológicos conferindo resistência a estresses específicos, mas estudos nessa área são muito escassos.

Estudos da fisiologia (produção de biomassa, fotossintese, respiração, assimilação de nutrientes, respostas a estresses) podem auxiliar o melhorista. $O$ mais significativo desenvolvimento tem sido a transição de análises físiológicas qualitativas para quantitativas e a integração do entendimento fisiológico da cultura com o desenvolvimento de modelos para a predição quantitativa do desempenho das linhagens em condições ambientais particulares. Deve-se lembrar que existem poucas situações onde os efeitos ambientais sejam devidos a um simples fator limitante, podendo se ter, nesse caso, uma interação $G \times E$ sistemática e ser representado por aproximações de regressão, auxiliando o processo de seleção (Lawn \& Imrie, 1991).

\subsubsection{Análises estatísticas para avaliação da interação $G \times E$}

Avaliações estatísticas adequadas são necessárias para que a interação G $\times$ E seja detectada com maior precisão; para tanto, trabalhos têm sido realizados para definir qual a melhor metodologia.

De acordo com Duarte (1988) os métodos baseados num único parâmetro (p.ex. o método de Wricke, 1965) mostram-se pouco informativos, oferecendo menor segurança à recomendação de cultivares em relação àqueles baseados na regressão (Finlay \& Wilkinson, 1963; Eberhart \& Russel, 1966; Silva \& Barreto, 1985). Já Carvalho et al. (1983) obteve resultados indicativos de que o teste de Wricke (1965) apresentou resultados muito próximos aos de Eberhart \& Russel (1966).

A existência de interações significativas entre genótipos e ambientes podem dificultar a análise genética, por confundir estimativas de parâmetros genéticos e estatísticos e, com isso, complicar as estratégias de seleção e testes. Para se tomar decisão em um programa de seleção é necessário um completo entendimento da interação $\mathrm{G} \times \mathrm{E}$, além do fato de que comumente os melhoristas estão interessados em associar mais de um caráter numa progênie. Nesse sentido, Kroonenberg \& Basford (1989) 
propuseram uma técnica para explorar a interação entre vários caracteres de genótipos de soja com os ambientes, fornecendo uma descrição geral de padrões básicos presentes nos dados em termos de interações de três fatores (caracteres, genótipos e ambientes) envolvidos.

Análises de variância padrão conseguem detectar muitas diferenças significativas e a existência de interação, mas não fornecem informações específicas sobre os padrões de resposta; desse modo, a proposta da maioria dos autores é uma técnica complementar descrevendo a contribuição dos diversos caracteres na diferenciação dos genótipos (ou grupos de genótipos) e permitindo ao melhorista integrar um padrão de resposta básico num conjunto de dados de uma maneira direta e racional.

Sem dúvida o efeito do ambiente em muitos casos não pode ser separado dos demais, atrapalhando a precisão das análises estatísticas. Existem três alternativas para contornar esse problema:

1. Melhorar as técnicas experimentais com parcelas maiores, maior uniformidade do solo, melhor uniformidade de manejo com regulagem adequada dos diversos equipamentos utilizados.

2. Maior número de repetições ou distribuição das repetições, como a distribuição em blocos, o uso de blocos aumentados, entre outras alternativas.

3. Melhorar a análise estatística, pois análises estatísticas efetivas podem filtrar a dispersão do padrão dos dados coletados, resultando em maior precisão.

As duas primeiras opções envolvem maior área e custo econômico, enquanto a terceira envolve apenas melhores estimativas por modelos matemáticos, apesar de que com o aumento das duas primeiras, a precisão da terceira será melhor.

Gauch \& Zobel (1988) recomendam combinar uma análise do efeito aditivo principal com um modelo de interações múltiplas (análise denominada $\mathrm{AMMI}$ ). $\mathrm{O}$ AMMI começa com a análise de variância usual (ANOVA) de modo a computar efeitos genotípicos aditivos e ambientais; depois aplica-se a análise de componentes principais 
(PCA) para analisar os efeitos de interações não-aditivas; sem dúvida, a melhor precisão e tributação mais apropriada da interação $\mathrm{G} \times \mathrm{E}$ existente fornecido pelo AMMI afeta o processo de seleção em relação a outras técnicas, além de fornecer um excelente controle do erro quando a interação está presente.

Lembrando que julgamentos baseados em vários anos podem ser mais verdadeiros do que os realizados em apenas um ano, os melhoristas estão acostumados a usar médias ajustadas de vários delineamentos experimentais. $\mathrm{O}$ modelo $\mathrm{AMMI}$ pode ser usado para esses ajustes, aumentando a probabilidade de sucesso na seleção, a velocidade e a efetividade dos programas de melhoramento, além de fornecer maior segurança para a recomendação de cultivares (Gauch \& Zobel, 1989).

Um método que pode ser usado em experimentos desbalanceados para as testemunhas, tão bem como em balanceados (as mesmas testemunhas em todos os ambientes), desde que ao menos os cultivares em teste estejam balanceados nos vários locais é proposto por Lin \& Binns (1988). A medida da superioridade geral dos cultivares para as informações de interação cultivares $\mathrm{x}$ locais é definida como o quadrado médio da distância entre a resposta dos cultivares e a resposta máxima média sobre todos os locais. Então, dessa forma, a resposta máxima é o limite superior em cada local, um quadrado médio pequeno significaria superioridade geral do cultivar em teste. As vantagens do método proposto são:

1. As testemunhas fornecem somente uma resposta máxima razoável para cada local e não são necessárias para avaliar os cultivares em teste; desse modo, não é necessária a presença das testemunhas em todos os locais, permitindo uma maior flexibilidade ao melhorista na escolha de cultivares localmente adaptados como testemunhas mais representativas, sem aumentar indevidamente o tamanho do teste regional.

2. A medida da superioridade geral baseia-se somente em um parâmetro, simplificando o processo de seleção consideravelmente. Um parâmetro auxiliar para a interação pode ser usado para indicar a perda de adaptação geral. 
3. A diferença entre a média da máxima resposta sobre todos os locais e a média do melhor cultivar fornece informações úteis, como por exemplo sobre quantos cultivares são necessários para conseguir produtividade ótima para todas as regiões.

4. A adaptabilidade específica de um cultivar pode ser identificada por meio da máxima resposta do cultivar em teste num dado ambiente.

Este método permite a exclusão de cultivares com alta interação $\mathrm{G} \times \mathrm{E}$ presente, o que dificultaria a comparação mais precisa das médias dos cultivares.

Os números de experimentos a serem realizados para se obter dados sobre o comportamento de genótipos de soja também representa uma informação útil ao melhorista, de modo a possibilitar um melhor emprego dos recursos econômicos e de mão-de-obra disponiveis. Analisando as diferenças entre 43 experimentos de avaliação de linhagens de soja em 16 locais do Estado de Minas Gerais em comparação a apenas duas localidades e três épocas de semeadura para a produtividade de grãos, adaptabilidade e estabilidade fenotípica, Sakiyama et al. (1988) obtiveram resultados que indicam uma boa eficiência do uso de apenas dois locais e três épocas. Tais resultados facilitam a execução do programa de melhoramento, pois diminuem o número elevado de linhagens a serem avaliadas em experimentos preliminares, além de reduzir o número de locais. Estes resultados são válidos desde que haja uma escolha adequada de linhagens ou genótipos a serem conduzidos, sendo que para novas localidades estudos devem ser realizados.

Aparentemente os genótipos altamente produtivos são mais sensiveis às variações ambientais, fato observado por Dashiell et al. (1994) em genótipos de soja cultivados em cinco locais na Nigéria, onde a alta interação $G \times E$ influenciou também na baixa herdabilidade da produtividade de sementes. 


\subsubsection{Fatores ambientais atuando na interação $G X E$}

\subsubsection{Efeito da temperatura na interação}

Pesquisando a tolerância de cultivares de soja ao frio, Schmid \& Keller (1980) obtiveram em câmaras para alternação de calor e frio, redução na produtividade de um cultivar alemão enquanto que nos cultivares húngaros ocorreu aumento da produtividade na condição de menor temperatura empregada. Em casa-de-vegetação, com estresses causados por frio nos estádios V1, V3 e início de florescimento, todos os cultivares foram capazes de compensar o estresse por 10 dias.

Os cultivares de soja de origem tropical e os de origem temperada podem reagir de modo diferenciado ao ambiente. Lawn \& Hume (1985) testaram 12 linhagens de soja às mudanças de regime térmico para avaliar o comportamento destas a baixas temperaturas durante o desenvolvimento reprodutivo precoce. Obtiveram respostas grandes entre linhagens na sensibilidade para formação de vagens em temperaturas noturnas baixas. As linhagens de adaptação tropical foram mais sensiveis do que as temperadas, contudo existiram variações entre as linhagens dentro dos grupos tropical e temperado. A linhagem mais sensível (tropical) não formou vagens em temperaturas noturnas de 8 a $12^{\circ} \mathrm{C}$, enquanto a menos sensivel (temperada) formou vagens em todos os regimes térmicos. A maior sensibilidade das linhagens tropicais foi consistente com experiências de campo no norte da Austrália e sugere que estratégias para a estação seca (inverno) dos trópicos de baixa latitude, particularmente para áreas de elevada altitude, necessitam o desenvolvimento de linhagens com menor sensibilidade ao efeito ambiental representado pelas temperaturas noturnas baixas, pois existe clara variação genotípica na soja em termos de sensibilidade do crescimento reprodutivo precoce a baixas temperaturas noturnas, fase esta mais sensível à temperatura do que a fase de crescimento vegetativo.

O efeito da temperatura sobre a formação e maturidade das sementes afetando a expressão de impermeabilidade da casca, foi estudado por Tinius et al. (1989); os resultados indicaram que os genótipos interagiram de maneira diferente aos regimes de 
temperatura, o que sugere um certo nível de expressão variável para o caráter em diferentes ambientes; desse modo, as seleções para permeabilidade poderiam depender de um ambiente específico.

Unander et al. (1986) cultivaram genótipos de soja em cinco locais por dois anos, visando-se examinar o efeito do ambiente de origem das sementes na germinação em baixas temperaturas; comparar genótipos do meio-oeste americano e de outros países para tolerância ao frio; determinar se a concentração de óleo ou proteína, tamanho das sementes ou data de colheita foram correlacionados com dados de germinação no frio e comparar o desenvolvimento de genótipos em câmara-fria e em semeaduras precoces no campo. Amostras de sementes desses plantios foram testadas para a taxa de germinação a $10^{\circ} \mathrm{C}$; os resultados obtidos por análises de índices de germinação indicaram efeitos altamente significativos de interações $\mathrm{G} \times \mathrm{E}$ para cada ano. O subgrupo de acessos estrangeiros foi mais consistente na germinação com tolerância ao frio do que o norte-americano e somente a concentração de óleo mostrou uma pequena correlação positiva e significativa com germinação no frio sendo, portanto, o que mais interagiu com o ambiente frio.

\subsubsection{Efeito da época de semeadura na interação}

Uma semeadura mais precoce é importante, para se escalonar a colheita e aumentar o número de opções disponíveis para culturas subsequentes. Contudo, o florescimento prematuro de um cultivar em semeadura antecipada pode reduzir a proteção do solo por menor fechamento vegetal no florescimento ou no início da granação. Kane \& Grabau (1992) conduziram um estudo para avaliar o melhor grupo de maturidade para o sistema de cultivo antecipado e para relacionar os parâmetros de cultivo, desenvolvimento e ambientes para a produtividade. A duração do período vegetativo, formação de vagens e granação foram menores nos cultivares precoces utilizados, mas também ocorreu interação com o ambiente. Os cultivares utilizados do grupo de maturidade I e II apresentaram maior sensibilidade às chuvas no período 
vegetativo e surgimento das vagens e para variações de temperatura no processo de granação, mostrando uma correlação positiva com o aumento de chuvas durante o desenvolvimento vegetativo e a formação de vagens.

Um comportamento interessante dos diversos grupos de maturidade pode ser observado no trabalho de Boote (1981) que analisou vários grupos de maturação; cultivares do grupo de maturidade VI, VII e VIII sofreram uma grande influência ambiental dos dias longos de maio, junho e julho da Flórida, não completando o desenvolvimento reprodutivo em setembro e outubro. Cultivares do grupo de maturidade 000 e I tiveram florescimento e maturidade precoces e baixa produtividade; cultivares do grupo II, III e IV tiveram maturidade tardia, maior altura da planta e maior produtividade, reflexo do maior periodo de granação. Cultivares do grupo V maturaram muitas de sua vagens, mas retiveram muitas folhas verdes e apresentaram qualidade de semente ruim, indicando diferentes interações dos grupos de maturidade com o comprimento do dia.

Os curtos fotoperíodos associados com plantas precoces têm mostrado ser a causa do florescimento prematuro, ou seja, a planta de soja não forma a estrutura adequada para que ocorra o máximo de desenvolvimento das vagens, tanto em número quanto em tamanho; com isso, a produtividade dos cultivares de maturidade precoce pode ser reduzida devido à menor interceptação luminosa, em resposta à menor massa vegetal presente (Board \& Hall, 1984).

Um experimento cujo objetivo foi comparar a magnitude das interações G x E dentro e entre regiões com graus variáveis de adaptação para produtividade foi conduzido por Pfeiffer et al. (1995). Os resultados obtidos dentro de dois estados (Kentucky e Minnesota) apresentaram interação G x E significativa, enquanto que para a interação genótipos $x$ estados não houve resultado significativo. As interações entre e dentro dos estados apresentaram todos os resultados significativos para teor de proteína e concentração de óleo nas sementes. Houve desempenho similar dos genótipos entre os estados, levando os autores a não recomendarem o início de um programa novo de 
melhoramento para genótipos especialmente adaptados a um sistema de produção precoce no sul dos EUA, apesar da interação presente. Esta recomendação pode não ser válida, se condições especiais ocorrerem numa região alvo em relação à região de origem do cultivar. A mesma conclusão foi obtida por Pfeiffer (1987) comparando genótipos em cultivos de épocas normal e tardia com o objetivo de avaliar diferentes critérios de seleção para a identificação dos melhores genótipos para produção fora de época, em rotação após uma outra cultura granífera. Contudo esses resultados diferem daqueles obtidos por outros experimentos conduzidos por Beaver \& Johnson (1981), Boquet et al. (1982), Carter \& Boerma (1979) e Parker et al. (1981), que têm mostrado interação significativa de genótipos com as datas de semeadura num nivel em que se torna necessário o desenvolvimento de cultivares específicos para esse uso. A diferença pode estar no pequeno número de cultivares (menos de dez) nesses experimentos e de 26 no conduzido por Pfeiffer (1987), pois quando um pequeno número de genótipos são comparados, uma grande mudança na classificação de um único genótipo pode influenciar a conclusão estatística sobre a interação $\mathrm{G} \times \mathrm{E}$. O uso de genótipos ao acaso elimina o problema de comparação num segundo tipo de ambiente. Essa mesma tendência tem sido observada com estudos de interação genótipos $\mathrm{x}$ espaçamentos de linhagens em soja (Cooper, 1977 e Lehman \& Lambert, 1960).

Num estudo para avaliar cultivares do grupo de maturidade III a VII, semeados em meados de abril e de maio sem irrigação, avaliando-se caracteres referentes a data de maturidade, altura da planta, acamamento, produtividade de sementes, quebramento de sementes, observou-se que a produtividade média foi maior para a semeadura em abril comparado com a de maio de 1987. Já em 1988 não houve diferença na produtividade. $\mathrm{O}$ plantio precoce em abril afetou a maturidade dos cultivares do grupo III com maior intensidade e menor para os cultivares tardios, sendo a maior vantagem da semeadura de cultivares precoces em abril no nordeste de Arkansas. Todos os cultivares cresceram menos quando semeados em abril; o acamamento aumentou na semeadura de maio comparada com a de abril. Em resumo, os autores discutem que a data de semeadura tem uma grande influência na data de maturidade de cultivares precoces 
comparados com os tardios. A produtividade de sementes não teve grandes diferenças na média sobre ambos os anos (May et al., 1989).

\subsubsection{Efeito da altitude na interação}

Comparando o sistema de consorciação com monocultivo da soja em vários ambientes (altitudes), Gupta et al. (1981) obtiveram desempenhos distintos em cada experimento para os caracteres: número de sementes ardidas; peso de cem sementes; volume de cem sementes; densidade das sementes; comprimento do peciolo e do internódio da planta; altura da planta e número de dias para a maturidade. Ao se passar de altas altitudes para baixas foi observado um aumento da porcentagem de sementes ardidas, atrapalhando a qualidade de cozimento e possivelmente, dificultando a adaptação da cultura de paises subtropicais para tropicais; além disso a pluviosidade e as temperaturas diurnas e noturnas na fase de crescimento, apresentaram relação com a produtividade e outros caracteres. A pluviosidade na fase reprodutiva indicou ser o fator de maior importância sobre a produtividade.

\subsubsection{Efeito da irrigação na interação}

As condições hídricas do solo possuem uma grande importância para o desenvolvimento de qualquer cultura, mas não se sabe se causam algum efeito na precisão estatística dos experimentos. Para resolver essa dúvida, Bowman et al. (1993) realizaram experimentos envolvendo presença ou não de irrigação de 1987 a 1990 . Os resultados obtidos dentro de cada ano indicaram a existência de interação manejo de água $\mathrm{x}$ cultivar em metade dos grupos de soja estudados, porém na análise conjunta de anos essa interação não foi significativa. Os testes de irrigação permitiram melhor distinção de aproximadamente metade dos grupos estudados de soja; os dados sugerem que os testes estatísticos não tiveram melhor precisão que os obtidos em condições de seca; isso significa que a irrigação deve ser usada com o propósito de assegurar que não ocorram perdas de plantas e com isso perdas de dados de uma ou mais parcelas. Esse estudo 
também indicou que as interações criadas com testes irrigados requerem que os dados de irrigação e os de seca sejam obtidos separadamente e não no mesmo campo.

\subsection{Teste de Wricke}

Para se estudar o efeito da interação de genótipos com ambientes existem diversas metodologias, destacando-se aqueles apresentados por Eberhart \& Russell (1966), Shukla (1972), Tai (1971) e Wricke (1965). O conceito agronômico refere-se às alterações de desempenho dos genótipos ao se mudar o ambiente, pois cada material genético possui capacidade diferente para contrabalançar qualquer alteração que ocorra no ambiente onde se encontra.

O teste de ecovalência apresentando por Wricke (1965) é baseado na distribuição do efeito da interação $\mathrm{G} \times \mathrm{E}$ para cada genótipo individualmente. Os genótipos mais instáveis apresentam maiores contribuições para o efeito da interação e, portanto, maiores valores de ecovalência; já os genótipos mais estáveis contribuem menos e, com isso, tem-se menores valores de ecovalência para estes.

As estimativas de ecovalência para serem representativas necessitam no mínimo três ou quatro anos de avaliações. As interações entre genótipos e ambientes (genótipo $\mathrm{x}$ local, genótipo $\mathrm{x}$ ano, genótipo $\mathrm{x}$ época) determinadas pela análise de variância de uma série de experimentos de genótipos são distribuídas individualmente para cada genótipo. Vários experimentos indicaram que repetições em diversos locais é um procedimento mais efetivo para a estimativa da ecovalência do que repetições em vários anos; a ecovalência é independente do número de genótipos testados, podendo-se avaliar poucos materiais sem problemas (Fuchs, 1979).

Comparando-se os resultados obtidos ao se aplicar a metodologia de Wricke (1965) aos obtidos pela de Eberhart \& Russell (1966) e Tai (1971), pode-se observar que foram muito semelhantes para a produtividade de grãos de trigo. Todos os testes conseguiram identificar os materiais mais produtivos como os menos estáveis 
(Carvalho et al., 1983). Os métodos demonstraram similaridade entre o desempenho de um genótipo com um ambiente em particular.

Os testes de Wricke (1965), Eberhart \& Russell (1966), Tai (1971) e de Shukla (1972) foram correlacionados positivas e significativamente, sendo isto indicativo de que todos foram similares em fornecer as estimativas de estabilidade para os materiais testados, conforme as estimativas obtidas nos trabalhos de Vega (1984), Yue et al. (1996), Yue et al. (1997). Adicionalmente, Yue et al. (1997) observaram que a comparação dos testes baseando-se em apenas um ano de observações não é confiável, sendo necessário o uso de mais de um ano para tornar a comparação mais robusta. 


\section{MATERIAL E MÉTODOS}

\subsection{Material genético}

O material genético envolvido nesta pesquisa compreendeu 24 progênies na geração $F_{9: 4}$, selecionadas na geração $F_{7: 4}$ de 15 topocruzamentos de soja (Glycine max (L.) Merrill). Os tratamentos foram compostos pela repetição das melhores plantas e quando não foi possível compor toda a parcela, foram adicionadas plantas de outra progênie do mesmo topocruzamento. Foram empregadas quatro testemunhas comuns: IAC PL-1, Tamba, Late Giant e Nimame; estas foram escolhidas devido as suas características apropriadas ao consumo humano direto, pois são cultivares de soja tipo alimento com sementes grandes. A identificação de todos os tratamentos é apresentada na Tabela 1.

As 24 progênies foram selecionadas de topocruzamentos de 41 linhagens exóticas de sementes grandes (soja tipo alimento) com dois parentais adaptados (Doko e FT-2) com sementes de tamanho médio (tipo grão). As linhagens tipo alimento participaram como parentais femininos, contribuindo, portanto, também com o citoplasma para os híbridos obtidos. Estes parentais são considerados exóticos por serem introduções de outros países, não tendo participado dos programas de melhoramento para produtividade de grãos em seus locais de origem; tais parentais também não mostraram adaptação às condições brasileiras (Santos, 1988), tendo apresentado grande sensibilidade ao fotoperiodo em baixas latitudes, além da qualidade fisiológica das sementes ser ruim (perda rápida da capacidade de germinação e do vigor da plântula).

Os parentais masculinos utilizados foram dois cultivares brasileiros tipo grão (Doko e FT-2), ambos com alta qualidade fisiológica de sementes, produtividade de grãos relativamente alta nos locais em que são recomendados, além de 
apresentarem divergência genética relativamente alta entre eles, conforme os dados obtidos nas análises de genealogia por Vello et al. (1988). Espera-se a obtenção de híbridos com menor grau de parentesco, podendo-se com isso também ampliar a base genética do germoplasma disponivel; além disso, 'Doko' apresenta período juvenil longo e ciclo tardio, enquanto que 'FT-2' apresenta periodo juvenil curto e ciclo precoce.

As gerações anteriores destes topocruzamentos foram pesquisadas por Destro (1991), Pacova (1992) e Yokomizo (1994).

\subsection{Ambiente experimental}

A pesquisa foi conduzida em áreas experimentais do Departamento de Genética/ESALQ/USP, em Piracicaba, localizada a $22^{\circ} 42^{\prime} 33^{\prime \prime}$ de latitude sul e $47^{\circ} 38^{\prime} 00^{\prime \prime}$ de longitude oeste e $540 \mathrm{~m}$ de altitude. Foram considerados três ambientes:

a) Piracicaba-verão (PV), com semeadura em 15 de novembro de 1996;

b) Piracicaba-outono (PU), com semeadura em 07 de março de 1997,

c) Anhembi-verão (AV), com semeadura em 17 de novembro de 1996.

O local Piracicaba possui relevo muito ondulado, artificialmente amenizado com o uso de curvas de níveis e terraços de retenção e solo tipo terra roxa estruturada eutrófica. Localiza-se na área experimental do Departamento de Genética, dentro da sede ESALQ.

O local Anhembi corresponde à Estação Experimental Anhembi distante cerca de $60 \mathrm{~km}$ da sede ESALQ, possui relevo plano e solo tipo aluvial distrófico, com textura médio arenosa. Representa um tipo de solo comumente encontrado nos cerrados brasileiros, tendo a acidez neutralizada pela aplicação de calcário dolomítico nos dois anos anteriores aos experimentos. 
Nos três ambientes foi cultivada aveia preta (Avena strigosa Sckeb) no inverno anterior aos experimentos, incorporada por ocasião do florescimento. A adubação também foi uniforme nos três ambientes, utilizando-se adubo de fórmula 4:20:20 na base de 25 gramas por metro linear de sulco, ou seja $500 \mathrm{~kg} / \mathrm{ha}$. As sementes foram previamente tratadas com fungicida (Thiabendazole, MSD, $100 \mathrm{~g} / \mathrm{kg}$ ) em pó. $\mathrm{O}$ controle de ervas daninhas foi feito com o uso de herbicidas de pré-emergência (Imazaquin, 0,7 1/ha e Trifluralin, 1,8 $1 / \mathrm{ha}$ ) e quando necessário foram usados herbicidas de pós-emergência (Clorimuron etil, $70 \mathrm{~g} / \mathrm{ha}$ e Clethodim, 0,4 l/ha), além de capinas manuais quando as plantas alcançaram um estádio de desenvolvimento tal que o pulverizador não pôde ser empregado. O controle de insetos (percevejos) foi realizado com os inseticidas: Monocrotophos $(0,375 \mathrm{l} / \mathrm{ha})$ e Endosulfon $(1,25 \mathrm{l} / \mathrm{ha})$ quando a infestação atingia os níveis recomendados de controle.

\subsection{Delineamento experimental}

Os experimentos foram conduzidos em condições de campo no delineamento de blocos ao acaso com duas repetições estratificadas em conjuntos com testemunhas comuns. Cada repetição foi formada por dois conjuntos experimentais contendo 12 linhagens experimentais e quatro testemunhas em cada um. A parcela experimental foi constituída por duas fileiras de $2,5 \mathrm{~m} \times 1,0 \mathrm{~m}$, contendo dez covas de plantas individuais espaçadas $0,5 \mathrm{~m}$ dentro de cada fileira; entre duas parcelas contínuas foi deixado o espaço de $1,00 \mathrm{~m}$.

\subsection{Croqui do experimento por local}

\begin{tabular}{|c|} 
Repetição 1 \\
\hline Conjunto 1 : \\
progênies de 1 a 12 (sorteadas) \\
e \\
testemunhas comuns \\
\hline Conjunto $2:$ \\
progênies de 13 a 24 (sorteadas) \\
e \\
testemunhas comuns \\
\hline
\end{tabular}

\begin{tabular}{|c|} 
Repetição 2 \\
\hline Conjunto $1:$ \\
progênies de 1 a 12 (sorteadas) \\
e \\
testemunhas comuns \\
\hline Conjunto $2:$ \\
progênies de 13 a 24 (sorteadas) \\
e \\
testemunhas comuns \\
\hline
\end{tabular}




\subsection{Caracteres avaliados}

NDM - número de dias para a maturidade, contados desde a emergência até a maturação (estádio $\mathrm{R}_{8}$ da escala de Fehr \& Caviness, 1977);

APM - altura da planta na maturidade, em centímetros;

AC - acamamento, avaliado na maturidade por escala de notas visuais, variando de nota 1 (planta ereta) até 5 (planta totalmente deitada);

VA - valor agronômico, avaliado na maturidade, correspondendo a um indice global incluindo produtividade, vigor geral da planta, sanidade, retenção de folhas, presença/ausência de haste verde, utilizou-se uma escala de notas visuais variando de nota 1 (planta ruim) até 5 (planta ótima);

LVV - largura visual das vagens, avaliada na maturidade, através de uma escala de notas, variando de nota 1 (vagens muito estreitas) até 5 (vagens muito largas), segundo o esquema 1 anexo.

PG - produtividade de grãos, em gramas por planta;

PCS - peso de cem sementes, em gramas; avaliado através de uma amostra de cem sementes de cada planta colhida; nas plantas que não produziram cem sementes, o PCS foi estimado através da seguinte equação:

$$
\mathrm{PCS}=\left(\mathrm{PG}_{\mathrm{i}} \times 100\right) / \mathrm{n}_{\mathrm{i}}
$$

Sendo:

$\mathrm{PG}_{\mathrm{i}}$ : produtividade da planta em gramas; $n_{i}$ : número de sementes da planta;

$\mathrm{Na}$ avaliação dos caracteres AC, VA e LVV, também foram atribuídas notas intermediárias de 0,5 (p.ex. 1,$5 ; 2,5 ; 3,5 ; 4,5$ ). Para estes caracteres, os dados foram transformados por $\sqrt{\mathrm{x}+0,5}$ antes da realização das análises estatísticas, visando-se aproximar da distribuição normal, viabilizando-se a estimativa de variâncias entre plantas individuais dentro de parcelas 


\subsection{Análises estatístico-genéticas}

\subsubsection{Considerações iniciais}

Com a finalidade de se verificar a existência de efeitos entre os conjuntos experimentais, inicialmente realizaram-se as análises da variância individual e posteriormente a conjunta dos três ambientes somente com os dados das quatro testemunhas comuns. A seguir foram realizadas análises de variância dos tratamentos principais (progênies) com a finalidade de se detectar diferenças entre as progênies em cada ambiente. As análises estatístico-genéticas foram realizadas com o auxílio dos programas computacionais GENES 5, SAEG, desenvolvidos pela Universidade Federal de Viçosa e SAS desenvolvido pelo SAS Institute Inc., Cary, North Carolina, USA.

\subsubsection{Médias e variâncias}

Foram estimadas as médias e as variâncias fenotípicas dos dados obtidos ao nível de plantas individuais (covas) para cada caráter e progênie.

A média foi estimada pela divisão da soma dos valores individuais pelo número de plantas existentes por ambiente $(i=1, \ldots, n$; sendo $n=$ até 20 covas $)$; a variância fenotípica entre plantas foi calculada pela soma das variâncias ponderadas pelo número de plantas $(\mathrm{i}=1, \ldots, \mathrm{n}$; sendo $\mathrm{n}=$ até 10 plantas $)$ de cada repetição $\mathrm{e}$ dividida pelo número total de repetições $(j=1 ; 2$ repetições). A variância para cada repetição foi estimada por:

$$
\mathrm{Vj}=\frac{\sum(\mathrm{yi}-\overline{\mathrm{y}})^{2}}{\mathrm{n}-1}
$$

sendo $\mathrm{i}=1, \ldots, \mathrm{n} ; \mathrm{n}=$ até 10 covas de plantas individuais;

$\mathrm{j}=1 ; 2$. 


\subsubsection{Análise de Variância}

Inicialmente foram obtidas as médias das parcelas, dividindo-se a soma dos valores das plantas pelo número de plantas (até 10), para cada repetição e cada caráter. A partir das médias das parcelas foi realizada a análise de variância por ambiente, objetivando-se detectar possíveis diferenças entre as progênies. Estas análises individuais também permitem a comparação dos quadrados médios dos resíduos dos três ambientes; admitiu-se um limite dado pelo quociente igual a sete entre o maior e o menor quadrados médios residuais das análises de variância individuais (PimentelGomes, 1991), para uma precisão experimental não discrepante entre os experimentos; contrariamente, quocientes acima de sete tornariam necessário um ajuste dos graus de liberdade, para que o teste $\mathrm{F}$ da análise conjunta seja confiável.

Para cada ambiente individualmente o modelo adotado foi adaptado de Vencovsky (1992a) e de Cruz \& Regazzi (1994):

$$
\mathbf{Y}_{\mathbf{i j k}}=\mu+\mathbf{G}_{\mathbf{i}}+\mathbf{R} \mathbf{j}+(\mathbf{C} / \mathbf{R}) \mathbf{j k}+\mathbf{e}_{\mathbf{i j k}}
$$

sendo que:

Gi : efeito do i-ésimo genótipo;

$\mathbf{R j}$ : efeito da j-ésima repetição;

(C/R)jk : efeito do k-ésimo conjunto dentro da j-ésima repetição;

eijk : erro aleatório.

O seguinte modelo para a análise conjunta, segundo Vencovsky (1992a), foi adotado:

$$
\mathbf{Y}_{\text {ceik }}=\mu+\mathbf{G}_{\mathbf{i}}+\mathbf{E}_{\mathrm{e}}+\mathbf{R}_{\mathbf{k}}+(\mathbf{C} / \mathbf{R}) \mathbf{E}_{\mathbf{c e k}}+\mathbf{G E}_{\mathrm{ie}}+\mathbf{e}_{\text {ceik }}
$$

sendo que:

$\mathbf{G}_{\mathbf{i}}$ : efeito do i-ésimo tratamento;

$\mathbf{E}_{\mathbf{j}}$ : efeito do e-ésimo ambiente;

$\mathbf{R}_{\mathbf{k}}$ : efeito da k-ésima repetição; 
$(\mathbf{C} / \mathbf{R}) \mathbf{E}_{\text {cek }}$ :efeito do c-ésimo conjunto dentro da k-ésima repetição no e-ésimo ambiente;

$\mathbf{G E}_{\text {ei }}$ efeitos da interação de primeira ordem entre tratamentos e ambientes;

e $\mathbf{e}_{\text {ceik }}$ : erro aleatório.

Considerou-se o seguinte quadro da análise de variância, com efeitos fixos de ambientes e tratamentos:

\begin{tabular}{|c|c|c|}
\hline FV & GL & $\mathrm{E}(\mathrm{QM})$ \\
\hline Ambiente (E) & $\mathrm{e}-1$ & $\sigma^{2}+t V_{C}+c t k V_{E}$ \\
\hline Tratamentos $(\mathrm{G})$ & $\mathrm{t}-1$ & $\sigma^{2}+\operatorname{cek} V_{G}$ \\
\hline Progênies (Pro) & $\mathrm{i}-1$ & $\sigma^{2}+\operatorname{cek} V_{\text {Pro }}$ \\
\hline Testemunhas (Te) & $j-1$ & $\sigma^{2}+\operatorname{cek} V_{T e}$ \\
\hline Pro vs Te & 1 & $\sigma^{2}+\operatorname{cek} V_{\text {To vs Te }}$ \\
\hline$G \times E$ & $(\mathrm{t}-1)(\mathrm{e}-1)$ & $\sigma^{2}+\mathrm{ck} \mathrm{V}_{\mathrm{G} \times \mathrm{E}}$ \\
\hline Pro $x E$ & $(\mathrm{i}-1)(\mathrm{e}-1)$ & $\sigma^{2}+\mathrm{ck} \mathrm{V}_{\mathrm{ToxE}}$ \\
\hline Te $x E$ & $(j-1)(e-1)$ & $\sigma^{2}+\mathrm{ck} \mathrm{V}_{\mathrm{TexE}}$ \\
\hline Grupos $x E$ & $1(\mathrm{e}-1)$ & $\sigma^{2}+$ ck $V_{\text {Grupos } x E}$ \\
\hline $\mathrm{C} / \mathrm{R} / \mathrm{E}$ & (c-1)ek & $\sigma^{2}+t V_{C}$ \\
\hline $\mathrm{R} / \mathrm{E}$ & $(\mathrm{k}-1) \mathrm{e}$ & $\sigma^{2}+t V_{C}+\operatorname{cet} \sigma_{R}^{2}$ \\
\hline Resíduo & $\{(\mathrm{k}-1)[(\mathrm{i}-1)+(\mathrm{j}-1)]+(\mathrm{c}-1)(\mathrm{jk}-1)\} \mathrm{e}$ & $\sigma^{2}$ \\
\hline
\end{tabular}

sendo:

c. 1 a 2 conjuntos;

Grupos: 2 (Progênies e testemunhas)

e: 1 a 3 ambientes;

i : 1 a 24 progênies;

j: 1 a 4 testemunhas;

$\mathrm{k}: 1$ a 2 repetições;

$\mathrm{t}: 1$ a 28 tratamentos.

Os demais componentes das fontes de variação foram desconsiderados e incluídos no resíduo. 


\subsubsection{Contribuição de cada fonte de variação na diversidade total dos dados para cada caráter}

$$
\mathrm{R}_{1}^{2}=\frac{\mathrm{GL}_{1} \cdot \mathrm{QM}_{1}}{\mathrm{GL}_{\mathrm{i}} \cdot \mathrm{QM}_{\mathrm{i}}+\mathrm{GL}_{\mathrm{j}} \cdot \mathrm{QM}_{\mathrm{j}}+\mathrm{GL}_{\mathrm{k}} \cdot \mathrm{QM}_{\mathrm{k}}}
$$

sendo:

$\mathrm{R}_{1}^{2}$ : contribuição da variação l na variação total;

$\mathrm{QM}_{\mathrm{I}}$ : quadrado médio da fonte de variação a ser avaliada $(\mathrm{G}, \mathrm{G} \times \mathrm{E}$ ou Resíduo);

$\mathrm{QM}_{\mathrm{i}}$ : quadrado médio de tratamentos;

$\mathrm{QM}_{\mathrm{j}}$ : quadrado médio da interação $\mathrm{G} \times \mathrm{E}$;

$\mathrm{QM}_{\mathrm{k}}$ : quadrado médio do resíduo;

$\mathrm{GL}_{\mathrm{i}}$ : graus de liberdade de tratamentos;

$\mathrm{GL}_{\mathrm{j}}$ : graus de liberdade da interação $\mathrm{G} \times \mathrm{E}$;

$\mathrm{GL}_{\mathrm{k}}$ : graus de liberdade do resíduo.

Para a estimação da contribuição de cada fonte de variação na diversidade total dos dados não serão considerados os efeitos de ambientes e de blocos (repetições) dentro de ambientes.

Esses cálculos permitem estimar a porcentagem que cada fonte de variação representa da variação total dos dados para cada caráter estudado, multiplicando-se o $\mathrm{R}_{1}^{2}$ por 100 .

\subsubsection{Desempenho médio das progênies}

Para se avaliar o desempenho médio de cada progênie, em relação à média das testemunhas ou à média geral de todos as progênies, utilizou-se a seguinte equação:

$$
\operatorname{Dm}_{\mathrm{i}}=\left(\frac{\overline{\mathrm{x}}_{\mathrm{i}}-\overline{\mathrm{x}}_{\text {padrão }}}{\overline{\mathrm{x}}_{\text {padrão }}}\right) \cdot 100
$$

sendo: $\quad \mathrm{Dm}_{\mathrm{i}} \quad$ : desempenho médio da i-ésima progênie; 
$\overline{\mathrm{x}}_{\mathrm{i}} \quad$ : média da progênie para o caráter em avaliação;

$\overline{\mathrm{x}}_{\text {padrão }}$ : média do padrão que está sendo utilizado (média das testemunhas ou média geral de progênies).

\subsubsection{Teste de SCOTT \& KNOTT e histograma para agrupamento de genótipos}

Nos caracteres em que foram observadas diferenças significativas para o efeito de tratamentos pelo teste $F(P<0,05)$, promoveu-se o agrupamento de médias pelo método de Scott \& Knott (1974); para cada ambiente separadamente e posteriormente para os três ambientes em conjunto.

Por este método as médias de tratamentos são classificadas em grupos, sem sobreposição, através das diferenças significativas existentes, sendo indicado para experimentos com delineamento balanceado e com número de tratamentos superior a 20.

O critério de classificação baseou-se num processo hierárquico ou de ramificação, dividindo-se as médias de tratamentos em dois grandes grupos e, assim, sucessivamente em novos subgrupos, cada novo subgrupo contendo padrões de similaridade em seu conjunto de médias. O processo de divisões encerrou-se quando tentou-se dividir um subgrupo em dois novos e estes não apresentaram diferenças significativas. O método de divisão adotado foi o de Edwards \& Cavali-Sforza (1965) que consiste em medir a similaridade das médias individuais de tratamentos dentro dos grupos pela soma dos mínimos quadrados (SQ) dos indivíduos; para maiores detalhes ver Scott \& Knott (1974) e Pacova (1992).

O procedimento adotado para o teste de Scott-Knott é descrito a seguir, considerando:

$$
\lambda=\pi \mathrm{B}_{0} /\left[2 \hat{\sigma}_{0}^{2}(\pi-2)\right]
$$

sendo:

$\lambda$ : teste da razão de verossimilhança; 
$\pi: 3,14159 \ldots$;

$\mathbf{B}_{0}$ : valor máximo da soma de quadrados entre grupos obtidos sobre todas as possíveis divisões dos $t$ tratamentos em 2 grupos

$\hat{\sigma}_{0}^{2}=\left[\Sigma\left(\overline{\mathbf{x}}_{\mathbf{i} .}-\overline{\mathbf{x}}_{. .}\right)^{2}+v \mathbf{s}_{\mathbf{x}}^{2}\right] /(\mathbf{t}+v)$

$\sigma_{\mathbf{0}}^{2}$ : estimador de máxima verossimilhança;

$\overline{\mathbf{x}}_{\mathbf{i}}$ : média do i-ésimo tratamento

$\mathbf{t}$ : número de médias de tratamentos sendo divididas

$\mathbf{S}_{\mathbf{X}}^{\mathbf{2}}$ : variância da média de tratamento $\left(\mathrm{QM}_{\mathrm{erro}} / \mathrm{r}\right)$

$v$ : graus de liberdade do quadrado médio do erro;

r: número de observações em cada média;

A distribuição de $\lambda$ foi então comparada a uma de distribuição $\mathrm{X}^{2}$ com graus de liberdade para $V_{0}$, sendo:

$$
\mathrm{V}_{0}=\mathrm{t}(\pi-2)
$$

Quando o $\lambda$ calculado foi menor que o correspondente $\mathrm{X}^{2}$ tabulado ao nivel de significância escolhido, todas as médias foram consideradas homogêneas; caso contrário, ou seja, se $\lambda$ foi maior que o valor tabulado, os dois grupos avaliados não diferiram significativamente entre si.

Com a classificação de cada genótipo (tratamento) nos três ambientes testados foi construído um histograma para os caracteres PG, PCS e VA, no qual cada genótipo apresenta uma coluna envolvendo o grupo de classificação que obteve em cada ambiente. 


\subsubsection{Correlações genéticas e fenotípicas}

Os caracteres foram combinados dois a dois e a seguir determinaramse as correlações genéticas $\left(r_{G}\right)$ e fenotípicas $\left(r_{F}\right)$ de Pearson entre eles, para cada grupo de genótipos, ou seja, para o grupo das progênies e para o grupo das testemunhas. Para as correlações genéticas as estimativas foram obtidas para os três ambientes combinados e para as fenotípicas foram obtidas individualmente por ambiente e também com os três ambientes combinados, conforme as seguintes equações (Vencovsky, 1992b):

Correlação fenotípica:

$$
r_{F(X Y)}=\frac{\operatorname{COV}_{F(X Y)}}{\sqrt{V_{F(x)} V_{F(y)}}}
$$

sendo:

$\mathrm{r}_{\mathrm{F}(\mathrm{XY})}$ : correlação fenotípica entre os caracteres x e y;

$\operatorname{cov}_{F(x, y)}$ : produto médio de tratamentos para os caracteres $x$ e y envolvidos;

$V_{F(x)}$ e $V_{F(y)}$ : variância fenotípica de tratamentos para os caracteres $x$ e $y$, respectivamente.

$$
r_{G(X Y)}=\frac{\operatorname{COV}_{G(X Y)}}{\sqrt{V_{G(x)} V_{G(y)}}}
$$

sendo:

$r_{G(X Y)}$ : correlação genotípica entre os caracteres x e y; $\operatorname{cov}_{G(x, y)}$ : produto médio de tratamentos para os caracteres $x$ e y envolvidos; $V_{G(x)}$ e $V_{G(y)}$ : variância genotípica de tratamentos para os caracteres $x$ e $y$, respectivamente. 


\subsubsection{Teste de Wricke para avaliação da contribuição de cada genótipo na interação G x E}

A ecovalência, termo empregado para a contribuição relativa do i-ésimo genótipo na interação $\mathrm{G} \times \mathrm{E}$ geral, foi estimada com o auxilio da seguinte equação:

$$
e c o_{i}=r \sum_{j}\left(Y i j-\bar{Y}_{i .}-\bar{Y} \cdot j+\bar{Y}_{. .}\right)^{2}
$$

em que:

eco $:$ contribuição do i-ésimo genótipo para a $\mathrm{SQ}_{\mathrm{GxE}}$ total

r: número de repetições

Yij: média do genótipo i no ambiente $\mathrm{j}$;

$\bar{Y} i$. :média do genótipo $i$;

$\bar{Y} . \mathrm{j}:$ média do ambiente $\mathrm{j}$;

$\bar{Y}$..: média geral.

A metodologia proposta por Wricke (1965) apresenta as mesmas vantagens e desvantagens da metodologia proposta por Plaisted \& Peterson (1959), podendo-se dizer que apresentam uma certa relação, pois as estimativas de Wricke são obtidas pela decomposição da soma de quadrados da interação $\mathrm{G} \times \mathrm{E}$ e as de Plaisted \& Peterson pela decomposição da variância de $\mathrm{G} \times \mathrm{E}$.

O princípio do teste é distribuir o efeito da interação genótipos com ambientes obtida da análise de variância conjunta para cada tratamento envolvido, em função da contribuição relativa de cada um no efeito total da interação estimada.

O teste de significância da ecovalência é dado pela equação:

$$
\mathrm{F}_{(\mathrm{e}, \mathrm{r})}=(\mathrm{eco} / 2) / \mathrm{QM} \text { erro }
$$


Sendo:

e: graus de liberdade para ambientes $=2$;

r: graus de liberdade do erro $=99$;

O quociente 2 da ecovalência corresponde ao número de graus de liberdade associado à $\mathrm{SQ}_{\mathrm{GxE}}$, sendo usado para a obtenção do $\mathrm{QM}_{\mathrm{ecoi}}$.

A ecovalência em porcentagem (eco\%) foi estimada com a seguinte equação:

$$
\mathrm{eco}_{\mathrm{k}} \%=\mathrm{eco}_{\mathrm{i}} / \Sigma \mathrm{eco}_{\mathrm{ik}}
$$

sendo:

eco $\%$ : ecovalência em porcentagem do i-ésimo genótipo para o k-ésimo caráter; eco : ecovalência do i-ésimo genótipo;

$\Sigma$ eco ik: somatório da ecovalência de todos os i genótipos avaliados para o k-ésimo caráter.

A média da ecovalência em porcentagem $\left(\mathrm{M}_{\mathrm{eco} \%}\right)$ para cada genótipo é dada pela equação:

$$
\mathrm{M}_{\mathrm{eco} \%}=\Sigma \mathrm{eco}_{\mathrm{k}} \% / \mathrm{n}
$$

sendo:

$\mathrm{M}_{\mathrm{ec} \% \%}$ : média entre as eco\% dos caracteres: $\mathrm{AC}, \mathrm{VA}, \mathrm{NDM}, \mathrm{APM}, \mathrm{LVV}, \mathrm{PCS}$ e PG para cada genótipo;

¿eco $\%$ : somatório da eco\% de todos os $\mathrm{k}$ caracteres avaliados para o i-ésimo genótipo;

n: número de caracteres avaliados $(n=7)$. 
$\mathrm{O}$ desvio padrão $\left(\mathrm{S}_{\mathrm{eco} \%}\right)$ foi obtido pela raiz quadrada da variância da ecovalência em porcentagem $\left(V_{\text {eco } \%}\right)$, que foi estimada com a seguinte equação:

$$
\mathrm{V}_{\mathrm{eco} \%}=\Sigma\left(\mathrm{eco}_{\mathrm{k}} \%-\overline{\mathrm{eco} \%}\right)^{2} /(\mathrm{n}-1)
$$

sendo:

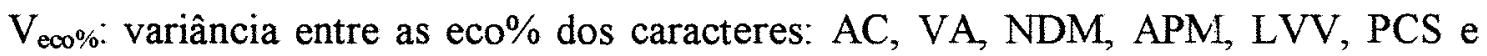
PG para cada genótipo;

$\sum \mathrm{eco}_{\mathrm{k}} \%$ : somatório da eco $\%$ de todos os $\mathrm{k}$ caracteres avaliados para o i-ésimo genótipo;

$\overline{\operatorname{eco}}^{2}{ }^{2}$ : média das eco\% de todos os $\mathrm{k}$ caracteres avaliados do i-ésimo genótipo elevado ao quadrado;

n: número de caracteres avaliados $(\mathrm{n}=7)$.

\subsubsection{Gráfico de caixa (Box Plot)}

O gráfico de caixa é um dispositivo que auxilia a análise exploratória dos dados, baseado nas estimativas das separatrizes, que são a mediana (md) e os quartis (Qi) (Iemma, 1992a e 1992b).

A mediana corresponde ao ponto que divide os dados em duas metades iguais (50\%) da distribuição e é estimada segundo a equação:

$$
\mathrm{md}=1_{\mathrm{md}}+\frac{\left(\mathrm{n} / 2-\mathrm{F}_{\text {ant }}\right)}{\mathrm{f}_{\mathrm{md}}} \cdot \mathrm{a} \mathrm{md}
$$

Sendo:

$l_{\text {md }}$ limite inferior da classe mediana;

$F_{\text {ant: }}$ frequência acumulada à direta da classe anterior à classe mediana (valor acumulado);

$\mathrm{f}_{\mathrm{md}}$ : frequência absoluta simples da classe mediana (valor do número de dados observados); 
$a_{\text {md: }}$ amplitude da classe mediana (subtração entre o valor máximo e mínimo da classe).

Os quartis representam porcentagens dos dados, sendo que o primeiro quartil $\left(\mathrm{Q}_{1}\right)$ envolve $25 \%$ dos dados e o terceiro quartil $\left(\mathrm{Q}_{3}\right)$ envolve $75 \%$, e representados pelas equações:

$$
\begin{aligned}
& \mathrm{Q}_{1}=\mathrm{l}_{\mathrm{Q}_{1}}+\frac{\left(\mathrm{n} / 4-\mathrm{F}_{\mathrm{ant}}\right)}{\mathrm{f}_{\mathrm{Q}_{1}}} \cdot \mathrm{a} \\
& \mathrm{Q}_{3}=\mathrm{l}_{\mathrm{Q}_{3}}+\frac{\left(3 \mathrm{n} / 4-\mathrm{F}_{\mathrm{ant}}\right)}{\mathrm{f}_{\mathrm{Q}_{3}}} \cdot \mathrm{a}
\end{aligned}
$$

Sendo:

$l_{\mathrm{Q}_{1}}$ e $l_{\mathrm{Q}_{3}}$ : limites inferiores das classes que contém o primeiro quartil $\left(\mathrm{Q}_{1}\right)$ e o terceiro $\left(\mathrm{Q}_{3}\right)$;

$\mathrm{F}_{\text {ant: }} \quad$ frequência acumulada da classe anterior à classe que contém o quartil que está sendo estimado;

$\mathrm{f}_{\mathrm{Q}_{1}}$ e $\mathrm{f}_{\mathrm{Q}_{3}}$ : frequências absolutas simples das classes que contém os quartis;

a: amplitude da classe do quartil que está sendo estimado.

Após as estimativas da mediana e dos quartis, o gráfico de caixa é esquematizado conforme: 
$\mathrm{X}$ valores muito discrepantes $(3 \mathrm{H})$

O valores discrepantes (entre $1,5 \mathrm{H} \mathrm{e} 3 \mathrm{H}$ )

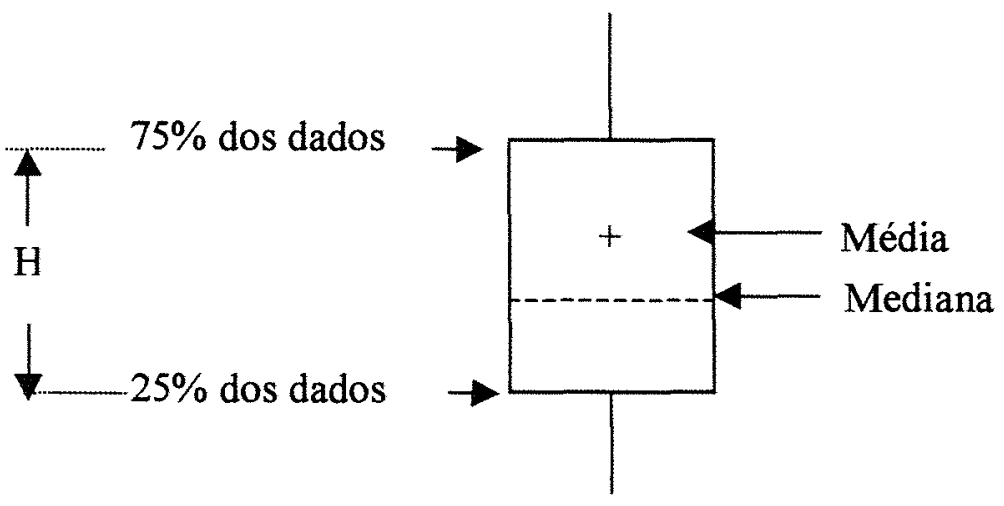

As medianas com valores menores que a média indicam a existência de assimetria positiva, enquanto que as medianas menores que a média correspondem à assimetria negativa.

Valores discrepantes são os valores que apresentam médias bem diferentes em relação à média dos demais tratamentos, mas que podem ser considerados aceitáveis. Os valores muito discrepantes são valores extremamente diferentes em relação aos demais e devem ser estudados com maior cuidado. 


\section{RESULTADOS E DISCUSSÃO}

\subsection{Considerações iniciais}

Foi possível a visualização de comportamentos muito distintos entre as progênies nos três ambientes (Tabela 12), principalmente em relação à altura da planta na maturidade (APM) e produtividade de grãos (PG). Para o caráter APM, foram obtidas médias de 58,5cm para Piracicaba-verão (ambiente agora denominado $\mathrm{PV}$ ), $51,0 \mathrm{~cm}$ para Anhembi-verão (denominado AV) e 40,2cm para Piracicaba-outono (denominado PU). Para PG, foram estimadas médias de 98,4 g/planta em PV, 75,3 g/planta em AV e um decréscimo muito acentuado para o ambiente PU com 24,4 g/planta. Essa mesma tendência ocorreu entre as testemunhas, com médias de APM de $54,1 \mathrm{~cm}$ para $\mathrm{PV}$, 47,6cm para AV e 32,3cm para PU; e, médias de PG de 95,5 g/planta para PV, 68,3 g/planta para AV e 9,68 g/planta para PU. Os demais caracteres mostraram comportamento semelhante ao observado para APM e PG entre os ambientes, ou seja, apresentaram médias superiores nos ambientes PV e AV e inferiores no ambiente PU, excetuando-se o tamanho de sementes, com comportamento relativamente semelhante nos três ambientes.

Os coeficientes de variação experimental (CV\%) são apresentados nas Tabelas 6,7 e 8. Para o caráter acamamento (AC), os CVs foram baixos nos ambientes PV e PU e relativamente alto no ambiente AV (10,86\%). Para VA, NDM, LVV e PCS os CVs foram baixos nos três ambientes. Para APM o coeficiente de variação foi baixo no ambiente AV e relativamente alto em PV e PU, com 11,5\% e 16,6\%, respectivamente. Para o caráter PG, os coeficientes de variação foram médios para os ambientes PV com 16,6\% e AV com 17,5\%; já para PU, o coeficiente foi alto $(43,0 \%)$. Esta última magnitude foi semelhante àquela encontrada por Yokomizo (1994). 
Excetuando-se PG nos ambientes PV e AV, todos os outros caracteres nos três ambientes comportaram-se semelhantemente ao observado em $F_{2}$ (Destro, 1991), em $F_{3: 2}$ (Pacova, 1992) e em $F_{5: 4}$ (Yokomizo, 1994).

O sistema de cultivo em covas, em relação ao sistema convencional em fileiras, sem dúvida causa uma elevação nas estimativas de coeficiente de variação, principalmente em caracteres mais sensíveis às variações ambientais como APM e PG (Carnielli, 1989). Os caracteres NDM, AC, VA, PCS e PG apresentaram menor sensibilidade ao sistema de cultivo empregado e, com isso, as variâncias observadas foram menos discrepantes entre si, conduzindo a um menor coeficiente de variação.

\subsection{Análise preliminar das testemunhas}

Com a finalidade de se avaliar a uniformidade ambiental dentro das repetições testou-se a existência do efeito das estratificações das repetições em conjuntos, através das análises de variância considerando apenas as testemunhas como tratamentos para cada ambiente individualmente e posteriormente para a conjunta dos três ambientes. Este procedimento de delineamento tem o objetivo de causar redução no desvio padrão residual, aumentando a precisão experimental (Pimentel-Gomes, 1991).

Nos três ambientes individualmente (Tabelas 2, 3 e 4) são observados efeitos de conjuntos (C) apenas no ambiente PU para o caráter PCS com $5 \%$ de significância e para o caráter VA com $5 \%$ de significância, no ambiente AV, de um total de 42 quadrados médios envolvendo o efeito de conjuntos, ou seja detectou-se significância em apenas $4,8 \%$ dos quadrados médios. Para a análise conjunta na Tabela 5 , observa-se dois quadrados médios significativos a 5\%, para os caracteres NDM e APM, para o efeito de conjuntos, em relação a 35 quadrados médios envolvendo esse efeito, perfazendo $5,71 \%$ de todos os quadrados médios. Por meio desta pequena porcentagem de quadrados médios apresentando significâncias, somado a ausência da presença de significância para as interações conjuntos $\mathrm{x}$ ambientes $(\mathrm{C} \mathrm{x} \mathrm{E})$, conjuntos $\mathrm{x}$ testemunhas ( $\mathrm{Te} \times \mathrm{C}$ ) e interação tripla $\mathrm{Te} \times \mathrm{C} \times \mathrm{E}$, pode-se considerar que a estratificação em conjuntos não detectou heterogeneidade dentro das repetições, tornando desnecessário o ajuste das médias dos tratamentos. 


\subsection{Anảlise de variância para os genótipos}

\subsubsection{Análise de variância para cada ambiente}

No ambiente Piracicaba-verão (PV) para a fonte de variação progênies ocorreram diferenças significativas a $1 \%$ em todos os caracteres avaliados (Tabela 6). Já para as testemunhas, dois caracteres não apresentaram diferenças significativas: acamamento (AC) e largura visual das vagens (LVV). Na comparação entre os dois grupos de genótipos formados (progênies vs. testemunhas, denominado Pro vs. Te) foram detectadas diferenças significativas para os caracteres $\mathrm{AC}$, número de dias para maturidade (NDM), altura da planta na maturidade (APM), peso de cem sementes (PCS) e LVV; no entanto, para valor agronômico (VA) e produtividade de grãos (PG) não foram observadas diferenças, ou seja, houve um comportamento similar entre os dois grupos para estes caracteres.

De acordo com a Tabela 7, no ambiente Piracicaba-outono (PU) para o efeito de progênies, todos os caracteres apresentaram diferenças significativas, a maioria a $1 \%$, e os caracteres NDM e PCS a 5\%. Para as testemunhas, apenas NDM e LVV não foram significativos. Em relação ao contraste progênie vs. testemunhas (Pro vs. Te), os caracteres AC, APM, LVV, PCS e PG foram significativos a $1 \%$, enquanto que VA foi a $5 \%$ e NDM não apresentou significância.

Para o ambiente Anhembi-verão (AV), de acordo com a Tabela 8, os caracteres apresentaram significância para as progênies a $1 \%$, excetuando-se $\mathrm{AC}$ que teve $5 \%$ de significância. Para o grupo das testemunhas, os caracteres $\mathrm{AC}, \mathrm{LVV}$ e PG não foram significativos; para o contraste Pro vs. Te, foram observadas significâncias a $5 \%$ para NDM e APM e de $1 \%$ para LVV e PCS, os demais não apresentaram significância.

Deste modo, o comportamento dos tratamentos foi semelhante ao observado em Pacova (1992) e Yokomizo (1994), ou seja, para a maioria dos caracteres ocorreram diferenças significativas entre os genótipos, tanto entre as progênies quanto 
entre as testemunhas e, também, no comportamento médio entre estes dois grupos de genótipos.

\subsubsection{Análise de variância conjunta}

$\mathrm{Na}$ Tabela 10, onde são apresentados os quadrados médios dos resíduos de cada análise individual dos caracteres avaliados, foram obtidas relações variando de 1,30 até 4,21 entre o maior e o menor resíduo, estes quocientes estão bem distantes do valor máximo 7 (Pimentel-Gomes, 1991); indicando a precisão experimental semelhante entre os ambientes, deste modo, a análise conjunta pode ser realizada, sem necessidade de ajuste nos graus de liberdade.

$\mathrm{Na}$ análise de variância conjunta para os três ambientes (Tabela 9), as progênies mostraram valores significativos a $1 \%$ para o teste $\mathrm{F}$, para todos os caracteres avaliados, indicando a existência de diferenças genéticas entre as progênies; certamente, tais diferenças são consequência da diversidade genética entre os parentais exóticos tipo alimento que participaram dos topocruzamentos.

Para o grupo das testemunhas, excetuando-se os caracteres AC e LVV que apresentaram significância de $5 \%$, os demais apresentaram níveis de $1 \%$. Isso indica existirem diferenças entre as testemunhas, o que sem dúvida é um fato real, pois as testemunhas apesar de serem do grupo de soja tipo alimento possuem características distintas.

$\mathrm{Na}$ comparação entre grupos (Pro vs. Te) somente o caráter $\mathrm{AC}$ não apresentou efeito significativo, os demais foram significativos a $1 \%$ e VA a $5 \%$. Portanto, ficou evidenciada a existência de diferenças entre os grupos formados.

Uma fonte de variação de máxima importância neste estudo é a interação genótipos $\mathrm{x}$ ambientes ( $\mathrm{G} \times \mathrm{E}$ ). De acordo com a Tabela 9, todos os caracteres apresentaram significância a $1 \%$ para a interação Progênies x Ambientes. Para melhor discriminar estes efeitos outros testes serão discutidos mais adiante.

As testemunhas apresentaram alguns caracteres (AC, NDM e LVV) que não interagiram com os ambientes; nestes caracteres, as testemunhas sofreram ação 
do ambiente, só que de maneira previsível, não causando interação $G \times E$ significativa, pois houve significância (diferença) para ambientes em todos os caracteres (Tabela 9).

De modo geral, espera-se que cultivares recomendados, em razão do grande número de testes e seleções que passaram interajam menos com os ambientes, do que as progênies que ainda estão em uma fase inicial de experimentação.

Entre as quatro testemunhas, todas soja tipo alimento com sementes grandes, 'Céu Azul' e 'IAC PL-1' são cultivares recomendados no Brasil. Já 'Tamba' e 'Nimame' são cultivares recomendados no Japão, recentemente introduzidos no Brasil. De acordo com as Tabelas 13 a 16, as duas introduções japonesas comportaram-se de maneira relativamente semelhante que os dois cultivares brasileiros, para a maioria dos caracteres. A testemunha 'Nimame' destacou-se no ambiente estressante Piracicabaoutono (Tabela 14), superando as outras três testemunhas em APM e PG.

\subsection{Contribuição de cada fonte de variação na diversidade total dos dados}

Considerando-se apenas as somas de quadrados das progênies $\mathrm{e}$ estimou-se a contribuição percentual de cada fonte de variação na diversidade total, excetuando-se as fontes testemunhas e progênies vs. testemunhas (Tabela 11). Este procedimento permite estimar de forma simples o quanto cada fonte de variação contribui para o total da variação existente nos experimentos.

Na Tabela 11, observa-se que os caracteres: AC, VA, NDM e PG apresentaram o ambiente como a fonte de variação mais importante; isto pode ser explicado pelas diferentes condições climáticas, principalmente fotoperíodo, entre os cultivos de verão e outono em Piracicaba (PV e PU); além disso, diferenças nas propriedades fisicas e químicas do solo entre os ambientes Piracicaba (terra roxa estruturada) e Anhembi (solo tipo aluvial distrófico) certamente também contribuíram para a significância dos efeitos dos ambientes. $\mathrm{O}$ ambiente Piracicaba-verão permitiu um maior crescimento das plantas, enquanto nos dois ambientes estressantes (PU e AV) as plantas cresceram menos e, com isso, também acamaram menos. A produtividade diminuiu muito no ambiente Piracicaba-outono e alcançou valor intermediário no ambiente Anhembi-verão, cujo solo é muito arenoso e de menor fertilidade. O ciclo 
medido pelo tempo para a planta atingir a maturidade, foi afetado pelas condições de fotoperíodo de outono em contraste com o de verão. Os caracteres AC e PG no ambiente PV comportaram-se semelhantemente em Yokomizo (1994). Para VA e NDM houve predominância de efeitos genéticos; para APM, LVV e PCS, a parte genética contribuiu com maior intensidade para as variações entre progênies, que apresentaram valores de contribuição relativa maiores que $53 \%$, ou seja, mais da metade de toda a variação observada tem natureza genética. Estes valores de contribuição são menores do que o mínimo de $70 \%$ obtido em $\mathrm{F}_{5: 4}$ (Yokomizo, 1994). Entretanto a contribuição do efeito de ambientes para o caráter APM não deve ser desprezada, pois é o segundo mais importante em termos de contribuição relativa. A interação $\mathrm{G} \times \mathrm{E}$ manifestou-se com maior intensidade para os caracteres NDM e PCS, com 22,73\% e 24,98\%, respectivamente; portanto diferiu do obtido em $\mathrm{F}_{5: 4}$ (Yokomizo, 1994), geração em que a maior interação $G \times E$ foi observada em $A C$ e PG. Os menores valores de $\mathrm{G} \times \mathrm{E}$ ocorreram para APM e PG, com 7,88\% e 4,44\%, respectivamente e, obteve-se grande influência dos ambientes alterando os caracteres PG e VA, 82,97\% e 67,05\% respectivamente, representando mais da metade da variação total, a herança quantitativa de PG e VA certamente é a responsável pelos efeitos pronunciados dos ambientes.

\subsection{Médias e desvios padrões dos genótipos}

$\mathrm{Na}$ discussão, as progênies serão apresentadas na forma de números, cuja identificação dos parentais envolvidos encontra-se na Tabela 1.

Para os desvios padrões que representam a variabilidade existente dentro de progênies, $o$ interessante nesta fase (geração $F_{9: 4}$ ) seria a estimativa de valores próximos de zero; porém, como as plantas existentes dentro das parcelas, em alguns casos, podem ter tido origem de progênies diferentes, mas pertencentes ao mesmo topocruzamento, algumas estimativas altas de desvio padrão podem ser esperadas, representando com isso a variabilidade genética disponível quando seus valores ultrapassarem a média dos desvios padrões obtidos dentro das testemunhas (variabilidade ambiental). 


\subsubsection{Largura visual das vagens}

A largura visual das vagens (LVV) é um caráter que visa avaliar o tamanho de sementes de um modo mais rápido e prático; para tanto, adotou-se uma escala apresentada no Apêndice 1, no qual as notas são comparadas com a largura em $\mathrm{mm}$ das vagens; a metodologia e sua praticidade podem ser melhor entendidas em Yokomizo (1994) Yokomizo \& Vello (1998).

De acordo com a Tabela 13, para as médias das progênies em Piracicaba-verão (PV) os melhores resultados foram obtidos em seis $(25 \%$ de 24$)$ progênies $\left(n^{\circ} 2,7,14,15,16\right.$ e 21) com médias iguais ou maiores que 3,0, a qual pode ser considerada uma nota adequada para a obtenção de soja tipo alimento com sementes grandes. Ao se considerar as médias das testemunhas, todas elas cultivares de soja tipo alimento, pode-se aceitar médias de LVV em torno de 2,8; neste caso, as progênies $8 \mathrm{e}$ 11 também seriam incluídas entre as selecionadas. Os desvios padrões para os dados transformados (Tabela 13) foram maiores para o ambiente PV nas progênies $2,3,4,6,9$, 13, 14 e 20, com valores acima de 0,20; estas medidas de variabilidade são maiores que a média dos desvios padrões das testemunhas $(0,0517)$ e de intensidade relativamente menor aos limites observados no ambiente PU (Tabela 14).

Nas condições estressante de Piracicaba-outono (PU) as maiores médias de LVV foram observadas nas progênies 5, 8, 14, 15, 20 e 21; neste ambiente, a média entre as testemunhas aumentou para próximo de 3,0 ; considerando este valor como uma referência mínima para seleção, somente as progênies já citadas seriam selecionadas, pois as demais apresentaram médias menores que 3,0. Efeitos de gerações e escala subjetiva para avaliar LVV, podem explicar as diferenças em relação às observações feitas em $F_{3: 2}$ (Pacova, 1992) e em $F_{5: 4}$ (Yokomizo, 1994). Os desvios padrões baseados em dados transformados para o caráter LVV foram maiores para as progênies $1,4,10,11,12,13,14,15,18,23$ e 24, com valores acima de 0,0495; tais valores são bem superiores à da média $(0,0385)$ dos desvios das testemunhas, ou seja, estas progênies devem conter variabilidade genética remanescente.

Em Anhembi-verão (AV), as vagens apresentaram tendência de serem mais estreitas (Tabela 15). Considerando-se a média das testemunhas ( $\mathrm{LVV}=2,7)$ como 
referência de seleção, as progênies destaques seriam as de $\mathrm{n}^{\circ} 1,5,7,11,14,15,16$ e 21 , com médias entre 2,73 e 2,98. Quase todos os genótipos testados apresentaram baixa variabilidade dentro de progênies, de maneira que apenas as progênies $7,8,11,12,16 \mathrm{e}$ 19 , superaram a média de desvios padrões das testemunhas $(0,0556)$; isto vem indicar que estas progênies ainda possuem variabilidade genética disponível para seleção no sentido de maior LVV.

Nos três ambientes individualmente não foram observadas médias para LVV abaixo de 2,0, que poderiam ser consideradas inadequadas para este tipo de soja. Porém, as menores médias de LVV nem sempre foram associadas com as menores médias de PCS, provavelmente devido a falhas na granação, fato este que deve ser evitado como foi citado em Yokomizo (1994) e Yokomizo \& Vello (1998). Comparativamente, as progênies 14,15 e 21 apresentaram os melhores desempenhos individuais em todos os ambientes.

$\mathrm{Na}$ Tabela 16, para os três ambientes em conjunto, tem-se como destaques as progênies $2,7,14,15,16$ e 21 com médias de LVV acima de 2,9. Apesar de não haver progênie com média inferior a 2,0 , deve-se considerar como referência a média das testemunhas $(2,8)$ e, neste caso, apenas mais duas progênies $(5$ e 8$)$ se somariam aos destaques anteriores. Considerando-se a média entre os desvios padrões das testemunhas como uma medida da variabilidade ambiental, observa-se que as progênies $1,2,3,5,7,8,9,10,11,12,13,16,19,20$ e 24 foram aquelas com maior variabilidade genética para $L V V$.

A maioria das progênies com médias de LVV superiores a 3,0 nesta geração $F_{9: 4}$ também foram em $F_{5: 4}$ (Yokomizo, 1994), exceto as progênies 2, 5, 20 e 21, as quais com o processo de endogamia e seleção gradativa tiveram sua LVV aumentada.

As seguintes progênies apresentaram maior destaque para LVV, tanto nos três ambientes individualmente quanto em conjunto, acompanhadas de seus desempenhos médios:

№ 14, USP 98-06019, obtida de Japão 1 x Doko, com LVV=3,10;

№ 15, USP 98-06021, obtida de Japão 2 x Doko, com LVV=3,03;

№ 21, USP 98-06028, obtida de FC 31-665 x Doko, com LVV=3,12. 


\subsubsection{Valor agronômico}

O valor agronômico (VA) é uma nota que visa reunir os atributos favoráveis existentes na planta de soja, ou seja, a altura adequada da planta, a produtividade de grãos, o acamamento, a sanidade tanto para pragas como para doenças, o tamanho das sementes, a presença ou não de haste verde e de retenção foliar. Esta nota é aplicada visualmente reunindo-se todos estes fatores de modo subjetivo, correspondendo a um registro do desempenho geral da planta observado no campo pelo pesquisador.

As discussões seguintes relativas às médias feitas com base nos dados originais (sem transformação) e os desvios padrões com base nos dados transformados de valor agronômico.

Pela Tabela 13, nas condições favoráveis de Piracicaba-verão (PV), as melhores médias foram obtidas pelas progênies $4,5,10,14,20$ e 22, com valores de VA entre 2,2 e 2,8 . Tais médias podem ser consideradas boas para este tipo de material, por se tratar de soja alimento. Existem sete progênies $(3,7,11,16,17,18$ e 19) com médias inferiores a 2,0 , que devem ser observadas com ressalvas para os demais caracteres, apesar de apresentarem desempenho para este caráter próximo ao da média das testemunhas. Discutindo-se os desvios padrões baseados nas médias transformadas temse que os maiores desvios foram observados para as progênies $2,3,4,7,10,14$ e 15, com valores acima de 0,0473 , ou seja, acima da média estimada de 0,0454 entre os desvios das testemunhas; portanto, as progennies citadas anteriormente seriam aquelas com variabilidade genética para o caráter.

Em Piracicaba-outono (PU, Tabela 14) as médias de VA diminuíram muito, concentrando-se em torno de 1,0 a 1,8 , ou seja, numa faixa estreita de notas baixas. Seis progênies $(6,13,14,17,18$ e 24$)$ apresentaram médias entre 1,6 e 1,8 , que foram superiores à média das testemunhas e próximo ao obtido para as progênies descendentes de 'Doko' em F $F_{2}$ (Destro, 1991) e pouco menor ao obtido em F $F_{3: 2}$ (Pacova, 1992). Deve-se lembrar que estas diferenças podem ter ocorrido em razão do VA ser uma escala de notas subjetivas. As condições estressantes (principalmente fotoperíodo) de outono causaram uma diminuição nos desvios padrões das testemunhas, cuja média 
foi 0,0452 ; considerando este valor como medida da variabilidade ambiental, tem-se um grande número de progênies com variabilidade genética disponível, um total de 12 (progênies: $1,2,4,8,9,10,11,12,17,18,20$ e 22).

Em Anhembi-verão (AV, Tabela 15) sete progênies $(1,8,9,13,17,19$ e 22) apresentaram médias de VA entre 2,2 e 2,8 . Três progênies $(2,11$ e 16) apresentaram médias abaixo de 1,7 , indicando que estes materiais podem ser inadequados como soja tipo alimento. As condições ambientais fornecidas em Anhembiverão produziram um comportamento intermediário nos desvios padrões para as progênies relativamente aos ambientes $\mathrm{PV}$ e $\mathrm{PU}$, sendo que 16 progênies apresentaram valores acima da média dos desvios padrões das testemunhas $(0,0413)$; estas progênies podem ser consideradas como possuidoras de variabilidade genética remanescente.

Observando-se as melhores progênies em cada ambiente, é encontrado baixa coincidência entre elas; entre PV e PU existe como destaque comum apenas a progênies 14; entre PV e AV há coincidência de destaque apenas da progênie 22; entre $\mathrm{PU}$ e AV, coincidem como destaques as progênies 13 e 17, indicando possivelmente que as progênies assumiram um comportamento mais aproximado de especificidade para cada ambiente em relação a VA.

$\mathrm{Na}$ Tabela 16 tem-se o comportamento das médias das progênies envolvendo os três ambientes em conjunto. As melhores progênies foram as de $n^{\circ} 6,9$, $13,14,17,18,19,22$ e 24, com médias superiores a 1,9; tais médias podem ser consideradas adequadas quando comparadas com a média das testemunhas $(1,8)$; caso seja utilizada esta média como um referencial do mínimo aceitável para VA, tem-se mais seis progênies promissoras $(1,3,8,10,12$, e 20$)$. Ao se analisar os três ambientes em conjunto ocorreu um aumento nas estimativas de desvio padrão de todas as progênies, com isso, a média dos desvios padrões das testemunhas foi $0,1604 \mathrm{e}$ as progênies $1,2,5,8,9,10,12,15,20,21$ e 22 foram as que apresentaram valores maiores que esta média, podendo ser consideradas como as que apresentam variabilidade genética.

Excetuando-se a progênie $\mathrm{n}^{\mathrm{o}} 14$, cuja média foi inferior, os demais destaques em $F_{9: 4}$ também apresentaram médias altas em $F_{5: 4}$ (Yokomizo, 1994). 


\subsubsection{Acamamento}

A nota de acamamento (AC) é aplicada subjetivamente numa planta possibilitando ter-se uma idéia da inclinação da haste principal da planta em relação ao solo no campo. Uma planta ideal deve ser a mais ereta possível, formando ângulo de $90^{\circ}$ com o solo, avaliada pela nota 1. Uma planta com acamamento máximo (nota 5 ) tende a se prostrar no solo e, com isso, permitir o apodrecimento das vagens que ficam em maior contato com a umidade existente. Portanto, para $\mathrm{AC}$ o ideal são médias menores, ou seja, quanto menor a média mais ereta será a planta. Além de um componente genético relacionado principalmente ao diâmetro e à resistência da haste principal, o AC também recebe influência ambiental de intensidade variável com as condições tanto de semeadura (ou de plantio com mudas), do tipo de solo, da pluviosidade; o AC também é dependente da altura da planta.

As discussões para este caráter serão com base nas médias dos dados originais (sem transformação) e dos desvios padrões com os dados transformados.

Nas condições de verão em Piracicaba (PV), devido ao maior crescimento vegetativo das plantas, as mesmas tiveram tendências de acamarem mais; com isso, as notas médias de AC foram elevadas, sendo as mais adequadas observadas para as progênies $5,10,14$ e 20 com valores de $\mathrm{AC}$ entre 2,4 e 2,8. Os maiores desvios padrões foram observados para 12 progênies, cujas estimativas foram maiores que 0,0996 . Estas progênies devem possuir variabilidade genética além da ambiental obtida da média $(0,0949)$ dos desvios das testemunhas.

De acordo com a Tabela 14, em Piracicaba-outono (PU) sete progênies $(2,4,514,15,16$ e 20) apresentaram niveis mínimos de $\mathrm{AC}$ com valores entre 1,3 e 2,0, relativamente à média das testemunhas $(2,2)$. Nas condições PU ocorreu uma aumento grande dos desvios padrões das testemunhas (média de 0,1820 ) em relação ao ambiente $\mathrm{PV}$; com isso, apenas as progênies $2,12,14,15,20$ e 21 , com estimativas de desvios acima de 0,70 , podem ser consideradas como as que possuem variabilidade genética além da ambiental expressada pelas testemunhas.

Em Anhembi-verão (AV, Tabela 15), provavelmente devido à menor altura da planta causada pelas limitações de fertilidade do solo foram obtidas médias 
menores de $\mathrm{AC}$, em relação aos outros dois ambientes. Em $\mathrm{AV}$, as progênies mais promissoras foram as de $\mathrm{n}^{\circ} 5,7,15,19$ e 21 , com médias de $\mathrm{AC}$ entre 1,1 e 1,3; porém, as progênies que apresentaram médias inferiores à média das testemunhas $(2,1)$ ainda podem ser consideradas como promissoras; neste caso, mais 13 progênies poderiam ser incluídas entre as promissoras. $\mathrm{O}$ ambiente $\mathrm{AV}$ foi o que causou maior variabilidade nas testemunhas, devido às condições específicas deste local, com a média dos desvios padrões das testemunhas igual a 0,1937 ; a maioria das progênies não acompanharam este aumento, de maneira que somente as progênies $3,9,13$ e 23 apresentaram valores acima de 0,2284 e, com isso, são as únicas que podem ser consideradas possuidoras de variabilidade genética remanescente.

Observando-se a Tabela 16, para o caráter AC e os três ambientes em conjunto, apenas duas progênies ( 5 e 20 ) apresentaram médias inferiores a 2,0 ; dez progênies apresentaram médias entre 2,0 e 3,0 e devem ser avaliadas cuidadosamente. As médias foram elevadas principalmente devido à contribuição do ambiente $P V$, cujo acamamento apresentou médias muito altas. A combinação dos três ambientes causou uma aumento nos desvios padrões, porém com maior intensidade nas testemunhas (média entre desvios padrões igual a 0,3145); com isso as progênies $7,11,15,16,19$, $21,22,23$ e 24 , com valores acima de 0,3183 , podem ser consideradas como as que possuem variabilidade genética disponível.

$\mathrm{O}$ ambiente $\mathrm{PV}$ proporcionou médias de acamamento superiores àquelas observadas em $F_{5: 4}$ (Yokomizo, 1994), enquanto que o ambiente $\mathrm{AV}$ teve melhor desempenho entre os ambientes testados e também comparativamente com $o$ obtido em $\mathrm{F}_{5: 4}$ (Yokomizo, 1994).

Valores acima de 3,0 para $\mathrm{AC}$ em todos os ambientes e na conjunta podem ser considerados preocupantes e devem ser analisados cuidadosamente, levandose em consideração os demais caracteres. 


\subsubsection{Número de dias para a maturidade}

O número de dias para a maturidade (NDM) é uma característica que deve ser levada em consideração nos programas de melhoramento, pois o escalonamento dos plantios, e das colheitas necessitam da existência de genótipos com ciclos diferentes. Além disso, na agricultura moderna é crescente o interesse por genótipos precoces que possibilitem mais que um cultivo por ano, principalmente em associação com sucessão e rotação de culturas. No caso da soja alimento, o NDM tem importância para se obter colheitas em menor tempo possivel.

As médias estimadas para NDM variaram de 105 a 141 dias (Tabela 13), ou seja existem progênies com ciclos variáveis de precoce a semi-tardio; as progênies mais precoces $(2,5,7,10,11$ e 16) apresentaram médias inferiores a 110 dias nas condições de Piracicaba-verão (PV). As progênies com maior variabilidade foram as de $\mathrm{n}^{\mathrm{o}} 1,6,10,15,18,19,20$ e 23, com valores de desvio padrão maiores que 2,1; é possível a seleção de alguns genótipos segregantes dentro de cada uma destas progênies, pois a média dos desvios padrões das testemunhas foi inferior a 2,1.

De acordo com a Tabela 14, as condições estressantes do ambiente Piracicaba-outono (PU), provocaram aceleração do ciclo (menor NDM) das plantas em relação ao obtido no ambiente PV. Em alguns casos, o decréscimo do ciclo alcançou 30 dias, como por exemplo nas progênies $8,17,18$ e 19. Consequentemente, 13 progênies (54\% de 24$)$ apresentaram ciclos médios inferiores a 110 dias. No ambiente PU a variação observada foi de 100 a 120 dias, existindo duas exceções que aumentaram o ciclo em torno de 10 dias, correspondentes às progênies 5 e 10 (Tabela 14). As médias observadas de APM foram superiores às obtidas em $F_{2}$ (Destro, 1991) com 97 dias e em $F_{3: 2}$ (Pacova, 1992) com 95 dias, pois todos os genótipos apresentaram ciclos superiores a 100 dias em $\mathrm{F}_{9: 4}$. Desvios padrões muito altos (maiores que 5,0) foram observados nas progênies 2, 10 e 11; portanto, estas foram as que apresentaram maior variação dentro, possuindo variabilidade genética disponivel pois superaram a média de 4,3 observada dos desvios padrões das testemunhas.

$\mathrm{O}$ ambiente Anhembi-verão (AV, Tabela 15), apresentou médias entre 112 dias e 146 dias, correspondendo a ciclos mais tardios que o ambiente $\mathrm{PV}$, com 
aumentos no ciclo de até 11 dias; maiores aumentos de ciclo foram observados nas progênies $1,5,10,16,19,23$ e 24 ; somente a progênie 12 apresentou diminuição significativa quando comparada com o ambiente PV; outra constatação é que nenhuma progênie apresentou ciclo igual ou inferior a 110 dias em AV (Tabela 15). Quanto à variabilidade, os maiores valores foram observados nas progênies $3,6,17,18,23$ e 24 com desvios padrões acima de 4,3 e maiores que a média dos desvios das testemunhas $(4,2)$. Maiores variações foram observadas nos ambientes PU e AV, relativamente a PV.

Para os ambientes em conjunto (Tabela 16) obteve-se ciclos de 108 dias até 132 dias, existindo apenas três progênies com médias de NDM inferiores a 110 dias; a maioria das progênies ( 14 ou $58 \%$ de 24 ) tiveram suas médias próximas a 120 dias. Este resultado é interessante, pois corresponde a uma predominância de progênies com ciclo precoce a semi-precoce, ciclos estes muito demandados na agricultura atual, com a sucessão de dois cultivos por ano na mesma área. A análise do desvio padrão com os três ambientes em conjunto mostra um aumento das diferenças entre as estimativas, devido a grandes alterações entre os ambientes; com isso, as maiores variabilidades foram observadas nas progênies $1,3,6,8,17,18,19,23$ e 34, com estimativas de desvio padrão acima de 10,0 dias.

Observando-se as médias obtidas, pode-se notar que em geral as progênies foram mais precoces que a média de 149 dias obtida em $\mathrm{F}_{5: 4}$ por Yokomizo (1994); certamente, isso ocorreu em consequência da seleção favorável às progênies mais precoces de geração para geração.

\subsubsection{Altura da planta na maturidade}

Em lavouras comerciais de soja, com colheita mecanizada, o referencial mínimo altura da planta na maturidade (APM) é de $60 \mathrm{~cm}$ (São Paulo, 1990). Quando cultivada em covas, como na presente pesquisa, a planta de soja tende a crescer menos e ramificar mais (Ritchie et al., 1985); assim em termos práticos, pode-se diminuir, talvez para $50 \mathrm{~cm}$, o valor mínimo de APM para cultivos em covas de plantas individuais. Apesar dos genótipos testados serem soja tipo alimento, em que a APM não representa um empecilho maior na colheita, por não ser realizada mecanicamente, 
materiais mais altos apresentam uma melhor aparência, e este fato é de suma importância para a soja tipo alimento, principalmente quando a comercialização for realizada na forma de maços com as vagens imaturas ainda presas na haste principal e nas ramificações da planta, forma esta de comercialização tradicional no Japão. Além disso, deve-se considerar também a possibilidade de correlação positiva entre NDM e PG, como será discutido em itens seguintes.

A Tabela 13 indica a existência de genótipos promissores sendo pesquisados, com APM acima de $60 \mathrm{~cm}$, totalizando 12 progênies ( $50 \%$ de 24 ) no ambiente favorável Piracicaba-verão (PV). Entre as progênies mais baixas restantes quatro apresentaram médias entre 50 e $60 \mathrm{~cm}$ e oito progênies tiveram médias de APM abaixo de $50 \mathrm{~cm}$. Nas condições de PV, maiores valores de variabilidade genética foram observados nas progênies $1,6,8,12,13,17,18,19,21$ e 22 , com desvios padrões maiores que 5,4 , superando a média de $4,6 \mathrm{~cm}$ dos desvios das testemunhas.

Em relação ao ambiente Piracicaba-outono (PU, Tabela 14), a alta sensibilidade dos genótipos ao fotoperiodo mais curto causou uma acentuada queda nas médias de APM; consequentemente, apenas cinco progênies (3, 13, 6, 11 e 18) apresentaram médias acima de $50 \mathrm{~cm}$. Ao se comparar as médias dos ambientes PU e PV, observa-se que a APM diminuiu cerca de $20 \mathrm{~cm}$; as maiores diminuições aconteceram nas progênies $1,8,19$, apresentando médias no ambiente PU em torno de $30 \mathrm{~cm}$ menores que no cultivo em PV. Destaque especial ocorreu para as progênies 3 e 11, as quais mantiveram a APM relativamente constante nos ambientes PV (Tabela 13) e PU (Tabela 14), fato este indicativo de tolerância ao fotoperiodo (Hartwig \& Kiihl, 1979; Kiihl \& Garcia, 1989; Hinson, 1989). Incluindo-se a APM observada no ambiente AV (Tabela 15) tem-se as seguintes médias em $\mathrm{cm}$ :

- $\mathrm{N}^{\mathrm{Q}}$ 3, USP 98-06007, (KS $\left.473 \times \mathrm{SJ}_{2} \mathrm{~F}_{7}\right)$ x Doko: 73,5 (PV); 72,2 (PU) e 73,8 (AV);

- No 11, USP 98-06016, Late Giant x Doko: 52,9 (PV); 51,6 (PU) e 38,3 (AV).

A progênie 3 é vantajosa sobre a progênie 11, porque manteve a mesma APM também em AV, demonstrando possuir tolerância ao complexo de acidez e à fertilidade reduzida do solo arenoso de $\mathrm{AV}$. As progênies 3 e 11 ainda apresentam médias menores do que as obtidas em $F_{3: 2}$ por Pacova (1992) e maiores do que em $F_{2}$ 
(Destro, 1991). A variabilidade no outono (PU) apresentou uma tendência de diminuição, sendo que duas progênies (10 e 11) apresentaram desvios padrões acima de 20,0. Também apresentaram alta variabilidade as progênies $2,6,13,16,21$ e 23 com valores maiores que a média entre os desvios das testemunhas $(3,7)$.

No ambiente Anhembi-verão (AV, Tabela 15) observou-se comportamento intermediário entre os dois de Piracicaba (PV e PU), com sete progênies $(3,6,9,13,17$, 18 e 19) apresentando médias acima de $60 \mathrm{~cm}$, quatro progênies com médias entre $50 \mathrm{~cm}$ e $60 \mathrm{~cm}$ e 12 progênies com APM abaixo de $50 \mathrm{~cm}$. O ambiente AV causou uma diminuição na média em torno de $10 \mathrm{~cm}$ relativamente ao ambiente $\mathrm{PV}$, porém foram obtidas cinco progênies $(3,6,9,18$ e 23) com médias de APM semelhantes à observada em PV. Para os desvios padrões não foram observados valores que possam ser considerados altos, ou seja, cada progênie mostrou APM relativamente uniforme em PV; com isso, apenas as progênies 8 e 23 apresentaram desvios padrões maiores que 4,0 e nenhuma superou a média dos desvios das testemunhas (7,5); assim, pelo menos em AV, pode-se considerar que a variabilidade observada dentro de progênies para APM é de natureza ambiental.

Comparando-se os três ambientes (Tabelas 13 a 15), existiram progênies que mantiveram médias de APM promissoras mesmo nas condições adversas de outono (PU) e de solo de baixa fertilidade (AV). Excetuando-se a progênie 11 que não atingiu $50 \mathrm{~cm}$ de APM em Anhembi-verão, as demais progênies citadas para o ambiente PU, confirmaram seus desempenhos adequados nos outros dois ambientes.

Quando se considera os três ambientes juntos (Tabela 16) observa-se que 13 progênies (54\% de 24) apresentaram médias superiores ao referencial mínimo de $50 \mathrm{~cm}$; as maiores médias foram apresentadas pela progênie $3(73,2 \mathrm{~cm})$; progênie $6(67,8 \mathrm{~cm}) \mathrm{e}$ progênie $13(68,3 \mathrm{~cm})$. Devido ao acentuado contraste entre os ambientes, houve um aumento sensível na variabilidade entre plantas dentro de progênies, conforme evidenciado pelos seus valores elevados de desvios padrões. Os maiores níveis de variabilidade foram observados nas progênies $1,6,8,10,17,19$ e 23, com valores de APM acima da média dos desvios das testemunhas $(11,3 \mathrm{~cm})$, valor este que pode ser considerado como representativo da variabilidade ambiental existente. Os valores 
relativos de médias e desvios padrões das progênies para APM foram semelhantes àqueles já discutidos para NDM.

Considerando-se os ambientes PV e AV, pode-se observar que as progênies F $_{9: 4}$ com plantas mais altas apresentaram médias de APM semelhantes às obtidas por Yokomizo (1994) na geração $F_{5: 4}$.

\subsubsection{Produtividade de grãos}

A produtividade de grãos (PG) é uma característica importante para os programas de melhoramento de soja tipo grão, pois sempre se procura a obtenção de genótipos mais produtivos em relação aos já existentes. No caso da soja tipo hortaliça (Edamame) a PG também é importante, pois o produto comercial são os maços de plantas com vagens imaturas ou as próprias vagens imaturas armazenadas em sacos plásticos fechados a vácuo e congelados (Konovsky \& Lumpkim $^{1}$ ); sem dúvidas, a PG também é importante para as demais categorias de soja alimento, incluindo-se a soja tipo "Kuromame" (grãos pretos, grandes e maduros, usados na preparação de doces especiais) e a soja tipo salada (grãos claros ou variegados, grandes e maduros).

A Tabela 13 demonstra que no ambiente favorável de Piracicaba-verão (PV) foram obtidas apenas duas progênies com médias de PG abaixo de $50 \mathrm{~g} /$ planta, considerado como o referencial mínimo aceitável, por representar cerca de 250 sementes. As melhores médias de PG atingiram mais de $100 \mathrm{~g} /$ planta, sendo que 12 progênies $(50 \%$ de 24$)$ apresentaram valores acima deste limite. As quatro melhores progênies foram: $12,13,22$ e 24 ; tais progênies têm adaptação ao ambiente PV, caracterizado principalmente por um solo de alta fertilidade e fotoperíodo ideal do cultivo de verão. A variabilidade para $\mathrm{PG}$ pode ser considerada alta, sendo que as progênies $3,4,13,14$ e 20 apresentaram desvios padrões maiores que a média dos desvios padrões das testemunhas $(16,71 \mathrm{~g} /$ planta), ou seja, certamente existe variabilidade genética entre as plantas das progênies antes mencionadas.

\footnotetext{
${ }^{1}$ KONOVSKY, J. \& LUMPKIM, T.A. Edamame production and use: a global perspective. In: NA INTERNATIONAL CONFERENCE SOYBEAN PROCESSING AND UTILIZATION. Gongzhuling, Jilin Province, China, 1990. 12p.
} 
$\mathrm{Na}$ Tabela 14, nas condições de Piracicaba-outono (PU) pode-se observar que ocorreu uma queda muito acentuada na PG; somente duas progênies ( 9 e 24) tiveram suas médias próximas de $50 \mathrm{~g} /$ planta $\mathrm{e}$, portanto, apresentaram tolerância às condições muito estressantes do ambiente PU, dadas principalmente pelo fotoperíodo mais curto da semeadura atrasada (março) e do cultivo de outono; as demais progênies produziram abaixo de $50 \mathrm{~g} /$ planta. Ocorreram grandes diminuições de $\mathrm{PG}$ quando se compararam as médias obtidas em PU e em PV, atingindo-se até $124 \mathrm{~g}$ a menos em PU para a progênie 13; também ocorreram diminuições relativamente menores, de cerca de $30 \mathrm{~g}$ para as progênies 2 e 11 . Este fato indica que as progênies sofreram uma grande influência das condições ambientais, principalmente das variações do fotoperíodo e, também da temperatura e umidade do solo; metade das progênies avaliadas tiveram desempenho inferior à média (26g/planta) obtida $\mathrm{em} \mathrm{F}_{2}$ por Destro (1991), enquanto que apenas seis progênies foram melhores que a média (34g/planta) em $F_{3: 2}$ (Pacova, 1992). As condições de outono causaram uma maior uniformidade na PG das plantas de cada

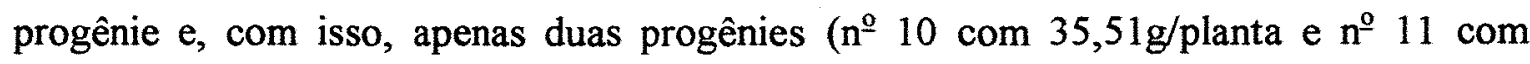
$30,23 \mathrm{~g} /$ planta) apresentaram desvios padrões acima de $10,0 \mathrm{~g} /$ planta. As progênies 2, 6, $14,17,18$ e 19, também mostraram desvios superiores à média dos desvios padrões das testemunhas $(3,8 \mathrm{~g} /$ planta $)$, ou seja, têm variabilidade genética remanescente.

Pela Tabela 15, em Anhembi-verão (AV), somente cinco progênies não atingiram médias superiores a $50 \mathrm{~g} /$ planta e quatro progênies $(9,12,13$ e 22) alcançaram médias de PG superiores a 100g/planta. Apesar das avaliações terem sido feitas na mesma época que nos ambientes PV, e AV, a PG tendeu a ser menor em AV, citando-se como exemplos as progênies: $n^{0} 24$, com diminuição de $70 \mathrm{~g} /$ planta; $\mathrm{n}^{\mathrm{o}} 13$,

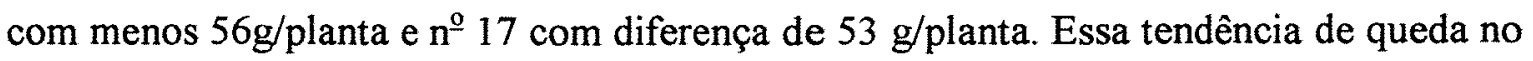
desempenho geral das progênies em $\mathrm{AV}$ deveu-se principalmente ao tipo de solo de baixa fertilidade encontrado em Anhembi. Semelhantemente ao ambiente PV da Tabela 13, ocorreram grandes variações de PG entre as plantas das progênies; com isso 13 progênies ( $54 \%$ de 24$)$ apresentaram valores de desvio padrão acima de $11,5 \mathrm{~g} /$ planta que é a média dos desvios das testemunhas; os maiores desvios ocorreram na progênies 3 com $23,4 \mathrm{~g} /$ planta e na progênie $19 \mathrm{com} 39,2 \mathrm{~g} /$ planta (Tabela 15). 
Contrariando a tendência de queda de $\mathrm{PG}$ no ambiente $\mathrm{AV}$, duas progênies ( 2 e 5) foram semelhantes em PG nos dois ambientes (AV e PV) e três progênies $(9,15$ e 22$)$ foram superiores em $A V$, relativamente aos outros dois ambientes. Todas as cinco progênies, mas principalmente as progênies 9,15 e 22 devem possuir genes para tolerância às condições limitantes, principalmente em relação à baixa fertilidade do solo de AV.

Selecionando-se as progênies superiores em PG em cada ambiente, pode-se observar que as progênies 9 e 12 mantiveram médias relativamente altas nos três ambientes e, portanto, têm adaptação ampla.

Em relação à média dos três ambientes (Tabela 16) a maioria dos genótipos foram promissores, excetuando-se as progênies $2,7,11,15$ e 16 , cujas médias foram menores que $50 \mathrm{~g} /$ planta. Os demais 19 genótipos avaliados apresentaram médias promissoras, destacando-se as progênies $3,9,12,13,22$ e 24, com médias de PG igual ou acima de $80 \mathrm{~g} /$ planta; as médias retiradas das Tabelas $13,14,15$ e 16 ilustram a PG (g/planta) das seis progênies mais destacadas:

- № 3, USP 98-06007, (KS $473 \times \mathrm{SJ}_{2} \mathrm{~F}_{7}$ ) x Doko, 122,2 (PV), 38,6 (PU), 79,3 (AV) e 80,0 (Geral).

- № 9, USP 98-06014, Late Giant x Doko, 103,1 (PV), 50,8 (PU), 123,3 (AV) e 92,4 (Geral).

- $\mathrm{N}^{\mathrm{o}}$ 12, USP 98-06017, Late Giant x Doko, 132,2 (PV), 37,0 (PU), 110,2 (AV) e 93,1 (Geral).

- № 13, USP 98-06018, Late Giant x Doko, 161,6 (PV), 37,1 (PU), 105,4 (AV) e 101,4 (Geral).

- № 22, USP 98-06029, Majos x Doko, 134,1 (PV), 36,0 (PU), 135,9 (AV) e 102,0 (Geral).

- № 24, USP 98-06032, Tadacha x Doko, 151,2 (PV), 45,1 (PU), 80,8 (AV) e 92,4 (Geral).

Comparada com as análises de ambientes individuais, na análise conjunta dos três ambientes ocorreu um aumento na variabilidade entre plantas dentro de progênies e de testemunhas, pois foram reunidos valores relativamente altos de desvios 
padrões obtidos nas condições favoráveis de verão ( $\mathrm{PV}$ e AV) com as baixas médias de PG obtidas no outono (PU); na análise conjunta dos três ambientes, a média dos desvios das testemunhas foi igual a 40,6; com isso, apresentaram variabilidade genética as progênies $8,12,13,17,20,21,22$ e 24 .

Além dos relatos anteriores de adaptação ótima restrita de algumas progênies a um ambiente em particular, devem ser destacadas também as progênies $13 \mathrm{e}$ 22, as quais apresentaram as maiores médias de PG para os três ambientes em conjunto; essas duas progênies têm como limitação terem sido medianamente sensíveis às condições estressantes (principalmente fotoperíodo mais curto) do cultivo de outono (PU). Já as progênies 9 e 24 mostraram maior tolerância (ou menor sensibilidade) ao fotoperiodo mais curto de outono (PU), mas têm desempenhos sub-ótimos em PG no ambiente favorável (solo e fotoperiodo) de PV (progênie 9) ou no ambiente de baixa fertilidade de AV (progênie 24).

Como ocorreu seleção em $F_{7: 4}$ para $P G$, os ambientes $\mathrm{PV}$ e $\mathrm{AV}$ apresentaram médias muito superiores às obtidas em $\mathrm{F}_{5: 4}$ (Yokomizo, 1994).

\subsubsection{Peso de cem sementes}

O tamanho das sementes é uma característica importante para o grupo da soja tipo alimento. Representando o tamanho das sementes pelo peso de cem sementes (PCS), existe um certo consenso em se aceitar um limite mínimo $20 \mathrm{~g}$, em condições de $13 \%$ de umidade interna das sementes, para a soja alimento, incluindo-se os tipos hortaliça ou edamame, kuromame e salada.

Para o ambiente Piracicaba-verão (PV) apresentado na Tabela 13, obtiveram-se oito progênies que não atingiram o mínimo de $\mathrm{PCS}=20 \mathrm{~g}$. Em $\mathrm{PV}$, as melhores progênies para PCS foram: $n^{\circ} 7, \operatorname{com} \operatorname{PCS}=26,1 g ; n^{\circ} 11 \operatorname{com} \operatorname{PCS}=27,8 g ; n^{\circ}$ $12 \mathrm{com}$ PCS $=25,2 \mathrm{~g}$ e $\mathrm{n}^{\circ} 16 \mathrm{com} \mathrm{PCS}=28,1 \mathrm{~g}$.

Devido as médias das progênies estarem na maioria dos casos próximas do limite aceitável, uma progênie com variabilidade alta poderá ter plantas com desempenhos superiores e também com desempenhos inferiores. No ambiente PV as maiores variabilidades foram apresentadas pelas progênies $5,6,7,13,15,16,17$ e 20, 
com desvios padrões acima de 1,0 e, portanto, maiores que a média de desvios das testemunhas $(0,8)$. Resultados interessantes foram apresentados pelas progênies 8,11 , $12,14,18$ e 21 com desvios padrões baixos e todas as plantas com PCS igual ou acima do limite mínimo desejável.

De acordo com a Tabela 14, em Piracicaba-outono (PU) as médias apresentaram uma tendência de diminuição geral, com nove progênies $(37,5 \%$ de 24$)$ obtendo valores médios de PCS abaixo do mínimo necessário. As melhores progênies foram: $\mathrm{n}^{\mathrm{o}} 6$ com PCS $=22,3 \mathrm{~g} ; \mathrm{n}^{\mathrm{o}} 7$ com $23,4 \mathrm{~g} ; \mathrm{n}^{\mathrm{o}} 12 \operatorname{com} 24,5 \mathrm{~g} ; \mathrm{n}^{\mathrm{o}} 14 \mathrm{com} 22,6 \mathrm{~g}$ e $\mathrm{n}^{\mathrm{o}} 21$ com 22,4g. Apesar dessa tendência de queda, as médias da maioria das progênies alcançaram o limite mínimo necessário para serem classificadas como soja tipo alimento (edamame, kuromame e salada); tal comportamento foi semelhante ao observado em $F_{2}$ por Destro (1991) e superior à média de $19 \mathrm{~g}$ obtida em $F_{3: 2}$ por Pacova (1992) para os topocruzamentos com 'Doko' . As progênies com maior variabilidade genética e que podem conter plantas com PCS abaixo do mínimo aceitável foram as de $\mathrm{n}^{\mathrm{o}} 10,11,12$, $15,17,23$ e 24; contrariamente, apesar das progênies 7, 14, e 16 apresentarem desvios padrões altos, suas médias inferiores ultrapassariam o mínimo de $20 \mathrm{~g}$ para o PCS. As progênies $4,6,8,9$ e 18 também apresentariam todas as plantas com médias dentro do mínimo aceitável de PCS para soja alimento com sementes grandes, com base nos desvios padrões e médias de cada uma.

Pela Tabela 15, em Anhembi-verão (AV), obtiveram-se oito progênies com PCS abaixo do mínimo adequado para soja alimento com sementes grandes, ou seja, o mesmo número observado em PV; os melhores desempenhos foram alcançados pelas progênies de $\mathrm{n}^{\mathrm{O}} 2$ com PCS $=27,3 \mathrm{~g} ; \mathrm{n}^{\mathrm{O}} 5$ com $27,1 \mathrm{~g} ; \mathrm{n}^{\mathrm{O}} 7$ com $27,3 \mathrm{~g} ; \mathrm{n}^{\mathrm{O}} 11 \mathrm{com}$ $28,3 \mathrm{~g} ; \mathrm{n}^{\mathrm{o}} 12$ com $28,3 \mathrm{~g}$ e $\mathrm{n}^{\mathrm{o}} 14 \mathrm{com} 27,6 \mathrm{~g}$, médias estas muito interessantes, pois ultrapassaram em no mínimo $7 \mathrm{~g}$ o PCS mínimo. Semelhantemente ao ocorrido nos ambientes PV e PU, as progênies 10, 19, 20 e 22, também em AV não alcançaram o limite mínimo de $20 \mathrm{~g}$ para PCS. Os desvios padrões observados foram menores em relação aos ambientes PV e PU; com isso, 16 progênies (67\% de 24) apresentaram valores de desvio padrão que possibilita a todas as plantas terem o limite mínimo de PCS; nesta última classe também estão incluídas as progênies 7,16 e 23 , possuidoras 
dos maiores desvios, mas que apresentaram médias de PCS também altas (maiores ou iguais a $20 \mathrm{~g}$ ). As progênies 7, 16, 19,20,22, 23 e 24 mostraram variabilidade genética, pois apresentaram valores de desvios padrões superiores à média dos desvios das testemunhas $\left(\mathrm{s}_{(\mathrm{PCS})}=1,2 \mathrm{~g}\right)$

Existem algumas progênies $(3,4,10,20$ e 22) que não atingiram a média mínima de $20 \mathrm{~g}$ para o PCS em todos os ambientes; apesar disso, apresentaram características de cor do tegumento amarelo e hilo marrom que torna interessante a manutenção dos mesmos no programa, pelo menos para uso futuro como parentais de outros cruzamentos.

$\mathrm{Na}$ avaliação dos ambientes em conjunto (Tabela 16), 16 progênies (67\% de 24) apresentaram médias de PCS adequadas para a soja alimento com sementes grandes, destacando-se as progênies $7,11,12,14$ e 16, com médias acima de $24,0 \mathrm{~g}$. Existem progênies com altos valores de desvio padrão, com PCS também elevado; com isso, nas progênies $2,5,6,7,8,12,14,15,16,21$ e 23 , a maioria com desvios padrões altos e todas com PCS também altos, todas as plantas atingiram o mínimo de $20 \mathrm{~g}$ para o PCS. Detectou-se variabilidade genética nas progênies $2,5,7,10,11$ e 16, com valores de desvio padrão acima da média dos desvios das testemunhas $\left(\mathrm{S}_{(\mathrm{PCS})}=2,4 \mathrm{~g}\right)$.

As melhores progênies obtidas em $\mathrm{F}_{9: 4}$ também apresentaram médias altas de PCS em F:4 (Yokomizo, 1994).

\subsection{Desempenho médio dos genótipos}

\subsubsection{Análise individual por ambiente e em relação às médias de progênies e de testemunhas}

O desempenho médio de cada progênie em relação à média de todas elas, ou em relação à média das testemunhas permite, a observação de porcentagem de superioridade ou inferioridade que cada material avaliado apresenta em relação ao padrão de comparação empregado.

$\mathrm{Na}$ Tabela 17 são apresentados os desempenhos médios em porcentagem para as progênies em relação à média geral delas, sem as testemunhas 
presentes. Para a largura visual das vagens (LVV) no ambiente Piracicaba-verão (PV), os melhores desempenhos foram obtidos pelas progênies: $n^{0} 16$, com $33,16 \%$ a mais de LVV em relação à média geral; $\mathrm{n}^{\circ} 7$, com $32,40 \%$ de superioridade; $\mathrm{n}^{\mathrm{o}} 14$, com $25,87 \%$ e $\mathrm{n}^{\circ} 2$ com 23,95\%. No ambiente Piracicaba-outono (PU) houve superioridade das progênies: $\mathrm{n}^{\mathrm{o}} 21$, com $19,64 \%$; $\mathrm{n}^{\mathrm{o}} 15$, com $17,82 \%$; $\mathrm{n}^{\mathrm{O}} 8$ e $\mathrm{n}^{\mathrm{o}} 14$, ambas com $10,57 \%$. No ambiente Anhembi-verão (AV), os melhores desempenhos foram observados nas progênies: $\mathrm{n}^{\mathrm{O}} 1$ e $\mathrm{n}^{\circ} 14$, ambas com $19,54 \%$; $\mathrm{n}^{\mathrm{o}} 21$, com $17,13 \%$; $\mathrm{n}^{\mathrm{O}} 15$, com $13,92 \%$ e $\mathrm{n}^{\circ}$ 16 , com $13,52 \%$ de superioridade em LVV. A maioria das progênies mostraram desempenhos semelhantes nos três ambientes, com exceção da progênie $\mathrm{n}^{\mathrm{o}} 1$ (com $-17,11 \%$ em PV, 1,51 em PU e 19,54\% em AV) e da progênie $n^{0} 11$ (com valores positivos e maiores que $10 \%$ em PV e AV e -8,28\% em PU); estas progênies devem ser muito sensíveis às variações ambientais.

A Tabela 18 apresenta uma comparação valiosa entre os desempenhos das progênies e das testemunhas, pois estas são cultivares de soja alimento já comerciais: oito progênies foram superiores às testemunhas, com destaque para as progênies $2,7,14,16$ e 21 , com cerca de 11 a $23 \%$ de superioridade em LVV. No ambiente $\mathrm{PU}$, as condições de outono causaram uma perda de competitividade das progênies em relação às testemunhas; com isso, apenas cinco progênies $(5,8,14,15 \mathrm{e}$ 21) foram superiores, apresentando menos de $10 \%$ de superioridade em LVV. No ambiente $\mathrm{AV}$, o desempenho das progênies foi semelhante ao observado em PU, de maneira que apenas as progênies 1 e 14 apresentaram médias superiores a $10 \%$. As amplitudes de variação do desempenho em $\mathrm{F}_{9: 4}$ foram semelhantes àquelas obtidas em $F_{5: 4}$ por Yokomizo (1994), com valores entre -30 e 30\%; as progênies 14 e 16 também se destacaram em $F_{5: 4}$; excetuando-se a progênie 2 , todas as demais também foram superiores em $\mathrm{F}_{5: 4}$ (Yokomizo, 1994).

$\mathrm{O}$ caráter valor agronômico (VA) apresentou todas as progênies com desempenhos relativos próximos de -10 a $10 \%$, exceto a progênie 10 que apresentou desempenho $34,66 \%$ superior à média geral no ambiente PV (Tabela 17). Nas condições de outono (PU) ocorreu uma maior diferenciação entre as progênies; com isso, as progênies $6,13,14,17,18$ e 24 foram superiores em $20 \%$ ou mais em relação à média 
geral. Em Anhembi (AV), duas progênies ( 9 e 22) mostraram desempenho em VA bem superior (mais de 20\%) em relação aos demais. Comparando os ambientes (Tabela 17) percebe-se que ocorreram algumas inversões de comportamento, como por exemplo: a progênie 10 com $34,66 \%$ em PV e - $12,29 \%$ em AV; a progênie 18 com $-8,64 \%$ em PV e $20,76 \%$ em PU e a progênie 19 com $-8,64 \%$ em PV e $15,15 \%$ em AV (Tabela 17). Na comparação com a média das testemunhas (Tabela 18$)$ apenas seis progênies $(25 \%$ de 24) apresentaram desempenho de VA cerca de $10 \%$ sobre a média das testemunhas, com destaque da progênie 9 com $37,71 \%$ a mais. Um fato interessante foi observado em condições de outono (PU), onde 15 progênies $(62,5 \%$ de 24$)$ superaram a média das testemunhas; houve destaque das progênies $6,9,13,14,17,18$ e 24 que ultrapassaram em mais de $20 \%$; essa superioridade em VA é explicada pela adaptação favorável das progênies e também pelo fato das testemunhas terem tido suas médias drasticamente reduzidas no outono, fato que pode ser confirmado ao se observar a média das testemunhas no outono (PU, VA $=1,18$ ) e mais de 2,00 nos ambientes de verão ( $\mathrm{PV}$ e AV). No ambiente AV (Tabela 18) seis progênies (1, 9, 13, 17, 19 e 22) apresentaram desempenho superior em 10\% sobre a média de VA das testemunhas. As progênies 6, 9 , 13,14 e 17 foram superiores em pelo menos dois ambientes, mas nenhuma foi superior em todos os três ambientes. As amplitudes de variação entre progênies enquadram-se dentro dos limites obtidos em $F_{5: 4}$ (Yokomizo, 1994). Um fato interessante é que apenas a progênie 24 , com valores positivos de desempenho nos três ambientes, não apresentou desempenho superior para VA em $F_{5: 4}$ (Yokomizo, 1994).

Para o caráter acamamento (AC) procura-se obter plantas com as menores notas. Observa-se no ambiente PV (Tabela 17) que quatro progênies destacaram-se na superioridade em AC sobre a média geral de todas as progênies: a progênie $5 \mathrm{com}-35,49 \%$; a progênie $10 \mathrm{com}-25,50 \%$; a progênie $14 \mathrm{com}-30,09 \%$ e a progênie $20 \mathrm{com}-36,03 \%$. No ambiente PU os destaques foram: a progênie $2 \mathrm{com}$ $-46,17 \%$; a progênie $5 \mathrm{com}-52,27 \%$; as progênies 15 e 16 com $-34,33 \%$ e a progênie 20 com $-50,12$; convém ressaltar que o ambiente PU foi o que apresentou menor amplitude nos desempenhos em relação aos outros ambientes testados. Nas condições de Anhembi-verão (AV) os maiores destaques foram as progênies: $\mathrm{n}^{\circ} 5$ com $-32,55 \%$; a $\mathrm{n}^{\mathrm{o}}$ 
7 com $-34,17 \%$, a n 10 com $-29,86 \%$; a $n^{-} 15$ com $-40,11 \%$; a n 19 com $-42,81 \%$ e a $\mathrm{n}^{\mathrm{o}} 21$ com $-37,41 \%$. Convém ressaltar que é importante a observação de que as progênies com os melhores desempenhos de $\mathrm{AC}$, em quase todos os casos, também tiveram menores valores de APM e notas de VA, principalmente em razão destes caracteres estarem associados. As progênies 19 e $21 \mathrm{em} \mathrm{AV}$; 5, 10 e $14 \mathrm{em} \mathrm{PV}$, foram mostraram as melhores combinações dos caracteres AC, VA e APM, ou seja, apresentaram menor AC, maior VA e valor satisfatório de APM. Também ocorreram alterações de desempenho para $\mathrm{AC}$ em função das mudanças de ambiente, podendo-se citar as progênies $6,7,10,19$ e 23 . Na Tabela 18, os melhores desempenhos para o ambiente PV foram obtidos pelas progênies $2,5,10,14$ e 20, com médias próximas ou melhores que $-20 \%$ da média de $\mathrm{AC}$ das testemunhas, as quais apresentaram uma média muito alta no ambiente $\mathrm{PV}(\mathrm{AC}=4,0)$. Em PU ocorreu uma diminuição geral de $\mathrm{AC} e$, com isso, a média das testemunhas também diminuiu; os melhores valores (menor nota de $\mathrm{AC}$ ) foram obtidos para as progênies 2,5 e 20, repetindo-se os destaques no ambiente PV. O ambiente AV apresentou um maior número de progênies com desempenho melhor (menor nota de AC) que o da média das testemunhas; com isso, as dez melhores progênies apresentaram estimativas entre $-20 \%$ e $-50 \%$. A amplitude entre os desempenhos manteve-se próximo ao obtido em $F_{5: 4}$ (Yokomizo, 1994). As progênies 7, 10, 16, 19 e 20 apresentaram maior AC em $\mathrm{F}_{5: 4}$ (Yokomizo, 1994) e, com isso, baixo desempenho.

Quando se avalia o número de dias para a maturidade (NDM), o desejável é que as plantas sejam mais precoces, sendo que em relação à média geral são importantes os valores negativos. Deste modo, no ambiente PV (Tabela 17), mostraramse melhores as progênies $2,5,7,10,11$ e 16 com valores inferiores a $-10 \%$ da média geral. As condições de outono em Piracicaba (PU) causaram uma maior uniformidade no NDM e, com isso, destacou-se apenas a progênie 1 com $-8,95 \%$ da média geral; para o ambiente $\mathrm{AV}$ aconteceu o mesmo fato e, com isso, destacaram-se somente as progênies n⿳o 2 com $-11,43 \% ; n^{0} 7$ com $-9,85 \%$ e nº 14 com $-9,06 \%$ da média geral. Como já foi discutido, as melhores condições para a máxima discriminação entre as progênies para NDM foi obtida no ambiente de alta fertilidade e fotoperiodo favorável (PV). Em 
relação à média das testemunhas (Tabela 18), no ambiente PV, maior precocidade ocorreu nas progênies $2,5,7,10$ e 16 , com estimativas próximas a $-15 \%$. No outono, as progênies tiveram médias mais próximas entre si e, com isso, em PU os melhores desempenhos ficaram próximos de $-5 \%$, destacando-se a progênie 1 com $-8,68 \%$ da média das testemunhas. No ambiente $\mathrm{AV}$, seis progênies (25\% de 24$)$ apresentaram valores próximos de $-10 \%$ em relação à média das testemunhas. Deve ser salientado que as progênies 7 e 16 foram mais precoces que a média das testemunhas em todos os ambientes. As médias obtidas de NDM foram mais precoces que as observadas em $\mathrm{F}_{5: 4}$ por Yokomizo (1994); apenas a progênie 14 apresentou-se favorável em $F_{9: 4}$ e em $F_{5: 4}$ (Yokomizo, 1994).

O caráter altura da planta na maturidade (APM) apresenta peculiaridades, pois desempenhos superiores são desejados, porém só até um certo limite a partir do qual maior APM pode levar a alto acamamento da planta em condições de verão, fato este muito indesejável. Pode-se considerar como aceitáveis médias acrescidas de até $25 \%$ em APM; acima deste limite tem-se grandes chances de acamamento em condições favoráveis como a do ambiente PV; como exemplo tem-se as progênies $13 \mathrm{e}$ 17 com desempenhos superiores a 30\% em APM associados a valores próximos de $20 \%$ a mais de $\mathrm{AC}$ em relação à média geral (Tabela 17). No ambiente $\mathrm{PV}$, pode-se selecionar as progênies 3,6, 19 com acréscimos próximos de $25 \%$ em APM sobre a média geral. Já no ambiente de outono (PU), as progênies com médias 24 a $79 \%$ de superioridade em APM apresentaram grande chance de acamarem; utilizando em conjunto os caracteres APM e AC, pode-se considerar que em PU as melhores progênies são as que estão bem próximas da média de APM. O mesmo aconteceu para o ambiente $A V$, onde as melhores progênies para APM apresentaram problemas referentes a altas médias de AC; porém, a progênie 19 com $30,45 \%$ a mais na média de APM teve $-42,81$ no acamamento, em relação a média geral; portanto, mostrou-se promissora em porte elevado sem tendência a acamar. Como tendência geral, pode-se considerar que as melhores progênies apresentaram cerca de 10\% a mais em APM, relativamente à média geral (Tabela 17).

Também é necessário associar APM com AC na análise das progênies em relação à média das testemunhas (Tabela 18). As progênies com $20 \%$ a $50 \%$ a mais 
de APM em relação à média das testemunhas apresentaram altas chances de acamamento no campo. Novamente, os melhores genótipos foram os que apresentaram estimativas próximas de $10 \%$ de acréscimo em APM sobre a média das testemunhas sem problemas com acamamento, destacando-se as progênies $8,12,18,23$ e 24 . Os maiores desempenhos no outono (PU) variaram de 54,06\% a 123,36\% de acréscimo em APM, porém estes desempenhos foram associados com $40 \%$ ou mais de acréscimo em acamamento. As progênies com desempenho mínimo alcançaram $50 \mathrm{~cm}$ de APM (superioridade próxima de $50 \%$ sobre a média das testemunhas) também tiveram altos valores de $\mathrm{AC}$; com isso, a seleção de progênies adaptadas ao ambiente $\mathrm{PU}$ ficou dificultada. Cinco progênies $(1,19,22,23$ e 24$)$ destacaram-se por apresentarem valores de APM entre $15 \%$ e $40 \%$ superiores à média das testemunhas e baixos valores para o acamamento. A amplitude da superioridade das progênies em APM sobre as testemunhas foram semelhantes aos resultados obtidos em $F_{5: 4}$ por Yokomizo (1994), excetuando-se apenas o ambiente PU com valores de APM de até 123\% superiores à média das testemunhas. Todas as progênies $F_{9: 4}$ superiores em APM foram também em $\mathrm{F}_{5: 4}$ (Yokomizo, 1994), com exceção da progênie 24. As médias gerais das progênies em APM foram menores em $F_{9: 4}$ do que em $F_{5: 4}$ (Yokomizo, 1994); ocorreu o mesmo com as testemunhas.

Para o caráter produtividade de grãos (PG), a Tabela 17 revela que no ambiente favorável PV as melhores progênies apresentaram médias no mínimo $23 \%$ superiores à média geral, com destaque da progênie 13 com $64,19 \%$ de superioridade. Nas condições de outono (PU) ocorreram mudanças significativas no comportamento das progênies, com variações muito acima ou muito abaixo da média geral; com isso, sete progênies tiveram médias de PG no mínimo $48 \%$ superiores à média geral, com destaque da progênie 9 com 109,26\% de superioridade em PG sobre a média geral. Esta mesma progênie 9 também se destacou no ambiente AV com $63,82 \%$ de desempenho superior em PG, em conjunto com as progênies: $n^{\mathrm{o}} 12$ com $46,41 \%$; $\mathrm{n}^{\mathrm{o}} 13$ com $40,04 \%$ e n⿳0 22 com $80,56 \%$. Analisando-se os desempenhos das progênies em PG nos três ambientes, pode-se observar que as progênies 3 e 9 foram superiores em dois dos três ambientes testados, enquanto que as progênies 12,13 e 22 foram superiores em todos os 
três ambientes. Apesar do fato de existirem progênies com médias que não foram as melhores em comparação às demais, as plantas com PG próximas da média geral dos ambientes PV $(98,42 \mathrm{~g})$ e $\mathrm{AV}(75,27 \mathrm{~g})$ ainda podem ser consideradas promissoras. $\mathrm{Na}$ análise das progênies em relação à média das testemunhas (Tabela 18) foram obtidas 13 progênies (54\% de 24$)$ com desempenho superior em PG, com destacando-se as progênies $7,12,13,21$ e 24 com $30 \%$ ou mais de superioridade. É interessante notar que no outono (PU) ocorreram 21 progênies $(87,5 \%$ de 24$)$ superiores à média das testemunhas. As condições adversas do outono (PU) reduziu muito a $\mathrm{PG}$ das progênies e das testemunhas e, por isso, torna-se necessário considerar um limite alto de cerca de $500 \%$ de superioridade sobre a média de PG das testemunhas, para que uma progênie seja considerada economicamente viável; a progênie 9 foi a que mais se aproximou deste limite, pois alcançou $423,39 \%$ de superioridade em PG sobre as testemunhas. No ambiente AV, 16 progênies (67\% de 24) mostraram PG superiores à média de testemunhas, com destaque para as progênies $9,12,13$ e 22 com $50 \%$ ou mais de superioridade.

Na comparação com a média de PG das testemunhas (Tabela 18) os resultados foram semelhantes àqueles obtidos em $F_{5: 4}$ por Yokomizo (1994), com exceção dos desempenhos obtidos no outono (PU); entre as progênies destacadas, apenas a progênie 24 não havia alcançado PG elevada em $\mathrm{F}_{5: 4}$ por Yokomizo (1994).

Para o tamanho das sementes, avaliado pelo peso de cem sementes (PCS), observa-se na Tabela 17 três destaques no ambiente PV com mais de $20 \%$ de superioridade sobre a média geral, correspondentes às progênies 7,11 e 16. Nas condições de outono (PU), as diferenças existentes entre as progênies foram reduzidas, de maneira que os desempenhos foram muito semelhantes e na maioria dos casos não ultrapassou a $10 \%$ de superioridade, sobressaindo-se a progênie 7 com $14,01 \%$ e a progênie 14 com 10,11\%. Para o ambiente de Anhembi-verão (AV), as progênies 2, 5, 7, 11,12 e 14 foram as melhores com mais de $20 \%$ de acréscimo em PCS sobre a média geral. Pela Tabela 17, as médias de PCS das progênies nos três ambientes foram adequadas para a soja alimento com sementes grandes, pois todas as progênies ultrapassaram o limite mínimo de $\mathrm{PCS}=20 \mathrm{~g}$. A Tabela 18 mostra a análise das progênies 
em relação à média das testemunhas. Para PCS, as progênies com valores iguais ou maiores que $-8 \%$ de superioridade sobre a média das testemunhas podem ser selecionadas como soja alimento, pois elas atingiram o limite mínimo de PCS $=20 \mathrm{~g}$. No ambiente PV, nove progênies $(37,5 \%$ de 24$)$ foram superiores, com destaque para as progênies 7, 11 e 16 com mais de 19\% de superioridade em PCS sobre a média das testemunhas. No outono (PU), as progênies que apresentaram superioridade acima de $4,28 \%$ tiveram médias iguais ou maiores que ao mínimo de $\mathrm{PCS}=20 \mathrm{~g}$ e, com isso, 15 progênies $(62,5 \%$ de 24$)$ mostraram-se promissoras, destacando-se as progênies $6,7,12$, 14 e $21 \mathrm{com}$ mais de $16 \%$ sobre a média das testemunhas. No ambiente AV, um total de 11 progênies $(45,8 \%$ de 24$)$ apresentaram desempenho superior à médias das testemunhas, sobressaindo-se as progênies $2,5,7,11,12$ e 14 com valores de PCS no mínimo $28 \%$ a mais que as testemunhas. Deve-se ressaltar as progênies $6,7,12$ e 14 com os melhores valores de PCS em todos os três ambientes, além disso, outras progênies, com desempenhos próximos de $-5 \%$ em relação às testemunhas, também apresentaram valores de PCS adequados para a soja alimento. A amplitude obtida no ambiente favorável de PV foi semelhante àquela obtida em $\mathrm{F}_{5: 4}$ por Yokomizo (1994), enquanto que nos dois ambientes restritivos (PU e AV) ocorreram diferenças menores entre as superioridades das progênies sobre as testemunhas. As progênies 11 e 14 também foram as melhores em $\mathrm{F}_{5: 4}$; entre os destaques, a progênie 2 não havia mostrado superioridade em $\mathrm{F}_{5: 4}$ ( Yokomizo, 1994).

\subsubsection{Análise conjunta de ambientes e relações com as médias de progênies e de testemunhas}

$\mathrm{Na}$ análise conjunta dos três ambientes (Tabela 19) para o caráter largura visual das vagens (LVV), o desempenho das progênies em relação à média geral, apresentou como mais promissoras as mesmas observadas para o ambiente PV (Tabelas 17 e 18), destacando-se as progênies $2,7,14,15,16$ e 21 , com superioridade maiores que $10 \%$ em relação à média geral. Na Tabela 19 para LVV observa-se que ocorreu coincidência das progênies com os dois referenciais (média geral das progênies e média 
das testemunhas), destacando-se as progênies $7,14,15,16$ e 21 , com superioridade mínima de $6 \%$. A amplitude dos desempenhos das progênies $F_{9: 4}$ diminuiu em relação à geração $\mathrm{F}_{5: 4}$ (Yokomizo, 1994), mas as progênies superiores foram em ambas gerações.

Para o caráter valor agronômico (VA, Tabela 19), no ambiente favorável PV, observa-se que sete progênies $(6,9,10,13,14,17$ e 22) foram melhores em comparação com média geral e com a média das testemunhas, com desempenhos no mínimo $8 \%$ superiores ao referencial adotado. As progênies 18 e 19 se destacaram apenas quando comparadas com a média das testemunhas. Com exceção da progênie 10, as demais seis progênies $F_{9: 4}$ também foram superiores em $F_{5: 4}$ (Yokomizo, 1994).

Para o acamamento (AC, Tabela 19), com os três ambientes juntos, as progênies mostraram desempenhos semelhantes em relação aos dois referenciais de comparação (média geral das progênies e médias das testemunhas); deste modo, os destaques foram as progênies $2,5,14,15$ e 20 com estimativas maiores que $-23 \%$ de superioridade, pois valores menores são os desejáveis para o caráter AC. Dentre os cinco destaques em $F_{9: 4}$ apenas a progênie $n^{0} 2$ não apresentou desempenho adequado em $F_{5: 4}$ (Yokomizo, 1994).

Para o caráter número de dias para a maturidade (NDM, Tabela 19), ocorreu pequena variação entre as médias das progênies e, com isso, as mais precoces foram as progênies $2,7,14$ e 16 , com valores entre $-6 \%$ e $-11 \%$ para NDM. Deste modo as progênies mais precoces para os três ambientes em conjunto foram as mesmas observadas para cada ambiente individualmente (Tabelas 17 e 18). Porém, somente as progênies 2 e 14 foram mais precoces em $F_{9: 4}$ do que em $F_{5: 4}$ (Yokomizo, 1994).

A Tabela 19 também revela a já discutida (análises individuais de ambientes) associação positiva e desfavorável entre os caracteres APM e AC. As progênies $1,6,8,10,19,23$ e 24 apresentaram ganhos de desempenho para o caráter APM e valores aceitáveis de $\mathrm{AC}$, com destaque da progênie 19 para APM com desempenho superior igual a $20,40 \%$ em relação à média geral e de $34,45 \%$ em relação à média das testemunhas e menores $\mathrm{AC}$ que os mencionados referenciais. Dentre os sete destaques $(1,6,8,10,19,23$ e 24$)$ em $F_{9: 4}$, somente a progênie 24 não foi superior em $F_{5: 4}$ (Yokomizo, 1994). 
Para a produtividade de grãos ( $\mathrm{PG}$, Tabela 19), nos três ambientes juntos, os melhores desempenhos foram apresentados pelas progênies $3,9,12,13,18,22$ e 24 , com acréscimos de $19 \%$ a $76 \%$ sobre as médias geral e das testemunhas. Dentre os sete destaques relatados em $F_{9: 4}$, apenas a progênie 24 não foi superior para $P G$ em $F_{5: 4}$ (Yokomizo, 1994). Considerando-se uma produtividade de $50 \mathrm{~g} / \mathrm{cova}$ de planta individual como um mínimo aceitável, todas as progênies com estimativas positivas de desempenho para $\mathrm{PG}$ em relação aos referenciais seriam consideradas adequadas.

Para o tamanho das sementes avaliado pelo peso de cem sementes (PCS, Tabela 19), com PCS=20g sendo o mínimo aceitável, tem-se que todas as progênies com desempenho positivo podem ser considerados adequadas. As melhores progênies foram: $1,2,5,6,7,8,9,11,12,14,1516$, quando comparadas com a média geral e incluíram-se as progênies 21 e 23 quando comparado com a média de testemunhas. Em consequência da prática de seleção entre plantas dentro de progênies ao longo das gerações, as progênies $2,3,4$ e 6 que não possuíam média de $P C S \geq 20 \mathrm{~g}$ em $F_{5: 4}$ (Yokomizo, 1994), ultrapassaram este limite em $F_{9: 4}$, alcançando potencial para serem selecionadas nesta geração.

\subsection{Comparação de médias e agrupamento das progênies pelo teste de Scott- Knott}

As comparações e classificações das progênies pelo teste de ScottKnott são apresentadas nas Tabelas 20 a 23 para os três ambientes, individualmente e em conjunto, sendo que nas discussões serão apresentados as progênies dos melhores grupos apenas.

No ambiente favorável PV (Tabela 20), a classificação de Scott-Knott conseguiu distinguir quatro grupos de progênies para o caráter LVV, sendo que o grupo A apresentou médias de LVV entre 3,13 e 3,45 e incluiu as progênies 2, 7, 14, 16 e 21; o grupo B teve médias de LVV entre 2,71 e 3,00, incluindo cinco progênies $(5,8,11,12$ e 15), e três (Céu Azul, IAC PL-1 e Tamba) das quatro testemunhas; o grupo C, com médias de LVV entre 2,41 e 2,60 foi formado por cinco progênies $(3,4,6,17$ e 20$)$ e a 
testemunha 'Nimame'; o grupo D, com médias de LVV entre 2,00 e 2,33, foi formado por nove progênies. Pela Tabela 21, o ambiente estressante (PU) causou menor alteração nas médias entre as progênies para LVV, em relação ao ambiente favorável (PV), de maneira que foram discriminados três grupos, o grupo $\mathrm{A}$, com as maiores médias de LVV apresentou valores de 2,66 a 3,30, sendo formado por 17 progênies, destacando-se as progênies $5,8,14,15,20$ e 21; o grupo $\mathrm{A}$ também incluiu as quatro testemunhas, com suas médias entre 2,85 e 3,15 . Os grupos $\mathrm{B}$ e $\mathrm{C}$ juntos compreenderam sete progênies com médias de LVV variando de 2,05 a 2,60.

No ambiente AV (Tabela 22) foram formados três grupos: o grupo A apresentou médias entre 2,73 e 2,98, sendo formado pelas progênies $1,5,7,11,14,15$, 16,21 e as testemunhas 'IAC PL-1' e 'Tamba'; os grupos B e C compreenderam médias de LVV entre 2,65 e 2,00 e 16 progênies.

Os ambientes em conjunto (Tabela 23) permitiram a formação de quatro grupos, sendo que no grupo A com maior LVV as médias ficaram entre 2,90 e 3,10 , sendo incluídas seis progênies $(2,7,14,15,16 \mathrm{e} 21) \mathrm{e}$ as testemunhas 'IAC PL-1' e 'Tamba'. O grupo B teve médias de LVV entre 2,60 e 2,82, sendo formado por nove progênies $(1,4,5,6,8,11,12,17$ e 20) e as testemunhas 'Céu Azul' e 'Nimame'. O grupo $\mathrm{C}$ teve médias de LVV entre 2,38 e 2,47 e compreendeu quatro progênies $(3,19$, 23 e 24). $O$ grupo $D$, de pior desempenho, teve médias entre 2,06 e 2,24 , incluindo cinco progênies. Comparativamente foram obtidos menos grupos em $\mathrm{F}_{9: 4}$ do que o obtido em $F_{3: 2}$ (Pacova, 1992) e em $F_{5: 4}$ (Yokomizo, 1994). Nenhum destaque na geração $F_{9: 4}$ apresentou desempenho superior em $F_{3: 2}$ (Pacova, 1992). A progênie 14 da geração $F_{9: 4}$ também se destacou em $F_{5: 4}$ (Yokomizo, 1994).

Em relação ao caráter valor agronômico (VA, Tabela 20), para o ambiente favorável $\mathrm{PV}$, foram obtidos três grupos, o grupo $\mathrm{A}$ contendo apenas a progênie $10 \mathrm{com}$ média igual a 2,83 , valor este bem superior ao VA das demais progênies. $O$ grupo $B$, cujas médias variaram de 2,12 a 2,29, foi formado pelas progênies $1,5,6,9,12,13,14,20,22$ e pelas testemunhas 'Céu Azul' e 'Nimame'. As 14 demais progênies restantes e, as testemunhas 'IAC PL-1' e 'Tamba', formaram o grupo $\mathrm{C}$, de pior desempenho, com médias de VA entre 1,79 e 2,11. No ambiente de outono (PU, Tabela 
21) apenas dois grupos foram formados: o grupo $\mathrm{A}$ apresentou 13 progênies com médias variando de 1,36 a 1,79; o grupo $B$, com 11 progênies apresentou médias de 1,00 a 1,24, incluindo as testemunhas 'Céu Azul', 'IAC PL-1' e 'Tamba'. As melhores médias de VA $(1,69$ a 1,79) ocorreram nas progênies 13,14 e 17. O ambiente Anhembi-verão (AV) proporcionou a formação de dois grupos: o grupo A com médias entre 2,04 e 2,80, foi formado por 15 progênies e três testemunhas (Céu Azul, IAC PL-1 e Nimame), com destaque para as progênies $1,8,9,13,17,19$ e 22; o grupo $B$, com médias entre 1,31 e 1,93 , foi constituído por nove progênies e pela testemunha 'Tamba'. A análise conjunta dos três ambientes (Tabela 23) permitiu a formação de dois grupos para o caráter VA: no grupo $\mathrm{A}$, com as melhores médias $(1,78$ a 2,06$)$, incluiu 15 progênies e duas testemunhas (Céu Azul e Nimame), destacando-se as progênies 6, 9, 10, 13, 14, 17 e 22; o grupo B, com médias entre 1,43 a 1,73, incluiu nove progênies e as testemunhas 'IAC PL-1' e 'Tamba'; as médias de VA para os três ambientes em conjunto foram próximas entre os grupos. A redução do número de grupos formados em $F_{9: 4}$ em relação às gerações $F_{3: 2}$ (Pacova, 1992) e $F_{5: 4}$ (Yokomizo, 1994) deve ter sido consequência da seleção efetuada durante as gerações de endogamia. Excetuando-se progênie 14, todas as demais da geração $F_{9: 4}$ também foram destaques em $F_{5: 4}$ (Yokomizo, 1994), enquanto que em $F_{3: 2}$ (Pacova, 1994) houve coincidência de destaque apenas para as progênies 6, 17 e 19.

Para o caráter acamamento (AC, Tabela 20), no ambiente favorável (PV) foram obtidos apenas dois grupos: no grupo A foram englobados 16 progênies e as quatro testemunhas, com médias entre 3,61 e 4,46; o grupo B, cujas médias variaram de 2,37 a 3,28, compreendeu as progênies de melhor desempenho (valores menores) de $\mathrm{AC}$, sendo às progênies $2,4,5,6,10,14,15$ e 20. Já no ambiente estressante (PU, Tabela 21 ), as progênies foram igualmente divididas em dois grupos: o grupo $\mathrm{A}$ apresentou médias altas de $\mathrm{AC}$ variando de 2,90 a 4,13 e o grupo $\mathrm{B}$ com médias favoráveis de $\mathrm{AC}$ de 1,33 a 2,63 , incluindo as melhores progênies $(2,5,15$ e 20$)$ e as quatro testemunhas. $\mathrm{Na}$ Tabela 22, no ambiente $\mathrm{AV}$, não foi possivel a formação de grupos, apesar das diferenças significativas a $5 \%$ no teste $F$ entre progennies (Tabela 8 ). Avaliando-se todos os ambientes em conjunto (Tabela 23) houve a formação de quatro grupos para o caráter $\mathrm{AC}$, sendo que os grupos $\mathrm{A}$ e $\mathrm{B}$ com médias altas de $\mathrm{AC}(3,01$ a 3,78), foram compostos 
por 11 progênies e as testemunhas 'Tamba' e Nimame'; o grupo C com oito progênies e médias entre 2,41 e 2,74, incluiu as testemunhas 'Céu Azul' e 'IAC PL-1', e o grupo D com melhor desempenho, apresentou média de AC entre 1,66 e 2,12, sendo formado pelas progênies $2,5,14,15$ e 20 . Houve um menor número de grupos formados em $F_{9: 4}$ relativamente à geração $\mathrm{F}_{5: 4}$ (Yokomizo, 1994); certamente este decréscimo de variabilidade para $\mathrm{AC}$ e outros caracteres agronômicos é consequência da prática de seleção entre as gerações $F_{5: 4}$ e $F_{9: 4}$. As progênies 5, 14, 15 e 20 já haviam sido destaques em $F_{5: 4}$ (Yokomizo, 1994).

Para o caráter número de dias para a maturidade (NDM, Tabela 20), no ambiente $\mathrm{PV}$, foi obtida um número maior de grupos, seis no total. $\mathrm{O}$ grupo $\mathrm{A}$, com média de plantas mais tardias (141 dias) incluiu apenas a progênie 17 . O grupo B com quatro progênies $(3,18,19$ e 24) apresentou médias de 132 a 136 dias, incluindo a testemunha 'IAC PL-1'. O grupo C com dez progênies (4, 6, 8, 9, 12, 13, 20, 21, 22 e 23) teve médias variando de 124 à 129 dias, incluindo as testemunhas 'Céu Azul' e 'Tamba'. $\mathrm{O}$ grupo $\mathrm{D}$ apresentou as progênies 1 e 15 com média de NDM igual 121 dias e a testemunha 'Nimame' com 119 dias. O grupo E incluiu a progênie 14 com NDM de 116 dias. $\mathrm{O}$ grupo $\mathrm{F}$, mais precoce e de grande interesse, com ciclo médio entre 105 a 110 dias, foi formado pelas progênies $2,5,7,11$ e 16. Nas condições de outono (PU, Tabela 21) ocorreu uma diminuição média de 13 dias no ciclo, em relação ao ambiente favorável PV, de maneira que as médias das progênies foram mais semelhantes entre elas e, com isso, apenas dois grupos foram formados: o grupo $\mathrm{A}$, mais tardio, apresentou 11 progênies com médias variando de 111 a 120 dias e as testemunhas 'IAC PL-1' e 'Tamba'; o grupo B foi formado por 13 progênies mais precoces com médias entre 100 e 110 dias, incluindo as progênies $1,7,8,14,16,19$ e as testemunhas 'Céu Azul' e 'Nimame'. No ambiente AV (Tabela 22) houve a formação de quatro grupos: o grupo A mais tardio composto por cinco progênies apresentou médias entre 138 e 146 dias; o grupo B incluiu quatro progênies e médias de NDM entre 130 e 134 dias e as testemunhas 'IAC PL-1' e 'Tamba'; o grupo C com sete progênies apresentou médias de NDM entre 122 e 128 dias e incluiu também duas testemunhas (Céu Azul e Nimame); o grupo D, mais precoce, com médias entre 112 e 119 dias foi formado pelas progênies 2 , 
$5,7,10,11,12,14$ e 16. Pela Tabela 23, a análise conjunta dos três ambientes permitiu, de maneira semelhante ao ambiente PV, a formação de um grande número de grupos; os grupos B e A com médias de NDM entre 123 e 132 dias foram compostos por sete progênies e duas testemunhas (IAC PL-1 e Tamba); o grupo C com médias de 119 a 122 dias foi formado por nove progênies $(4,8,9,12,13,15,20,21$ e 22) e a testemunha 'Céu Azul'; o grupo D apresentou médias entre 114 e 117 dias e incluiu três progênies $(1,10$ e 11), e a testemunha Nimame'; o grupo $E$, mais precoce, apresentou médias de NDM entre 108 a 112 dias e foi formado pelas progênies $2,5,7,14$ e 16 .

$O$ número de grupos formados na geração $F_{9: 4}$ foi relativamente próximo daqueles obtidos na geração $F_{5: 4}$ (Yokomizo, 1994). Todavia, na geração $F_{3: 2}$ obteve-se maior número de grupos (Pacova, 1992). Considerando-se o controle genético do NDM, com pelos menos cinco genes principais envolvidos (Buzzell, 1971; Buzzell \& Voldeng, 1980; Toledo \& Kiihl, 1982a, 1982b; McBlain \& Bernard, 1987; Bonato, 1989) pode-se considerar que em $F_{3: 2}$ a maioria dos efeitos (mesmos os de genes recessivos) puderam expressar-se, resultando na maior variabilidade observada para NDM em F $F_{3: 2}$ (Pacova, 1992). A seleção realizada para vários caracteres deve ter reduzido a variabilidade em $F_{9: 4}$, conforme relato de Yokomizo (1994). No entanto, a partir de $\mathrm{F}_{6: 4}$ a seleção praticada para vários caracteres deve ter sido neutra para NDM, fato que poderia explicar a semelhança de números de grupos obtidos em $F_{5: 4}$ e $F_{9: 4}$.

Para o caráter altura da planta na maturidade (APM, Tabela 20), no ambiente favorável PV foram formados três grupos: o grupo A com plantas de maior porte, cujas médias variaram de 73,4 a $81,4 \mathrm{~cm}$, incluiu cinco progênies $(3,6,13,17 \mathrm{e}$ 19); o grupo B incluiu nove progênies com médias entre 56,8 e $68,6 \mathrm{~cm}$ e duas testemunhas (Céu Azul e Tamba); e o grupo C, foi formado por dez progênies com médias entre 37,3 e $52,9 \mathrm{~cm}$ e as testemunhas 'IAC PL-1' e Nimame'; é importante ressaltar que a segunda melhor progênies do grupo $\mathrm{C}$ apresenta média de APM = $52,5 \mathrm{~cm}$, porte este que ainda pode ser considerado aceitável para seleção em cultivo com covas. Para APM em condições de outono (PU, Tabela 21) foram formados quatro grupos: o grupo A com as melhores médias, apresentou apenas as progênies: progênie 3 com $72,2 \mathrm{~cm}$ e a 13 com $60,4 \mathrm{~cm}$; o grupo B com médias de APM entre 43,8 e $55,8 \mathrm{~cm}$ foi 
composto por oito progênies, sendo que três progênies $(6,11$ e 18) apresentaram altura de planta aceitável; os grupos C e D foram compostos por 14 progênies, com a média variando de 41,5 a $23,6 \mathrm{~cm}$, e as quatro testemunhas; médias esta que refletem uma sensibilidade acentuada ao fotoperíodo do outono pelas progênies. Pela Tabela 22, nas condições de verão $(\mathrm{AV})$, foram formados quatro grupos: o grupo $A$, com médias entre 66,0 e $74,4 \mathrm{~cm}$, foi formado pelas progênies $3,6,13,17,18$ e 19; o grupo B, com médias entre 54,7 e $62,5 \mathrm{~cm}$, incluiu seis progênies $(1,8,9,22,23$ e 24); os grupos (A e B) mostraram possuir valores mais apropriados de APM. Os grupos C e D, apresentaram médias entre 50,1 e $30,6 \mathrm{~cm}$, desempenho que pode ser considerado inadequado para a soja tipo alimento nas condições de verão, as quatro testemunhas foram incluídas no grupo C. Na análise conjunta dos ambientes (Tabela 23) foram formados cinco grupos: o grupo A, com médias de APM entre 63,2 e 73,2cm foi formado pelas progênies $3,6,13$, 17 e 18; o grupo B, com médias entre 56,1 e $60,1 \mathrm{~cm}$, foi constituído pelas progênies 1 , 9,19 e 22; o grupo $C$, com médias entre 50,7 e $53,4 \mathrm{~cm}$, incluiu as progênies $8,10,23$ e 24; pode-se considerar que os grupos A, B, C possuem plantas com valores mais adequados de APM; já o grupo D, com médias entre 41,1 e 49,0 cm (incluindo as quatro testemunhas) e o grupo E com médias muito baixas (31,0 a 39,3cm) de APM, formado por oito progênies, apresentaram porte de planta bastante inferior àqueles dos grupos $\mathrm{A}$, B, C. Ocorreu redução no número de grupos formados na geração $F_{9: 4}$ em relação aos obtidos em $\mathrm{F}_{3: 2}$ (Pacova, 1992). A maioria dos destaques em $\mathrm{F}_{9: 4}$ foram classificados em grupos de APM intermediária em $\mathrm{F}_{5: 4}$ (Yokomizo, 1994); além disso, as progênies $11 \mathrm{e}$ 13 foram classificadas em grupos de menor APM em $F_{3: 2}$ enquanto que as demais apresentaram bom desempenho (Pacova, 1992).

Para o caráter produtividade de grãos ( $\mathrm{PG}$, Tabela 20), no ambiente favorável PV, foram formados quatro grupos: o grupo A, altamente produtivo, englobou médias de 131,5 a $161,0 \mathrm{~g} /$ cova de planta individual, sendo formado pelas progênies 12 , 13, 22 e 24; o grupo B com nove progênies $(1,3,6,8,9,17,18,20$ e 21) teve médias de PG entre 98,9 e 124,0 g, incluindo as testemunhas 'IAC PL-1' e 'Tamba'; o grupo C, com cinco progênies $(4,10,14,19$ e 23) e a testemunha 'Céu Azul', teve médias entre 77,7 e 92,2g; podendo-se considerar os grupos A, B, C como possuidores de plantas com PG 
apropriado para a soja tipo alimento. Entretanto o grupo D composto por seis progênies com médias entre 38,1 e $70,5 \mathrm{~g}$, reuniu as plantas com PG relativamente insatisfatória.. No ambiente estressante de outono (PU, Tabela 21), apenas dois grupos foram obtidos: o grupo A, mais produtivo para as condições de outono, porém com PG insatisfatório para o referencial de verão, apresentou médias entre 26,70 e $50,80 \mathrm{~g}$, e incluiu 12 progênies com destaque para as progênies $3,9,13,18$ e 24; o grupo $\mathrm{B}$, com médias insatisfatórias de PG entre 3,53 e $21,30 \mathrm{~g}$, foi formado pelas outras 12 progênies e as quatro testemunhas. O ambiente AV (Tabela 22) proporcionou a formação de três grupos: o grupo A, com as melhores produtividades (médias entre 105,5 e 135,9g), foi formado pelas progênies $9,12,13$ e 22; o grupo $\mathrm{B}$, com médias de $\mathrm{PG}$ entre 63,8 e 88,4g, concentrou a maior parte das progênies (14) e três testemunhas (Céu Azul, IAC PL-1 e Nimame); e o grupo $C$, com as piores médias $(37,3$ a $59,1 \mathrm{~g})$ foi formado por seis progênies e a testemunha 'Tamba'. Somente os grupos A e B no ambiente AV podem ser considerados com médias satisfatórias de PG. Para os três ambientes em conjunto (Tabela 23) foram obtidos quatro grupos de PG: o grupo A apresentou médias entre 92,1 e 101,5g e foi composto pelas progênies $9,12,13,22$ e 24; o grupo B com seis progênies $(3,6,8,17,19$ e 20$)$, teve médias entre 69,8 e 79,9g; o grupo $\mathrm{C}$ incluiu sete progênies $(1,4,10,14,19,21$ e 23$)$, tendo médias de 55,1 a $62,9 \mathrm{~g}$ e três testemunhas (Céu Azul, Tamba, IAC PL-1); e o grupo D com seis progênies e médias $(29,3$ a 48,7g) insatisfatórias de PG, incluiu a testemunha 'Nimame'. Números semelhantes de grupos foram obtidos em $F_{3: 2}$ (Pacova, 1992) e em $F_{5: 4}$ (Yokomizo, 1994). As progênies 18, 22 e 24 da geração $F_{9: 4}$ foram superiores também em $F_{5: 4}$ (Yokomizo, 1994), enquanto que em $F_{3: 2}$ (Pacova, 1992) as progênies 3 e 22 também já haviam se destacado para PG.

Para o tamanho das sementes (PCS, Tabela 20) no ambiente PV, foram obtidos seis grupos: o grupo A com apenas duas progênies (11 e 16) e médias de 27,8 a 28 , 1 ; o grupo B com a progênie 7 e média de $26,1 \mathrm{~g}$, incluiu também a testemunha 'IAC PL-1'; o grupo C com e seis progênies e a testemunha 'Tamba' apresentou médias entre 22,5 e 25,2g; o grupo $\mathrm{D}$ com nove progênies e médias entre 19,5 a $21,4 \mathrm{~g}$, incluiu a testemunha 'Céu Azul'; pode-se considerar os grupo A, B, C, D possuidores de plantas com PCS aceitável para a soja alimento de sementes grandes. O grupo $\mathrm{E}$ foi composto 
por cinco progênies com médias de 15,5 a $18,1 \mathrm{~g}$ e o grupo $\mathrm{F}$ teve apenas a progênie 10 com média 12,8g; apesar das plantas dos grupos $\mathrm{E}$ e $\mathrm{F}$ possuírem tamanho inadequado de sementes, algumas progênies apresentaram médias favoráveis de PG e para caracteres de cor do hilo e tegumento. Nas condições de outono (PU, Tabela 21) observaram-se diferenças menores entre os genótipos e com isso foram formados dois grupos para PCS; o grupo A, formado por 13 progênies, com médias entre 20,5 a $24,5 \mathrm{~g}$, com destaque para as progênies $6,7,9,12,14$ e 21, este grupo incluiu a testemunha 'Tamba'; o grupo B foi composto por 11 progênies com médias de 16,5 a $20,2 \mathrm{~g}$, incluindo três testemunhas (Céu Azul, IAC PL-1 e Nimame). Quatro grupos foram formados para PCS, no ambiente AV (Tabela 22): o grupo A, com médias entre 26,4 e $28,3 \mathrm{~g}$, foi formado pelas progênies $2,5,7,11,12,14$ e 16; o grupo $B$ foi formado por três progênies $(1,6$ e 15), apresentando médias entre 23,8 e 25,1 g, e incluiu a testemunha 'Tamba'; o grupo $\mathrm{C}$ teve seis progênies $(3,8,9,13,21$ e 23$)$, com médias entre 20,2 e $21,7 \mathrm{~g}$ e duas testemunhas (Céu Azul e IAC PL-1); o grupo D, cujas médias ficaram entre 17,8 e 19,3g, foi o pior grupo para PCS e incluiu oito progênies, além da testemunha 'Nimame'. Na análise conjunta dos três ambientes (Tabela 23) para o caráter PCS, foram obtidos quatro grupos: o grupo A, com médias entre 24,7 e $26,0 \mathrm{~g}$, foi formado pelas progênies 7,11 , 12,14 e 16; o grupo $B$ foi formado por cinco progênies $(1,2,5,6$ e 15) e duas testemunhas (IAC PL-1 e Tamba), com médias entre 21,8 e 23,5g. Os grupos A e B incluíram progênies promissoras para soja tipo alimento de sementes grandes, pois os demais grupos (C e D) tiveram médias de PCS entre 21,4 e 16,7g. O número de grupos obtidos em $F_{9: 4}$ foi semelhante ao obtido em $F_{3: 2}$ por Pacova (1992), porém menor daquele obtido em $F_{5: 4}$ (Yokomizo, 1994). As progênies 7, 9, 11, 12, 14 e 16 da geração $\mathrm{F}_{9: 4}$ também foram superiores para PCS em $\mathrm{F}_{3: 2}$ (Pacova, 1992). No entanto, na geração $\mathrm{F}_{5: 4}$ (Yokomizo, 194), apenas a progênie 14 havia se destacado para PCS; os demais destaques em $\mathrm{F}_{9: 4}$ foram intermediários na geração $\mathrm{F}_{5: 4}$.

Na Figura 1 são apresentados os histogramas para os caracteres PG, PCS e VA: para o caráter PG, os materiais superiores e mais estáveis (ou seja que menos mudaram de grupos de classificação de Scott-Knott) foram as progênies $9,12,13,22$ e 24, com classificação no grupo A, conforme discussão anterior; para o caráter PCS, 
nenhuma linhagem foi totalmente estável, mas os materiais que mais se destacaram foram as progênies $7,11,12,14$ e 16; o caráter VA apresentou menor estabilidade em relação aos outros dois caracteres (PG e PCS), pois um número maior de progênies mudou de grupo de classificação de Scott-Knott de um ambiente para outro; para VA as progênies mais promissoras e estáveis foram: $3,6,9,10,13,17,18,19$ e 24 . A eficiência do uso de histograma associado ao agrupamento de médias de Scott-Knott como medida da estabilidade relativa dos genótipos em ambientes diversos, será discutida adiante no item 4.10 (Avaliação da interação $\mathrm{G} \times \mathrm{E}$ pela ecovalência).

\subsection{Correlações fenotípicas de Pearson}

\subsubsection{Para os grupos de progênies e de testemunhas}

As estimativas de correlações fenotípicas para os grupos progênies e testemunhas são apresentadas na Tabela 24. Em geral as correlações mostraram tendências semelhantes quando estimadas ao nível de plantas individuais ou em relação às médias de repetições, mas existiram correlações significativas obtidas para as plantas individuais que não foram significativas quando avaliadas com base em médias. Conforme Johnson et al. (1955) e Bravo et al. (1980) o uso das médias de parcelas ou de progênies tende a eliminar possiveis erros ou desvios indesejáveis e, assim, aumenta a precisão destas estimativas; deste modo, a discussão será baseada apenas nas estimativas obtidas para as médias de plantas.

Para os grupos das progênies e das testemunhas no ambiente de outono (PU, Tabela 24), quando estimada com base na média de todos os ambientes (Geral), a correlação entre o acamamento (AC) e o valor agronômico (VA) foi positiva, com valores para o grupos das progênies e das testemunhas de 42,24 e 33,65\%, respectivamente;), valores estes positivos para a geração $F_{9: 4}$, discordando do obtido em $F_{3: 2}$ por Pacova (1992), talvez devido à diminuição da diferença entre os maiores e menores valores de médias para o valor agronômico (Tabelas 14 e 16), valores estes que concordam com o obtido por médias de parcelas em $F_{5: 4}$ por Yokomizo (1994).

Para as estimativas de correlações entre $\mathrm{AC}$ e os caracteres NDM, APM, e PG foram obtidas estimativas de correlações positivas e altas nos ambientes 
(PV, AV e PU); concordando com o obtido por Saka et al. (1996) que obteve correlações positivas de AC com PG; porém discordando para AC com PCS e LVV, onde foram obtidas estimativas negativas para as progênies $F_{9: 4}$.

Entre VA e NDM foi estimada correlação igual a $-70,92 \%$ para as testemunhas no ambiente de outono (PU); enquanto que nos ambientes de verão ( $\mathrm{PV}$ e AV) para o grupo das progênies em todos os três ambientes as estimativas foram positivas. Com ciclos maiores (NDM) as plantas crescem mais e, dessa foram, recebem notas maiores de VA, com isso a correlação entre VA e NDM é positiva. Correlações positivas entre VA e NDM também foram obtidas para as progênies da geração $F_{5: 4}$ (Yokomizo, 1994). Todavia, nas condições de outono (PU) o VA e o NDM apresentaram médias das progênies para cada caráter próximas e, com isso, ocorreu alteração na correlação que passou a ser baixa, reflexo da covariância estimada entre os caracteres para o cálculo da correlação ter sido baixa.

Entre VA e LVV para o grupo das testemunhas a estimativa geral de correlação foi positiva $(52,47 \%)$, diferindo das demais correlações significativas que foram negativas, estas correlações negativas foram semelhantes às correlações obtidas em $F_{5: 4}$ (Yokomizo, 1994).

Para as correlações de VA com APM e PG, os valores obtidos de correlações foram positivos e altos, com exceção da correlação VA com PG para o grupo das testemunhas no ambiente favorável (PV), cuja estimativa de correlação foi negativa e média.

Entre NDM e APM as correlações foram positivas e de médias a altas (Tabela 24), com exceção para o grupo das testemunhas no ambiente de outono (PU) cuja estimativa foi $-51,16 \%$, este valor de correlação é discrepante caso se considere que quanto maior o ciclo (NDM) maiores serão as condições para a planta crescer (p.ex. em APM); relativamente, valores positivos para esta correlação foram obtidos por vários autores (Santos et al., 1995; Yokomizo, 1994; Shukla \& Pushpendra, 1998), apesar que Moro et al. (1992) também obteve valor negativo em um dos cruzamentos avaliados e positivo nos demais. A estimativa obtida para a correlação entre NDM e APM para o grupo das testemunhas no ambiente PU foi reflexo da estimativa baixa de covariância 
entre os caracteres, além da possibilidade dos cultivares empregados como testemunhas terem ramificado mais nesta condição e com isso terem menor APM.

Nos ambientes PU e AV para o grupo das testemunhas as correlações entre NDM e LVV foram estimadas respectivamente em 62,79 e $63,72 \%$; estes resultados diferem do obtido em $F_{5: 4}(r=-0,16$ a $-0,48)$ por Yokomizo (1994); uma provável explicação para as correlações altas obtidas em $\mathrm{F}_{9: 4}$ é dada pela variabilidade relativamente baixa (denominador) dos caracteres no cálculo de correlação, conforme é apresentado na Tabela 27, onde as diferenças entre as médias de testemunhas para LVV foi igual a 0,08 (PU) e 0,09 (AV); e para NDM de 8 dias (PU e AV).

A comparação entre as estimativas significativas obtidas para a correlação entre NDM e PCS (Tabela 24) nos dois grupos, com valores positivos para o grupo das testemunhas e correlações negativas para o grupo das progênies; pode ser explicada pelas menores diferenças entre as médias das testemunhas em todas as condições ambientais(Tabela 27), com isso, os valores de correlações para o grupo de progênies variou de $-25,49$ a $-66,91$ e de 45,22 a 89,19 no grupo das; Santos et al. (1995) obteve estimativas positivas de correlação entre NDM e PCS, já Yokomizo (1994) e Shukla \& Pushpendra (1998) encontraram estimativas negativas.

$\mathrm{Na}$ Tabela 24 a correlação entre NDM e PG para o grupo das testemunhas foi alta e negativa (-62,80\%), no ambiente estressante de outono (PU), esta estimativa difere dos valores positivos encontrados por outros autores (Weber \& Moorthy, 1952; Johnson et al., 1995; Anand \& Torrie, 1963; Kwon \& Torrie, 1964; Byth et al., 1969; Harrison et al., 1981; Moro et al., 1992; Pacova, 1992; Yokomizo, 1994; Santos et al., 1995; Shukla \& Pushpendra, 1998); podendo-se explicar pelas médias baixas de PG obtidas nas condições de outono (PU) para as testemunhas e também pelas condições especiais do cultivo na forma de covas de plantas individuais.

$\mathrm{Na}$ Tabela 24 para o grupo das testemunhas baseada na média do ambiente favorável (PV) e na média dos três ambientes em conjunto, obteve-se respectivamente as correlações de 42,77 e $38,05 \%$ entre APM e PCS, correlações concordantes com Santos et al. (1995) e diferente dos valores negativos $(-3,58$ a $-56,84 \%$ ) observadas para o grupo das progênies (em PV, PU, AV e geral) e para o 
grupo das testemunhas (em PU e AV); valores negativos que concordam com os obtidos por Konovsky et al. (1996) e Shukla \& Pushpendra (1998). Por outro lado Saka et al. (1996) não obtiveram correlação significativa entre APM e PCS. A correlação positiva entre os caracteres APM e PCS para o grupo das testemunhas (Tabela 24), a partir das médias dos três ambientes (Geral) também pode ter sido influenciada pela testemunha Nimame, com média menor de APM relação as outras três testemunhas e, menor tamanho das sementes (PCS). Aparentemente, não existem explicações para uma correlação significativa entre APM e PCS. Os próprios resultados obtidos por diferentes autores, ora positivos e ora negativos, ilustram a possivel independência de controles genéticos desses dois caracteres.

Entre PCS e PG foram observados valores positivos de correlação para as testemunhas (86,42\% em PV e 61,07\% na Geral, Tabela 24). Neste caso, são esperados valores negativos conforme observado por Yokomizo (1994) e Saka et al. (1996). Todavia, Santos et al. (1995) e Shukla \& Pushpendra (1998) também obtiveram valores positivos de correlações; certamente isto está associado ao fato das testemunhas mais produtivas também terem sementes maiores (Tabela 13); deve-se ressaltar que este comportamento é específico para o conjunto de testemunhas empregadas, já previamente selecionadas para maiores médias de PG e PCS.

\subsubsection{Para as progênies individuais}

$\mathrm{Na}$ Tabela 25 são apresentadas as correlações fenotípicas de Pearson entre os caracteres avaliados para cada progênie nos três ambientes em conjunto. Entre AC e VA para as progênies 2 e 16 as correlações foram significativas e iguais a 85,70\% e $88,17 \%$, respectivamente, as demais progênies não apresentaram valores significativos de correlação. Valores negativos de correlações entre AC e VA são esperados, como aqueles obtidos em $F_{3: 2}$ por Pacova (1992) e em $F_{5: 4}$ por Yokomizo (1994), uma possível explicação para as correlações positivas obtidas é dada pelas médias baixas para AC e VA nas progênies 2 e 16 (Tabela 16), causando alteração na estimativa das correlações.

Geralmente, plantas com maior ciclo (NDM) crescem mais em altura (APM) e, com isso, apresentam tendência de maior AC. Portanto correlações entre AC e 
NDM comumente são positivas, conforme observado em $F_{5: 4}$ por Yokomizo (1994), porém as progênies $(5,6$ e 7 ; Tabela 25$)$ da geração $F_{9: 4}$ apresentaram correlações próximas de $-80 \%$, ou seja com tendência de maior $\mathrm{NDM}$ e menor $\mathrm{AC}$. $\mathrm{O}$ comportamento da progênie 5 pode ser explicado pela média baixa de AC $(1,44$; Tabela 16) combinado com média baixa de APM (31 cm; Tabela 16); a progênie 6 apresentou APM maior, aliás bem maior que as APM das demais progênies, causando inversão no comportamento da correlação entre $\mathrm{AC}$ e NDM. Já para a progênie 7 a correlação negativa entre AC e NDM pode ser explicada pelo ciclo muito precoce (108 dias, Tabela 16) e pela média baixa de APM $(34,9 \mathrm{~cm}$, da Tabela 16$)$ produzindo uma covariância negativa entre os caracteres.

A correlação entre AC e PCS foi positiva e significativa (89,47\%) para a progênie 18 (Tabela 25), talvez devido às pequenas diferenças observadas entre as médias e aos baixos desvio padrões dos caracteres (Tabela 16), concordando com a correlação positiva estimada por Saka et al. (1995), porém Yokomizo (1994) observou valores negativos de correlação entre AC e PCS na geração $F_{5: 4}$, semelhante ao obtido para a progênie 1 com correlação negativa e significativa $(-93,80 \%)$. As demais progênies não apresentaram correlações significativas entre AC e PCS.

As plantas com maior tamanho das sementes (PCS) apresentam menor número de vagens, recebendo menor nota de VA; refletindo numa correlação negativa entre PCS e VA, conforme observado na geração $F_{9: 4}$ para as progênies $4(-92,15 \%)$ e 10 $(-83,62 \%)$, que concordam com o obtido em $F_{3: 2}$ por Pacova (1992) e em $F_{5: 4}$ (Yokomizo, 1994). Todavia, a progênie 6 apresentou correlação de 88,11\% (Tabela 25), podendo ser explicada pela diferença pequena entre as médias de VA e também de PCS, cujos desvios padrões foram 0,103 e 0,967 , respectivamente. As demais progênies não apresentaram correlações significativas entre VA e PCS.

Geralmente plantas com maior NDM também apresentam maior APM; com isso são esperados valores positivos de correlações entre NDM e APM, conforme observado em progênies $F_{3: 2}$ por Pacova (1992), em $F_{5: 4}$ por Yokomizo (1994) e em linhagens por Shukla \& Pushpendra (1998). Já Moro et al. (1992) obteve valor negativo num único cruzamento avaliado. A progênie 5 (Tabela 25) apresentou correlação de 
$-85,45 \%$; possivelmente devido às pequenas diferenças entre as médias de NDM e entre as de APM, reduzindo as variâncias dos dois caracteres e o denominador da fórmula de correlação. Correlações positivas e significativas maiores que $82 \%$ foram obtidas para as progênies $4,9,12,17,19,20,21 \mathrm{e} \mathrm{23}$, as demais progênies não apresentaram correlações significativas entre os caracteres NDM e APM.

$\mathrm{Na}$ Tabela 25, as progênies 4 e 9 apresentaram correlações negativas e significativas entre NDM e PCS, respectivamente $-97,40$ e $-83,34 \%$; para a progênie 1 ocorreu uma particularidade, pois a correlação estimada foi de $83,65 \%$ entre os caracteres NDM e PCS. As demais progênies não apresentaram correlações significativas. Santos et al. (1995) obteve correlação positiva entre NDM e PCS; contrariamente, Yokomizo (1994) e Shukla \& Pushpendra (1998) obtiveram estimativas negativas; já para Johnson et al. (1955), Kwon \& Torrie (1964) e Pacova (1992) as estimativas foram baixas e positivas.

A correlação entre os caracteres APM e LVV (Tabela 25) foi negativa e significativa para as progênies $6,17,20$ e 24 , respectivamente $-81,66 \%,-92,62 \%$, $-82,16 \%$ e -83,46\%; concordando com as correlações obtidas em $F_{3: 2}$ por Pacova (1992) e em $F_{5: 4}$ por Yokomizo (1994); pois plantas com maior APM tem maior PG, e tendem a ter menor tamanho das sementes (PCS). Uma correlação positiva e significativa $(84,68 \%)$ foi obtida para a progênie 16 , diferindo das demais progênies; que foram negativas e significativas ou não foram significativas.

A largura visual das vagens (LVV) é associada diretamente com o tamanho de sementes (PCS); deste modo, são esperadas correlações positivas entre eles; concordando com Frank \& Fehr (1981), Fraser et al. (1982), Shanmugasundaran \& Chung-Ruey (1982), Pacova (1992), Yokomizo (1994) e Saka et al. (1996). Duas progênies (15 e 17) apresentaram correlações entre LVV e PCS negativas e significativas (-91,54\% e - $85,22 \%$, respectivamente) (Tabela 25$)$, que pode ser explicada pela pequena diferença dos desvios padrões $(0,05)$ de LVV. As demais 23 progênies não apresentaram correlações significativas.

As plantas com maior peso de cem sementes (PCS) e maior largura das vagens (LVV), em geral tem menor produtividade (PG). A progênie 4 apresentou 
correlação entre PCS e PG de -90,73\% (Tabela 25). As progênies $10,15,17$ e 22, apresentaram estimativas de correlações entre LVV e PG variando de $-87,52 \%$ a $-96,25 \%$; concordando com o obtido em $F_{5: 4}$ por Yokomizo (1994). Já as progênies 6, 16 e 17 apresentaram correlações entre PCS e PG maiores que $84 \%$, concordando com as correlações obtidas por Santos et al. (1995) e Shukla \& Pushpendra (1998); porém maiores que o obtido por Johnson et al. (1995). As demais progênies não apresentaram correlações significativas entre PCS e LVV com PG.

\subsection{Correlações genéticas}

$\mathrm{Na}$ Tabela 26 são apresentadas as estimativas das correlações genéticas para o grupo das progênies em cada ambiente individualmente (PV, PU e AV) e para os três ambientes em conjunto (Geral).

Nos ambientes Piracicaba-outono (PU), Anhembi-verão (AV) e conjunta (Geral), as estimativas de correlações entre AC e VA, foram respectivamente $61,79 \%, 66,80 \%$ e $58,46 \%$ (Tabela 26); resultados contrários aos obtidos para as correlações fenotípicas em $F_{3: 2}$ por Pacova (1992) e em $F_{5: 4}$ por Yokomizo (1994). A explicação para as correlações positivas entre $\mathrm{AC}$ e VA pode ser devido a pequena diferença entre as médias de VA e de AC (Tabela 28), causando alterações nas estimativas de correlações que pode ocorrer segundo Gomez \& Gomez (1984).

$\mathrm{Na}$ Tabela 26, as estimativas das correlações genéticas entre $\mathrm{AC}$ e NDM foram semelhantes (entre $41,07 \%$ e $54,66 \%$ ) para os ambientes de verão (PV, AV) e a Geral. Já no ambiente de outono (PU), a correlação foi baixa $(5,87 \%)$, explicado pela pequena diferença entre as médias de NDM nas condições estressantes. As correlações indicaram a tendência de progênies com maior ciclo (NDM) terem tendência de acamarem mais.

As correlações genéticas entre AC e APM foram positivas e altas (em torno de 90\%)nos ambientes PU, AV e Geral (Tabela 26). Fato este, indicativo de que progênies com maior APM tenderam a maior $\mathrm{AC}$. No ambiente de verão (PV) a estimativa foi $60,32 \%$, explicado pela menor variação entre as médias das progênies para AC no ambiente $\mathrm{PV}$. 
Entre os caracteres AC e LVV (Tabela 26), as correlações genéticas foram negativas, com o ambiente estressante de outono (PU) apresentando a maior correlação $(-82,91 \%)$. Comportamento indicativo da tendência de plantas com menor AC produzirem plantas com maior LVV, característica de interesse para a soja tipo alimento com sementes grandes. Para as correlações entre AC e PCS foram obtidas estimativas baixas e negativas $(-14,41$ a $-23,65)$, nos ambientes PU, AV e Geral, concordando com as estimativas obtidas por Leroy et al. (1991). No ambiente de verão (PV) a estimativa entre AC e PCS foi igual a 4,22; semelhante ao obtido por Kwon \& Torrie (1964), Johnson et al. (1955) e em $F_{3: 2}$ (Pacova, 1992).

As correlações genéticas, apresentadas na Tabela 26, entre AC e PG foram positivas; variando de 55,63\% no ambiente de verão (PV) a 97,89\% no ambiente de outono (PU); indicando que plantas com maior AC apresentaram maior PG, a explicação seria que, progênies com maior AC tiveram maior APM com reflexo na produtividade (PG), devido ao maior crescimento da planta.

$\mathrm{Na}$ Tabela 26, as correlações genéticas entre VA e NDM foram iguais a -34,50\% e -35,21\% nos ambientes PV e PU, respectivamente; sendo que as diferenças entre as médias para AC nos ambientes PV e PU foram baixos, 0,31 e 0,29, respectivamente, deste modo, os valores de correlação entre VA e NDM obtidas de diferenças de médias maiores $(\mathrm{AC})$ entre as progênies são mais consistentes, como as obtidas no ambiente AV $(59,26 \%$ ) e na conjunta (Geral, 63,66\%); concordando com o obtido em $F_{3: 2}$ (Pacova, 1992).As correlações positivas entre VA e NDM indicam que progênies com ciclo maior, receberam notas maiores de VA, por apresentarem maior produtividade de grãos (PG) e altura de planta na maturidade (APM).

Entre VA e APM as estimativas de correlações genéticas foram altas e positivas nos ambientes PU, AV e na Geral (Tabela 26), com correlações iguais a $73,54 \%, 81,76 \%$ e $77,82 \%$, respectivamente; devido as plantas com maior APM receberem notas maiores de VA (Pacova, 1992). Já no ambiente favorável (PV) a correlação foi negativa $(-21,61 \%)$, devido as plantas terem crescido mais em PV do que nos outros ambientes, com notas maiores de $\mathrm{AC}$ e, refletindo em notas menores de VA (Figura 2, Tabelas 13, 14 e 16). 
As estimativas das correlações genéticas entre VA e LVV e entre VA e PCS foram negativas (Tabela 26), variando de -16,11 a -71,57\%; confirmando o obtido em $F_{3: 2}$ (Pacova, 1992). Comportamento esperado, pois plantas com maior PCS e LVV, apresentam menor número de vagens na haste e nas ramificações da planta e, com isso recebem nota menor de valor agronômico (VA).

$\mathrm{Na}$ Tabela 26, as correlações genéticas entre o VA e PG foram respectivamente, $>1,0097,52 \%$ e $>1,00$, nos ambientes $\mathrm{PU}, \mathrm{AV}$ e na Geral; comportamento semelhante ao obtido em $F_{3: 2}$ (Pacova, 1992); pois com maior produtividade (PG), as notas de VA para as plantas foram maiores. Já no ambiente PV a correlação genética foi igual a -19,81; devido ao maior APM das progênies no ambiente PV e maior AC, as notas de VA foram menores, produzindo a correlação negativa entre $\mathrm{VA}$ e PG.

Entre NDM e APM as estimativas de correlações genéticas foram altas e positivas, entre $70 \%$ a $80 \%$ nos ambientes PV, AV e Geral (Tabela 26), semelhante ao obtido em $F_{3: 2}$ (Pacova, 1992) e maiores do obtido por Moro et al. (1992), Santos et al. (1995) e Shukla \& Pushpendra (1998). Já no ambiente de outono (PU) a correlação foi igual a $-7,04 \%$, devido as menores diferenças entre as médias de NDM e de menor APM em relação aos outros ambientes.

Nos ambientes de verão (PV e AV), no ambiente estressante de outono (PU) e na conjunta (Geral), as correlações entre NDM e LVV foram negativas, de -1,04 a -91,32 (Tabela 26). Isto significa a tendência de progênies precoces apresentaram vagens mais largas. Na correlação entre NDM e PCS foi estimado valor igual a 52,62\%, no ambiente de outono (PU), correlação esta discordante de Pacova (1992), Shukla \& Pushpendra (1998); porém concordando com Santos et al. (1995), nos demais ambientes foram obtidas estimativas de correlações variando de $-44,64 \%$ a $-75,85 \%$.

As estimativas das correlações genéticas entre NDM e PG foram positivas e entre $25,43 \%$ e $87,16 \%$ (Tabela 26 ) para os três ambientes (PV, PU e AV) e na conjunta (Geral); estas estimativas foram maiores do que as obtidas por Moro et al. (1992) e Shukla \& Pushpendra (1998), a estimativa de $87,16 \%$ no ambiente PV foi semelhante ao obtido em $F_{3: 2}$ por Pacova (1992) e Santos et al. (1995). Comportamento 
similar de correlação genética de NDM com PG foi observada entre APM e PG, com valores entre 55,02\% e 88,70\%, concordando com Moro et al. (1992) e Santos et al. (1995).

As correlações genéticas entre APM e LVV ou PCS foram negativas $(-0,64$ a $-73,65 \%)$, para os três ambientes (PV, PU e AV) e na conjunta (Geral); comportamento semelhante ao obtido em $F_{3: 2}$ por Pacova (1992) e Shukla \& Pushpendra (1998) e diferindo de Santos et al. (1995) com estimativas positivas entre APM e PCS.

Correlações genéticas entre LVV e PCS foram positivas, e respectivamente iguais a $83,84 \%, 62,99 \%$ e $64,96 \%$ para os ambientes $\mathrm{PV}, \mathrm{AV}$ e a Geral (Tabela 26), concordando com $F_{3: 2}$ (Pacova, 1992) e com estimativas de correlações fenotípicas em $\mathrm{F}_{5: 4}$ (Yokomizo, 1994). No ambiente de outono (PU) a correlação entre LVV e PCS foi igual a $-13,15 \%$, com possibilidade de ter ocorrido falha na granação nas condições de outono.

$\mathrm{Na}$ Tabela 26, as correlações entre PG e LVV ou PCS, foram negativas, variando de $-35,79$ a $-84,80 \%$ nos ambientes PV, AV e na conjunta (Geral), concordando com $F_{3: 2}$ (Pacova, 1992), pois espera-se que com maior PG, haverá diminuição no tamanho das sementes (PCS e da largura das vagens (LVV), porém esta correlação é indefinida, com estimativas de $-60 \%$ a $66 \%$ na literatura (Johnson et al., 1955; Anand \& Torrie, 1963; Kwon \& Torrie, 1964; Burris et al., 1973; Harrison et al., 1981; Santos, 1988; Santos et al., 1995 e Shukla \& Pushpendra, 1998). No ambiente de outono (PU) para a correlação entre PCS e PG a estimativa foi igual a $31,31 \%$, devido a diminuição da produtividade de grãos (PG) nas condições de outono (Figura 1, Tabela 13, Tabela 14 e 15).

\subsection{Avaliação da interação $G$ x E pela ecovalência e pelo histograma}

As Tabelas 27 e 28 apresentam as estimativas de interação $G \times$ E obtidas pelo método da ecovalência proposto por Wricke (1965). Tais resultados devem ser considerados como preliminares, pois a classificação pode se alterar de ano para ano (Hühn \& Léon, 1985; Rognli, 1987), recomendando-se três a quatro anos de resultados para uma análise precisa (Wricke, 1965). Também deve-se ressaltar que a comparação 
com outros resultados ficou limitada a um único trabalho (Yue et al., 1997) sobre ecovalência para produtividade de grãos (PG) em soja; os demais trabalhos encontrados na literatura envolveram outras espécies: Sorghum bicolor (L.) Moench (Jowett, 1972); Festuca arundinacea Schreb (Nguyen et al., 1980); Dactylis glomerata L. (Gray, 1982); Saccharum officinarum (Galvez, 1980; Kang \& Miller, 1984; Raizer, 1998) e com Phaseolus vulgaris (Duarte \& Zimmermann, 1995).

Para a soja alimento com sementes grandes é importante analisar os caracteres relacionados ao tamanho das sementes: Largura Visual das Vagens (LVV) e Peso de Cem Sementes (PCS). Na Tabela 29, percebe-se que somente ocorreu coincidência perfeita para os destaques entre as progênies 2 e 16, incluídas no grupo das menos estáveis. No total, entre os destaques positivos e negativos, 15 das 24 progênies avaliadas manifestaram tendências semelhantes para os caracteres LVV e PCS. Como materiais menos estáveis para LVV tem-se as progênies $1,2,7$ e 16, com estimativas altas de ecovalência, entre 8,21 e 19,78\%; estas quatro progênies sozinhas são responsáveis por mais de $50 \%$ da ecovalência total. Os genótipos mais estáveis foram as progênies $4,5,13,15,18$ e 21 , com valores baixos, entre $0,03 \%$ e $0,33 \%$; além dessas seis progênies existem outras que também apresentam valores baixos a intermediários de ecovalência. As testemunhas (Tabela 29) podem ser consideradas estáveis para o caráter LVV, com médias de ecovalência entre $0,23 \%$ e $2,17 \%$.

Analisando-se as estimativas obtidas para valor agronômico (VA, Tabela 29) tem-se que as maiores ecovalências $(6,5 \%$ à $15,0 \%)$ foram apresentadas pelas progênies $10,11,16,17$ e 22; estas últimas são as progênies menos estáveis e, portanto, as maiores responsáveis pelo efeito da interação genótipos $\mathrm{x}$ ambientes. Como genótipos mais estáveis destacaram-se as progênies $4,7,12$ e 23, com valores entre 0,2 e 0,6; tais valores podem ser considerados despreziveis, em comparação com a média estimada entre as quatro testemunhas $(2,0)$; além destas quatro, outras cinco progênies $(1,2,6,8$, e 20) com médias abaixo de 2,0 de ecovalência para VA, também podem ser consideradas como estáveis.

Para o caráter acamamento (AC, Tabela 29) pode-se considerar que oito progênies apresentaram comportamento de baixa estabilidade, com valores altos de 
ecovalência entre $5 \%$ e $10 \%$, perfazendo mais de $50 \%$ de toda a ecovalência, ou seja, da interação genótipo $\times$ ambiente e muito acima da média $(3,6 \%)$ entre as quatro testemunhas. Três testemunhas (Céu Azul, Tamba e Nimame) podem ser consideradas estáveis para $\mathrm{AC}$, pois apresentaram valores baixos de ecovalência $(1,0$ a $1,5 \%)$; no entanto, a testemunha IAC PL-1 mostrou-se instável, com 10,7\% de ecovalência para AC. As progênies 7 e 19 alcançaram os maiores valores (cerca de 10\%) de ecovalência e, portanto, foram as de menor estabilidade. Dentre as 24 progênies, 14 tiveram valores de ecovalência inferiores à média $(3,6 \%)$ das testemunhas; destacaram-se as progênies 8 , 13,15 e 17 com valores de ecovalência inferiores àquele $(1,098 \%)$ da testemunha Tamba mais estável.

Para o ciclo da planta (NDM, Tabela 29), cinco progênies $(5,10,11$, 17 e 19) apresentaram alta instabilidade, com estimativas entre 9,51\% e 14,45\%, perfazendo juntas quase $60 \%$ de toda a ecovalência existente; tais progênies apresentaram alterações de comportamento proporcionais às mudanças ambientais, ou seja, tornaram-se mais precoces no outono e mais tardias no verão. Cinco progênies $(6$, $9,13,20$ e 21 ) apresentaram valores baixos de ecovalência, entre $0,36 \%$ e $0,91 \%$, sendo as mais estáveis em NDM para as condições dos experimentos; a ecovalência média das testemunhas foi $0,52 \%$, um valor que pode ser considerado baixo e indicativo da estabilidade relativa existente em cultivares de soja alimento.

Para a altura da planta na maturidade (APM, Tabela 29), as progênies 11 e 17 , com ecovalências respectivamente de $20,07 \%$ e $13,97 \%$ foram as de menor estabilidade, sendo seguidas pelas progênies 3, 18 e 19; estas cinco progênies juntas responderam por mais de $50 \%$ da ecovalência total. As mais estáveis foram as progênies $4,5,15,20,21,22$ e 24 , com ecovalências variando de $0,91 \%$ a $0,01 \%$. Três testemunhas (IAC PL-1, Tamba e Nimame) apresentaram médias de ecovalência acima de $4,00 \%$ e, portanto, não podem ser consideradas estáveis; desta maneira, as comparações das progênies com as testemunhas devem ser feitas criteriosamente. Observa-se uma concentração da ecovalência em torno de algumas progênies, pois existem 16 progênies relativamente estáveis, três intermediárias e as cinco restantes 
com baixa estabilidade; estas últimas são as principais responsáveis pela maior contribuição à interação genótipo $\mathrm{x}$ ambientes para APM.

Na Tabela 29, para o caráter produtividade de grãos (PG), observa-se que as menores estabilidades foram apresentadas pelas progênies $2,9,11,13$ e 24 , com valores de ecovalência entre $7,54 \%$ e $9,50 \%$. Uma observação importante é que os materiais mais instáveis para PG tiveram médias próximas entre si; para os demais caracteres avaliados as progênies instáveis apresentaram médias mais distintas em relação às estáveis. Três das testemunhas (IAC PL-1, Tamba e Nimame) apresentaram valores elevados de ecovalência, ou seja, entre 5,28\% e 6,99\%; estas testemunhas apresentaram comportamento sensível para PG em relação a qualquer alteração ambiental, possivelmente devido ao fato de terem sido selecionadas para caracteres apropriados à soja alimento.

Para o caráter tamanho de sementes (PCS, Tabela 29), as mais estáveis foram as progênies $3,6,8,19$ e 23 com ecovalências entre $0,28 \%$ e $0,59 \%$; as progênies menos estáveis foram as $2,10,11$ e 16 , com ecovalências entre $7,29 \%$ e $17,02 \%$; sete progênies foram as principais responsáveis, com mais de $50 \%$ da ecovalência total, pela interação genótipos $\mathrm{x}$ ambientes. É conveniente ressaltar que mesmo existindo efeitos de interação a amplitude de variação de ecovalência para PCS é menor do que em outros caracteres (Figura 1 e Tabelas 13, 14 e 15).

No único trabalho (Yue et al., 1997) encontrado na literatura sobre teste de ecovalência para produtividade de grãos em soja, a amplitude observada no trabalho foi menor do que aquela encontrada para as progênies $F_{9: 4}$. Provavelmente, os genótipos das duas pesquisas são geneticamente muito distintos, de maneira a se justificar as diferenças encontradas.

Pela Tabela 30, tomando-se como referência a testemunha IAC PL-1, com o maior valor $(5,05 \%)$ de ecovalência, pode-se considerar este valor como sendo o limite máximo para classificar um genótipo como estável, relativamente ao conjunto de caracteres avaliados. A testemunha IAC PL-1 também apresentou o maior desvio $(3,53)$ de ecovalência entre os caracteres avaliados para o grupo das testemunhas. Quatro progênies $(10,11,17$ e 19) podem ser consideradas de baixa estabilidade, com médias 
entre 6,39\% e 10,74\%; estas progênies também apresentaram valores altos de desvios, fato este que vem reforçar a classificação anterior destas progênies como sendo as menos estáveis entre os materiais testados, considerando-se todos os caracteres conjuntamente. Entre as progênies com médias intermediárias de ecovalência, entre 3,00 e 4,99, existem materiais com elevada variância; tal fato indica que existe um ou mais caracteres que apresentam maior interação $\mathrm{G} \times \mathrm{E}$ em relação aos outros; neste caso, cada caráter deve ser considerado individualmente na análise da estabilidade; como exemplos podem ser citadas as progênies 1,7 e 16 cujos desvios foram respectivamente $6,93 \%$, $5,29 \%$ e $4,17 \%$, inclusive superando algumas progênies que apresentaram as maiores médias de ecovalência. Destacaram-se as progênies $4,6,8,12,14,21$ e 23, que além de médias baixas (abaixo de 3,00\%) de ecovalência, também exibiram os menores desvios (abaixo de 1,90\%), podendo, assim, serem classificadas como sendo as progênies mais estáveis para todos os caracteres avaliados.

De acordo com Vega (1984) e com Duarte \& Zimmermann (1995), a independência entre a produtividade e a ecovalência causa a necessidade do uso simultâneo dos dois parâmetros para a seleção de genótipos de com alta produtividade $\mathrm{e}$ estáveis. Portanto, há necessidade de se associar médias e desvios baixos de ecovalência (maior estabilidade) com desempenhos positivos para os caracteres PG e PCS.

$\mathrm{Na}$ Tabela 30, tomando-se como referência a média das quatro testemunhas como limite máximo de ecovalência $\left(\mathrm{M}_{\mathrm{eco} \%}=2,86\right.$ e desvio $\left.=2,52\right)$, abaixo da qual se pode considerar uma progênie como estável para o conjunto de caracteres avaliados, obtêm-se 11 progênies ( $46 \%$ de 24 ) classificadas como estáveis: $3,4,6,8,12$, $14,15,18,20,21$ e 23 . A progênie 21 foi a mais estável de todas, com ecovalência $\left(\mathrm{M}_{\mathrm{eco} \%}\right.$ e $\left.\mathrm{S}_{\mathrm{eco} \%}\right)$ equivalente à da testemunha 'Céu Azul'. Considerando que o método da ecovalência pode não ser muito preciso quando aplicado a um conjunto de apenas três ambientes, como ocorre nesta pesquisa, torna-se recomendável relaxar a intensidade de seleção das progênies, através da utilização de um referencial menos rigoroso, o qual pode ser por exemplo a ecovalência $\left(M_{\mathrm{eco} \%}=5\right.$ e $\left.\mathrm{S}_{\mathrm{eco} \%}=3,46\right)$ do cultivar IAC PL-1 de soja alimento, a menos estável das testemunhas. De acordo com este último critério de seleção mais branda, 17 progênies ( $71 \%$ de 24$)$ seriam classificadas como estáveis: 2,3 , 
$4,5,6,8,9,12,13,14,15,18,20,21,22,23$ e 24 . Além da estabilidade, devem ser considerados critérios adicionais de seleção, envolvendo principalmente os caracteres da Tabela 30 .

Acrescentando-se como critérios gerais retirados da Tabela 30:

- PCS mínimo de $17,8 \mathrm{~g}$ (testemunha Nimame);

- PG mínimo de 46,5g (testemunha Nimame);

- $\mathrm{PG}_{\mathrm{t}} \% \geq 0$;

três progênies ( 2,5 e 15$)$ seriam descartadas por não apresentarem níveis adequados de PG. De fato, as progênies 2 e 5 produziram respectivamente 29,3 e $36,8 \mathrm{~g} / \mathrm{planta}$; já a progênie 15 , apresentou $\mathrm{PG}_{\mathrm{t}} \%=-15,85 \%$, abaixo da produtividade médias das testemunhas.

Em uma primeira seleção, para soja alimento tipo salada (seleção salada), os seguintes caracteres da Tabela 30 devem ser acrescentados:

- Cor do tegumento = amarelo;

- Cor do hilo = creme ou marrom.

A seleção salada resultaria nas seguintes cinco progênies selecionadas, a partir das Tabelas 1 e 30 :

\begin{tabular}{|c|c|c|c|c|c|c|c|}
\hline \multicolumn{8}{|c|}{ SELEÇÃO SALADA } \\
\hline $\begin{array}{l}\text { Prog } \\
\end{array}$ & ies selecionadas & & & \multirow[b]{2}{*}{ PCS } & \multirow[b]{2}{*}{ PG } & \multicolumn{2}{|c|}{ Cor } \\
\hline \multirow[t]{2}{*}{$\mathrm{N}^{\mathrm{O}}$} & \multirow[t]{2}{*}{ N USP } & \multicolumn{2}{|c|}{ Topocruzamentos } & & & Tegumento & Hilo \\
\hline & & & & gramas & g/planta & & \\
\hline 3 & $98-06007$ & $\left(\mathrm{KS} 473 \times \mathrm{SJ}_{2} \mathrm{~F}_{7}\right)$ & x Doko & 19,8 & 80,0 & Amarelo fosco & Preto/marrom \\
\hline 4 & $98-06009$ & $\mathrm{TMV}$ & x Doko & 19,3 & 56,1 & Amarelo fosco & Preto/marrom \\
\hline 20 & $98-06027$ & IAC PL-1 & $x$ FT-2 & 18,4 & 69,9 & Amarelo brilhante & Marrom \\
\hline 22 & $98-06029$ & Majos & x Doko & 18,1 & 102,0 & Amarelo fosco & Marrom \\
\hline 23 & $98-06031$ & PI 165.672 & x Doko & 21,1 & 59,0 & Amarelo fosco & Marrom \\
\hline
\end{tabular}

Dentre as cinco progênies selecionadas, quatro envolvem topocruzamentos com 'Doko' e apenas uma progênie envolveu o outro parental adaptado 'FT-2'. Portanto, houve uma predominância de topocruzamentos superiores envolvendo 'Doko', relativamente ao inicio do programa, quando a participação destes dois parentais 
foi idêntica, uma vez que todos os parentais exóticos foram topocruzados com 'Doko' e com 'FT-2'. Certamente, o maior sucesso do parental Doko tem muito a ver com a sua tolerância ao fotoperíodo (Hartwig \& Kiihl, 1979; Hinson, 1989; Kiihl \& Garcia, 1989).

Em relação à manutenção de diversidade genética, é importante observar que todas as cinco progênies selecionadas descendem de diferentes parentais de soja alimento. Mais detalhes sobre as genealogias das progênies encontram-se na Tabela 1.

Para uso como soja alimento tipo salada, as progênies selecionadas de $\mathrm{n}^{0} 3$ e 4, ainda precisam passar por uma seleção adicional em favor daquelas plantas que produzem sementes com hilo marrom, fenótipo este mais apropriado que o hilo preto. A progênie 22 foi o maior destaque por apresentar alta estabilidade, fenótipos favoráveis para os caracteres da soja alimento tipo salada e máxima produtividade de grãos $(102,0 \mathrm{~g} /$ planta $)$.

Em uma segunda seleção, para soja alimento tipo doce (seleção doce), as plantas devem produzir sementes maduras grandes, com tegumento e hilo de cor preta (Kuromame). Esta seleção doce resultaria em um segundo grupo de cinco progênies selecionadas, a partir das Tabelas 1 e 30:

\begin{tabular}{|c|c|c|c|c|c|c|}
\hline \multicolumn{7}{|c|}{ SELEÇÃO DOCE (KUROMAME) } \\
\hline \multicolumn{2}{|c|}{ Progenties promissoras } & \multirow[b]{2}{*}{ Topocruzamentos } & \multirow[b]{2}{*}{ PCS } & \multirow[b]{2}{*}{ PG } & \multicolumn{2}{|c|}{ Cor } \\
\hline $\mathrm{N}^{\mathbf{Q}}$ & N USP & & & & Tegumento & Hilo \\
\hline & & & gramas & g/planta & & \\
\hline 8 & USP 98-06013 & Late Giant $\times$ Doko & 20,7 & 74,2 & Preto fosco & Preto \\
\hline 9 & USP 98-06014 & Late Giant $x$ Doko & 20,1 & 92,4 & Preto fosco & Preto \\
\hline 12 & USP 98-06017 & Late Giant $\mathrm{x}$ Doko & 26,0 & 93,1 & Preto fosco & Preto \\
\hline 13 & USP 98-06018 & Late Giant $\mathrm{x}$ Doko & 20,7 & 101,4 & Preto brilhante & Preto \\
\hline 18 & USP 98-06025 & Aliança Preta x Doko & 20,1 & 78,7 & Preto fosco & Preto \\
\hline
\end{tabular}

Deve-se considerar que a cor escura do tegumento está associada com maior tolerância a estresses (Starzing et al., 1982; Mugnisjah et al., 1987; Li et al., 1990) e resistência a doenças (Ma et al., 1991). Portanto, as cinco progênies $(8,9,12,13$ e 18) selecionadas como tipo doce (kuromame) têm uma possível vantagem adicional para 
fortalecer a recomendação delas para cultivo. Esta associação entre tegumento de cor preta e maior tolerância a estresses, possivelmente é uma explicação para o alto nível de produtividade ( $\mathrm{PG}=74,2$ a $101,4 \mathrm{~g} /$ planta) apresentado por todas as cinco progênies selecionadas.

Contrariamente ao ocorrido na seleção salada, o grupo de progênies mantidas na seleção doce (kuromame) tem diversidade limitada, pois das cinco progênies selecionadas quatro são provenientes de um único topocruzamento (Late Giant x Doko). Certamente, estas quatro progênies herdaram a cor preta do tegumento do parental Late Giant. $\mathrm{O}$ maior destaque deste grupo corresponde à progênie 12 , com $\mathrm{o}$ valor máximo de tamanho de sementes $(\mathrm{PCS}=26,0 \mathrm{~g})$ e uma das maiores produtividades ( $\mathrm{PG}=93,1 \mathrm{~g} / \mathrm{planta})$ dentre todos os 28 genótipos avaliados.

Uma terceira seleção, agora para soja alimento tipo hortaliça (edamame, vagens imaturas largas, sementes grandes, sem restrição de cor de tegumento e de hilo), denominada seleção hortaliça, incluiria todas as dez progênies já selecionadas (seleção salada e seleção doce) e outras quatro progênies, caracterizadas a seguir, com base nos dados das Tabelas 1 e 30 :

\begin{tabular}{|c|c|c|c|c|c|c|c|}
\hline \multicolumn{8}{|c|}{ SELEÇÃO HORTALIÇA (EDAMAME) } \\
\hline \multicolumn{2}{|c|}{ Progênies promissoras } & \multirow{2}{*}{\multicolumn{2}{|c|}{ Topocruzamentos }} & \multirow[b]{2}{*}{ PCS } & \multirow[b]{2}{*}{ PG } & \multicolumn{2}{|c|}{ Cor } \\
\hline $\mathrm{N}^{\mathrm{o}}$ & N USP & & & & & Tegumento & Hilo \\
\hline & & & & gramas & g/planta & & \\
\hline 6 & USP 98-06011 & Araçatuba & x Doko & 23,4 & 71,7 & Amarelo fosco & Preto \\
\hline 14 & USP 98-06019 & Japão 1 & x Doko & 24,9 & 61,3 & Verde fosco & Preto \\
\hline 21 & USP 98-06028 & FC $31-665$ & x Doko & 21,4 & 55,3 & Amarelo fosco & Preto \\
\hline 24 & USP 98-06032 & Tadacha & x Doko & 19,7 & 92,4 & Marrom brilhante & Marrom \\
\hline
\end{tabular}

A seleção hortaliça (edamame) incluiu 14 progênies (58\% do total de 24), representando um resultado muito favorável. Destaque especial deve ser dado à progênie 21 , o genótipo mais estável (Tabela 30 ) dentre os 28 genótipos testados ( 24 progênies e quatro testemunhas); todavia, a progênie 21 apresentou a menor produtividade ( $\mathrm{PG}=55,3 \mathrm{~g} /$ planta) dentre o total de 14 progênies selecionadas, colocandose pouco abaixo $(\mathrm{PGt} \%=-4,45 \%)$ da média das testemunhas. 
Na Figura 1 tem-se os histogramas para os caracteres PG, PCS e VA; em relação ao teste de ecovalência (Tabela 29), pode-se observar que não houve coincidência entre os materiais mais estáveis, para PG e PCS, devendo-se tomar cuidados ao se empregar o histograma como um parâmetro de avaliação dos melhores desempenhos associado com maior estabilidade das progênies testadas. Comparando-se com a ecovalência (Tabela 29), as progênies $10,16,17$ e 22 consideradas como de baixa estabilidade apresentaram pelo histograma da Figura 1 um comportamento intermediário. É importante observar que as progênies mais estáveis pelo método da ecovalência (Tabela 29), no geral também podem ser consideradas estáveis pelo histograma da Figura 1; porém estas progênies $(4,7$ e 12) foram as de baixo desempenho pelo teste de Scott-Knott e então, não seriam interessantes, apesar de serem as mais estáveis. Deste modo, o emprego do histograma para associar os melhores desempenhos com as melhores estabilidades, não foi eficiente em comparação com o teste de Ecovalência.

\subsection{Interação $G$ x E pelo gráfico de caixa (Box Plot)}

O gráfico de caixa é um procedimento interessante para se comparar dados de dois ou mais grupos, colocando-os lado a lado (Montgomery 1991a, 1991b; Lane, 1998) e, com isso, observar o comportamento dos genótipos para os caracteres avaliados em cada ambiente. De acordo com Rose (1994), este gráfico permite a visualização da distribuição geral dos dados, sua média e sua mediana ( valor que divide a distribuição em duas metades de dados), permitindo a realização de inferências do efeito ambiental sobre os caracteres; portanto, representa um instrumento complementar ao estudo da interação genótipos $\mathrm{x}$ ambientes.

A Figura 2 mostra os resultados obtidos com o gráfico de caixa para os diferentes caracteres. $\mathrm{Na}$ interpretação deste gráfico, a caixa representa o intervalo de flutuação de $50 \%$ das médias das progênies; dentro da caixa, a linha tracejada corresponde à média geral de todas as progênies, enquanto que o sinal + corresponde à mediana. 
$\mathrm{O}$ ambiente favorável PV foi o que permitiu a expressão de uma maior diferença para a largura visual das vagens (LVV), com médias variando de 2,0 a 3,8, sendo que o comportamento médio foi concentrado em torno de 2,7. $\mathrm{O}$ ambiente de outono (PU) apresentou médias entre 2,0 e 3,4, sendo que a maioria das médias concentrou-se próximo de 3,0 . No ambiente $\mathrm{AV}$, as médias ficaram distribuídas de 2,0 a 3,0 , ou seja, apresentaram valores mais próximos entre si, com as maioria dos tratamentos com média em torno de 2,7. Nos três ambientes, a mediana situou-se abaixo da média geral, indicando maior concentração de dados de LVV abaixo da média geral.

Para o acamamento (AC), o ambiente PV apresentou as maiores médias, a maioria delas concentrando-se próximo de 4,0; as médias individuais das progênies variaram de 1,7 a 5,0. No ambiente de outono (PU) houve uma dispersão maior das médias, englobando a variação observada nos outros dois ambientes, com médias entre 1,0 e 4,7; estando a maioria delas em torno de 2,5 . No ambiente $A V$, as plantas apresentaram um menor acamamento em relação aos outros dois ambientes (PV e PU), com as médias variando de 1,0 a 4,0; as duas médias próximas de 4,0 foram consideradas discrepantes pela metodologia do gráfico de caixa; a maior parte das médias concentraram-se em torno de 2,0, representando baixo valor de acamamento. Para o caráter $\mathrm{AC}$, a posição relativa média/mediana variou entre os três ambientes e pode-se observar que no comportamento geral das progênies, o ambiente PV foi o que apresentou maior acamamento, o ambiente de outono (PU) foi intermediário e o ambiente AV foi o que apresentou menor acamamento.

Para valor agronômico (VA), no ambiente PV, as médias variaram de 1,7 a 2,7 , podendo-se observar uma média discrepante $(2,7)$ e uma média fora $(3,0)$; este último valor deve ser analisado em relação a possíveis problemas, como por exemplo erro na avaliação no campo; caso contrário, pode-se supor erroneamente que este valor indica uma progênie de comportamento muito superior em relação às demais. No outono (PU), as médias de VA variaram de 1,0 a 2,0, com a maioria delas próximas de 1,7; pode-se observar que o comportamento geral das médias foi pior no outono em relação aos outros dois ambientes de verão. O ambiente AV foi o que causou maior dispersão de 
médias de VA, com variação de 1,0 a 3,0, porém as médias tiveram uma tendência de se concentrarem próximas do obtido para o ambiente PV.

Ainda na Figura 2, para o número de dias para maturidade (NDM) pode-se observar que no ambiente Piracicaba-verão (PV) houve uma tendência das progênies comportarem-se de modo intermediário para o ciclo, em relação ao observado em Piracicaba-outono (PU) e Anhembi-verão (AV). Pelo gráfico de caixa pode-se observar que as médias de NDM em PV encontram-se entre 105 dias e 145 dias. No ambiente $\mathrm{AV}$, as plantas apresentaram comportamento geral mais tardio em relação aos outros dois ambientes, com médias concentradas entre 110 dias e 150 dias. No ambiente de outono (PU), uma única média situou-se na região de alerta (130 dias), mas isto não influenciou o comportamento geral das médias, que variaram entre 100 dias e 130 dias, com tendência geral das progênies serem mais precoces do que nos ambientes de verão (PV e AV).

Para altura da planta na maturidade (APM), no ambiente PV, as plantas apresentaram uma tendência de serem mais altas do que nos ambientes PU e AV, com a maioria das progênies concentradas em torno de 50 a $60 \mathrm{~cm}$; poucos valores de médias variaram fora deste intervalo, podendo alcançar mínimo de $35 \mathrm{~cm}$ e máximo de $90 \mathrm{~cm}$. No ambiente de outono (PU), as médias foram inferiores em relação aos outros dois ambientes, com tendência de se concentrarem próximas de $40 \mathrm{~cm}$; mas, existiram médias variando de 15 a $73 \mathrm{~cm}$. O ambiente AV apresentou comportamento intermediário entre PV e PU, com a maioria das médias próximas de $50 \mathrm{~cm}$ de $\mathrm{APM}$; observa-se ainda algumas médias variando de no mínimo $30 \mathrm{~cm}$ a no máximo $75 \mathrm{~cm}$. Um valor discrepante é observado no outono (PU), correspondente a uma progênie com APM acima de $70 \mathrm{~cm}$; porém, este valor não deve ter influenciado a média geral e mediana do gráfico de caixa.

Para a produtividade de grãos (PG, Figura 2), no ambiente PV ocorreu maior dispersão dos dados, com médias variando de $25 \mathrm{~g} /$ planta a mais de $175 \mathrm{~g} /$ planta; houve concentração das médias em torno de $100 \mathrm{~g}$ /planta, que representa um nível muito interessante de produtividade. As condições de outono (PU) causaram uma queda muito acentuada na produtividade (com valor máximo de $50 \mathrm{~g} /$ planta), em relação aos dois 
ambientes de verão (PV e AV). Isso indica que em geral as progênies e as testemunhas são muito sensíveis às condições de fotoperíodo, temperatura e umidade existentes; provavelmente, isto é devido ao controle poligênico da PG. No ambiente $\mathrm{AV}$, as médias obtidas foram menos dispersas em relação ao observado em PV, com distribuição de 25 a $130 \mathrm{~g} / \mathrm{planta}$; a maioria das médias ficou em torno de 70 $\mathrm{g} /$ planta, média esta menor que o obtido em PV, provavelmente devido ao tipo de solo existente em Anhembi, com problemas de fertilidade e de acidez.

Para o caráter peso de cem sementes (PCS, Figura 2) o ambiente PV apresentou as médias distribuídas de 12,5 a $30,0 \mathrm{~g}$; a maioria das progênies tiveram médias em torno de $21,5 \mathrm{~g}$, nível de PCS muito apropriado à soja alimento com sementes grandes. Para o ambiente PU, as médias ficaram mais próximas, variando de 15,0 a $25,0 \mathrm{~g}$, com a maior parte das progênies próximas de $20,0 \mathrm{~g}$; duas médias foram consideradas discrepantes, com valores muito baixos de PCS. No ambiente AV, as médias variaram de 16,0 até mais de $30 \mathrm{~g}$, porém a maioria das médias situaram-se próximas àquelas obtidas em $\mathrm{PV}$, ou seja, em torno de 21,5g. Pode-se observar na Figura 2 que a maioria das médias de PCS não se distanciaram muito entre os três ambientes; este fato indica que o caráter PCS é pouco influenciado pelo ambiente, em relação aos outros caracteres, ou então, há menos diferenças genéticas (talvez poucos genes envolvidos) a serem expressas em resposta às variações nas condições ambientais. 


\section{CONCLUSÕES}

Os resultados obtidos com genótipos de soja alimento com sementes grandes permitem as seguintes conclusões:

a) Várias das progênies superiores em $F_{9: 4}$ já haviam se destacado em gerações anteriores $\left(F_{2}, F_{3: 2}\right.$ ou $\left.F_{5: 4}\right)$.

b) Foram obtidas progênies precoces, com ciclo menor que 110 dias, mesmo em topocruzamentos com o parental tardio 'Doko'.

c) Ao se realizar seleção para maior altura da planta na maturidade (APM) é obrigatório considerar junto o acamamento (AC).

d) O ambiente favorável Piracicaba-verão foi o que melhor permitiu diferenciar as progênies para os caracteres APM, largura visual das vagens (LVV) e produtividade de grãos (PG). $\mathrm{O}$ ambiente estressante Piracicaba-outono permitiu a diferenciação das progênies para todos os caracteres, exceto para AC. $\mathrm{O}$ ambiente Anhembi-verão apresentou desempenho relativamente intermediário em discriminar as progênies.

e) As correlações entre caracteres foram muito alteradas pelas variações ambientais.

f) O gráfico de caixa evidenciou efeitos ambientais marcantes sobre os caracteres: valor agronômico (VA), número de dias para maturidade (NDM), PG e APM. Já o tamanho das sementes, avaliado pelo peso de cem sementes maduras (PCS) foi pouco influenciado pelas variações ambientais.

g) O método da ecovalência foi mais eficiente que o uso conjunto do teste de ScottKnott e de histograma para medir a estabilidade das progênies.

h) A seleção baseada na estabilidade medida pela ecovalência e nas médias dos caracteres relevantes para soja alimento com sementes grandes mostrou-se eficiente para obtenção de novos genótipos apropriados aos três tipos de usos: salada, doce, hortaliça. Para uso como salada, cinco progênies foram superiores: USP 98-06007, 
USP 98-0609, USP 98-06027, USP 98-06029 e USP 98-06031. Cinco progênies (USP 98-06013, USP 98-06014, USP 98-06017, USP 98-06018 e USP 98-06025) destacaram-se como soja alimento tipo doce. A seleção para soja alimento tipo hortaliça, além das dez progênies anteriores, incluiu mais quatro progênies (USP 9806011, USP 98-06019, USP 98-06028 e USP 98-06032). 


\section{REFERÊNCIAS BIBLIOGRÁFICAS}

AGRIANUAL 98. Anuário da Agricultura Brasileira. São Paulo: FNP Consultoria \& Comércio, 1998. p.355-388.

ALLARD, R. W. \& BRADSHAW, A. D. Implications of genotype- environmental interactions in applied plant breeding. Crop Science, v.4, p.503-508, 1964.

ANAND, S. C. \& TORRIE, J. H. Heritability of yield and other traits and interrelationships among traits in the $\mathrm{F}_{3}$ and $\mathrm{F}_{4}$ generations of three soybean crosses. Crop Science, v.3, n.6, p.508-511, 1963.

ARAI, S.; KOYANAGI, O.; FUJIMAKI, M. Studies on flavor components in soybean IV. Volatile neutral compounds. Agricultural and Biological Chemistry, v.31, m.7, p.868-873, 1967.

BARROS, E. G. de; MOREIRA, M. A.; FONTES, E. P. B. Atividades de Lipoxigenases $\mathrm{L}_{1}$ e $\mathrm{L}_{3}$ em cultivares comerciais de soja. Arquivo de Biologia e Tecnologia, v.27, n.3, p.381-386, 1984.

BEAVER, J. S. \& JOHNSON, R. R. Responses of determinate and indeterminate soybeans to varying cultural practices in the Northern USA. Agronomy Journal, v.73, p.833-888, 1981.

BERNARD, R. L. Two major genes for time of flowering and maturity in soybeans. Crop Science, v.11, p.242-244, 1971. 
BOARD, J. E. \& HALL, W. Premature flowering in soybean yield reductions at nonoptimal planting dates as influenced by temperature and photoperiod. Agronomy Journal, v.76, p.700-704, 1984.

BONATO, E. R. Herança do tempo para o florescimento e para a maturidade em variantes naturais de soja [Glycine $\max (\mathrm{L}$.) Merrill]. Piracicaba, 1989. 166 p. Tese (Doutorado) - Escola Superior de Agricultura "Luiz de Queiroz", Universidade de São Paulo.

BOOTE, K. J. Response of soybeans in different maturity groups to March plantings in Southern USA. Agronomy Journal, v.73, n.5, p.854-859, 1981.

BOQUET, D. J.; KOONCE, K. L.; WALKER, D. M. Selected determinate soybean cultivar yield responses to row spacings and plantings dates. Agronomy Journal, v.74, p.136-138, 1982.

BOWMAN, D.; RAYMER, P.; DOMBEK, D. Crop performance trials under irrigated and dryland conditions. Agronomy Journal, v.85, p.3, n.610-614, 1993.

BRAVO, J. A.; FEHR, W.R.; RODRIGUES DE CIANZIO, S. Use of pod width for indiret selection of seed weight in soybeans. Crop Science, v.20, p.507-510, 1980.

BRAVO, J. A.; FEHR, W.R.; RODRIGUES DE CIANZIO, S. Use of small-seeded soybean parents for the improvement of large seeded cultivars. Crop Science, v.21, p.430-432, 1981.

BRIM, C. A. Quantitative genetics and breeding. In: CALDWELL, B.E. (Ed.) Soybeans; improvement, production and uses. Madison, Wisconsin, American Society of Agronomy, 1973. cap. 5, p.155-186.

BRIM, C.A. \& COCKERHAM, C.C. Inheritance of quantitative characters in soybeans. Crop Science, v.1, p.187-190, 1961. 
BURRIS, J. S.; EDJE, O. T.; WAHAB, A. H. Effects of seed size on seedling performance in soybeans: II . Seedling growth and photosynthesis and field performance. Crop Science, v.13, p.207-210, 1973.

BURTON, J. W. Quantitative genetics: results relevant to soybean breeding. In: WILCOX, J. R. (Ed.) Soybeans: improvement, production and uses. 2.ed. Madison, American Society of Agronomy, 1987. cap.6, p. 211-247.

BUZZELL, R. I. Inheritance of a soybean flowering response to fluorescent-daylenght conditions. Canadian Journal of Genetics \& Cytology, v. 13, p.703-707, 1971.

BUZZELL, R.I. \& VOLDENG, H.D. Inheritance of insensitivity to long daylenght. Soybean Genetics Neswletter, v.7, p.26-29, 1980.

BYTH, D. E.; CALDWELL, B. E.; WEBER, C. R. Specific and non-specific index selection in soybeans, Glycine max L. (Merrill). Crop Science, v.9, p.702-705, 1969.

CAMACHO, L. H. M. Varianzas genéticas y heredabilidad de características vegetativas y reproductivas de la soya Glycine $\max$ (L.) Merr. Acta Agronomica, v.21, n.4, p.145-152, 1971.

CANTO, W. L. \& TURATII, J. M. Produção e mercado de produtos intermediários proteícos de soja no Brasil. Boletim CEPPA, Curitiba, v.7, n.2, p.111-139, 1989.

CARNIELLI, A. Representatividade de parcelas com tamanho reduzido para avaliação de caracteres agronômicos de soja (Glycine max (L.) Merrill). Piracicaba, 1989. 135p. Dissertação (Mestrado) - Escola Superior de Agricultura "Luiz de Queiroz", Universidade de São Paulo.

CARRÃO-PANIZZI, M. C. Breeding soybean for human consumption. In: WORLD SOYBEAN RESEARCH CONFERENCE, 4., Buenos Aires, Argentina, 1989. Proceedings. Buenos Aires, Associacion Argentina de la Soja, 1989, p.1101-1105. 
CARrÃo-PANIZZI, M. C. Soja Proteína para milhões. Ciência Hoje, v.6, n.3, p.25$31,1987$.

CARRÃO-PANIZZI, M. C. Valor nutritivo da soja e potencial de utilização na dieta brasileira. Londrina, EMBRAPA / CNPSo, 1988. 13p. (Documentos 29).

CARTER JR., T. E. \& BOERMA, H. R. Implications of genotype x planting dates and row spacings interactions in double-cropped soybean cultivar development. Crop Science, v. 19, p.607-610, 1979.

CARVALHO, F.I.F.; FEDERIZZI, L.C.; NODARI, R.O.; STORCK, L. Comparison among stability models in evaluating genotypes. Revista Brasileira de Genética, v.6, n.4, p.667-691, 1983.

CAVINESS, C. E. \& PRONGSIRIVATHANA, C. Inheritance and association of plant height and its components in a soybean cross. Crop Science, v.8, p.221-224, 1968.

CECON, P. R.; SEDIYAMA, C. S.; SEDIYAMA, T. Herdabilidade e correlações na geração $F_{3}$ de dezesseis cruzamentos de soja. In: SEMINÁRIO DE PESQUISA DA SOJA, 3., Campinas, 1984a. Anais. Londrina, EMBRAPA/CNPSo, 1984a. p.346-358.

CECON, P. R.; SEDIYAMA, C. S.; SEDIYAMA, T.; SILVA, J. C.; LUDWIG, A. Herdabilidade de alguns caracteres em gerações $F_{2}$ de cruzamentos de soja.. In: SEMINÁRIO DE PESQUISA DA SOJA, 3., Campinas, 1984b. Anais. Londrina, EMBRAPA/CNPSo, 1984b. p.338-345.

CHAUHAN, V. S. \& SINGH, B. B. Genetic variability and heritability in soybean. Indian Journal Agricultural Science, v.54, n.4, p.273-276, 1984.

COOPER, R. L. Response of soybean cultivars to narrow rows and planting rates under weed-free conditions. Agronomy Journal, v.68, p.89-92, 1977. 
CROISSANT, G. L. \& TORRIE, J. H. Evidence of nonadditive effects and linkage in two hybrid populations of soybeans. Crop Science, v.11, p.675-677, 1971.

CRUZ, C.D. \& REGAZZI, A.J. Interação genótipos x ambientes. In: CRUZ, C.D. \& REGAZZI, A.J. Modelos biométricos aplicados ao melhoramento genético. Viçosa; Imprensa Universitária da UFV, 1994. Cap.1 ,p.1-34.

DASHIELL, K. E.; ARIYO, O. J.; BELLO, L.; OJO, K. Genotype x environment interaction and simultaneous selection for high yield and stability in soybean (Glycine $\max ($ L.) Merr.). Annals of Applied Biology, v.124, n.1, p.133-139, 1994.

DAVIES, C. S.; NIELSEN, N. C. Genetic analysis of a null-allele for Lipoxigenase-2 in soybean. Crop Science, v.26, p.460-463, 1986.

DAVIES, C. S.; NIELSEN, S. S.; NIELSEN, N. C. Flavor improvement of soybean preparations by genetic removal of lipoxygenase-2. Journal of the American Oil Chemists Society, v.64, n.10, p.1428-1433, 1987.

DAYDÉ, J.; ECOCHARD, R.; MARMEY,P. The possible influence of cytoplasm on the performance of reciprocal soybean hybrids. Euphytica, v.44, p.49-53, 1989.

DEODHAR, A. D.; LAL, M. S.; SHARMA, Y. K.; MEHTA, S. K. Chemical composition of vegetable type varieties of soybean. The Indian Journal of Nutrition and Dietetics, v.10, p.134-138, 1973.

DESTRO, D. Capacidade de combinação de genótipos de soja [Glycine max (L.) Merrill] apropriados para o consumo humano. Piracicaba, 1991. 158p. Tese (Doutorado) - Escola Superior de Agricultura "Luiz de Queiroz", Universidade de São Paulo.

DUARTE, J.B. Estudo da adaptabilidade e estabilidade fenotípica em cultivares de feijão mulatinho (Phaseolus vulgaris L.). Goiás, 1988, 155p. Dissertação (Mestrado) Escola de Agronomia, Universidade Federal de Goiás. 
DUARTE, J.B. \& ZIMMERMANN, M.J.O. Correlation among yield stability parameters in common bean. Crop Science. v.35, n.3, p.905-912, 1995.

EBERHART, S.A.; RUSSELL, W.A. Stability parameters for comparing varieties. Crop Science, v.6, p.36-40, 1966.

EDWARDS, A. W. F. \& CAVALLI-SFORZA, L. L. A method for cluster analysis. Biometrics, v.21, p.362-375, 1965.

FEHR, W. R. \& CAVINESS, C. E. Stages of soybean development. Iowa State University of Science and Technology, 1977. 12 p. (Special Report, 80).

FEHR, W. R.; WELKW, G. A.; HAMMOND, E. G.; DUVICK, D. N.; CIANZIO, S. R. Inheritance of reduced linolenic acid content in soybean genotypes A16 and A17. Crop Science, v.32, p.903-906, 1992.

FINLAY, K.W. \& WILKINSON, G.N. The analysis of adaptation in a plant-breeding programme. Australian Journal of Agricultural Research. v.14, p.742-754, 1963.

FRANK, S. J. \& FEHR, W. R. Associations among pod dimensions and seed weight in soybeans. Crop Science, v.21, p.547-550, 1981.

FRASER, J.; EGLI, D. B.; LEGGETT, J. E. Pod and seed development in soybean cultivars with differences in seed size. Agronomy Journal, v.74, p.81-85, 1982.

FREIRE FILHO, F. R. Análise genética de uma dialelo entre genótipos precoces de soja [Glycine max (L.) Merrill]. Piracicaba, 1988. 224 p. Tese (Doutorado) - Escola Superior de Agricultura "Luiz de Queiroz", Universidade de São Paulo.

FUCHS, A.; LEIPZIG, G.D.R.; PEREZ PONCE, J. Methods for estimating the yield stability - variety trials with sugar cane. Beitrage zur tropischen landwirtschaft und veterinarmedizin. v.17, n.4, p.351-359, 1979. 
GATES, C. E.; WEBER, C. R.; HORNER, T. W. A Linkage study of quantitative characters in a soybeans cross. Agronomy Journal, v.52, n.45-49, 1960.

GAUCH Jr., H. G. \& ZOBEL, R. W. Accuracy and selection sucess in yield trial analyses. Theoretical and Applied Genetics, v.77, n.4, p.473-481, 1989.

GAUCH Jr., H. G. \& ZOBEL, R. W. Predictive and postdictive sucess of statistical analyses of yield trials. Theoretical and Applied Genetics, v.76, n.1, p.1-10, 1988.

GILIOLI, J. L.; SEDIYAMA, T.; FONSECA JÚNIOR, N. Herança do número de dias para a floração em quatro mutantes naturais em soja. In: SEMINÁRIO DE PESQUISA DA SOJA, 3., Campinas, 1984. Anais. Londrina, EMBRAPA/CNPSo, 1984. p.323-37.

GOMEZ, K.A. \& GOMEZ, A.A. Regression and correlation analysis In: GOMEZ, K.A. \& GOMEZ, A.A. (Ed.) Statistical procedures for agricultural research. New York: John Wiley \& Sons Inc, 1984. cap.9, p.357-423.

GOTOH, K. Historical review of soybean cultivation in Japan. Tropical Agriculture Research Series, v.17, p.135-142, 1984.

GRAY, E. Genotype $\mathrm{x}$ environment interactions and stability analysis for forage yield of orchardgrass clones. Crop Science, v.22, p. 19-23, 1982.

GUPTA, V. P.; GARG, I. K.; RANA, N. D. Genotype $x$ environment interaction in soybean: I. Individual regression analysis. Soybean Genetics Newsletter, v.9, p.45$46,1982 \mathrm{a}$.

GUPTA, V. P.; GARG, I. K.; RANA, N. D. Genotype $x$ environment interaction in soybean: II Joint regression analysis. Soybean Genetics Newsletter, v.9, p.47-50, $1982 b$. 
GUPTA, V. P.; GARG, I. K.; RANA, N. D. Study on biological measures on environment and its implications on the physical limits to seed yield and other developmental traits in soybean. Soybean Genetics Newsletter, v. 8, p.53-61, 1981.

HAFEZ, Y. S. Nutrient composition of different varieties and strains of soybean. Nutrition Reports International, Stoneham, 28(6): 1197-206, 1983.

HAJIKA, M.; IGITA, K.; KITAMURA, K. A line lacking all the seed lipoxigenase isozymes in soybean [Glycine max (L.) Merrill] induced by gamma-ray irradiation. Japanese Journal Breeding, v.41, p.507-509, 1991.

HAJIKA, M.; KITAMURA, K; IGITA, K; NAKAZAWA, Y. Genetic relationships among the genes for lipoxygenase-1, -2 and -3 isozymes in soybean [Glycine max (L.) Merrill] seed. Japanese Journal Breeding, v.42, p.787-792, 1992.

HAMMOND, E. G.; DUVICK, D. N.; FEHR, W. R.; HILDEBRAND, D. F.; LACEFIELD, E. C.; PFEIFFER, T. W. Rapid screening techniques for lipoxigenases in soybean seeds. Crop Science, Madison, 32: 820-1, 1992.

HANSON, W. D. \& WEBER, C. R. Resolution of genetic variability in self-pollinated species with an aplication to the soybean. Genetics, v.46, p.1425-1434, 1961.

HANSON, W. D.; PROBST, A. H.; CALDWELL, B. E. Evaluation of a population of soybeans genotypes with implications for improving self-pollinated crops. Crop Science, Madison, 7: 99-103, 1967.

HARRISON, S. A.; BOERMA, H. R.; ASHLEY, D. A. Heritability of canopy-apparent photosyntesis and its relationship to seed yield in soybeans. Crop Science, v.21, p.222-226, 1981 .

HARTWIG, E. E. Varietal development. In: CALDWELL, B.E., Ed. Soybeans: improvement, production and uses. Madison, Wisconsin: American Society of Agronomy, 1973. cap.6, p.187-210. 
HARTWIG, E. E. \& KIIHL, R. A. S. Identification and utilization of a delayed flowering character in soybeans for short-day conditions. Field Crops Research, v.2, p.145-151, 1979.

HILDEBRAND, D. F. \& HYMOWITZ, T. Inheritance of lipoxygenase-1 activity in soybean seeds. Crop Science, v.22, p.851-853, 1982.

HILDEBRAND, D. F. \& PFEIFFER, T. W. Results from crosses of low linolenate soybean mutants. Soybean Genetics Newsletter, v. 18, p.310-311, 1991.

HILDEBRAND, D. F.; HAMILTON-KEMP, T. R.; LOUGHRIN, J. H.; ALI, K.; ANDERSEN, R. A. Lipoxygenase 3 reduces hexanal prodution from soybean seed homogenates. Journal of Agricultural and Food Chemistry, v.38, n.10, p.1934$1936,1990$.

HINSON, $\mathrm{K}$. Use of a long juvenile trait in cultivar development. In: WORLD SOYBEAN RESEARCH CONFERENCE, 4., Buenos Aires, Argentina, 1989. Proceedings. Buenos Aires, Associacion Argentina de la Soja, 1989. p.983-987.

HONG, E. H.; KIM, S. D.; HWANG, Y. H. Production and use of and research on soybeans in Korea. Tropical Agriculture Research Series, Tokio, 17: 81-93, 1984.

HÜHN, M. \& LÉON, J. Genotype x environment interactions and phenotypic stability of Brassica napus. Zeitschrift Pflanzenzücht, v.95, p.135-146, 1985.

HYMOWITZ, T.; COLLINS, F. I.; PANCZNER, J.; WALKER, W. M. Relationship between the content of oil, protein and sugar in soybean seed. Agronomy Journal, v.64, p.613-616, 1972.

IEMMA, A.F. VI. Parâmetros que descrevem a posição ou a tendência central In: IEMMA A.F. (Ed.) Estatística descritiva. Piracicaba: $\varphi \sigma \rho$ publicações. 1992a. cap.VI, p.87-107. 
IEMMA, A.F. VIII. Outros parâmetros e aplicações In: IEMMA A.F. (Ed.) Estatística descritiva. Piracicaba: $\varphi \sigma \rho$ publicações. 1992b. cap.VIII, p.123-136.

ЛАN, Y. Y. Situation of soybean production and research in China. Tropical Agriculture Research Series, v.17, p.67-72, 1984.

JOHNSON, H. W ; ROBINSON, H. F.; COMSTOCK, R. E. Genotypic and phenotypic correlations in soybeans and their implications in selection. Agronomy Journal, v. 47, n. 10, p. $477-483,1955$.

JOWETT, D. Yield stability parameters for sorghum in East Africa. Crop Science, v.12, p.314-317, 1972.

KANE, M. V. \& GRABAU, L. J. Early planted, early maturing soybean cropping system: growth, development, and yield. Agronomy Journal, v.84, n.5, p.769-773, 1992.

KANG, M.S. \& MILLER, J.D. Genotype $\mathrm{x}$ environment interactions for cane and sugar yield and their implications in sugarcane breeding. Crop Scince, v.24, p.435-440, 1984.

KIIHL, R. A. S. \& GARCIA, A. The use of long-juvenile trait in breeding soybean cultivars. In: WORLD SOYBEAN RESEARCH CONFERENCE, 4., Buenos Aires, Argentina, 1989. Proceedings. Buenos Aires, Associacion Argentina de la Soja, 1989. p. $994-1000$.

KIIHL, R.A.S. Inheritance studies of two characteristics in soybeans (Glycine max (L.) Merrill) I. Resistance to soybean mosaic virus. II. Late flowering under short day conditions. Mississipi, 1976. 56p. Thesis (Ph.D.) - Mississipi State University.

KITAMURA, K; DAVIES, C. S.; KAIZUMA, N.; NIELSEN, N. C. Genetic analysis of a null-allele for lipoxygenase-3 in soybean seeds. Crop Science, v.23, p.924-927, 1983. 
KONOVSKY, J.; EVANS, D.W.; LUMPKIN, T.A. Heritability of yield, plant architecture, and quality traits of edamame: the vegetable soybean. Soybean Genetics Newsletter. v.23, p.243-249, 1996.

KROONENBERG, P. M. \& BASFORD, K. E. An investigation of multi-attribute genotype response across environments using three-mode principal component analysis. Euphytica, v.44, n.1-2, p.109-123, 1989.

KWON, S. H. \& TORRIE, J. H. Heritability of and interrelationships among traits of two populations. Crop Science, v.4, p.196-198, 1964.

LANE, D.M. Describing Univariate Data. http://www.ruf.rice.edu/-lane/hyperstat/A37797.html. 26/11/1998.

LAWN, R. J. \& HUME, D. J. Response of tropical and temperate soybean genotypes to temperature during early reprodutive growth. Crop Science, v.25, n.1, p.137-142, 1985.

LAWN, R. J. \& IMRIE, B. C. Crop improvement for tropical and subtropical Australia: designing plants for difficult climates. Field Crops Research, v.26, n.2, p.113-139, 1991.

LEFFEL, R. C. \& HANSON, W. D. Early generation testing of diallel crosses of soybeans. Crop Science, v.1, p.169-174, 1961.

LEFFEL, R. C. \& WEISS, M. G. Analyses of diallel crosses among ten varieties of soybeans. Agronomy Journal, v.50, p.528-534,1958.

LEHMAN, W. F. \& LAMBERT, J. W. Effects of spacing of soybean plants between and within rows on yield and its components. Agronomy Journal, v.52, p.84-86, 1960.

LEROY, A. R.; FEHR, W. R.; RODRIGUEZ DE CIANZIO, S. Introgression of genes for small seed size from Glycine soja into G. max. Crop Science, v.31, p.693-697, 1991. 
LI, Y.J.; CHANG, R.Z.; ZHAO, Y.T.; SUN, J.Y. Application studies in the field on screening for cold-tolerance in the laboratory in soybeans. Soybean Genetics Neswletter, v.17, p.32-42, 1990.

LIN, C. S. \& BINNS, M. R. A superiority measure of cultivar performance for cultivar $x$ location data. Canadian Journal of Plant Science, v.68, n.1, p.193-198, 1988.

LIN, M. S. \& NELSON, R. L. Relationship between plant height and flowering date in determinate soybean. Crop Science, v.28, p.27-30, 1988.

MA, S.J.; ZHANG, Y.H.; XUE, Q.X.; WU, H.L.; LIU, H.Q.; SHANG, S.G.; HUO, H; WANG, F.L.; GAO, G.J. Evaluation of resistance of soyabean germplasms to race 3 of soyabeans cyst nematode. Soybean Science, v.2, n.2, p.165-171, 1991.

MAGA, J. A. A review of flavor investigations associated with the soy products raw soybeans, defatted flakes and flour, and isolates. Journal of Agricultural and Food Chemistry, v.21, n.5, p.864-868, 1973.

MAY, M. L.; CAVINESS, C. E.; ELDRIDGE, I. L. Soybean response to early planting in Northeast Arkansas. Arkansas Farm Research, v.38, n.4, p.5, 1989.

McBLAIN, B. A. \& BERNARD, R. L. A new gene affecting the time of flowering and maturity in soybeans. The Journal of Heredity, v.78, p.160-162, 1987.

MIRANDA, M. A. C.; SUASSUNA FILHO, J.; BUSILANI, E. A.; MASCARENHAS, H. A. A.; TISELLI FILHO, O; BRAGA, N .R. Efeito maternal e do genótipo sobre o teor de óleo e tamanho de sementes $\mathrm{F}_{1}$ de soja. In: SEMINÁRIO NACIONAL DE PESQUISA DE SOJA, 3. Anais. Londrina, EMBRAPA/CNPSo, 1984. p.308-317.

MOHAMED, A. I. \& RANGAPPA, M. Screening soybean (grain and vegetable) genotypes for nutrients and anti-nutritional factors. Plant Foods for Human Nutrition, v.42, p.87-96, 1992. 
MOHAMED, A. I.; MEBRAHTU, T.; RANGAPPA, M. Nutrient composition and antinutritional factors in selected vegetable soybean (Glycine max [L.] Merr.). Plant Foods for Human Nutrition, v.41, p.89-100, 1991.

MOHAMED, A.I. \& PEARSON, N. Location by genotype interaction effects on chemical composition of immature large seeded vegetable-type soybeans. Soybean Genetics Newsletter. v.24, p.211-213, 1997.

MONTGOMERY, D.C. Experiments with a single factor: The analysis of variance In: Montgomery, D.C. (Ed.) Design and Analysis of Experiments $3^{*}$ ed., John Wiley \& Sons Inc., Singapore, 1991b. cap.3, p.50-94.

MONTGOMERY, D.C. Simple comparative experiments In: Montgomery, D.C. (Ed.) Design and Analysis of Experiments $3^{\circ}$ ed., John Wiley \& Sons Inc., Singapore, 1991a. cap.2, p.14-49.

MOREIRA, M. A.; SEDIYAMA, C. S.; GOMES, J. C.; CHAVES, J. B. P.; ARAÚJO, E. F.; REZENDE, S. T. Desenvolvimento de cultivares de soja com sementes de melhor qualidade e sabor para alimentação humana. In: SIMPÓSIO INTERNACIONAL NOVOS RUMOS DA GENÉTICA E BIOTECNOLOGIA EM PLANTAS, ANIMAIS E MICRORGANISMOS NA AGROINDÚSTRIA, Piracicaba, 1991. Anais; editado por G. Bandell; A. A.; Pizzirani-Kleiner; J. L.; Azevedo, Piracicaba, ESALQ-Departamento de Genética; FEALQ, 1991. p. 57-62.

MORO, G.L.; REIS, M.S.; SEDIYAMA, C.S.; SEDIYAMA, T.; OLIVEIRA, A.B. Correlações entre alguns caracteres agronômicos em soja (Glycine max (L.) Merrill). Revista Ceres. v.39, n.223, p.225-232, 1992.

MUGNISJAH, W.Q.; SHIMANO, I.; MATSUMOTO, S. Studies on the vigour of soybean seeds. I. Varietal differences in seed vigour. Journal of the Facullty of Agriculture, Kyushu University, v.31, n.3, p.213-226, 1987. 
NGUYEN, H.T.; SLEPER, D.A.; HUNT, K.L. Genotype x environment interactions and stability analysis for herbage yield of tall fescue synthetics. Crop Science, v.20, p.221-224, 1980.

ORF, J. H. Breeding soybeans lacking antinutritional factors. In: WORLD SOYBEAN RESEARCH CONFERENCE, 4., Buenos Aires, Argentina, 1989. Proceedings. Buenos Aires, Associacion Argentina de la Soja, 1989. p.1091-1100.

PACOVA, B. E. V. Análise genética de progênies segregantes de soja apropriada para o consumo humano. Piracicaba, 1992. 217 p. Tese (Doutorado) - Escola Superior de Agricultura "Luiz de Queiroz", Universidade de São Paulo.

PARKER, M. B.; MARCHANT, W. H.;MULLINIX Jr., B. J. Date of planting and row spacing effects on four soybean cultivars. Agronomy Journal, v.73, n.5, p.759-762, 1981.

PEREIRA, M. G.; SEDIYAMA, T.; SEDIYAMA, C. S.; CASALI, V. W. D.; SILVA, R. F. Herdabilidade de caracteres agronômicos de genótipos de soja, descendentes de dois processos de seleção. In: SEMINÁRIO DE PESQUISA DA SOJA, 3., Campinas, 1984. Anais. Londrina, EMBRAPA/CNPSo, 1984. p.521-527.

PFEIFFER, T. W. Selection for late-planted soybean yield in full-season and late-planted environments. Crop Science, v.27, n.5, p.963-967, 1987.

PFEIFFER, T. W.; GRABAU, L. J.; ORF, J. H. Early maturity soybean production system: genotype $\mathrm{x}$ environment interaction between regions of adaptation. Crop Science, v.35, n.1, p.108-112, 1995.

PFEIFFER, T. W.; HILDEBRAND, D. F. Test for linkage between $\mathrm{lxl}$ and $\mathrm{ln}, \mathrm{pc}, \mathrm{f}, \mathrm{i}, \mathrm{r}$, dt1, lf1, and pl Soybean Genetics Newsletter, v.18, p.306-307, 1991.

PFEIFFER, T. W.; HILDEBRAND, D. F.; ORF, J. H. Inheritance of a lipoxygenase-1 allozyme in soybean. Crop Science, v.33, p.691-693, 1993. 
PFEIFFER, T. W.; HILDEBRAND, D. F.; TeKRONY, D. M. Agronomic performance of soybean lipoxygenase isolines. Crop Science, v.32, p.357-362, 1992.

PIMENTEL GOMES, F. Análise de grupos de experimentos In: Gomes, F.P. (Ed.) Curso de Estatística Experimental. Piracicaba: Nobel, 1991. 14a.ed., cap.8, p168-197.

PLAISTED, R.L. \& PETERSON, L.C. A technique for evaluating the ability of selections to yield consistently in different locations or seasons. American Potato Journal. v.36, p.381-385, 1959.

RACKIS, J. J.; HONIG, D. H.; SESSA, D. J.; MOSER, H. A. Lipoxigenase and peroxidase activities of soybeans as related to the flavor profile during maturation. Cereal Chemistry, v.49, p.585-597, 1972.

RACKIS, J. J.; SESSA, D. J.; HONIG, D. H. Flavor problems of vegetable food proteins. Journal of the American Oil Chemists Society, v.56, n.3, p.262-271, 1979.

RAIZER, A.J. Interação genótipos $\mathrm{x}$ ambientes e estabilidade fenotípica em cana-deaçúcar no Estado de São Paulo. Piracicaba, 1998. 103 p. Dissertação (Mestrado) Escola Superior de Agricultura "Luiz de Queiroz", Universidade de São Paulo.

RITCHIE, S.W.; HANWAY, J.J.; THOMPSON, H.E.; BENSON, G.O. How a soybean plant develops. Iowa: Iowa State University of Science and Technology. Cooperative Extension Service. Special Report 53. 20p, 1985.

ROGNLI, O.A. Genetic variation in artic populations of timothy (Phleum pratense L.) II. Phenotypic stability of seed production. Hereditas, v.107, n.1, p.75-94, 1987.

ROSE, S. Major ion variation and efflux related to discharge in a mafic Piedmont Province watershed. Hydrological-Processes, v.8, n.5, p.481-496, 1994. 
SAKA, K.; SHIPE, E.R.; WALLACE, S.U. Relationships among plant characters in soybean with different seed size. Soybean Genetics Newsletter. v.23, p.225-229, 1996.

SAKIYAMA, N. S.; SEDIYAMA, T.; SEDIYAMA, C. S.; REIS, M. S. Interação genótipo $\mathrm{x}$ ambiente e seus efeitos na escolha de localidades para avaliação de linhagens de soja (Glycine max (L.) Merrill). Revista Ceres, v.35, n.201, p.486$493,1988$.

SANTOS, A. L. C. Variabilidade entre genótipos de soja (Glycine max (L.) Merrill) nas fases imatura e madura de desenvolvimento. Piracicaba, 1988. 135 p. Dissertação (Mestrado) - Escola Superior de Agricultura "Luiz de Queiroz", Universidade de São Paulo.

SANTOS, C.A.F.; REIS, M.S.; SEDIYAMA, C.S.; CRUZ, C.D.; SEDIYAMA, T. Parâmetros genéticos e seleção indireta em progênies $\mathrm{F}_{6}$ de um cruzamento de soja (Glycine max (L.) Merrill). Revista Ceres. v.42, n.240, p.155-166, 1995.

SÃO PAULO (Estado). Secretaria de Agricultura e Abastecimento. Comissão Técnica № 17 - Soja e outras leguminosas. Regimento interno do sistema de avaliação e recomendação de cultivares de soja para o Estado de São Paulo. São Paulo: Secretaria de Agricultura e Abastecimento, 1990. 15p.

SCHMID, J. \& KELLER, E. R. The behavior of three cold-tolerant and a standart soybean variety in relation to the level and the duration of a cold stress. Canadian Journal of Plant Science, v.60, n.3, p.821-829, 1980.

SCHNEBLY, S. R. \& FEHR, W. R. Effect of years and planting dates on fatty acid composition of soybean genotypes. Crop Science, v.33, n.4, p.716-719, 1993.

SCOTT, A. J. \& KNOTT, M. A cluster analysis method for grouping means in the analysis of variance. Biometrics, v.30, p.507-512, 1974. 
SHANMUGASUNDARAM, S. \& CHUNG-RUEY, Y. Screening for immature green soybeans as a vegetable. Soybean Genetics Newsletter, v.9, p.95-96, 1982.

SHANMUGASUNDARAM, S.; TSOU, S.C.S. Photoperiod and critical duration for flower induction in soybeans. Crop Science, v.18, p.598-601, 1978.

SHANMUGASUNDARAM, S.; TSOU, S.C.S.; CHENG, S.H. Vegetable soybeans in the East. In: WORLD SOYBEAN RESEARCH CONFERENCE, 4., Buenos Aires, Argentina, 1989. Proceedings. Buenos Aires, Associacion Argentina de la Soja, 1989. p.1979-1986.

SHUKLA, G.K. Some statistical aspects of partitioning genotype-environmental components of variability. Heredity, v.29, p.237-245, 1972.

SHUKLA, S. \& PUSHPENDRA, K.S. Correlation and path coefficient analysis of yield and its components in soybean (Glycine max (L.) Merrill). Soybean Genetics Newsletter. v. 25, p.67-70, 1998

SILVA, J.G.C. \& BARRETO, J.N. Aplicação de regressão linear segmentada em estudos da interação genótipo $\mathrm{x}$ ambiente. In: Fundação Cargill (Ed.) Simpósio de estatística aplicada à experimentação agronômica. 22-26/07/1985, Campinas, 1985, p. $49-50$.

SINCLAIR, T. R. \& HINSON, K. Soybean flowering in response to the long-juvenile trait. Crop Science, v.32, p.1242-1248, 1992.

SINGH, T. P.; SINGH, K. B.; BRAR, J. S. Diallel analysis in soybean. Indian Journal of Genetics and Plant Breeding, v.34, n.3, p.427-432, 1974.

STARZING, E.K.; WEST, S.H.; HINSON, K. An observation on the relationship of soybean seed coat color to viability maintenance. Seed Science \& Technology, v.10, p.301-305, 1982. 
TAI, G.C.C. Genotypic stability analyses and its application to potato regional trials. Crop Science, v.2, p. 184-194, 1971.

TAIRA, H. Quality of soybeans for processed foods in Japan. Japan Agricultural Research Quarterly, v.24, n.3, p.224-230, 1990.

TINIUS, C.; BLRTON, J. W.; HINSON, K. Effect of temperature on expression of the impermeable seed coat trait. Soybean Genetics Newsletter, v.16, p. 196-198, 1989.

TOLEDO, J. F. F. de \& KIIHL, R. A. S. Análise dialélica do modelo genético envolvido no controle de dias para o florescimento em soja. Pesquisa Agropecuária Brasileira, v. 17, n.5, p.623-631, 1982a.

TOLEDO, J. F. F. de \& KIIHL, R. A. S. Métodos de análise dialélica do modelo genético em controle das características dias para floração e número de folhas trifoliadas. Pesquisa Agropecuária Brasileira, v.17, n.5, p.745-755, 1982b.

UNANDER, D. W.; ORF, J. H.; LAMBERT, J. W. Early season cold tolerance in soybean. Crop Science, v.26, n.4, p.676-678, 1986.

VEGA O., U.A. Comparacion de diferentes parametros de estabilidad del rendimento en trigo. Revista de la Facultad de Agronomia, v.13, n.1-4, p.291-309, 1984.

VELLO, N. A. Ampliação da base genética do germoplasma e melhoramento da soja na ESALQ-USP. In: CÂMARA, G. M. S.; MARCOS FLLHO, J.; OLIVEIRA, E. A. M. (Ed.) Simpósio sobre cultura e produtividade da soja. Piracicaba, FEALQ, 1992a. p. $60-81$.

VELLO, N. A.; FEHR, W. R.; BAHRENFUS, J. A. Genetic variability and agronomic performance of soybean populations developed from plant introduction. Crop Science v.24, p.511-514, 1984. 
VELLO, N.A.; HIROMOTO, D.M.; AZEVEDO FILHO, A.J.B.V. Coefficient of parentage and breeding of Brazilian soybean germplasm. Revista Brasileira de Genética, v.11, p.679-697, 1988.

VENCOVSKY, R. Associação entre caracteres. In: VENCOVSKY, R. \& BARRIGA, P. (Ed.) Genética Biométrica no Fitomelhoramento. Ribeirão Preto, Sociedade Brasileira de Genética, 1992b. cap. 5, p. 335-434.

VENCOVSKY, R. Componentes da variação fenotípica: Análise em vários ambientes. In: VENCOVSKY, R. \& BARRIGA, P. (Ed.) Genética Biométrica no Fitomelhoramento. Ribeirão Preto, Socidade Brasileira de Genética, 1992a. cap. 4, p. 233-333.

WATANABE, I. \& NAGASAWA, T. Appearance and chemical composition of soybean seeds in germplasm collection of Japan I . Frequency distribution of grain size, seed coat colour, hilum colour and content of chemical components, with especial reference to collection site. Japanese Journal of Crop Science, v.59, n.4, p.649$660,1990$.

WEAVER, D. B. \& WILCOX, J. R. Heritabilities, gains from selection, and genetic correlations for characteristics of soybeans grown in two row spacings. Crop Science, v.22, p.625-629, 1982.

WEBER, C. R. \& MOORTHY, B. R. Heritable and nonheritable relationship and variability of oil content and agronomic characters in the $F_{2}$ generation of soybean crosses. Agronomy Journal, v.44, n.4, p.202-209, 1952

WRICKE, G. Zur berechnung der okovalenz bei sommerweizen und hafer. Zeitschrift Pflanzezzuchtg. v. 52, p. 127-138, 1965.

XIAGXUN, M; SHUMING, W.; AIPING, L.; MINGXIANG, H. Protein and oil content of soybean seed as influenced by years and location. Soybean Genetics Newsletter, v.18, p.113-116, 1991. 
YOKOMIZO, G.K. Desempenho e variabilidade de topocruzamentos $F_{5: 4}$ tipo alimento x tipo grão em soja. Piracicaba, 1994. 121 p. Dissertação (Mestrado) - Escola Superior de Agricultura "Luiz de Queiroz", Universidade de São Paulo.

YOKOMIZO, G.K. \& VELLO, N.A. Use of pod width as visual score in substitution of one hundred seed weight on vegetable soybean. Soybean Genetics Neswletter. v.25, p. 21-22, 1998.

YUE, G.L .; ROOZEBOOM, K.L.; SCHAPAUGH Jr., W.T.; LIANG, G.H. Evaluation of soybean cultivars using parametric and nonparametric stability estimates. Plant Breeding, v.116, n.3, p.271-275, 1997.

YUE, G.L.; HEER, W.F.; MOYER, J.L.; MADDUX, L.D.; SORENSEN, E.L; LIANG, G.H. Comparison of nonparametric and parametric stability estimates to evaluate alfafa cultivars. Journal of Genetics and Breeding, v.50, n.1, p.67-74, 1996. 
TABELAS E FIGURAS 
Tabela 1. Relação das progênies de soja (N USP) avaliadas nos experimentos, com o número $(\mathrm{N})$ de identificação empregado na discussão, o número do topocruzamento em 1994 (NC 94) de que foram provenientes, suas respectivas genealogias e, identificação das testemunhas. Soja, Piracicaba, 1996/1997.

\begin{tabular}{|c|c|c|c|c|}
\hline $\mathrm{N}$ & NUSP & NC 94 & Genealogias & \\
\hline \multicolumn{5}{|c|}{ Progênies: } \\
\hline 1 & USP98-06004 & $30-6366$ & (TK \# 5 x Unknown F7) & x Doko \\
\hline 2 & USP98-06006 & $39-6317$ & $(\mathrm{TN} \# 4 \times$ x PI 230.970 F7-4) & x Doko \\
\hline 3 & USP98-06007 & $42-6336$ & $(\mathrm{KS} 473 \times \mathrm{SJ} 2-\mathrm{F} 7)$ & x Doko \\
\hline 4 & USP98-06009 & $48-6323$ & TMV & $\mathrm{x}$ Doko \\
\hline 5 & USP98-06010 & $57-6310$ & PI 230.977 & x Doko \\
\hline 6 & USP98-06011 & $66-6371$ & Araçatuba & x Doko \\
\hline 7 & USP98-06012 & $72-6313$ & Late Giant & $\mathrm{x}$ Doko \\
\hline 8 & USP98-06013 & $72-6328$ & Late Giant & x Doko \\
\hline 9 & USP98-06014 & $72-6340$ & Late Giant & x Doko \\
\hline 10 & USP98-06015 & $72-6353$ & Late Giant & $\mathrm{x}$ Doko \\
\hline 11 & USP98-06016 & $72-6362$ & Late Giant & x Doko \\
\hline 12 & USP98-06017 & $72-6367$ & Late Giant & x Doko \\
\hline 13 & USP98-06018 & $72-6373$ & Late Giant & x Doko \\
\hline 14 & USP98-06019 & $75-6359$ & Japão 1 & x Doko \\
\hline 15 & USP98-06021 & $78-6341$ & Japão 2 & x Doko \\
\hline 16 & USP98-06023 & $93-6329$ & Aliança Preta & x Doko \\
\hline 17 & USP98-06024 & $93-6342$ & Aliança Preta & $\mathrm{x}$ Doko \\
\hline 18 & USP98-06025 & $93-6343$ & Aliança Preta & x Doko \\
\hline 19 & USP98-06026 & $93-6376$ & Aliança Preta & x Doko \\
\hline 20 & USP98-06027 & $95-6363$ & PL-1 & x FT-2 \\
\hline 21 & USP98-06028 & $99-6330$ & FC $31-665$ & x Doko \\
\hline 22 & USP98-06029 & $105-6383$ & Majos & $\mathrm{x}$ Doko \\
\hline 23 & USP98-06031 & $107-6378$ & PI 165.672 & $\mathrm{x}$ Doko \\
\hline 24 & USP98-06032 & $117-6345$ & Tadacha & $\mathrm{x}$ Doko \\
\hline
\end{tabular}

Testemunhas:

IAC PL-1

Tamba

Late Giant

Nimame 


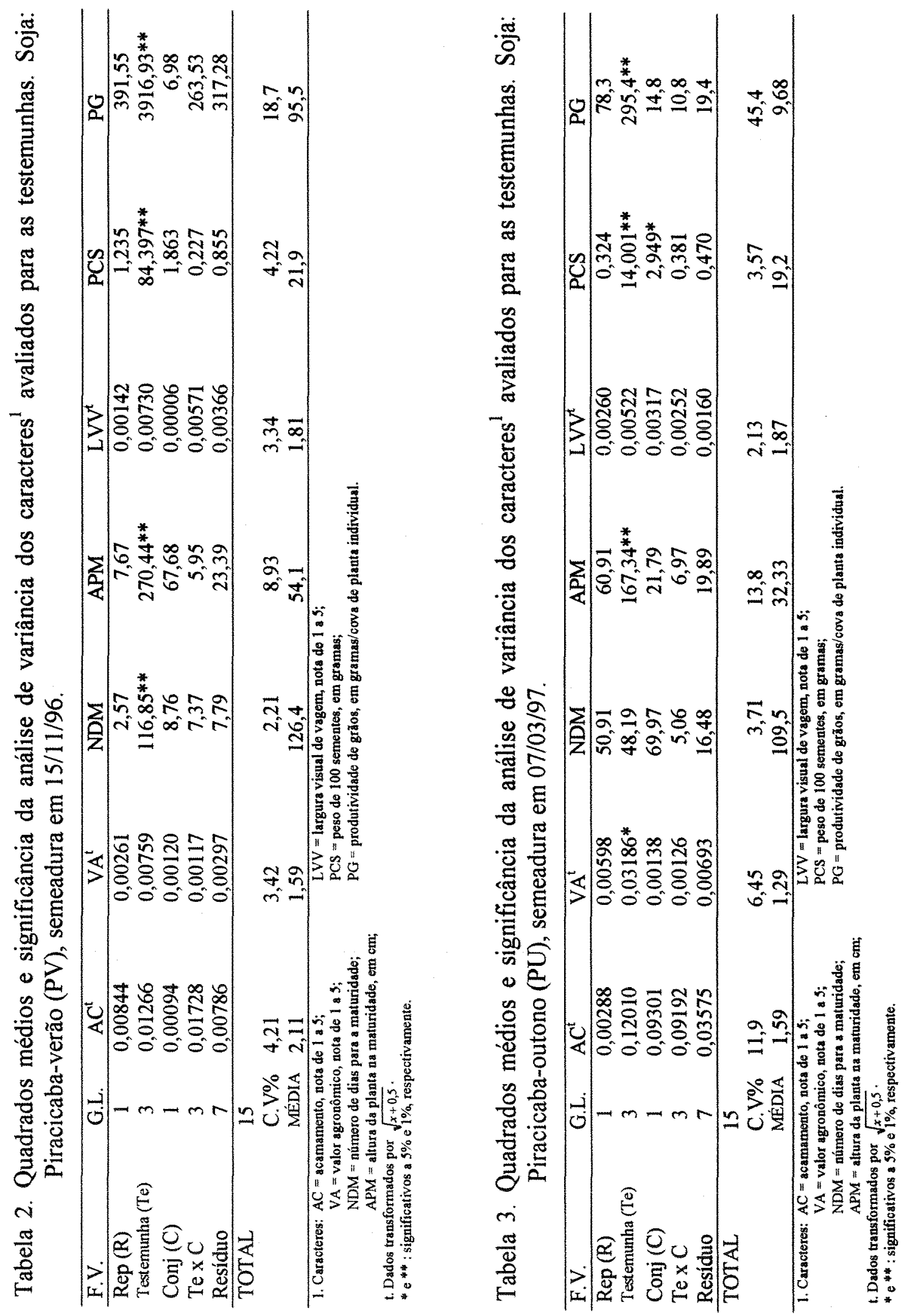




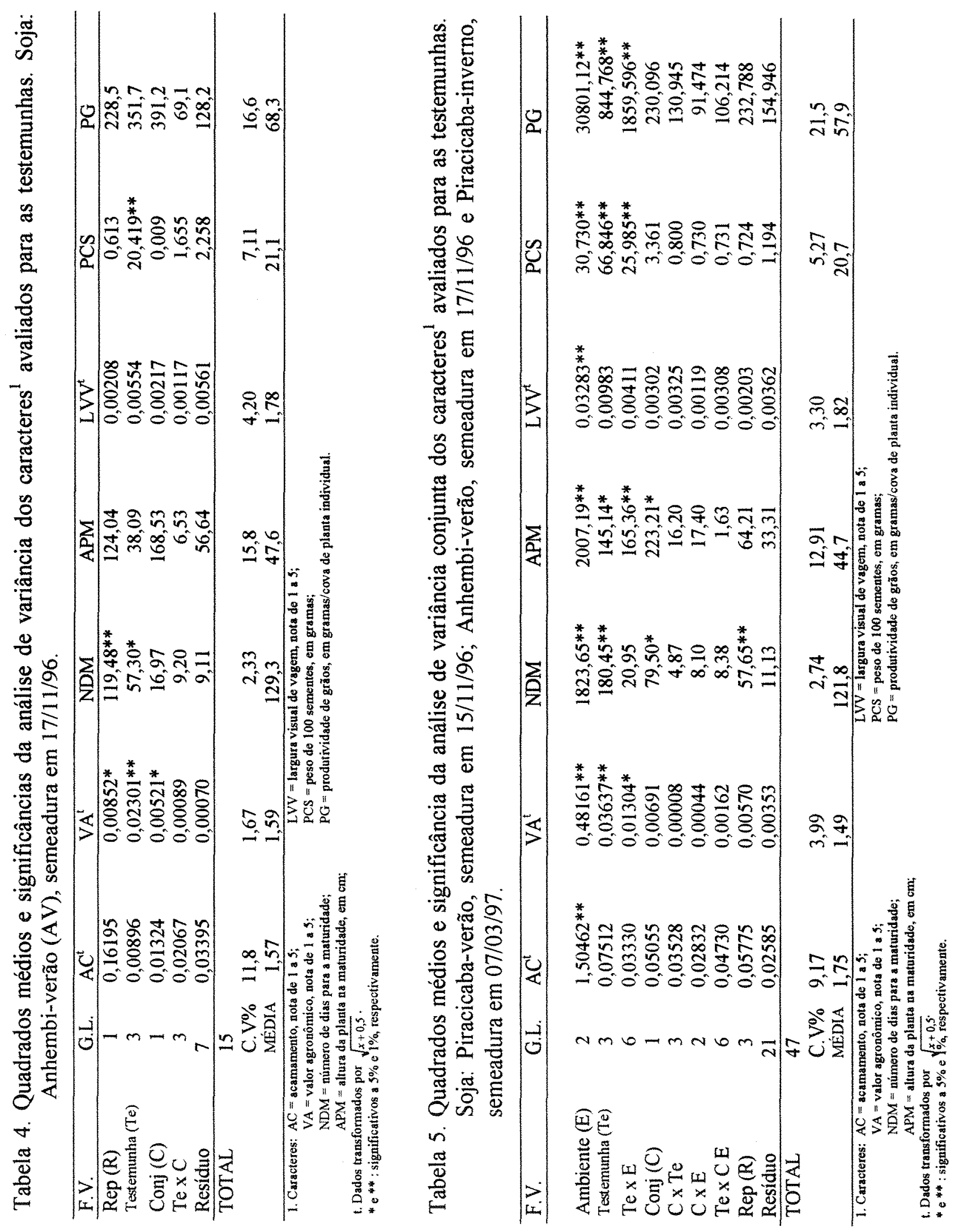




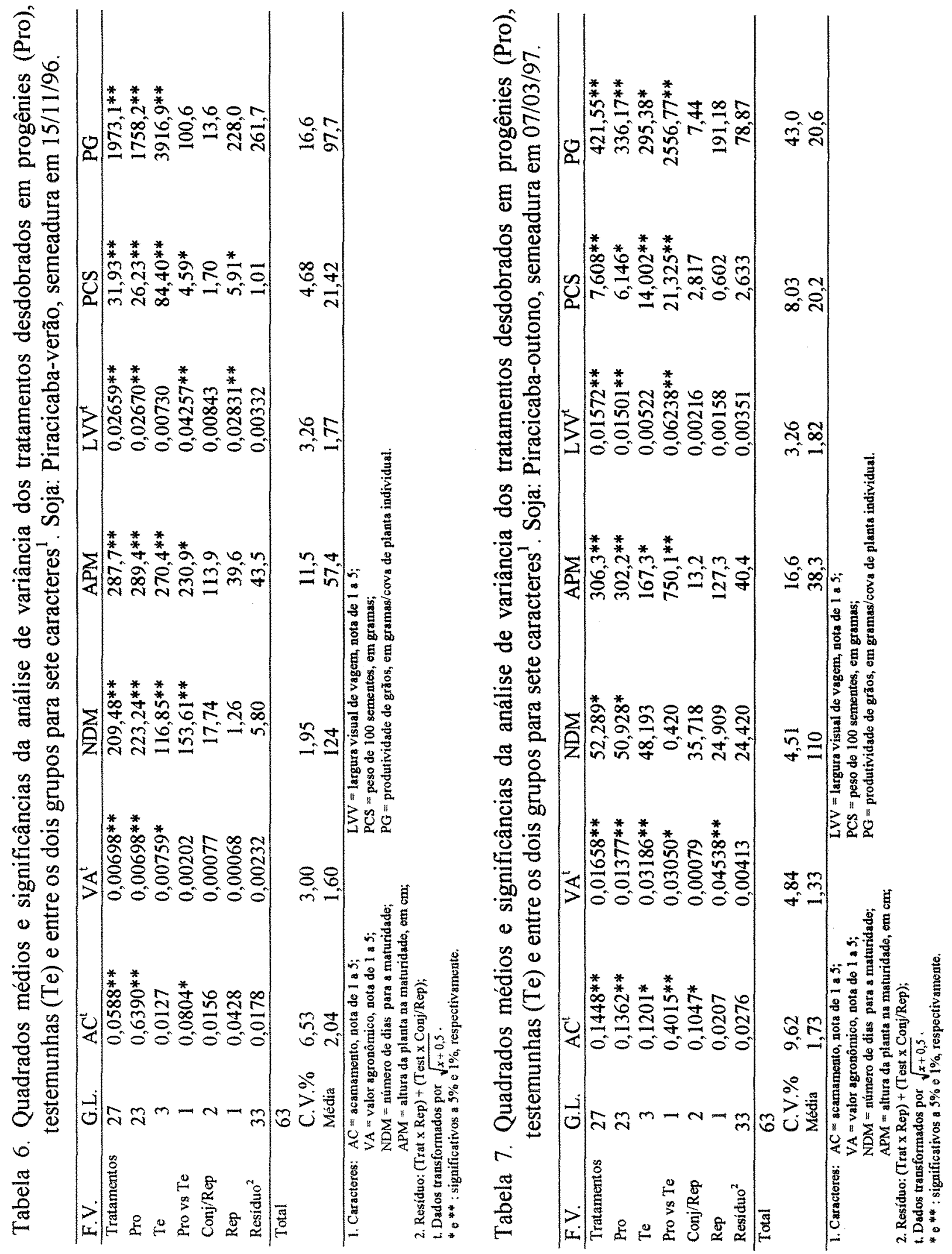




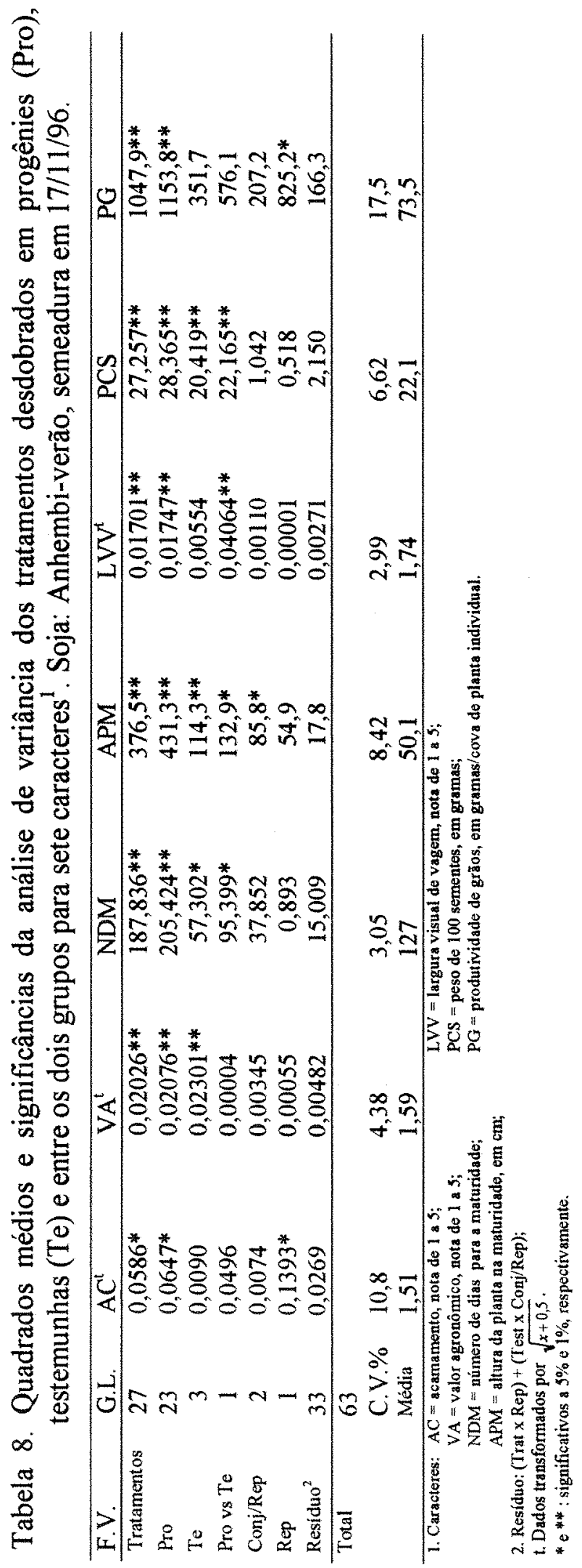




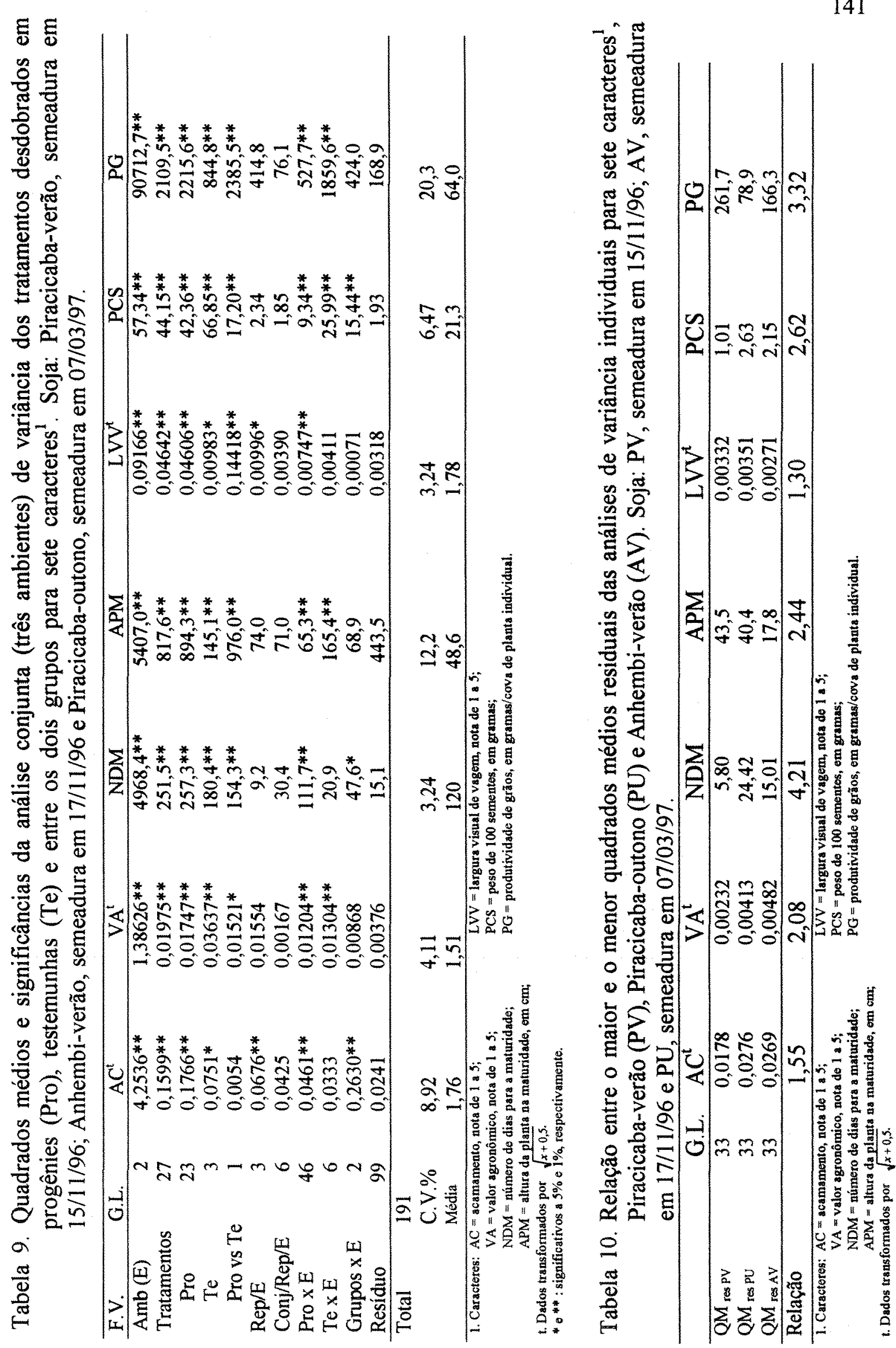




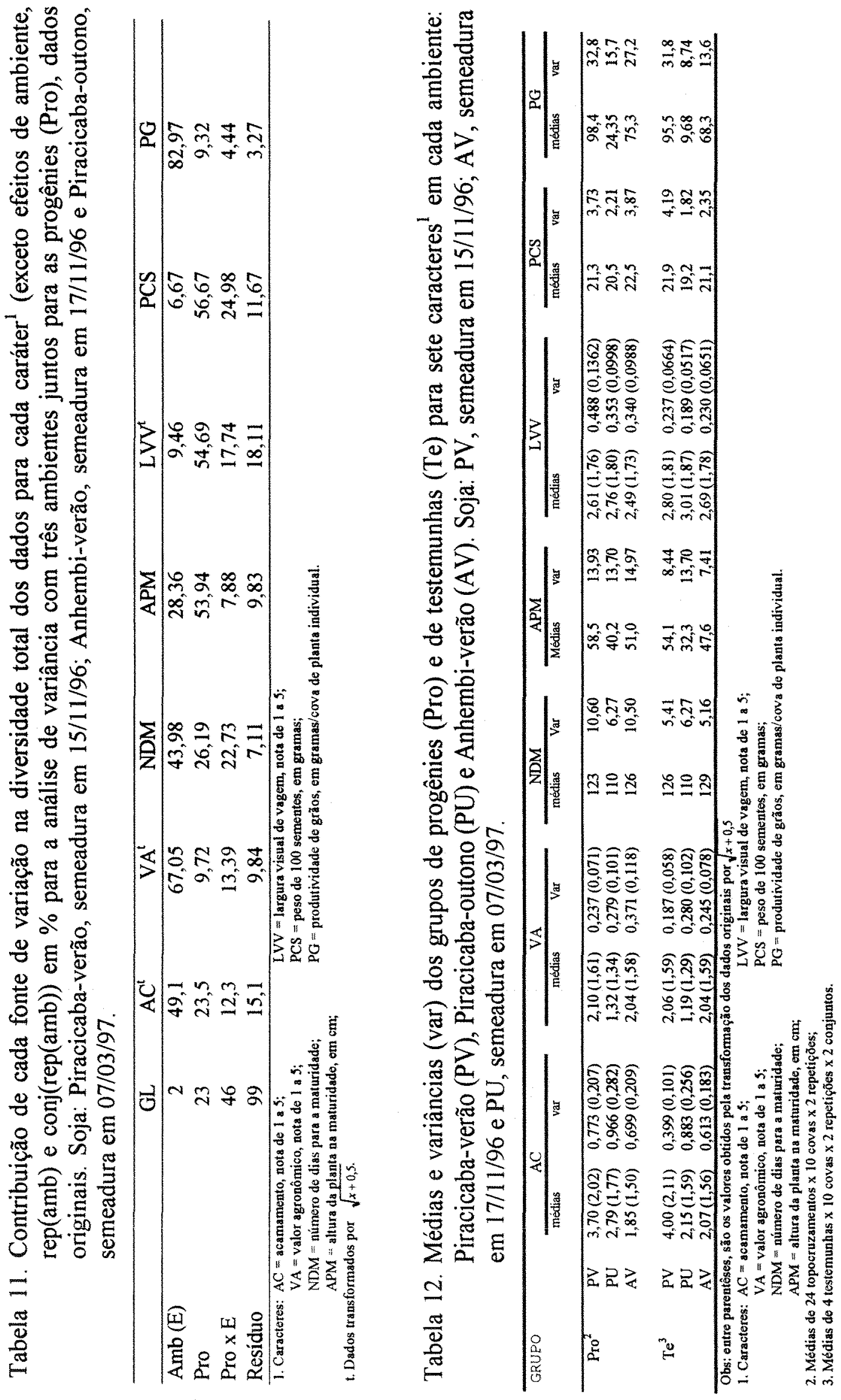




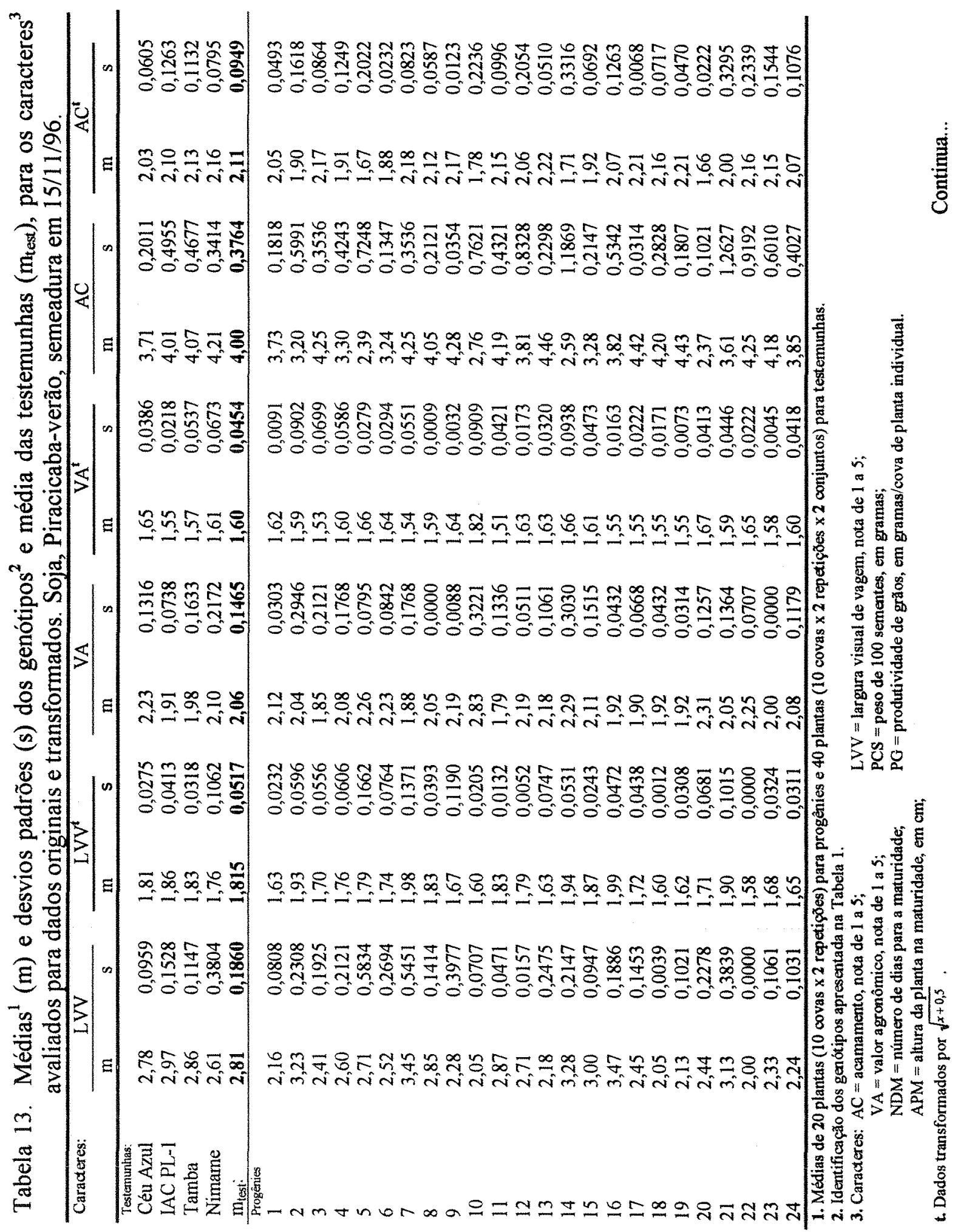




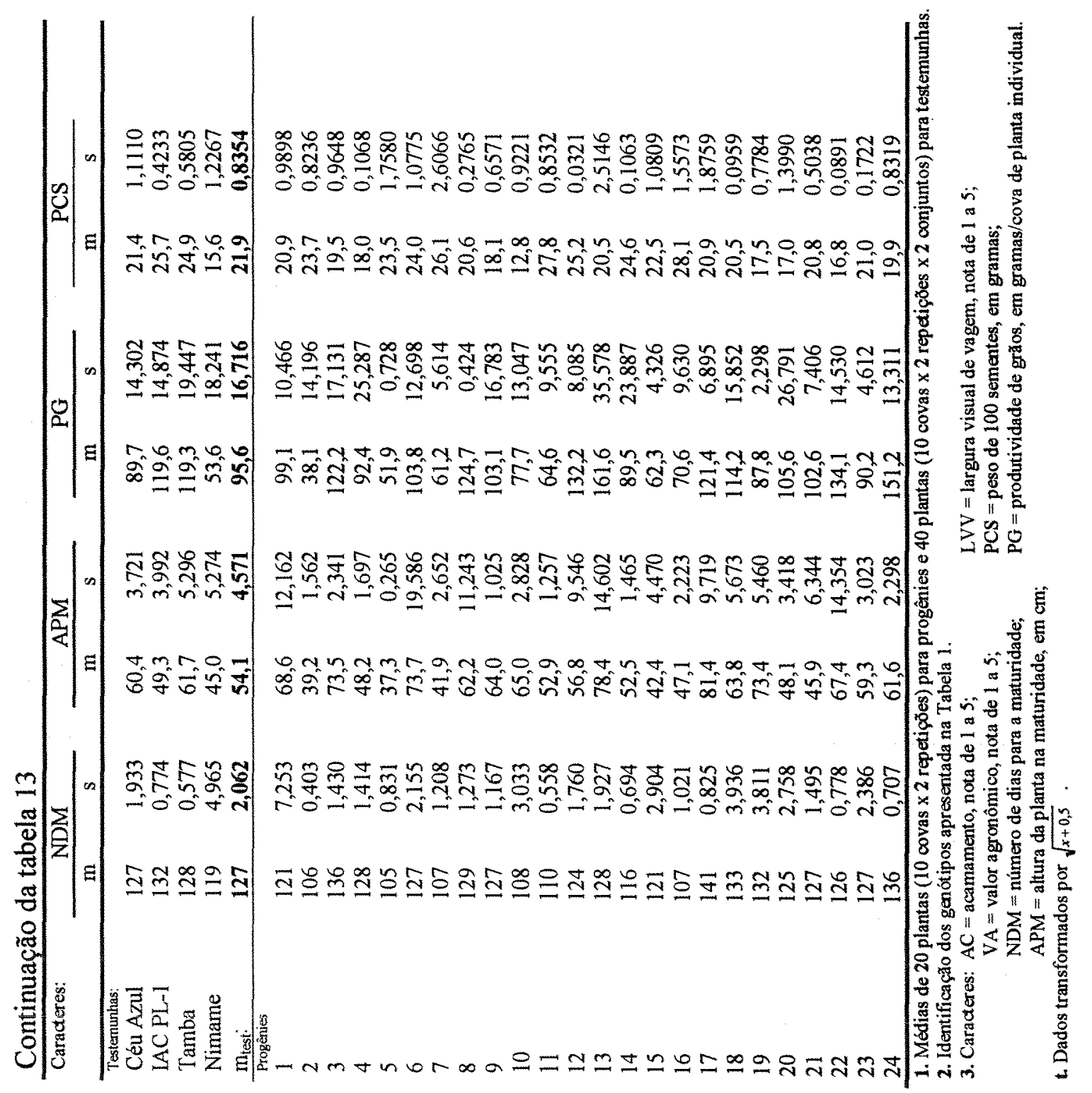




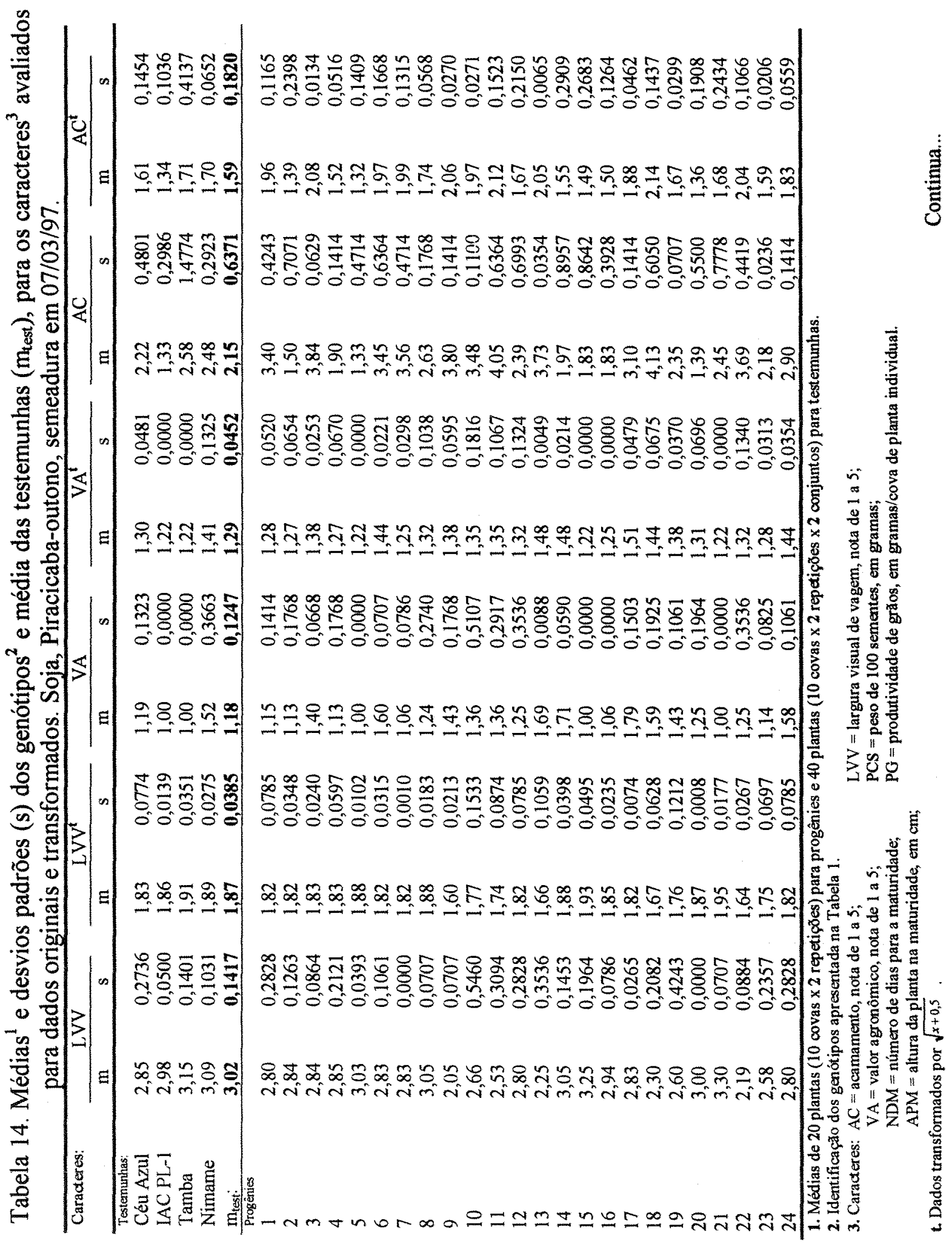




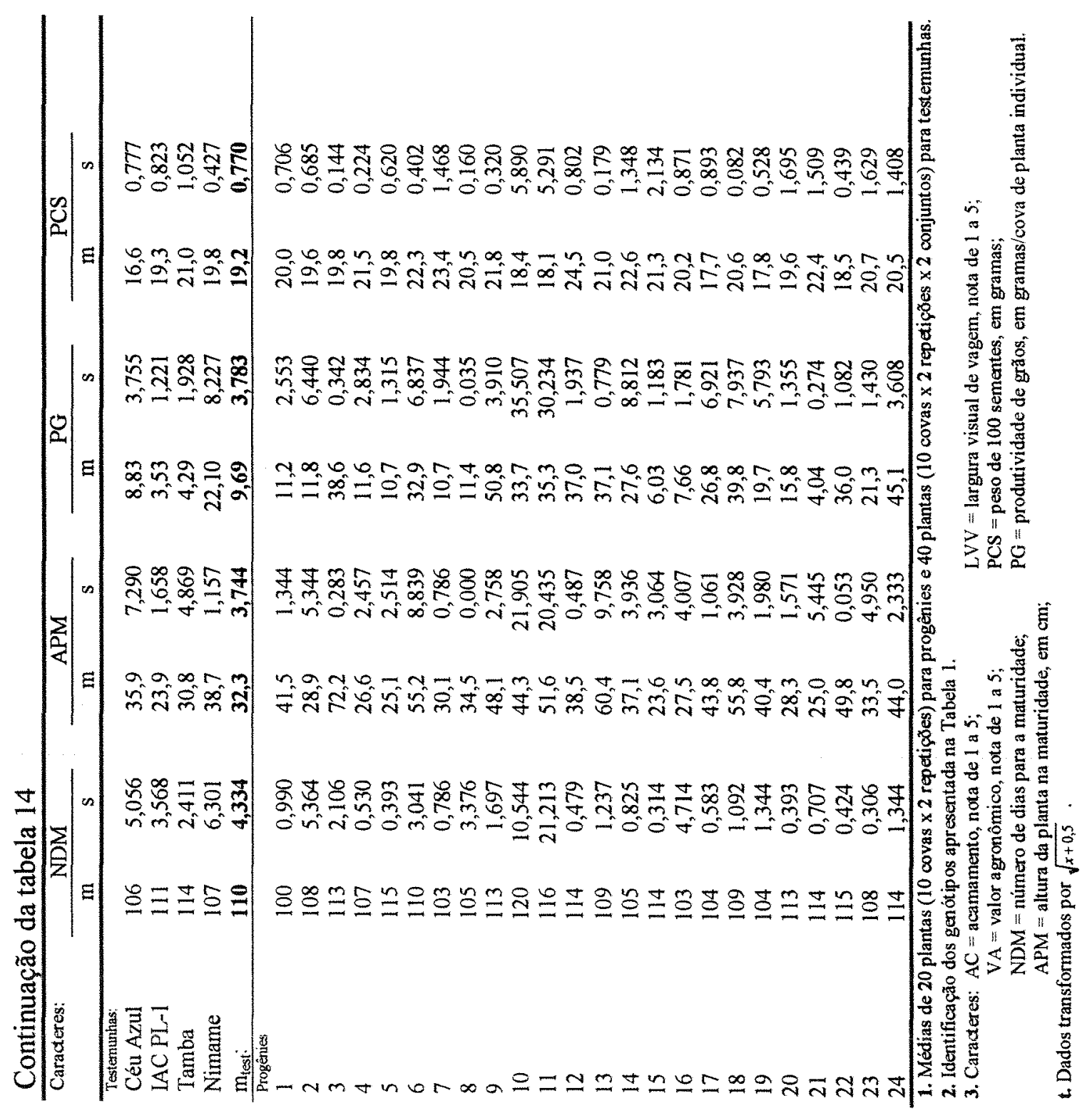




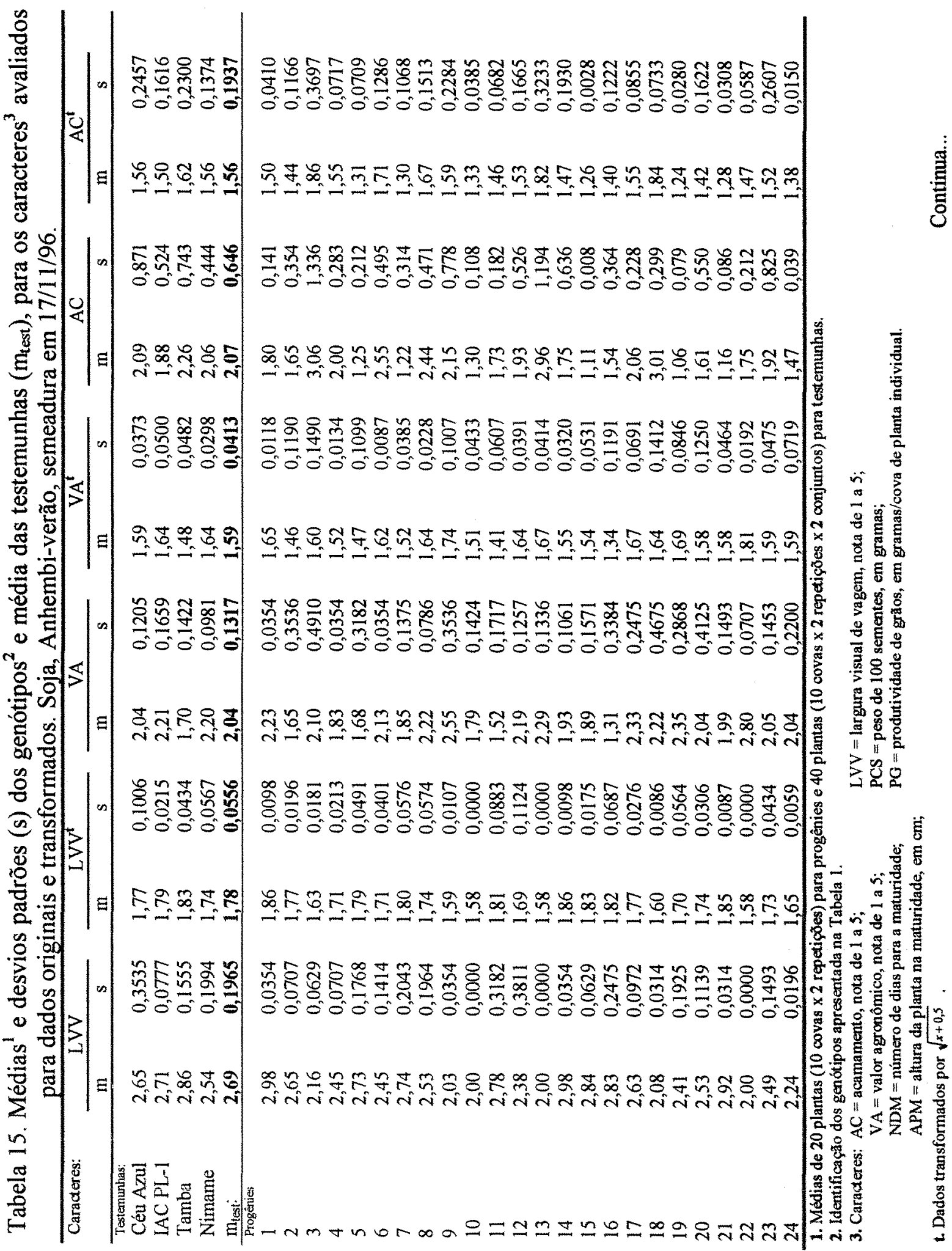




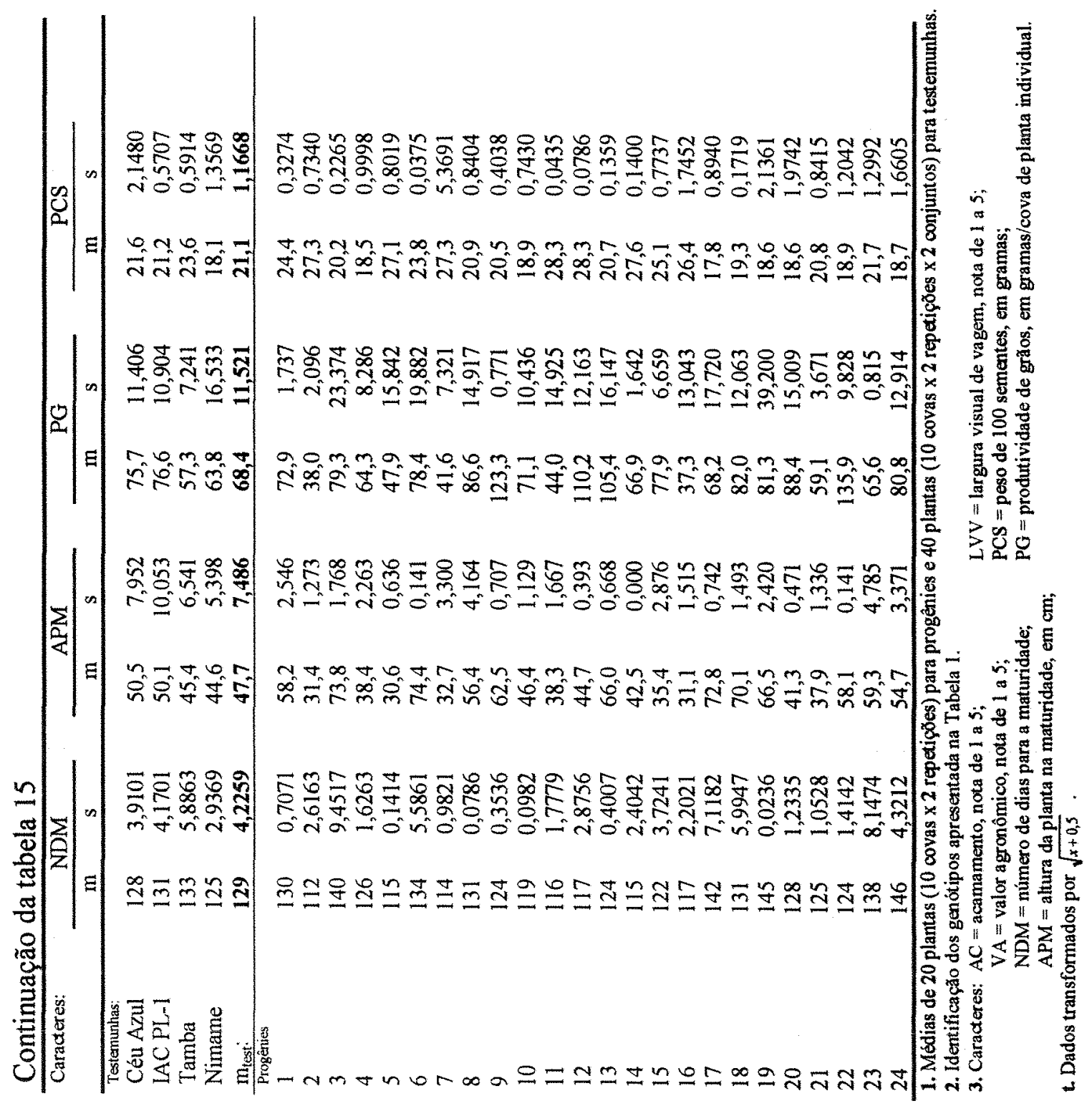









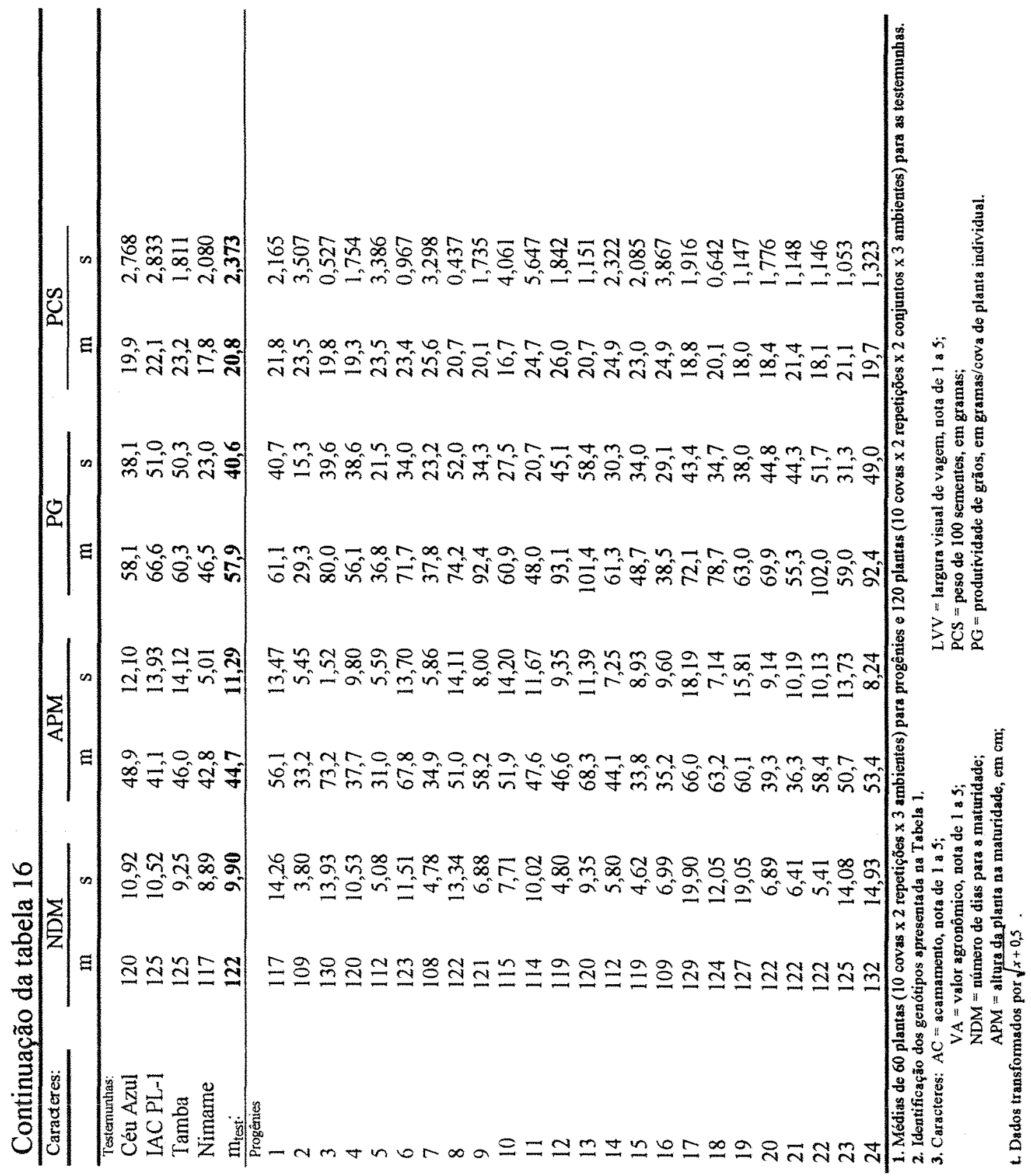




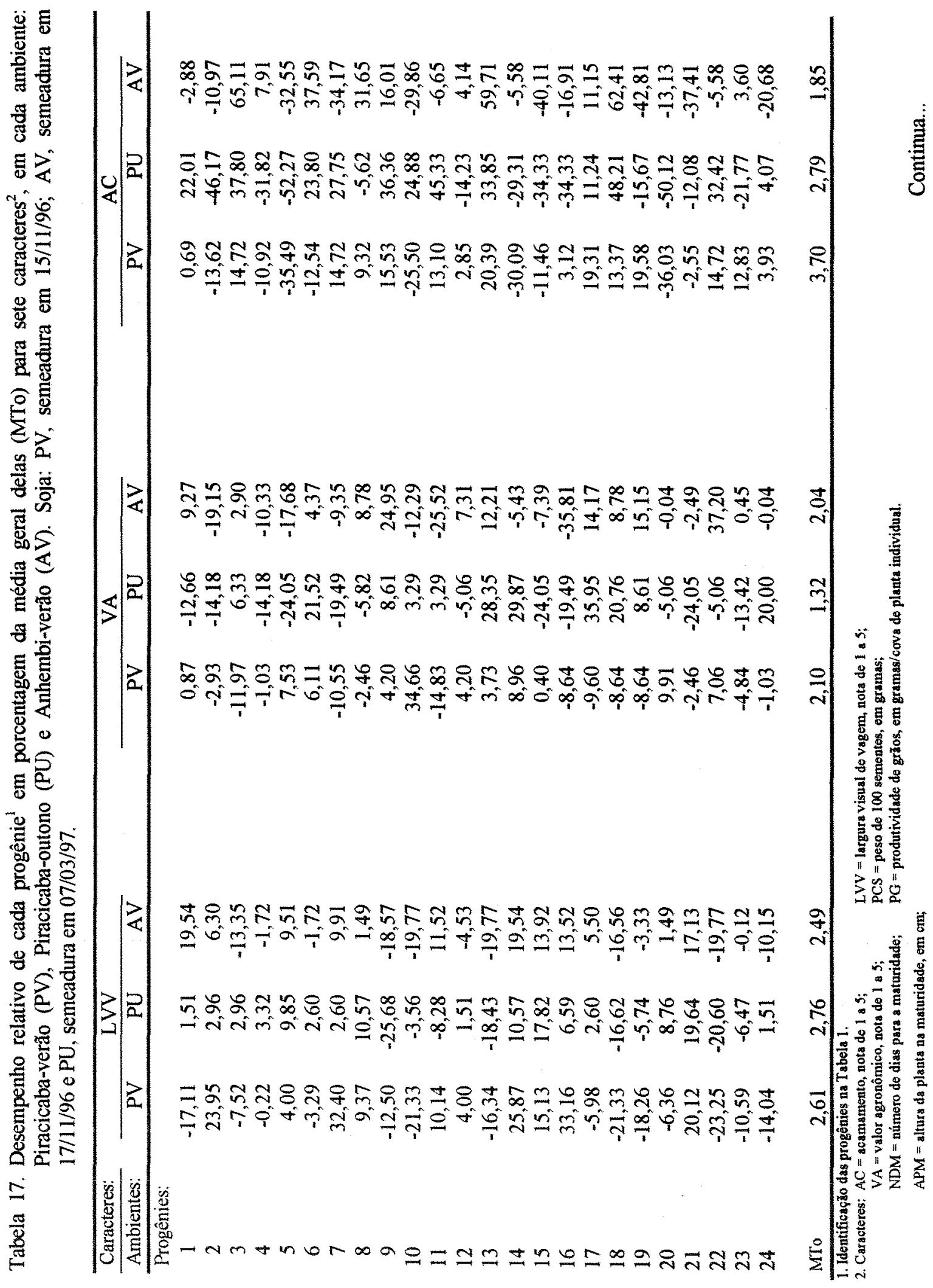




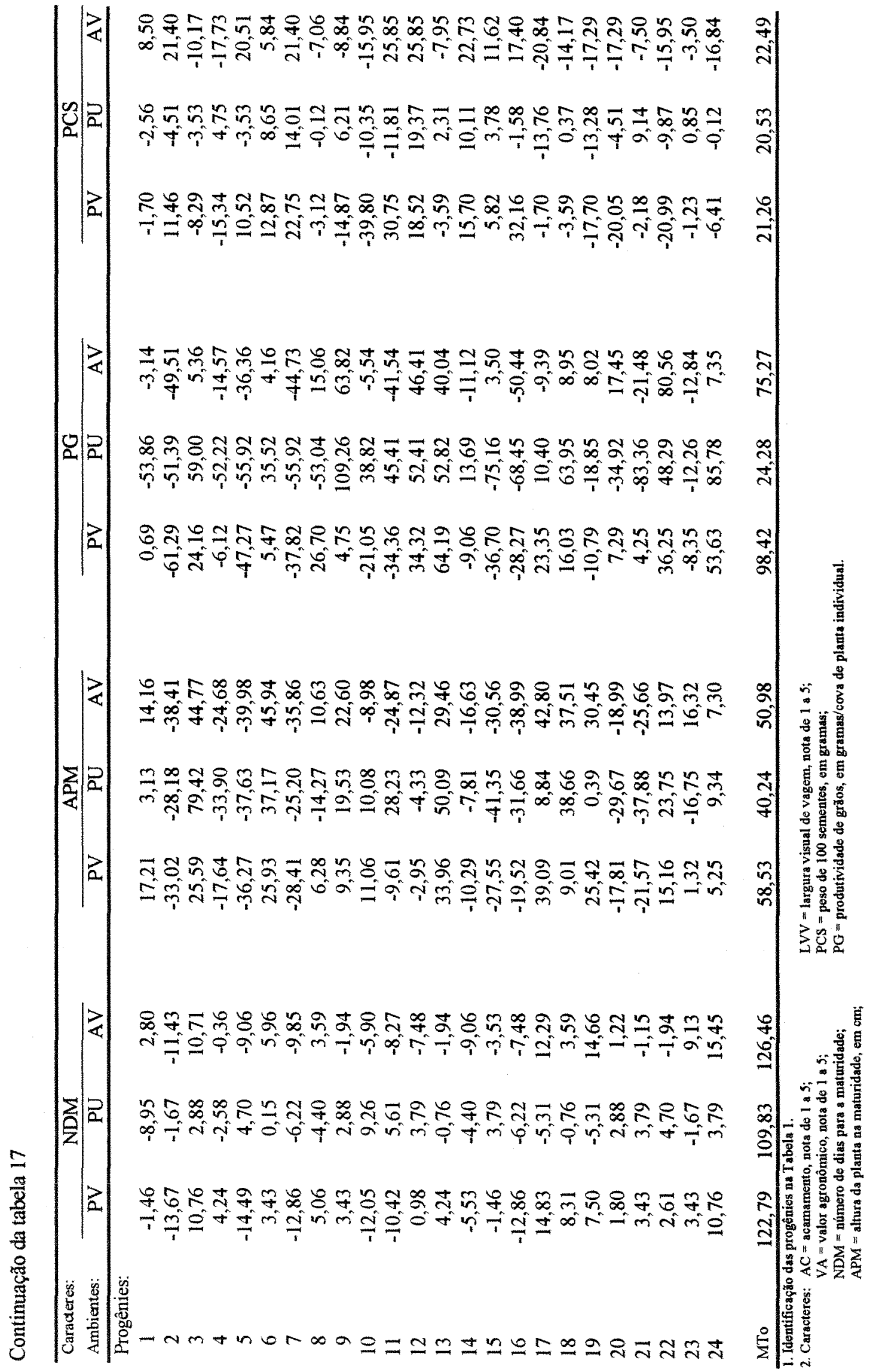




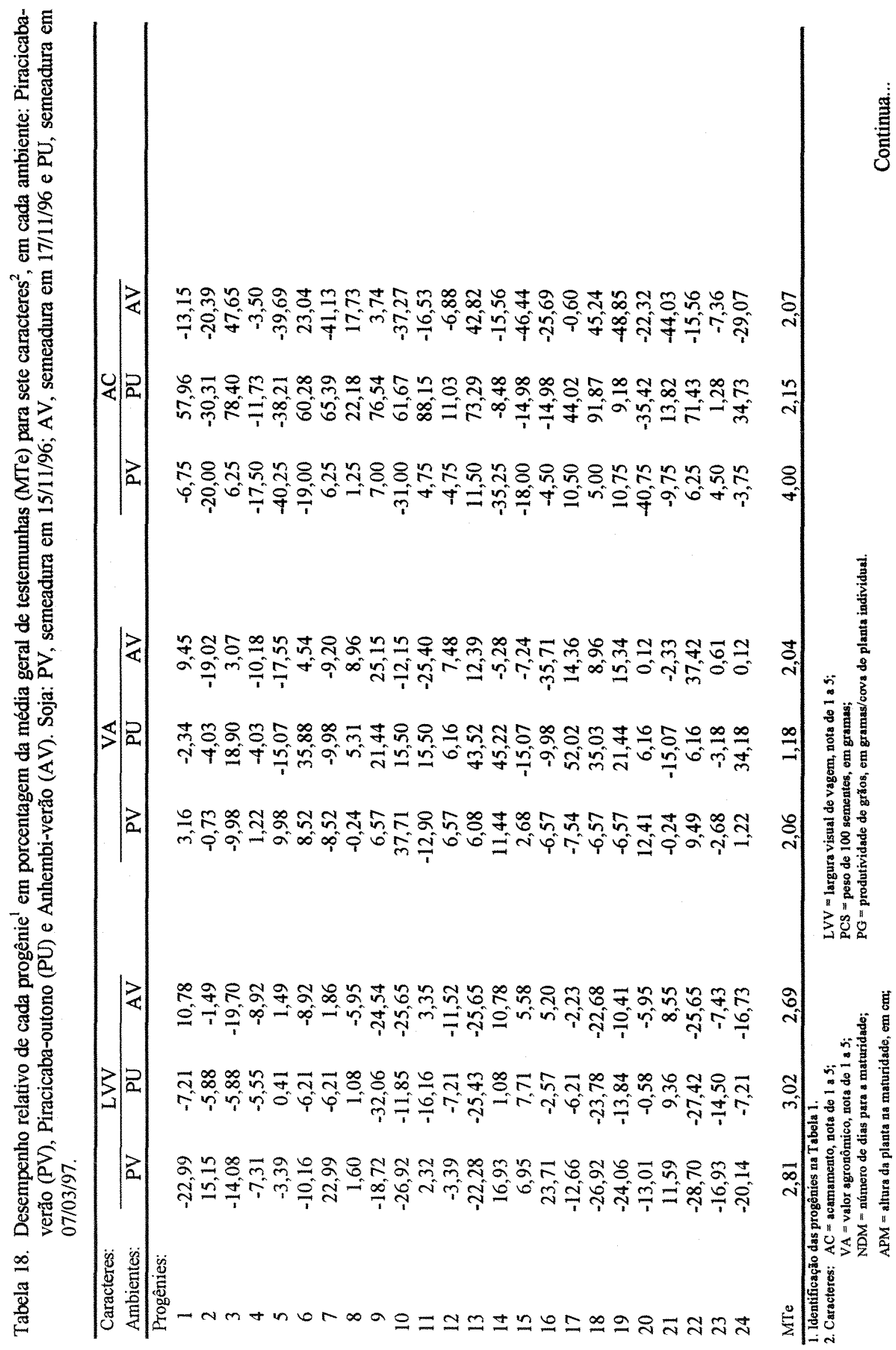




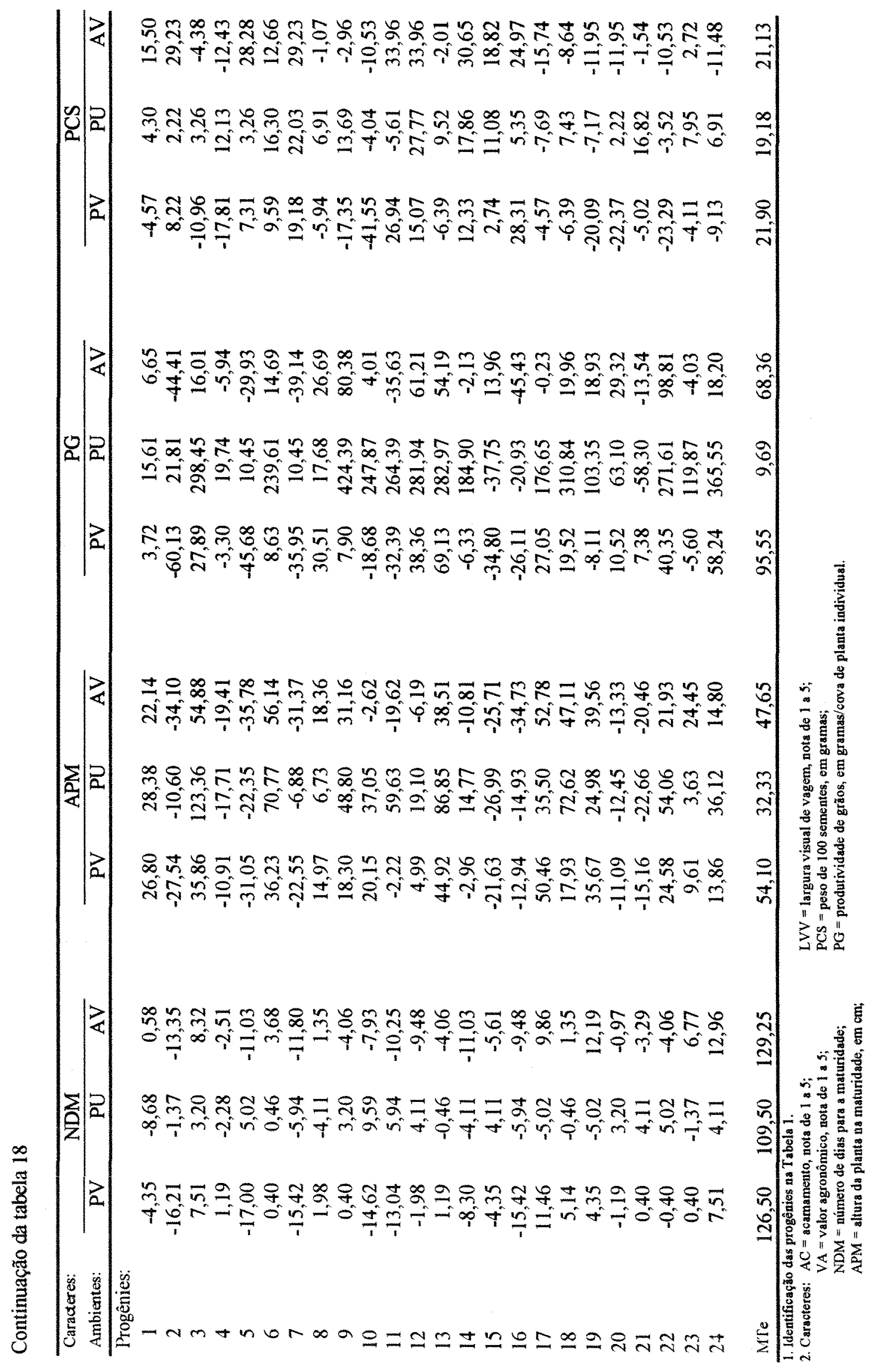




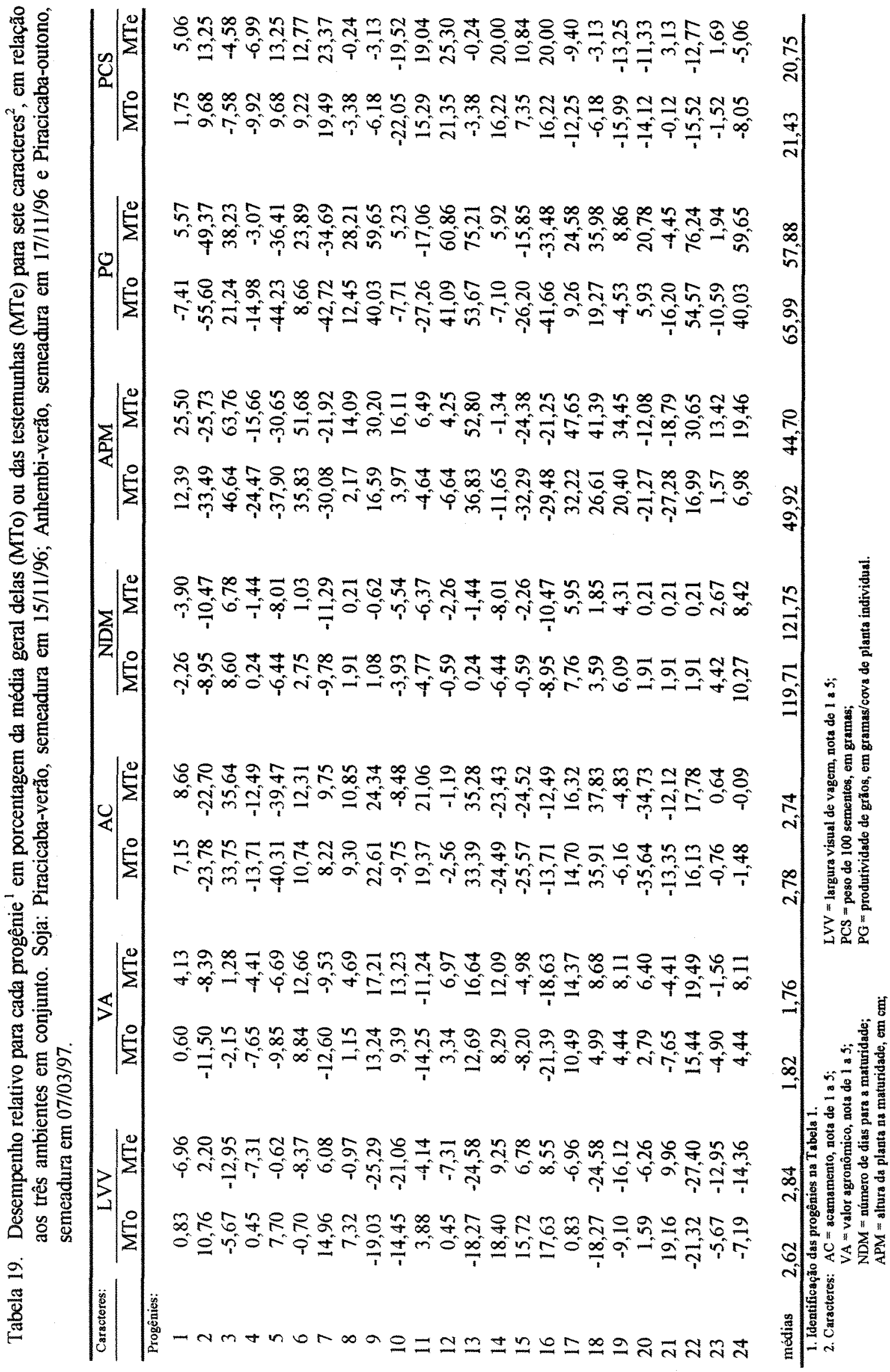




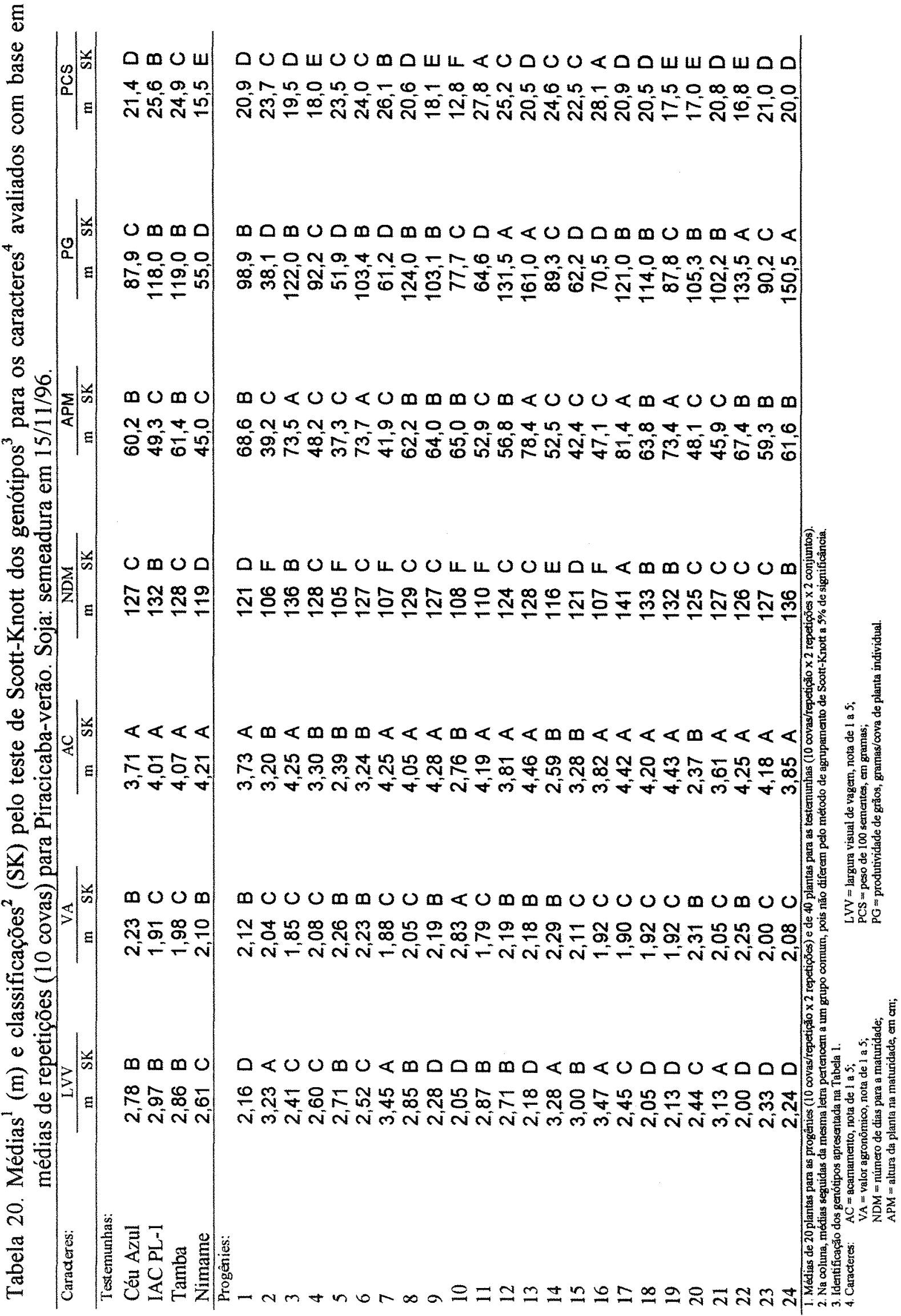




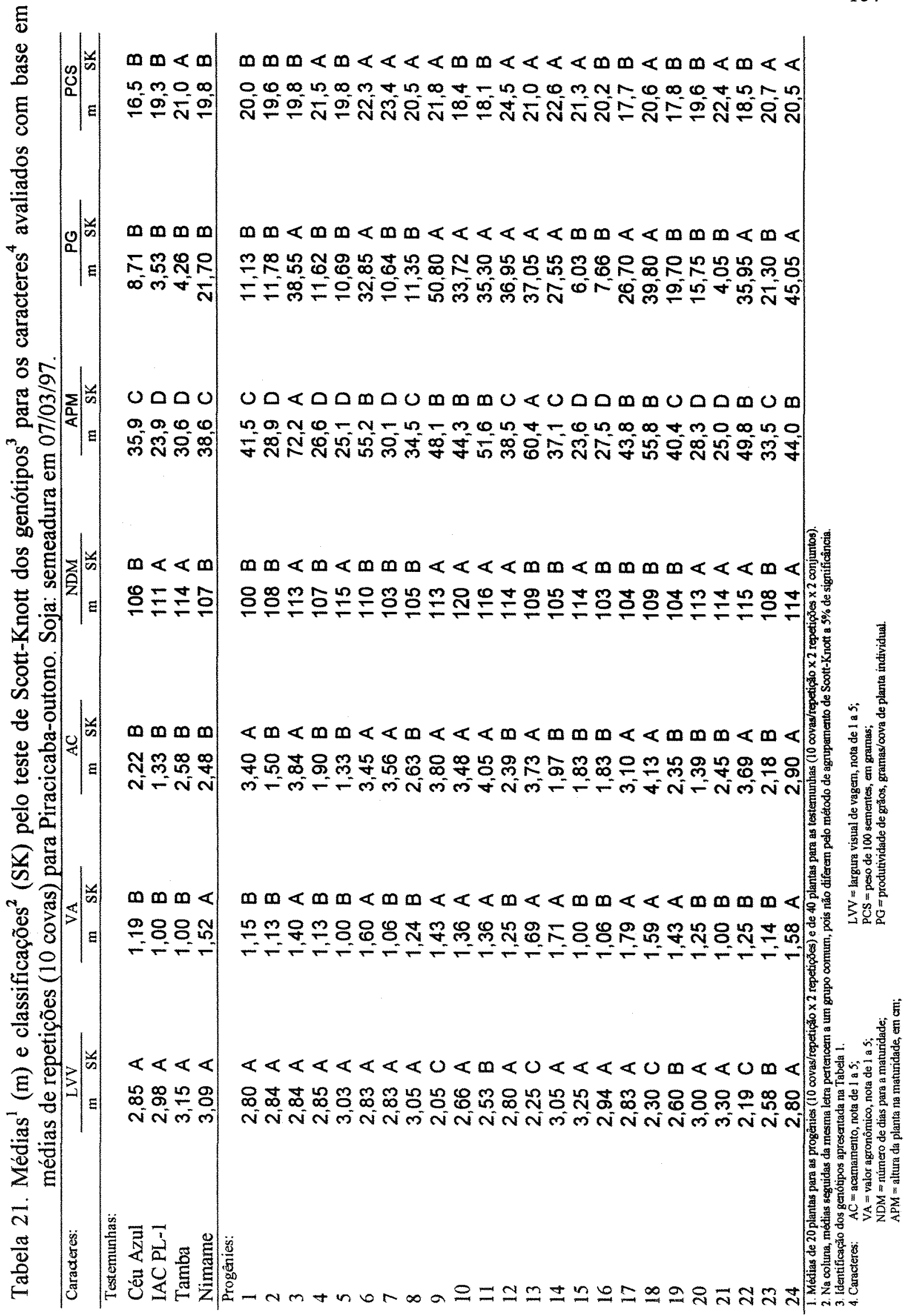


0000 nก⿻上丨 సั

m $\boldsymbol{\infty} \cup \boldsymbol{m}$ $0.0+\infty$ กำ

0000 $0=m \infty$ 员它 年

Om $m$ 品色 :

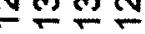

$<<<\varangle$ g N-ñ

$<<m<$ 붕도유 Niñ

$m<<m$ ๑゚下ゅ Nกัก
$m<00<m<U 00<<0<m<00000000$

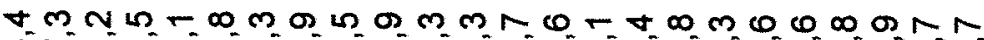

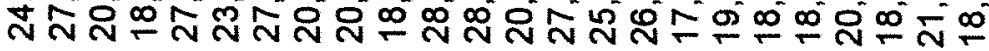

m U m

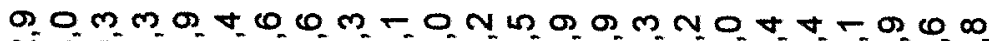
ำ

m $0<00<0$ m $000<000<<<00 m$ m

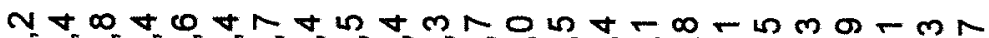

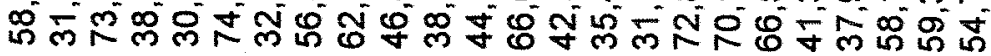

m

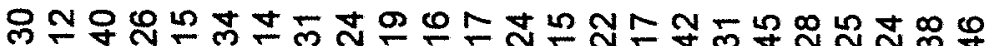

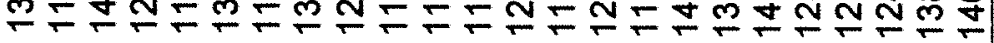

$<<<<<<<<<<<<<<<<<<<<<<<<$

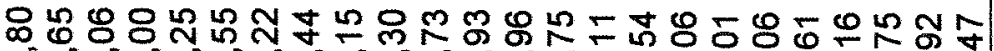

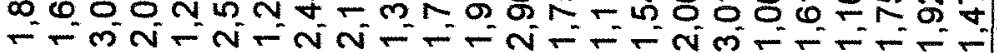

$<m<m m<m<<m m<<m m m<<<<<<<<$ ํㅛㅇㅇㅡ

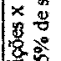
N-n

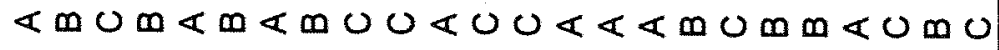

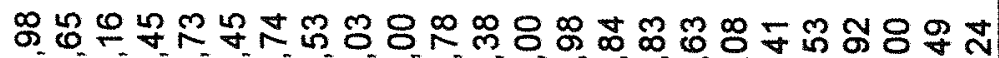

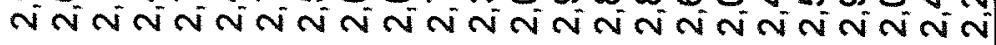




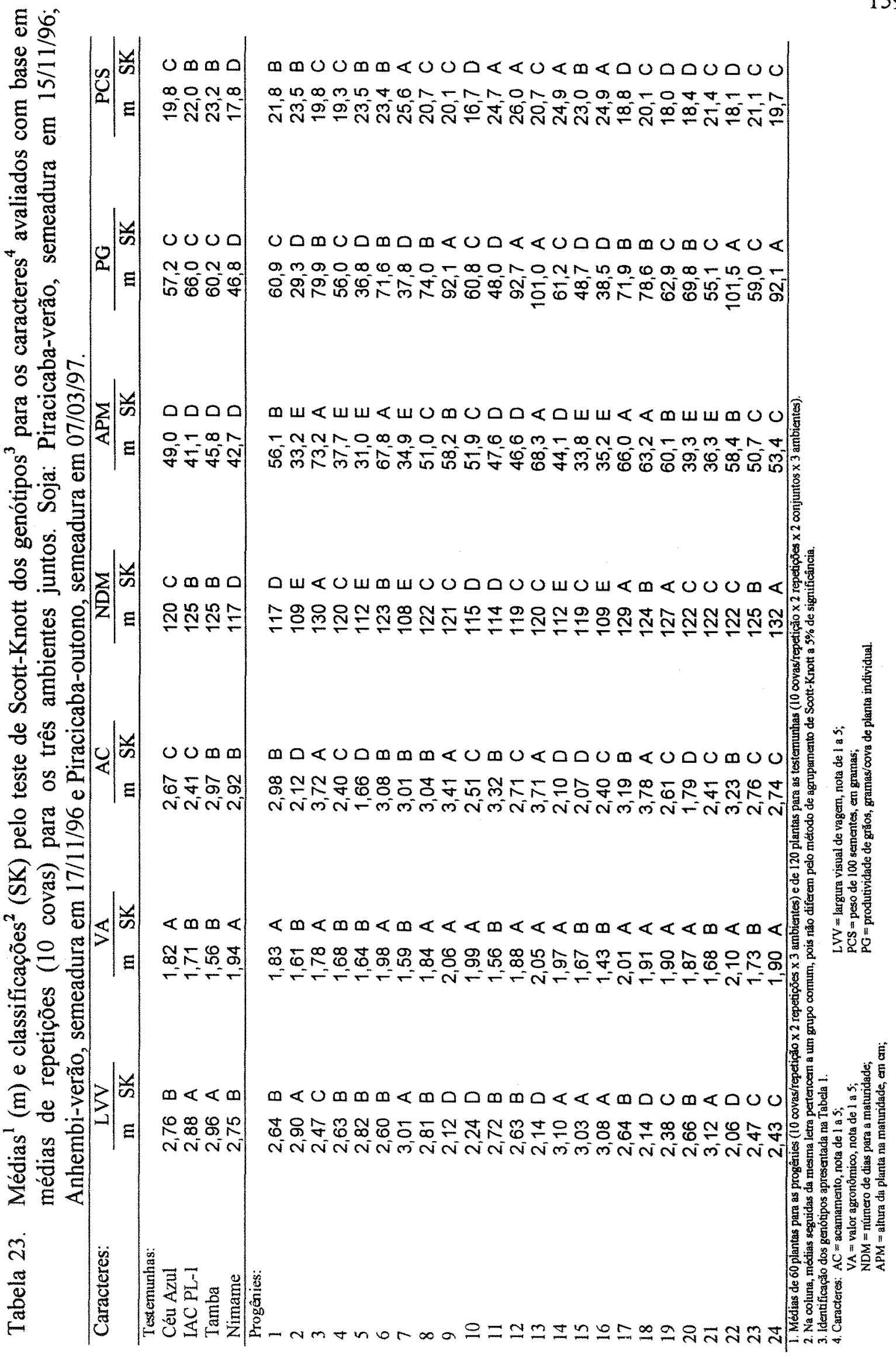


ㄴํㅇ 웅

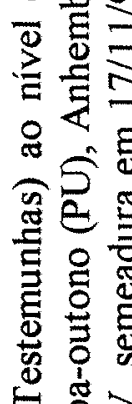

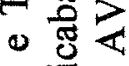

象它

言

象安药

है

을 윻

क力

芦颉

뭉

鲩文

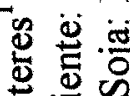

施

용

嘉

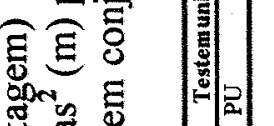

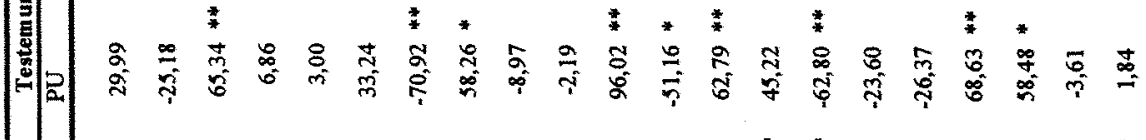

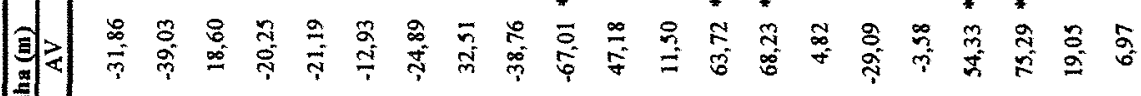

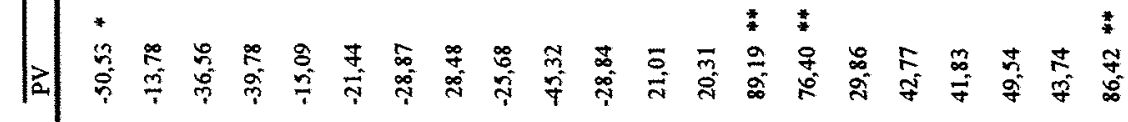

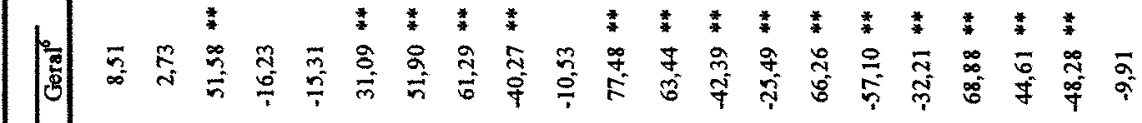

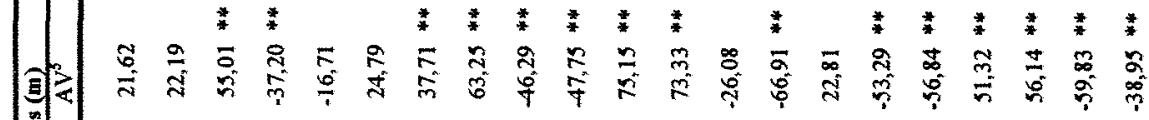

| 学

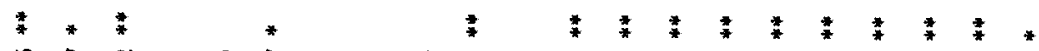

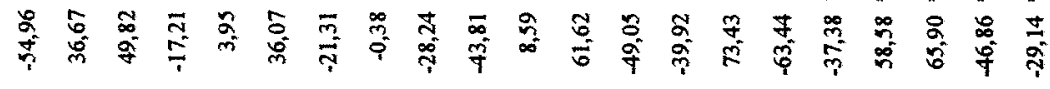

递要

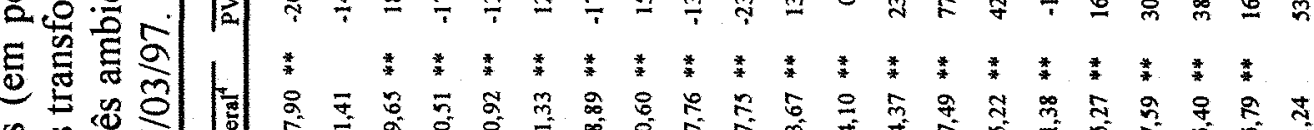

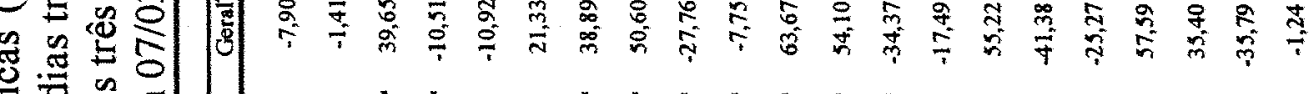

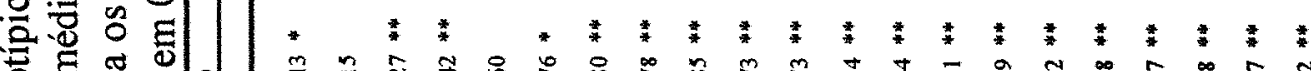

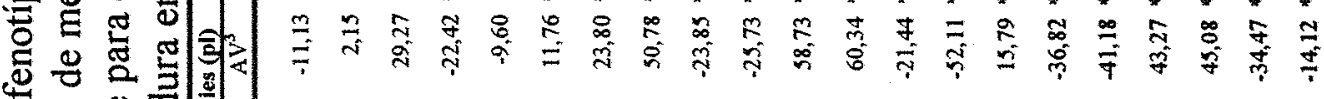

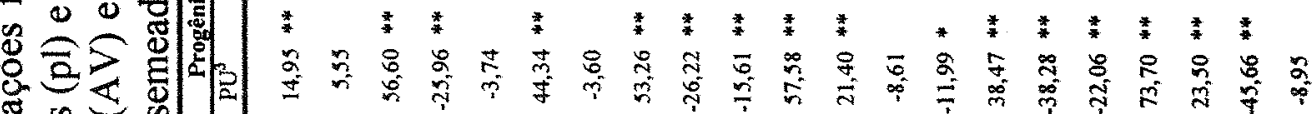

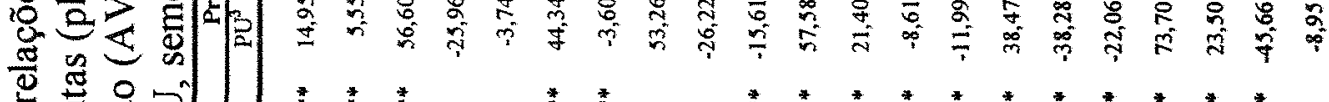

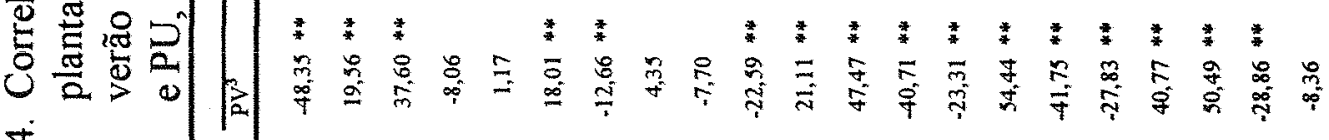
पं $\frac{\sqrt{2}}{\frac{0}{20}}$ 


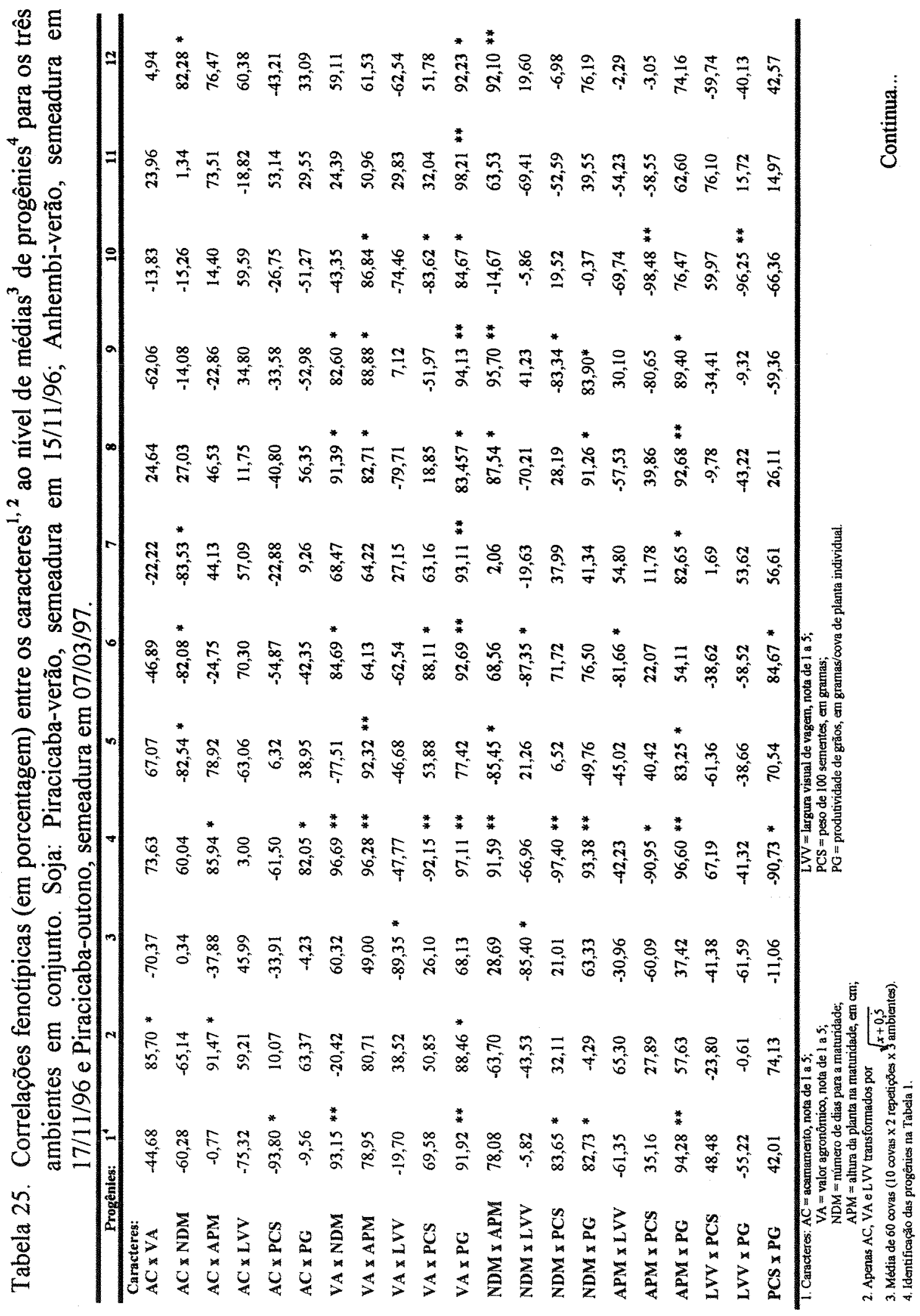




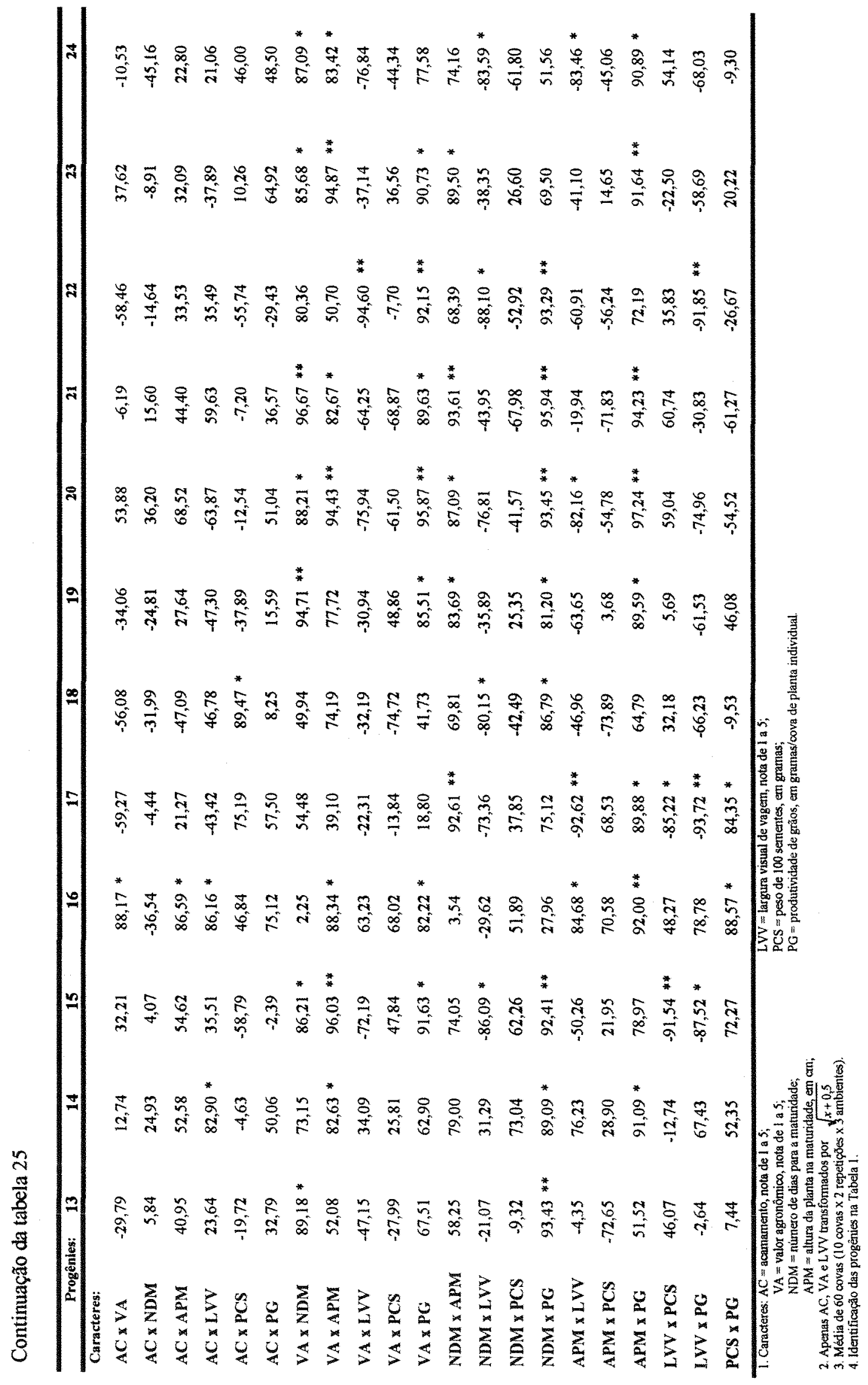


Tabela 26. Correlações genéticas entre os caracteres ${ }^{1}$ avaliados em Piracicaba-verão (PV), Piracicaba-outono (PU) e Anhembi-verão (AV) e para os três ambientes em conjunto (Geral). Soja: PV, semeadura em 15/11/96; AV, semeadura em 17/11/96 e PU, semeadura em 07/03/97.

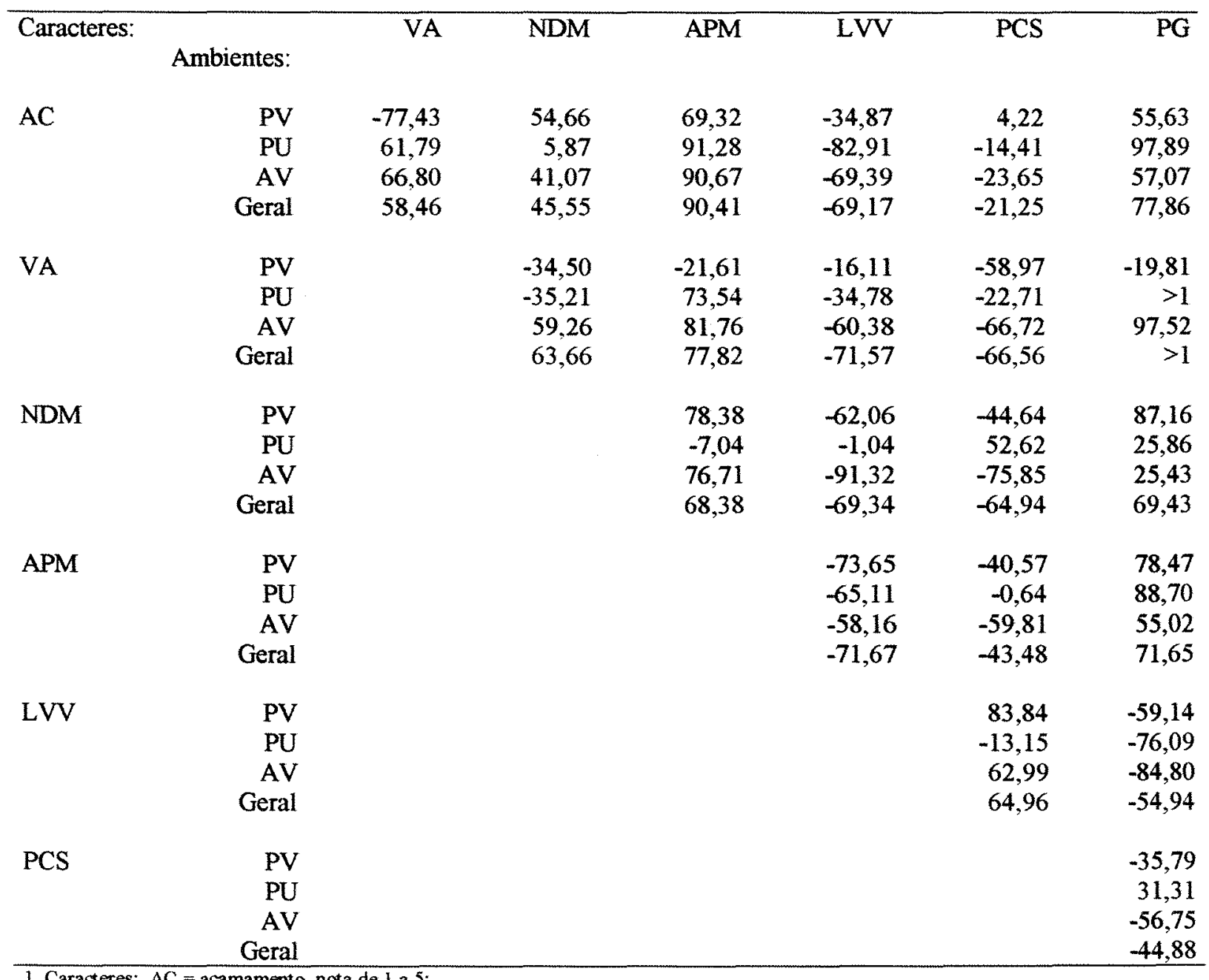

1. Caracteres: $\mathrm{AC}=$ acamamento, nota de 1 a 5 ;

$\mathrm{VA}=$ valor agronomico, nota de 1 a 5 ;

$\mathrm{NDM}=$ número de dias para a maturidade;

APM = altura da planta na maturidade, em cm;

$L V V=$ largura visual de vagem, nota de 1 a 5 ;

PCS = peso de 100 sementes, em gramas:

$\mathrm{PG}=$ produtividade de grãos, em gramas/cova de planta individual . 
Tabela 27. Diferenças entre as maiores e menores médias dentro dos grupos Progênies (Pro) e Testemunhas (Te) para os caracteres $\mathrm{NDM}^{1}, \mathrm{LVV}^{2}$ e $\mathrm{PCS}^{3}$ para os ambientes: Piracicaba-verão (PV), Piracicaba-outono (PU), Anhembi-verão (AV) e para os três ambientes em conjunto (Geral).

\begin{tabular}{|c|c|c|c|c|c|c|c|c|c|c|c|}
\hline \multirow{2}{*}{$\begin{array}{l}\text { Caracteres: } \\
\text { Ambientes: }\end{array}$} & \multicolumn{3}{|c|}{ LVV } & \multicolumn{4}{|c|}{ NDM } & \multicolumn{4}{|c|}{ PCS } \\
\hline & PV & $\mathbf{P U}$ & $\overline{\mathbf{A V}}$ & PV & $\mathbf{P U}$ & $\mathbf{A V}$ & Geral & $\overline{\mathbf{P V}}$ & $\mathbf{P U}$ & $\mathbf{A V}$ & Geral \\
\hline \multicolumn{12}{|l|}{ Grupos: } \\
\hline Pro & 0,41 & 0,35 & 0,28 & 31 & 20 & 34 & 24 & 15,3 & 6,7 & 10,5 & 9,3 \\
\hline Te & 0,10 & 0,08 & 0,09 & 13 & 8 & 8 & 8 & 10,1 & 4,4 & 5,5 & 5,4 \\
\hline
\end{tabular}

1. NDM: número de dias para a maturidade,

2. LVV: largura visual de vagem, nota de 1 à 5 ;

3. PCS: peso de cem sementes, en gramas.

Tabela 28. Diferenças entre a maior e a menor média $(\mathrm{m})$ obtida entre as progênies para os caracteres acamamento (AC), valor agronômico (VA) e largura visual de vagem (LVV) para Piracicaba-verão (PV), Anhembi-verão (AV) e Piracicaba-outono (PU). Soja: PV, semeadura em 15/11/96; AV, semeadura em 17/11/96 e PU, semeadura em 07/03/97.

\begin{tabular}{|c|c|c|c|c|c|c|c|c|c|}
\hline \multirow{2}{*}{$\begin{array}{l}\text { Caracteres: } \\
\text { Ambientes: }\end{array}$} & \multicolumn{3}{|c|}{$\mathbf{A C}$} & \multicolumn{3}{|c|}{ VA } & \multicolumn{3}{|c|}{ LVV } \\
\hline & PV & $\mathbf{A V}$ & PU & PV & $\mathbf{A V}$ & PU & PV & $\mathbf{A V}$ & PU \\
\hline \multicolumn{10}{|l|}{ médias: } \\
\hline Maior & 2,22 & 1,86 & 2,14 & 1,82 & 1,81 & 1,51 & 1,99 & 1,86 & 1,95 \\
\hline Menor & 1,66 & 1,24 & 1,32 & 1,51 & 1,34 & 1,22 & 1,58 & 1,58 & 1,60 \\
\hline Diferença: & 0,56 & 0,62 & 0,82 & 0,31 & 0,47 & 0,29 & 0,41 & 0,28 & 0,35 \\
\hline
\end{tabular}




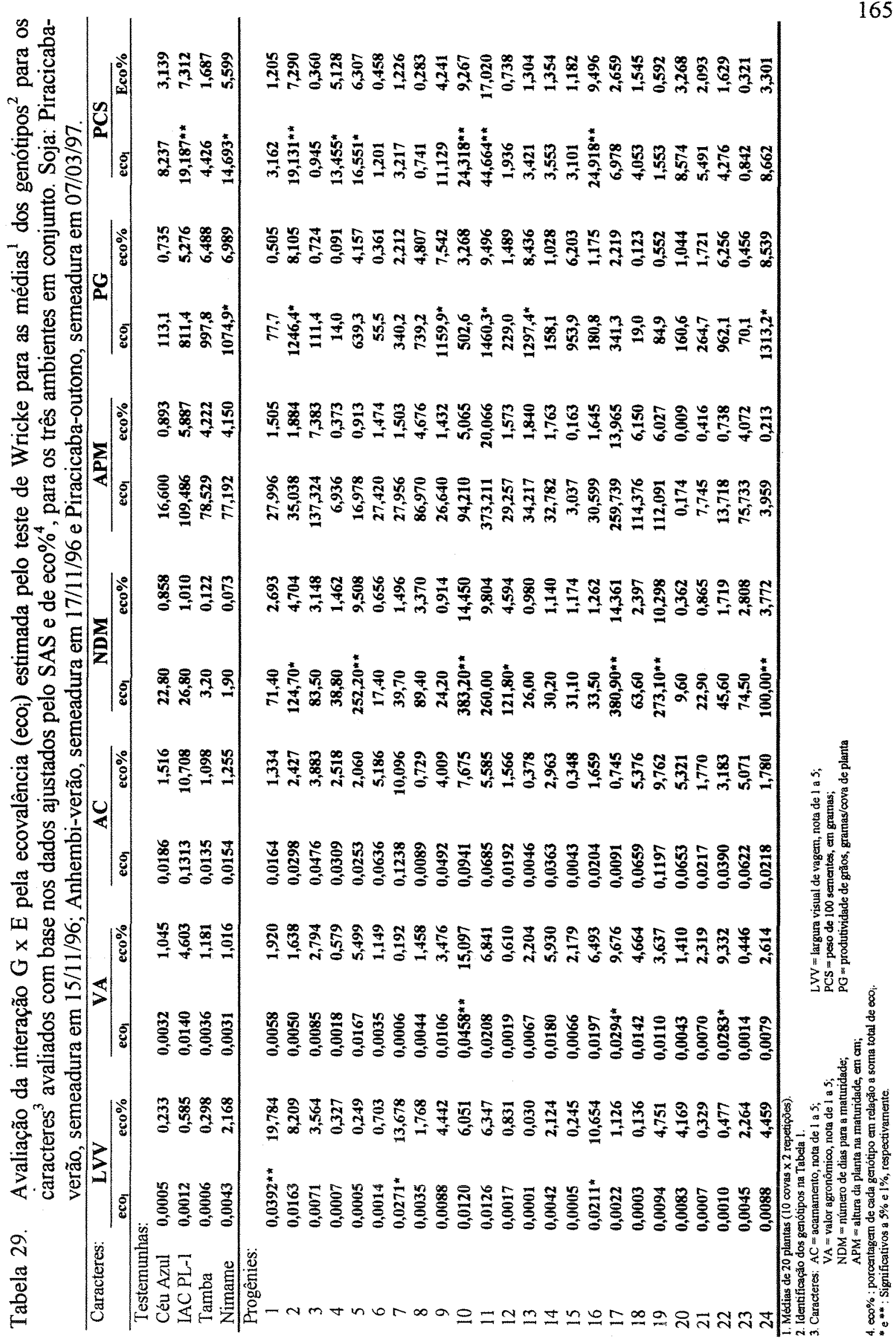




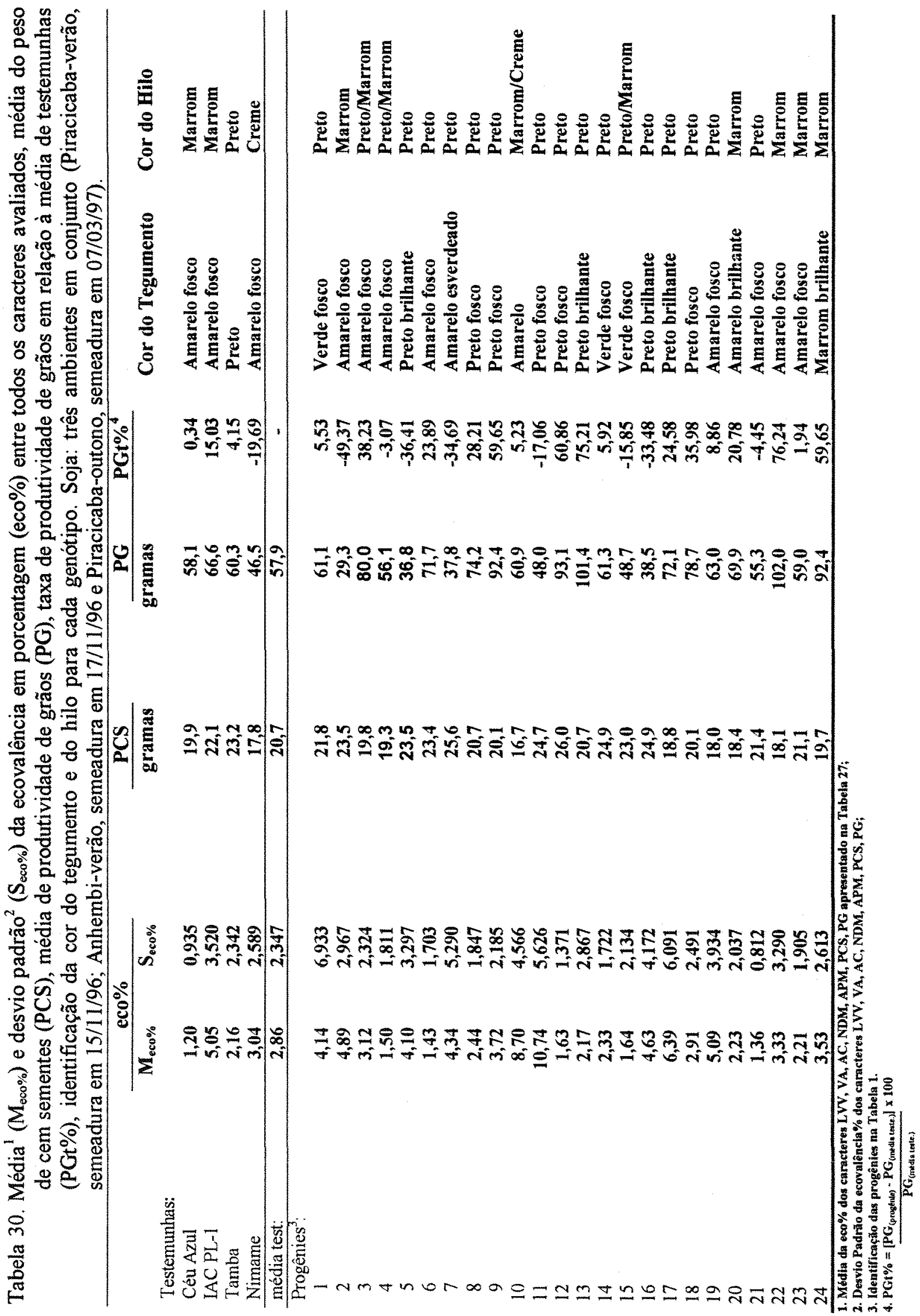


Figura 1. Histogramas apresentando a frequência ${ }^{1}$ dos grupos (A, B, e demais grupos) de classificação de Scott-Knott para os genótipos ${ }^{2}$ em relação aos caracteres: produtividade de grãos (PG), peso de cem sementes (PCS) e valor agronômico (VA). Soja: considerando as análises individuais para cada ambiente: Piracicaba-verão (PV), Piracicaba-outono (PU) e Anhembi-verão (AV).

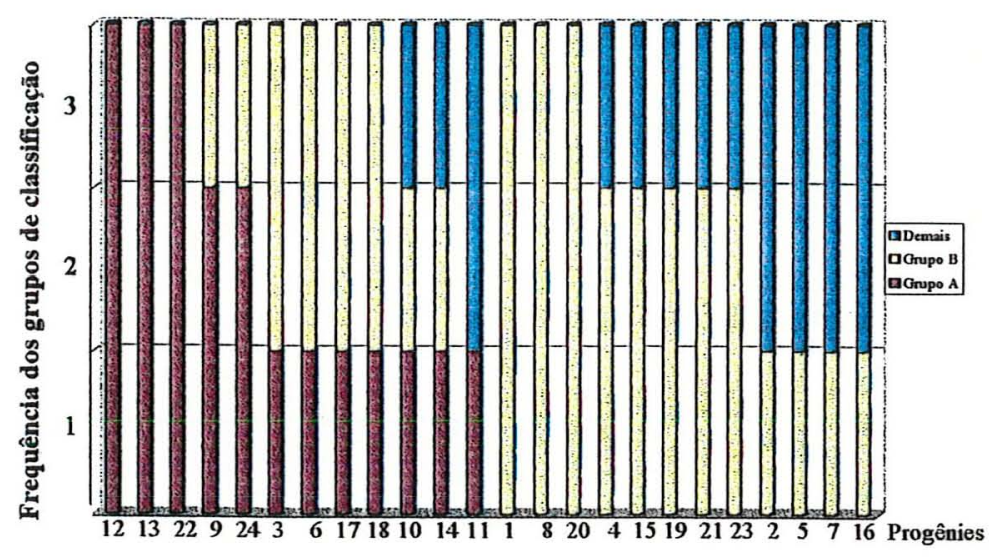

PG

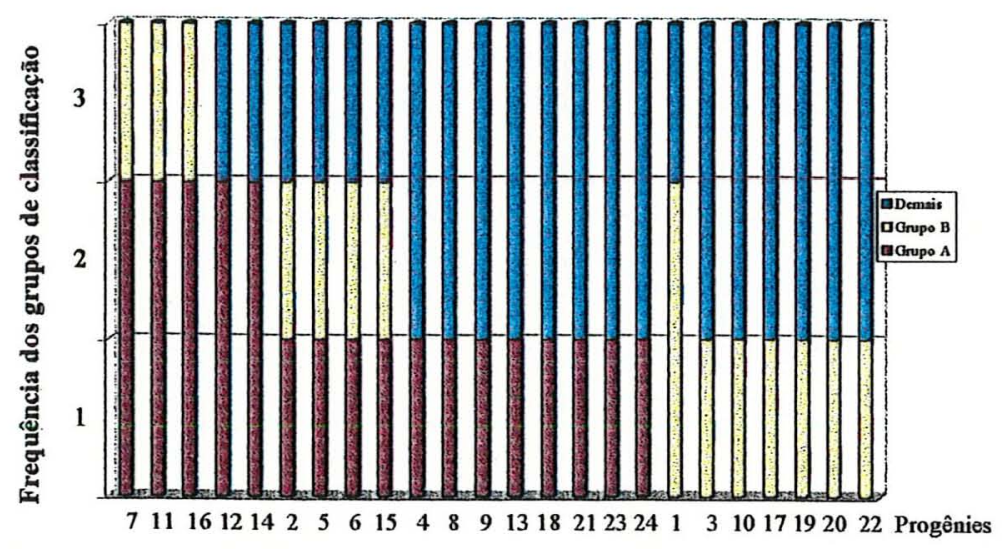

PCS

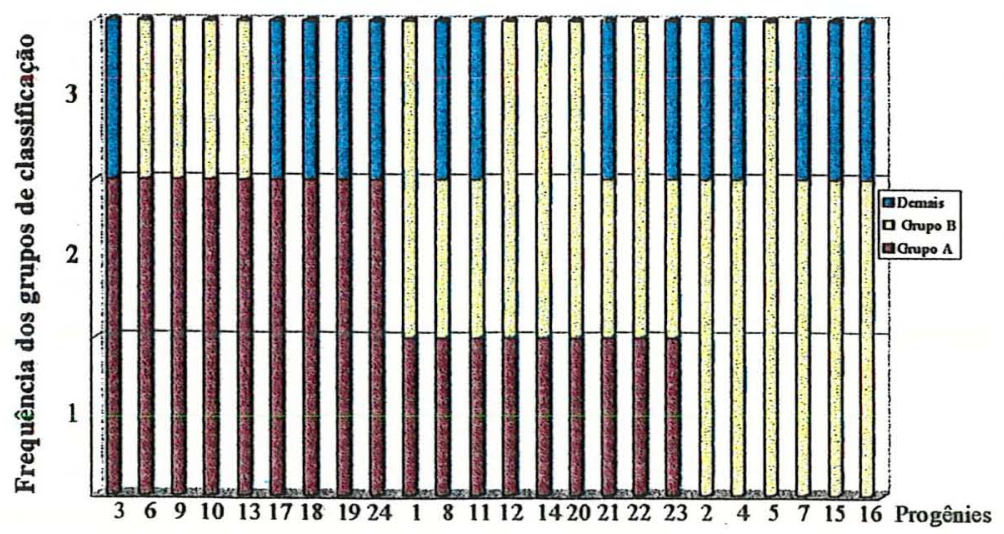

VA

1. Número de vezes em que a progênie foi classificada em cada grupo na análise de Scott-Knott para cada ambiente individualmente, a sequência da frequência independe da ordern dos ambientes PV, AV e PU.

2. Identificação das progênies é apresentada na Tabela 1. 
Figura 2. Gráfico de caixa ("Box plot") para os caracteres ${ }^{1}$ avaliados empregando-se as médias $^{2}$ dos dados originais para cada ambiente individual, Piracicaba-verão (PV), Piracicaba-outono (PU) e Anhembi-verão (AV). Soja: PV, semeadura em. 15/11/96; AV, semeadura em 17/11/96 e PU, semeadura em 07/03/97.

LVV

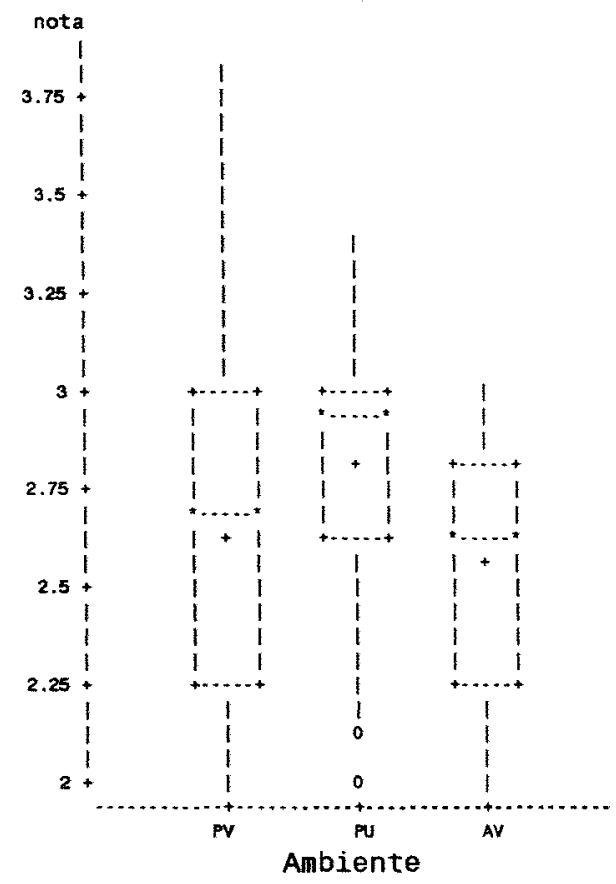

AC

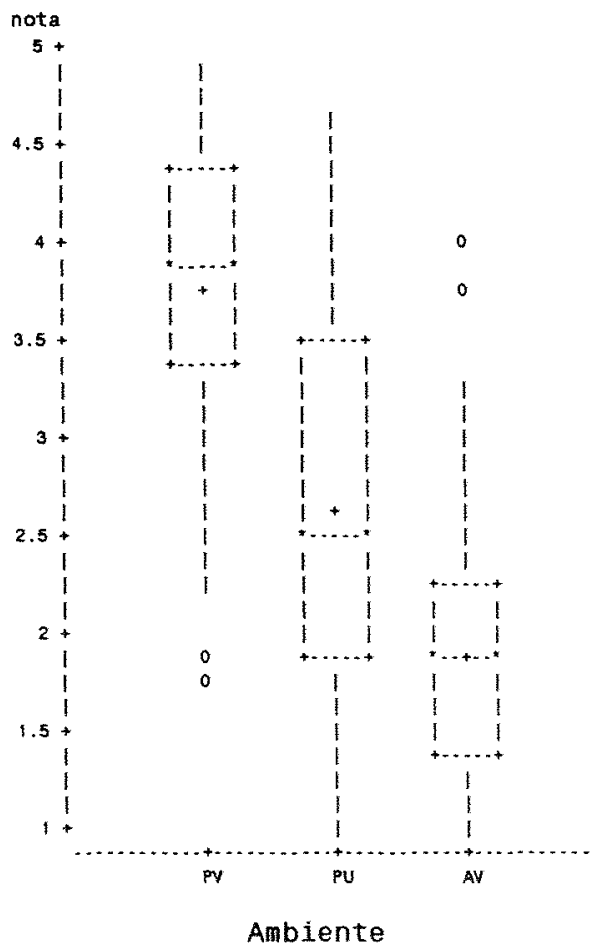

VA

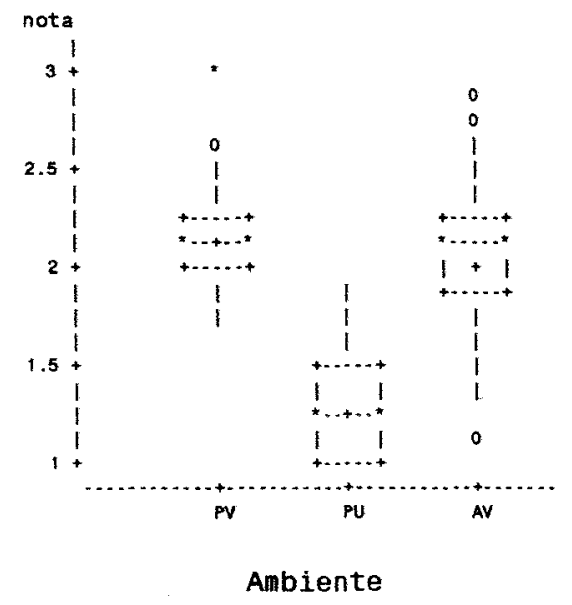

NDM

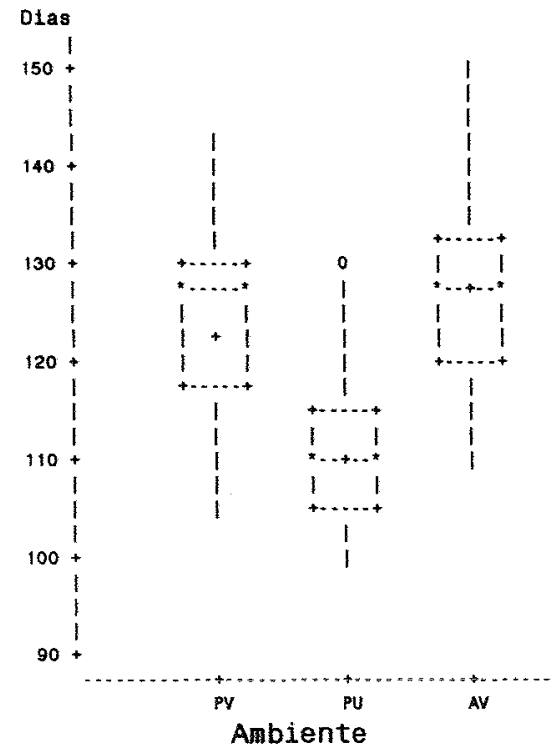

Continua... 
Figura 2 - continuação
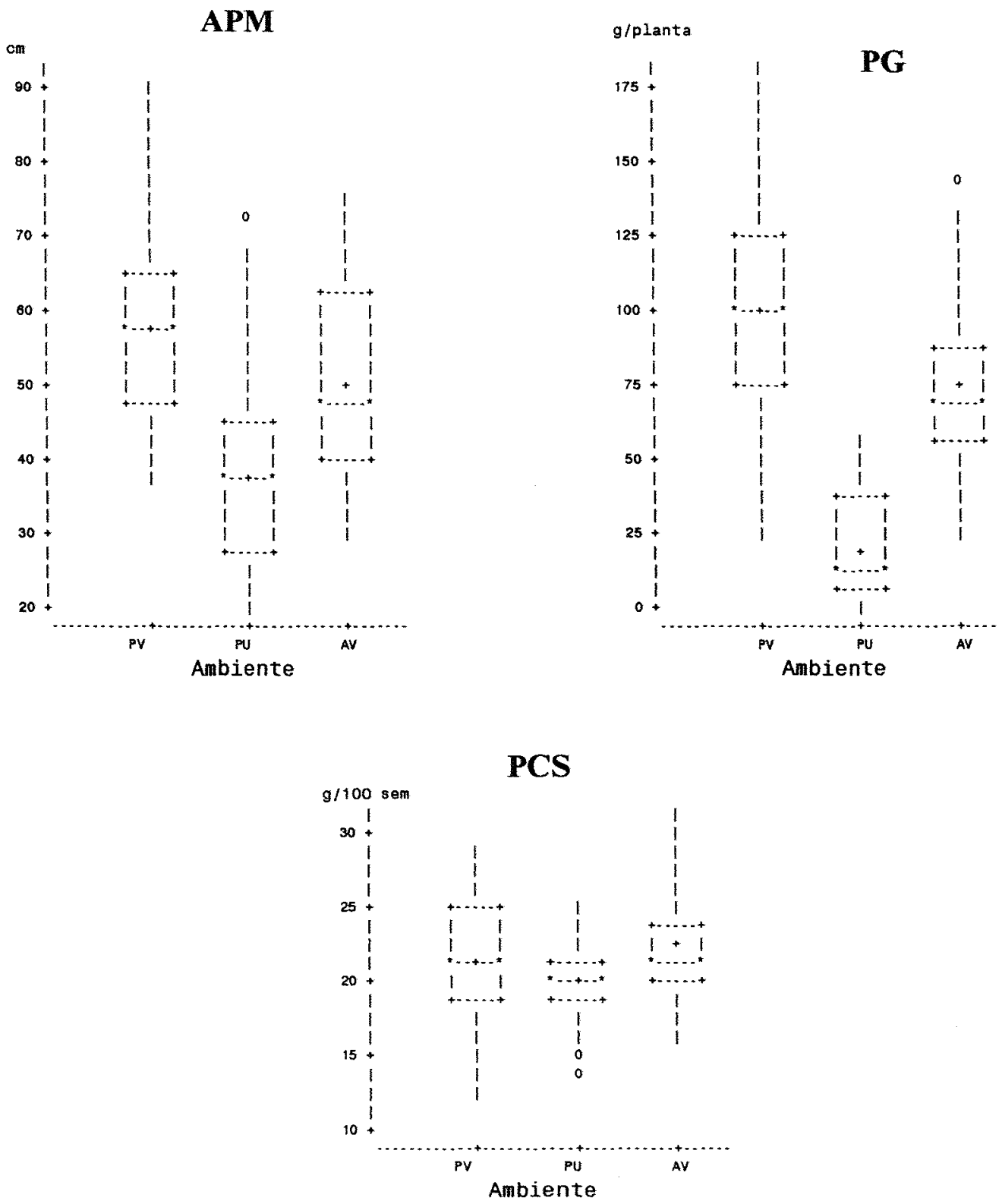

1. Caracteres: $\mathrm{AC}=$ acamamento, nota de 1 a 5;

$\mathrm{VA}=$ valor agronômico, nota de 1 a 5 .

NDM = número de dias para a maturidade;

$A P M=$ altura da planta na maturidade, $\mathrm{em} \mathrm{cm}$;

LVV = largura visual de vagem, nota de 1 a 5 ;

$\mathrm{PCS}=$ peso de 100 sementes, em gramas;

$P G=$ produtividade de grãos, em gramas/cova de planta individual.

2. Médias de 20 plantas ( 10 covas $\times 2$ repetições). 
APÊNDICE 
Apêndice 1. Escala de notas visuais aplicado sobre a largura visual das vagens (LVV) de soja.
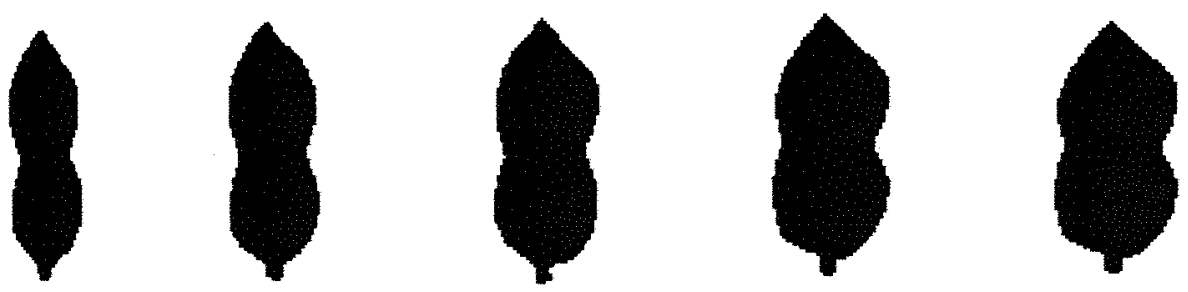

Notas Visuais: 1 3 4 5

Largura: $\quad 8,0-8,5 \quad 8,6-9,5 \quad 9,6-10,5 \quad 10,6-11,5 \quad>11,6 \mathrm{~mm}$

